LEGAL NOTICE

This report was prepared as an account of work sponsored by the United States Government. Neither the United States nor the United States Atomic Energy Commission, nor any of their employees, nor any of their contractors, subcontractors, or their employees, makes any warranty, express or implied, or assumes any legal liability or responsibility for the accuracy, completeness or usefulness of any information, apparatus, product or process disclosed, or represents that its use would not infringe privately owned rights.
LMEC-70-10

General, Miscellaneous, and Progress Reports

\title{
Friction and Wear Screening Tests of Materials in Sodium
}

By

N. J. Hoffman

D. E. Goggin

J. J. Droher

\section{Liquid Metal Engineering Center}

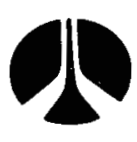

Operated for

the U.S. Atomic Energy Commission by Atomics International

\author{
A Division of Nortl American Rockwell Corporation
}

This document is

Contract: AT(04-3)-700

PUBLICLY RELEASABLE

B Steele
Authorizing Official
Date: $5-23-06$

Issued: JUL 151970 


\section{DISCLAIMER}

This report was prepared as an account of work sponsored by an agency of the United States Government. Neither the United States Government nor any agency Thereof, nor any of their employees, makes any warranty, express or implied, or assumes any legal liability or responsibility for the accuracy, completeness, or usefulness of any information, apparatus, product, or process disclosed, or represents that its use would not infringe privately owned rights. Reference herein to any specific commercial product, process, or service by trade name, trademark, manufacturer, or otherwise does not necessarily constitute or imply its endorsement, recommendation, or favoring by the United States Government or any agency thereof. The views and opinions of authors expressed herein do not necessarily state or reflect those of the United States Government or any agency thereof. 


\section{DISCLAIMER}

Portions of this document may be illegible in electronic image products. Images are produced from the best available original document. 


\section{DISTRIBUTION}

This report has been distributed according to the category

"General, Miscellaneous, and Progress Reports" as given

"Standard Distribution Lists for Unclassified Scientific and Technical Reports, "TID-4500.

\section{ACKNOWLEDGEMENT}

Of the many staff members of the Liquid Metal Engineering Center, who contributed to this effort; particular thanks are extended to: J. K. Balkwill, J. H. Brindley, K. E. Bozzo, W. J. Freede, M. M. French, and R. S. Kennedy. 


\begin{abstract}
The results of a number of screening tests on the friction and wear behavior of materials in contact within a sodium environment are presented and interpreted. The report is divided into two sections: (1) considerations for the designer, and (2) experimental material screening and analytical studies. The bulk of the data concerns the wear coefficient and coefficient of sliding friction at 900 or $1200^{\circ} \mathrm{F}$ in sodium fluid. Results from studies of coefficient of static friction and self-welding characteristics are also discussed.
\end{abstract}




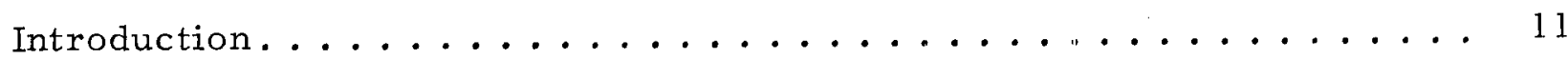

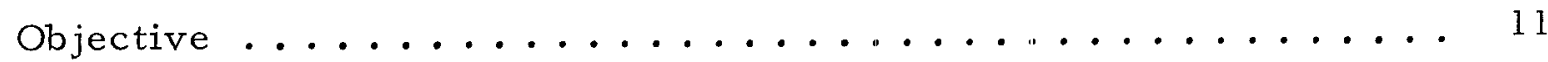

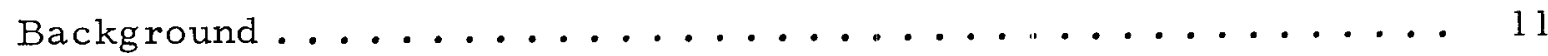

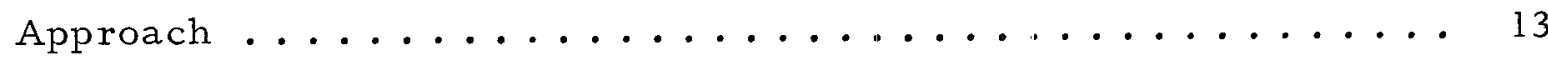

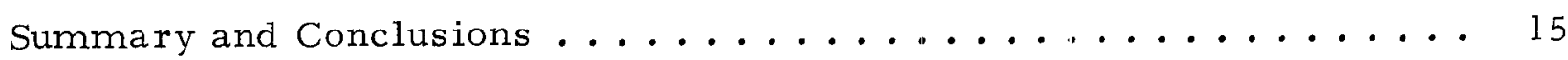

PART 1. CONSIDERATIONS FOR THE DESIGNER

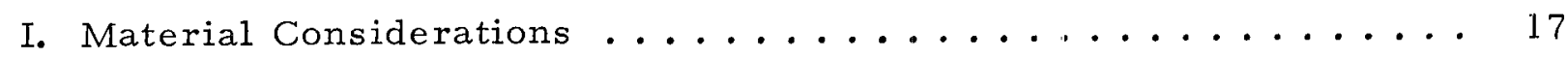

A. Required Material Characteristics. .............. 17

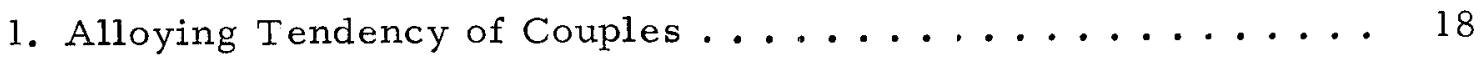

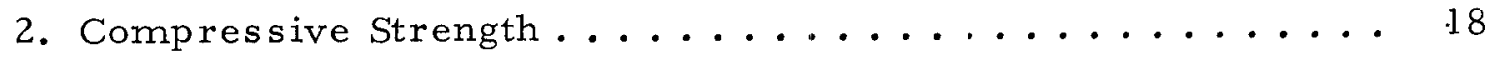

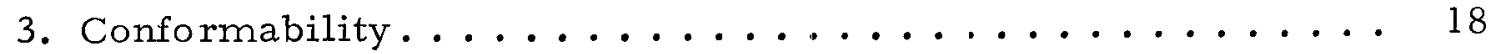

4. Corrosion Resistance ...................... 19

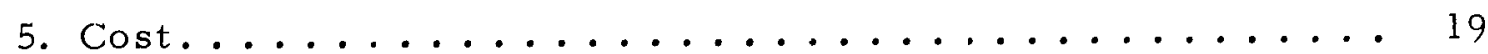

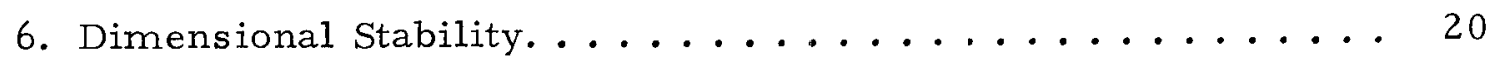

7. Ductility and Impact Strength ............... 20

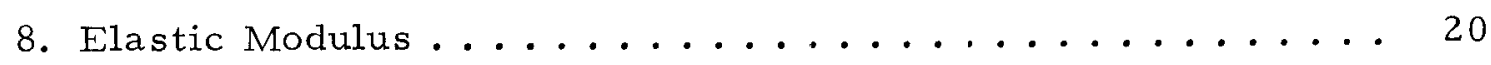

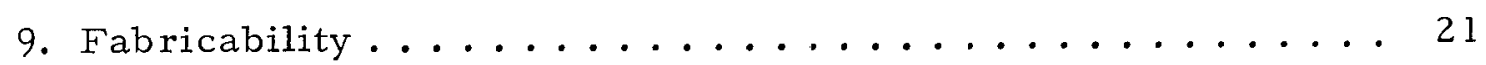

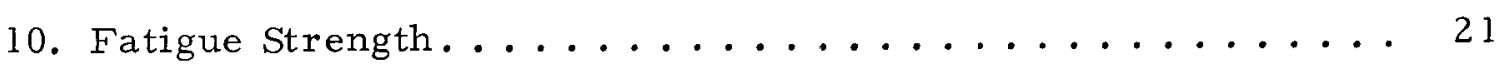

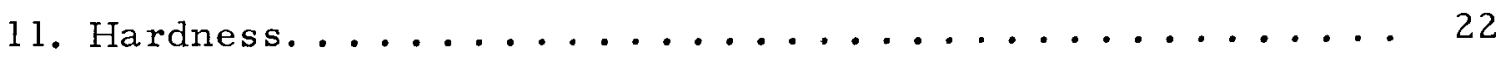

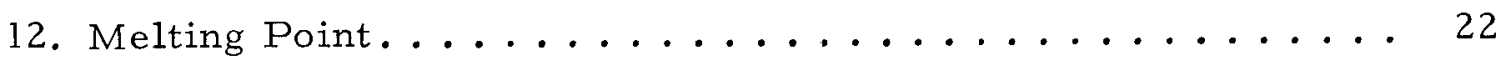

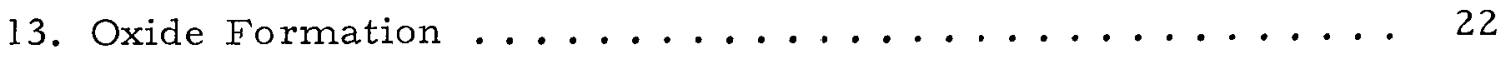

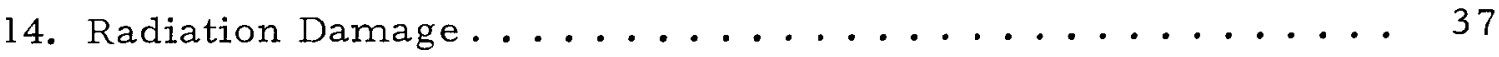

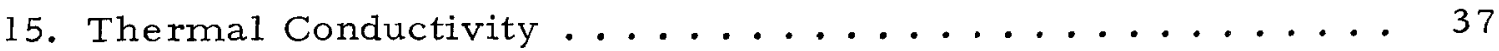

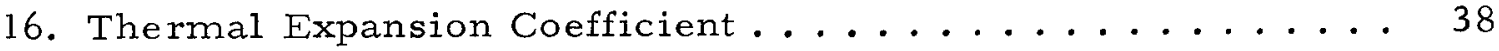

17. Transmutation to a Radioactive Source............ 38

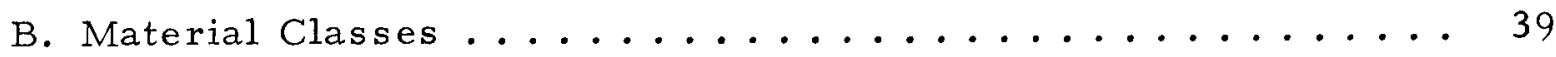

1. Nonrefractory Metals and Alloys............... 39

2. Refractory Metals and Alloys ................... 39

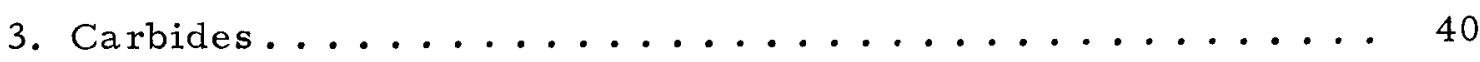

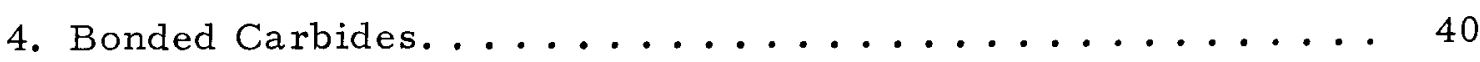

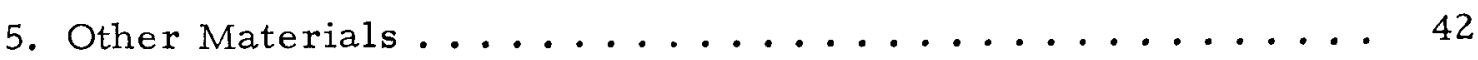




\section{CONTENTS}

II. Mechanical Considerations.................... 45

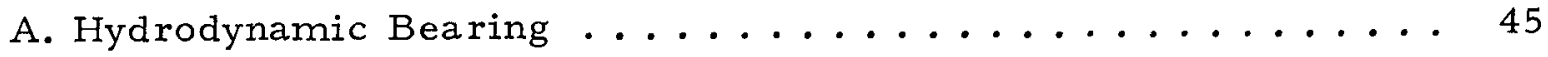

B. Hydrostatic Bearing ..................... 47

C. Rolling-Element Bearings .................. 48

D. Boundary Lubrication of Surfaces .............. 49

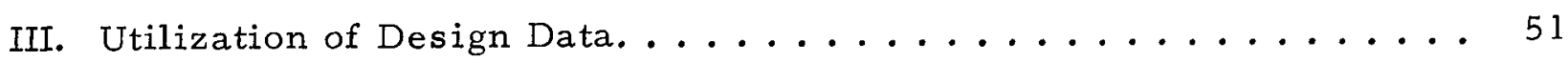

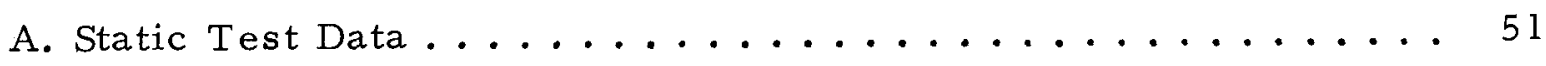

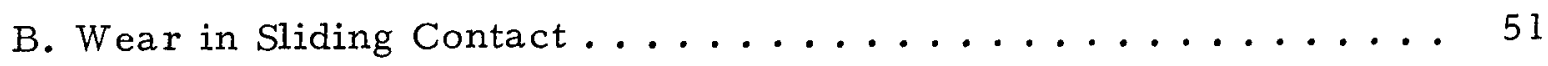

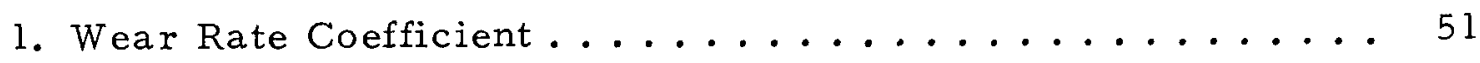

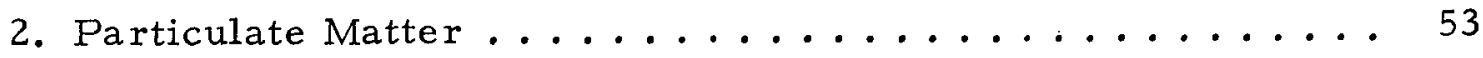

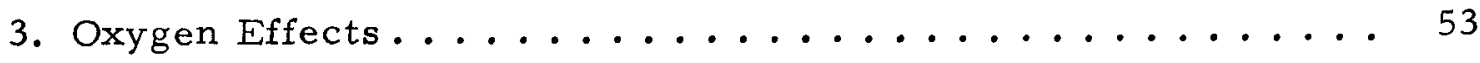

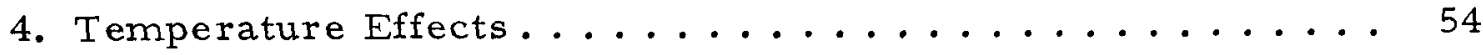

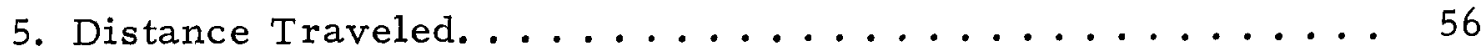

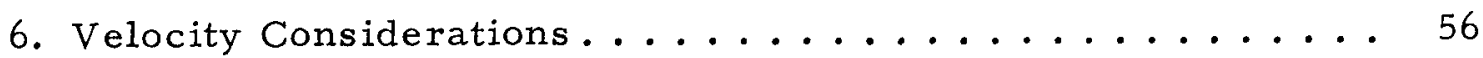

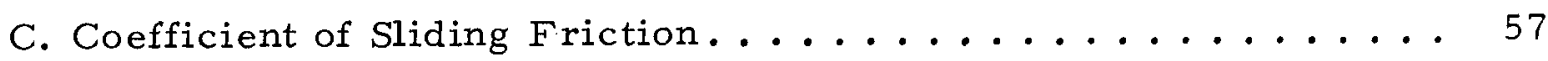

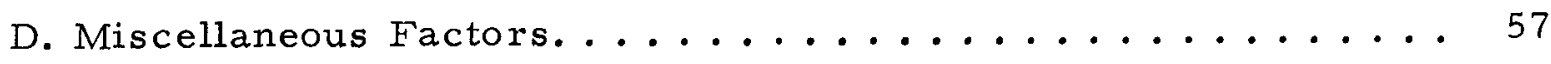

E. Design Values from Screening Test Data............ 57

PART 2. EXPERIMENTAL MATERIAL SCREENING AND ANALYTICAL STUDIES

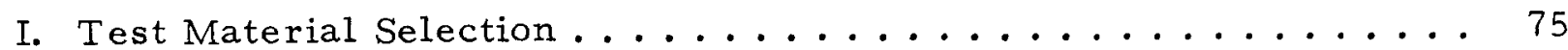

II. Test Equipment Procedures ................... 83

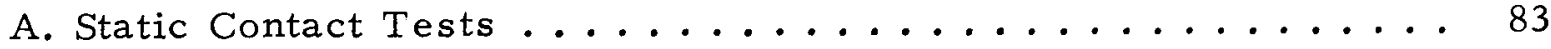

1. Description of Static Contact Test Equipment and

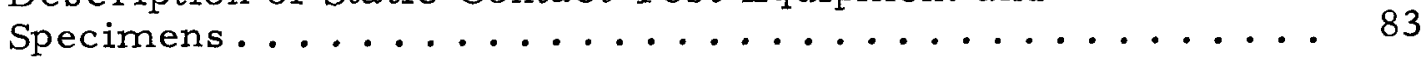

2. Test Procedure for Static Contact Tests............ 92

3. Measurement Techniques for Static Contact Tests ...... 95

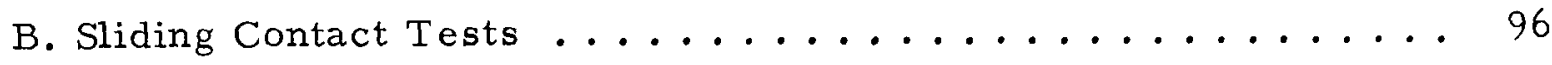

1. Description of Sliding Contact Test Equipment and

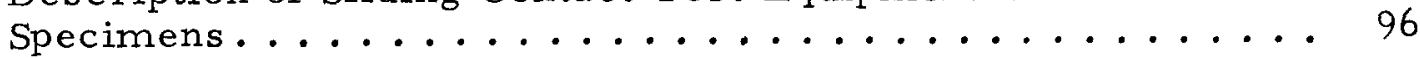

2. Test Procedure for Sliding Contact Tests ........... 104

3. Measurement Techniques for Sliding Contact Tests ...... 105

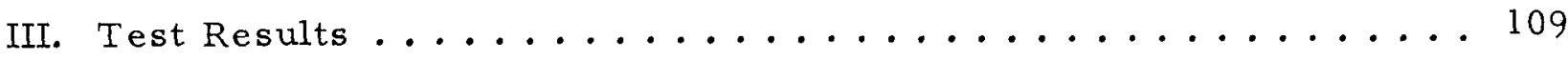




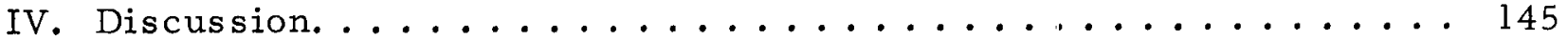

A. Static Contact Test Results. . . . . . . . . . . . 145

B. Sliding Contact Results . . . . . . . . . . . . . 147

1. Correlation with Wear Theory ................. 147

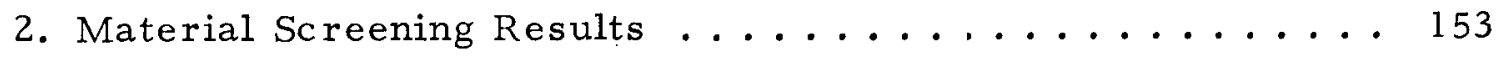

3. Hardness Changes due to Exposures .............. 163

4. Observed Pressure Effects.................. 164

5. Coefficient of Sliding Friction Effects............ 164

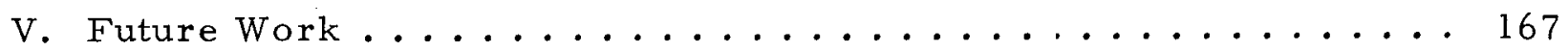

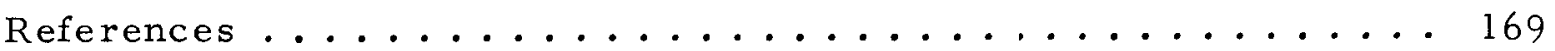

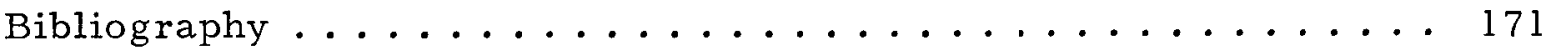

\section{TABLES}

1. Composition, Thermal Expansion, and Hot Hardness of Candidate

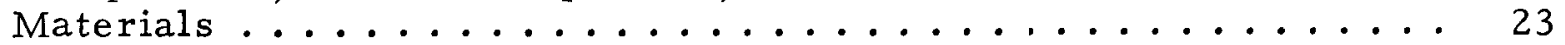

2. Tentative Design Data from Experimental Screening Wear Tests

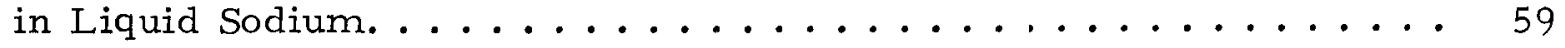

3. Tentative Design Data from Experimental Screening Wear Tests

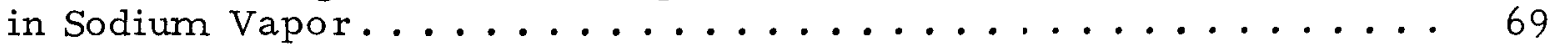

4. Matrix - Sliding Wear in Liquid Sodium at $1200^{\circ} \mathrm{F} \ldots . . . . .73$

5. Matrix - Sliding Wear in Sodium Vapor at $1200^{\circ} \mathrm{F}$. . . . . . 74

6. Chemical Analysis of Test Materials . . . . . . . . . . . . 76

7. Heat Treatments of Test Materials . . . . . . . . . . . 77

8A. Static Contact Results from $1200^{\circ} \mathrm{F}$ Tests - First Material

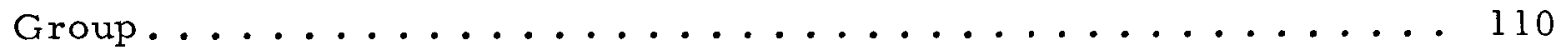

8B. Static Contact Results from $1200^{\circ} \mathrm{F}$ Tests - Second Material

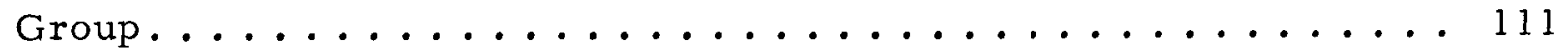

9. Test Data from Sliding Contact Tests in Liquid Sodium . . . . . 112

10. Test Data from Sliding Contact Tests in Sodium Vapor . . . . . . 137

11. Hardness Changes After Exposure to Test Environment ...... 163 


\section{FIGURES}

Page

1. Free Energy as a Function of Temperature............ . 37

2. Curve Showing Typical Relationship Between Wear and Load . . . . 52

3. Approximate Oxygen Saturation Values as a Function of

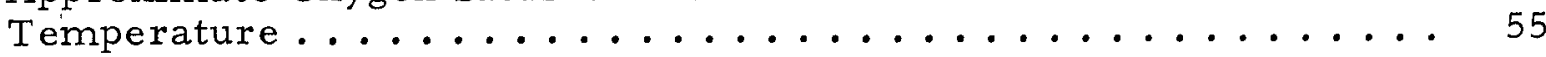

4. Volume Lost per Unit Load as a Function of Distance Traveled . . 56

5. Static Contact and Sliding Contact Apparatus . . . . . . . . . . 84

6. Static Contact Test Process Schematic and Perspective Layout . . 85

7. Static Contact Apparatus ..................... 86

8. Static Contact Apparatus - Typical Pins and Plate Arrange-

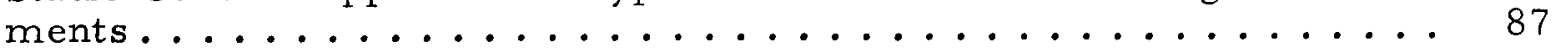

9. Static Contact Apparatus Showing Plates Installed . . . . . . 88

10. Static Contact Apparatus Showing Specimen Pins . . . . . . . 89

11. Static Contact Apparatus Showing Specimen Pins and Plates in

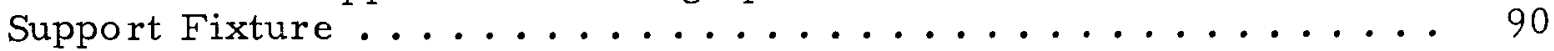

12. Sliding Contact Test Process Schematic and Perspective

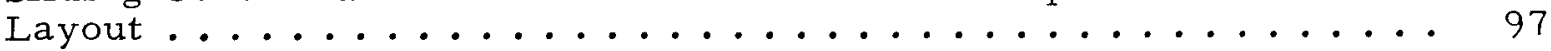

13. Sliding Contact Apparatus. . . . . . . . . . . . . . 98

14. Typical Sliding Contact Wear Plate and Pins . . . . . . . . . 99

15. Sliding Contact Apparatus Components . . . . . . . . . . 100

16. Pin Configuration - Engineering Drawing ............ 101

17. Plate Configuration - Engineering Drawing .......... 102

18. Evidence of Creep Deformation in Static Tests . . . . . . . . 146

19. Distribution of Static Coefficient of Friction in a Sodium

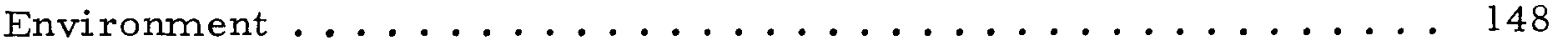

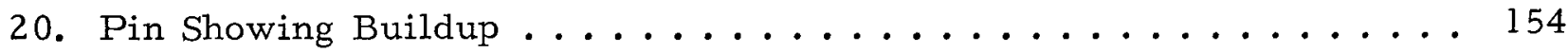

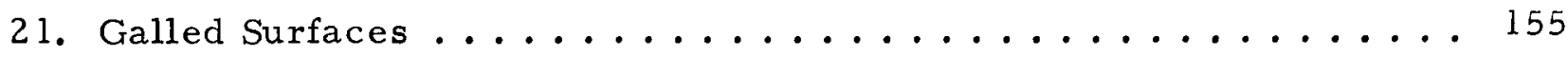

22. Scanning Electron Microscope Photographs - TZM Molybdenum Alloy Pin after Sliding Contact Against Tungsten Plate at $130 \mathrm{psi}$ in $1200^{\circ} \mathrm{F}$ Liquid Sodium (Test 40 ). . . . . . . .

23. Scanning Electron Microscope Photographs - Tungsten Pin after Sliding Contact Against Hastelloy C Plate at 119 psi in $1200^{\circ} \mathrm{F}$ Sodium Vapor (Test 98).

24. Scanning Electron Microscope Photographs - Inconel 718 Pin after Sliding Contact Against Udimet 630 Plate at 83 psi in $1200^{\circ} \mathrm{F}$ Liquid Sodium (Test 368).

LMEC-70-10 


\section{FIGURES}

25. Scanning Electron Microscope Photographs - Hastelloy C Pin after Sliding Contact Against Hastelloy C Plate at 101 psi

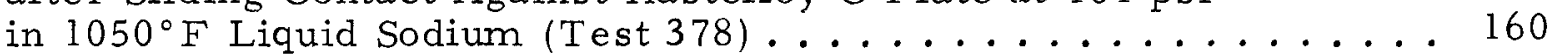

26. Scanning Electron Microscope Photographs - Stellite 1 Pin after Sliding Contact Against Stellite 6B Plate at: 130 psi

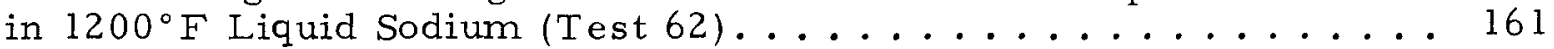

27. Wear Coefficient of Type 304 SS Rubbing on Stellite 1016 as a Function of Temperature..................... . 162

28. Wear Coefficient of Austenitic Stainless Steel Rubbing on Itself in $1200^{\circ} \mathrm{F}$ Sodium as a Function of Contact Pressure. . . . . 164

29. Scanning Electron Microscope Photographs of Type 300 Series Stainless-Steel Pins Showing Results of siliding Contact in $1200^{\circ} \mathrm{F}$ Sodium as a Function of Contact

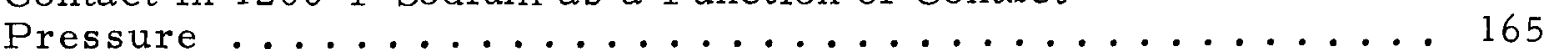

30. General Shape of Coefficient of Sliding Friction Data as a

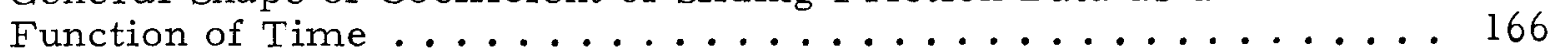




\section{INTRODUCTION}

OBJECTIVE

The objective of this work is twofold: (1) to summarize analytical and experimental screening work performed by the Liquid Metal Engineering Center (LMEC) in evaluating contact surface couples in sodjum vapor and liquid, and (2) insofar as possible, to present this information specifically for the consideration of a designer on the subject of contact surfaces in a sodium environment. The screening work has included obtaining significart data, proposing a model for the wear mechanism involved in these tests based on the data, and establishing standardized units for quantitatively defining wee.r data to the designer.

\section{BACKGROUND}

Coolant sodium in contemplated future nuclear reactors presumably will be used near $650^{\circ} \mathrm{C}\left(1200^{\circ} \mathrm{F}\right)$. Sodium in liquid or vapor form can cause removal of oxide-bearing surface layers which provide corrosion resistance and lubrication (to some degree) in normal oxygen-containing environments. At $650^{\circ} \mathrm{C}$, sodium is not only an apparent solvent for many materials, but a media through which mass transfer can occur to a serious degree. These properties can change substantially the character of numerous alloys and compounds in contact with sodium. High operating temperatures of materials in sodium systems can enhance these severe effects by promoting solid-statediffusion within the materials and surface diffusion at the sodium interface. These changes combine to cause: (1) increases in coefficients of sliding friction, (2) "self"-or diffusion-welding,

(3) degradation of material properties with time, and (4) microstructural failure at surfaces with consequent roughening and acceleration of wear. An additional problem is the deposition of sodium layers or droplets and sodium oxide on mechanisms operating above a liquid sodium surface. On the other hand, complex oxides of sodium and one of the rubbing metals in a sliding couple can act as a lubricant and hence reduce wear. Further, mclten sodium itself can occasionally act as a lubricant.

The intended functions of most devices or mechanisms are performed primarily by means of moving elements such as bearings, gears, guides, etc., where dynamic surfaces are in continuous or intermittent sliding and/or rolling 
contact. When a mechanical element is required to operate in sodium, the described degradation factors peculiar to this environment may greatly reduce mechanical life and reliability.

Resistance to wear and galling are not fixed properties of a material and no arrangement of formulae have been developed to predict these satisfactorily. Wear and galling are surface phenomena consisting of the gradual mechanical deterioration of contacting surfaces, as in the tearing off of particles, plowing of surfaces by these particles, or welding of surface contact areas through friction. They have been described technically as being caused by a complex combination of factors, including molecular adhesion, abrasion, corrosion, and surface fatigue. Wear and galling involving mechanical elements are also influenced by other factors such as types of motions concerned, loads, speeds, distance of travel, dimensional clearances, alignment, design details, and, particularly, temperature of operation. It has always been necessary to depend on tests to determine friction resistance, wear, and galling characteristics of mechanical elements and material combinations. There is no quantitative relationship between friction and wear, so tests for each of these must be performed.

The present work includes and updates information in a document issued by the LMEC in September 1967. This document was NAA-SR-12446, "Static and Sliding Contact Behavior of Materials in Sodium Environments at Elevated Temperature, "by W. J. Freede, L. Newcomb, and R. S. Kennedy. (1)* A searchwas made of literature reporting information published since 1950 on mechanical devices with rubbing surfaces operating in alkali metals. The results of this search were issued in December 1968 in LMEC-68-5, "Mechanical Elements Operating in Sodium and Other Alkali Metals, Volume I, Literature Survey, " by J. K. Balkwill. (2) The Balkwill report also discussed the characteristics of potentially useful materials that are important in liquid metal applications. The present report has utilized pertinent portions of NAA-SR- 12446 and LMEC68-5, particularly in the subsections "Material Considerations" and "Hardware Considerations."

*Superscripts refer to the References listed at the end of this report.

LMEC-70-10 


\section{APPROACH}

The approach used in preparing this report is to present the work in two separate parts: Part 1, "Considerations for the Designer" and Part 2, "Experimental Material Screening and Analytical Studies. "The part for the designer is presented first and should stand alone to obviate the necessity for the designer having to read through a large mass of experimental detail to find the information he needs. Part 2 has been written for those engineers and scientists performing similar wear and friction experiments.

The following approach has been used in selecting units and nomenclature. In Part 1, "Considerations for the Designer, "the data are expressed in the English system for the benefit of the designer. In Part 2, the test results are in metric units, as these units are the ones usually used in studies on wear. The terms, complex oxides and polyoxides, are used interchangebly in this report as names for the sodium metallate or metallite surface layers often formed.

An effort has been made in this report to differentiate between wear and friction effects. In this respect, the term galling presents a particularly difficult problem. Galling is understood by some to mean the wear of a rubbing surface due to intermittent self-welding and consequent tearing away of material fragments. Many engineers, however, use the term galling to mean increases in frictional forces up to and including the point of seizure between sliding parts. Within the text of this report, the terminology, "increase in the coefficient of sliding friction, "is used to describe this latter phenomenon. The term galling is generally avoided in this report except in several tables, where the letter, "G", for galling is used for the sake of brevity to denote very large increases in the frictional forces, increases to the point where material fragments are torn off the surfaces. When used in this sense, the term galling implies both roughened surfaces and very large coefficients of sliding friction. 


\section{SUMMARY AND CONCLUSIONS}

Screening tests have been performed on a large number of materials to determine which material couples will operate adequately in applications involving surface contact within sodium vapor or liquid. Although this work was primarily designed to screen candidate material couples, there has been generated a large amount of quantitative data which may be useful to the designer. The first part of this report contains details for the designer on the limitations and uses of these data. The second part describes the experiments performed in considerable detail. This latter section has been written for those engineers and scientists performing similar wear and friction experiments.

The conclusions for Part 1 are as follows:

1) Experimental wear data are to be used by the designer only if he can design his part to operate under approximately the same conditions (temperature and pressure, in particular) as were present in the experiment.

2) If the actual parameters of temperature, surface pressure, rubbing velocity, oxygen activity, and total distance to travel do not correspond to those of previously run tests, basic wear data should be generated with duplication of the design parameters. In particular, no extrapolation should be done in the direction of lower or extremely higher pressures or higher temperatures.

3) Changes in the sliding coefficient of friction during a run a re often a more serious design consideration than the wear itself. Wear, itself, in sodium is not a particularly extreme problem.

4) The low load range $(0.2<\mathrm{L}<2.0 \mathrm{lb})$, or low pressure range $(10<\mathrm{P}$ $<100$ psi), may cause wear problems not present at slightly lower or slightly higher load or contact pressure values.

5) Surface layers of complex oxides often provide lubrication. These complex oxides may not form after the structural alloy has changed its surface composition because of long exposure to liquid sodium. 
6) At $500^{\circ} \mathrm{F}$, almost every couple worked. At $1200^{\circ} \mathrm{F}$, only the bonded carbides and/or metal-ceramic composites, in terms of an entire material class, showed good possibilities; individual cases of good behavior occurred in other material classes.

7) Tentative design data from experimental screening wear tests in sodium liquid and vapor are summarized in Part 1 of this report (Tables 2 and 3). Matrices giving relative ranking of test material combinations are also presented in Part 1 (Tables 4 and 5).

The conclusions drawn for Part 2 are as follows:

1) Evidence is given that the types of wear are additive. The explanation, then, as to why low coefficients of friction do not indicate low wear is straightforward - one of the other additive terms can become dominant. Any equation written to describe wear must be composed of additive terms. Such terms include work hardening, surface, hardness, debris volume, velocity, coefficient of friction, pressure, and temperature parameters.

2) The scanning electron microscope is one of the most powerful tools for explaining which type of wear mechanism is dominant. Not only does each worn material have its own characteristic appearance in scanning electron microscope photographs, but the relative importance of the additive terms in the wear equation can be estimated.

3) Transition temperatures between regimes of low and high wear rates have to be defined quantitatively by future experimental work.

4) A transition pressure regime, which appears to be between 30 and 100 psi for wear in $1200^{\circ} \mathrm{F}$ sodium, should be carefully investigated. 
PART 1

CONSIDERATIONS FOR THE DESIGNER 


\section{MATERIAL CONSIDERATIONS}

\section{A. REQUIRED MATERIAL CHARACTERISTICS}

The friction and wear behavior of materials sliding on one another depends in a complex way on a number of physical and chemical characteristics of the wearing materials. Additional characteristics important to the final element design, such as cost and fabricability, must be considered in selecting the material. The requirement of operation with a high-temperature alkali metal environment as the lubricant changes significantly the relative importance of the various material characteristics as compared to operation with conventionally lubricated elements.

The many characteristics commonly considered in selection of bearing materials in addition to wear and coefficient of friction are discussed in this section under specific headings, with special emphasis on the effect of the alkali metal environment on the importance of each characteristic. The listing is alphabetical; no attempt is made to determine the order of importance to the final element design, since this order may vary with each application. The characteristics are:

1) Alloying tendency of couples.

10) Fatigue strength.

2) Compressive strength.

11) Harciness.

3) Conformability.

12) Melting point.

4) Corrosion resistance.

13) Oxide formation.

5) Cost.

14) Radiation damage.

6) Dimensional stability.

15) Thermal conductivity.

7) Ductility and impact strength.

16) Thermal expansion coefficient.

8) Elastic modulus.

17) Trarsmutation to a radioactive

9) Fabricability. source. 


\section{Alloying Tendency of Couples}

Much of the early work on wear emphasized the alloying tendency of the material of a rubbing surface with the material of the other surface. In fact, the nonabrasive mode of wear was thought to be describable in terms of such tendencies. If material $\mathrm{A}$ formed a solid solution in material $\mathrm{B}$, much wear took place. If a brittle intermetallic compound was formed, the welded joint formed would be easily broken and very little wear would occur. This simple picture had to be modified to include the roles of oxide effects and substrate ductility on adhesive wear. The relative hardness of a rubbing surface with respect to particulate debris has long been known to affect abrasive wear, but it took the advent of electron microscope replication techniques to show that adhesion was often cause by foreign particles sticking into both rubbing surfaces and being sheared. Other parameters also influence adhesive wear such as the work hardening exponent and the transfer back and forth of adhesive wear debris. All these other parameters taken together overwhelm the original hypothesis that the alloying tendencies determined adhesive wear behavior. However, this factor should probably still be taken into account when choosing a material couple for surface contact applications.

\section{Compressive Strength}

When a steadily applied load is considered, the load-carrying capacity of a bearing is often directly related to its compressive strength and to the viscosity of the lubricant that determines the film-bearing capacity. The low viscosity of liquid metals results in a low film-bearing capacity relative to conventional lubricants, so that an increase in bearing area or a reduction in bearing clearance, or both, is required over that of a conventionally lubricated design to maintain the same bearing load-carrying capacity. Where the film-bearing capacity is not controlling, the liquid-metal-lubricated bearing tends to become very large, and it is important to have a material with as high a compressive strength as possible to keep the size reasonable.

\section{Conformability}

Conformability, the ability of a bearing couple to change configuration to compensate for misalignment and geometric inaccuracies (wearing-in), is an important property of bearing materials in conventionally lubricated systems. 
Good conformability generally results from low hardness and low modulus of elasticity, but the classes of materials that have good corrosion resistance in liquid metals generally have high hardness and high modulus of elasticity. Other considerations may also dictate a high hardness and high elastic modulus requirement in a liquid metal bearing, so that conformability is usually not possible.

The high temperatures associated with liquid metal systems make the alignment problem particularly severe. It follows that extreme precision in design, fabrication, and installation of rubbing surfaces in liquid metals is required to compensate for the lack of conformability. The lubricating fluid must then be kept exceptionally clean, because the danger of damage from a particle passing through such a nonconforming bearing is much greater.

\section{Corrosion Resistance}

Where corrosion resistance seldom influences material selection in conventionally lubricated systems, it is the first characteristic considered in liquid metal systems and one of the most important. The bearing material must be completely compatible with the liquid metal environment at the operating temperature over the life of the bearing. Intergranular corrosion or selective attack along certain crystallographic planes can roughen the surface finish enough to cause failure. The strength or hardness of the material surface can be affected detrimentally by selective leaching of alloying elements, leading to early fatigue failure of the surface and then the element. Finally, material compatibility with the liquid metal system as a whole must be established; where a bearing material may have excellent corrosion resistance in a static liquid metal test, it may show mass transfer behavior in a dynamic system when the liquid metal contacts another (construction) material. This could result in rapid loss of an alloying element from the bearing material by selective leaching and failure of the element. The actual amount of material leached from a bearing will be small, but it may still present a problem if it is highly radioactive; this factor should be considered in evaluating the corrosion rate of a bearing material.

\section{5. $\underline{\text { Cost }}$}

Unlike conventionally lubricated mechanical devices, cost does not play an important part in the selection of materials for liquid-metal-lubricated devices. 
Difficulty of access to the bearing in a nuclear system may prevent scheduled frequent replacement, and the resulting long lifetime and high reliability requirements demand the use of the best design and materials available. The original installed cost of a liquid metal bearing loses significance when compared with the cost of repairing a failed unit.

6. Dimensional Stability

Because the load-carrying capacity of a bearing is proportional to the viscosity of the lubricant, bearings lubricated with liquid metals must be designed with increased bearing area or reduced film thickness, or both, compared with conventionally lubricated bearings. The film thickness is generally reduced as far as manufacturing capabilities permit; and it is essential, therefore, that dimensional changes caused by metallurgical instability be negligible to maintain the proper design clearances during the life of the bearing.

\section{Ductility and Impact Strength}

Some degree of ductility and impact strength is desirable in all bearing material applications to prevent damage or failure from shock loading and to provide good "embedability," the ability to absorb foreign particles coming through the bearing without suffering scoring or wear. However, hard materials, such as bonded carbides that have performed well in liquid metals, have very poor embedability. When these materials are used in applications with close clearances, the system should also be designed for extremely good wear resistance to prevent wear debris from damaging the surfaces. The entire liquid metal inventory must also be kept clean and free from debris, such as insoluble corrosion products from structural materials, that could damage the bearing while passing through it.

\section{Elastic Modulus}

A high elastic modulus at the operating temperature will permit high loading without plastic deformation and with minimum elastic deformation. This is necessary to maintain the dimensional stability of the small clearance design required in liquid metal bearings. The high elastic modulus is not desirable in that it means the material will have poor embedability. When grit passes through conventional bearings, with their much greater clearances, a low elastic 
modulus permits passage with minimum scoring; arld, if the proportional limit has not been exceeded, the bearing will return to itis original shape after the particle has passed through it. Such operation is not possible when a highmodulus material is used with the small clearance design of liquid metal bearings, and bearing surface damage may be expected when grit is present in the lubricant of such bearings.

\section{Fabricability}

Fabricability has not been a problem with the comparatively small sizes of liquid metal bearings produced to date. Alloys and carbides have been supplied as solid pieces, cast, wrought, or sintered; but solid construction is not practical for a 20-in.-diameter bearing, for example. Hard-facing, flame-spraying, plasma-spraying, and surface-alloying bearing materials on structural base metals are all possible techniques for producing the large units that will be required for an application such as a 30,000-gpm sodium pump. Bearing materials being considered for use in such large units must therefore be amenable to satisfactory application and finishing techniques. Extensive development work would seem to be indicated to determine the best base metal, application technique, and final finishing operations for these large units, and to demonstrate the long-time integrity of the bond between bearing material and base metal.

An important requirement of any fabrication process is that uniformity of product properties, both physical and chemical, from one unit to the next is absolutely essential if the high reliability required of liquid metal bearings is to be achieved. Changes in material chemistry or processing procedures that affect the dimensional stability, strength, hardness, or surface properties could have a serious effect on the performance of the final element. The bearing material must, therefore, be amenable to suitable quality control procedures.

10. Fatigue Strength

A high fatigue strength is essential in any bearing material to prevent fatigue cracking of the surface, spalling, and eventual failure. Fatigue failures in bearings are common where cyclic conditions of load and temperature are encountered. The liquid metal environment may prove beneficial in fatigue- 
inducing situations when its excellent thermal conductivity and heat capacity will act to prevent large temperature differences from developing from point to point in the bearing surface.

\section{Hardness}

Generally, a material with a high room-temperature hardness can be given a higher surface finish that results in a more uniform contact area, less tendency to have asperous welding, and, therefore, less wear. The hot hardness of a material at its service temperature, however, is a more important measure of its serviceability than is the room-temperature hardness; a high hot hardness will tend to keep load-carrying capacity from decreasing, and wear rates from increasing, at service temperatures. Since hot hardness values at $1200^{\circ} \mathrm{F}$ are difficult to find in the literature, Table 1 has been included here for the designer.

\section{Melting Point}

The mechanical properties of metallic materials deteriorate, in general, as the melting point is approached, so that the high melting point is desirable in high-temperature applications simply to maintain the mechanical properties of the material that influences the load-carrying capacity of the bearing. The melting point should be high to prevent incipient fusion from frictional heating at the highly stressed points of contact. A high melting point also means lower atomic mobility at the service temperature and, therefore, lower diffusion rates and less tendency to bond at the contact points. The higher melting point thus reduces the alloying tendency of the bearing couple, a very desirable feature in liquid metal applications.

\section{Oxide Formation}

The most critical material characteristics are the solubility, stability, and nature of the surface oxide formed in molten sodium. Many sodium structural metal polyoxides can serve as lubricants in the temperature range where they are stable. Comparisons of free energy as a function of temperature plots for sodium with dissolved oxygen and for the appropriate polyoxide would give the temperature range for low wear. A typical graph is shown in Figure 1, where $M$ represents a metal and $x, y$, and $z$ show the stoichiometry of the oxides involved and may be either integers or fractions. 
TABLE 1

COMPOSITION, THERMAL EXPANSION, AND HOT HARDNESS OF CANDIDATE MATERIALS

(Sheet 1 of 14)

\begin{tabular}{|c|c|c|c|}
\hline Material & $\begin{array}{c}\text { Composition } \\
(\%)\end{array}$ & $\begin{array}{c}\text { Mean } \\
\text { Coefficient of } \\
\text { Thermal } \\
\text { Expansion } \\
(\text { from } 70- \\
\left.1200^{\circ} \mathrm{F}\right) \\
\left(\mu \text { in. } / \text { in. } /{ }^{\circ} \mathrm{F}\right)\end{array}$ & $\begin{array}{l}\text { Hardness } \\
\left(\text { at } 1200^{\circ} \mathrm{F}\right)\end{array}$ \\
\hline \multicolumn{4}{|l|}{ Nickel-Base Alloys: } \\
\hline $\begin{array}{l}\text { Inconel X-750 } \\
\text { (wrought) }\end{array}$ & $\begin{array}{ll}\text { Nickel* } & 70.0 \mathrm{~min} \\
\text { *Always contains small } \\
\text { amount colbalt } \\
\text { Chromium } & 14.0-17.0 \\
\text { Iron } & 5.0-9.0 \\
\text { Titanium } & 2.25-2.75 \\
\text { Aluminum } & 0.40-1.00 \\
\text { Niobium* } & 0.70-1.20 \\
\text { *Contains small } \\
\text { amount tantalum } \\
\text { Manganese } & 1.0 \mathrm{max} \\
\text { Silicon } & 0.5 \mathrm{max} \\
\text { Sulfur } & 0.01 \mathrm{max} \\
\text { Copper } & 0.5 \mathrm{max} \\
\text { Carbon } & 0.08 \mathrm{max}\end{array}$ & 8.4 & $R_{C} 28-30$ \\
\hline $\begin{array}{l}\text { Inconel } 718 \\
\text { (wrought) }\end{array}$ & $\begin{array}{ll}\text { Nickel } & 53.0 \\
\text { Chromium } & 18.5 \\
\text { Iron } & 18.0 \\
\text { Niobium* } & 5.1 \\
\text { *Contains small } \\
\text { amount tantalum } \\
\text { Molybdenum } & 3.0 \\
\text { Titanium } & 1.0 \\
\text { Aluminum } & 0.5 \\
\text { Silicon } & 0.25 \\
\text { Manganese } & 0.2\end{array}$ & 8.6 & $R_{C} 37-40$ \\
\hline
\end{tabular}

LMEC-70- 10 
TABLE 1

COMPOSITION, THERMAL EXPANSION, AND HOT HARDNESS OF

CANDIDATE MATERIALS

(Sheet 2 of 14)

\begin{tabular}{|c|c|c|c|}
\hline Material & $\begin{array}{c}\text { Composition } \\
(\%)\end{array}$ & $\begin{array}{c}\text { Mean } \\
\text { Coefficient of } \\
\text { Thermal } \\
\text { Expansion } \\
\text { (from } 70- \\
\left.1200^{\circ} \mathrm{F}\right) \\
\left(\mu \text { in. } / \text { in. } /{ }^{\circ} \mathrm{F}\right)\end{array}$ & $\begin{array}{l}\text { Hardness } \\
\left(\text { at } 1200^{\circ} \mathrm{F}\right)\end{array}$ \\
\hline Inconel 718 (cont) & $\begin{array}{ll}\text { Copper } & 0.1 \\
\text { Cobalt } & 0.1 \\
\text { Carbon } & 0.05 \\
\text { Sulfur } & 0.007\end{array}$ & & \\
\hline $\begin{array}{l}\text { Udimet } 718 \\
\text { (wrought) } \\
\text { (Equivalent } \\
\text { to Inconel } 718 \\
\text { but from } \\
\text { different } \\
\text { supplier) }\end{array}$ & $\begin{array}{ll}\text { Nickel } & 54.2 \\
\text { Chromium } & 18.0 \\
\text { Iron } & 18.0 \\
\text { Niobium* } & 5.2 \\
\text { *Contains small } \\
\text { amount tantalum } \\
\text { Molybdenum } & 3.0 \\
\text { Titanium } & 1.0 \\
\text { Aluminum } & 0.5 \\
\text { Carbon } & 0.04-0.06 \\
\text { Boron } & 0.004\end{array}$ & 8.6 & $R_{C} 37-40$ \\
\hline $\begin{array}{l}\text { Udimet } 630 \\
\text { (wrought) }\end{array}$ & $\begin{array}{ll}\text { Nickel } & 48.3-58.6 \\
\text { Chronium } & 15-19 \\
\text { Iron } & 16-19 \\
\text { Molybdenum } & 2.7-3.4 \\
\text { Niobium* } & 5.8-6.8 \\
\text { *Contains small } \\
\text { amount tantalum } \\
\text { Aluminum } & 0.20-1.00 \\
\text { Carbon } & 0.04 \\
\text { Titanium } & 0.7-1.5\end{array}$ & 8.6 & $R_{C} 41-43$ \\
\hline
\end{tabular}


TABLE 1

COMPOSITION, THERMAL EXPANSION, AND HOT HARDNESS OF CANDIDATE MATERIALS

(Sheet 3 of 14)

\begin{tabular}{|c|c|c|c|c|}
\hline Material & \multicolumn{2}{|c|}{$\begin{array}{c}\text { Composition } \\
(\%)\end{array}$} & $\begin{array}{c}\text { Mean } \\
\text { Coefficient of } \\
\text { Thermal } \\
\text { Expansion } \\
\text { (from } 70- \\
\left.1200^{\circ} \mathrm{F}\right) \\
\left(\mu \text { in. } / \text { in. } /{ }^{\circ} \mathrm{F}\right)\end{array}$ & $\begin{array}{l}\text { Hardness } \\
\left(\text { at } 1200^{\circ} \mathrm{F}\right)\end{array}$ \\
\hline Udimet 630 (cont) & $\begin{array}{l}\text { Cobalt } \\
\text { Boron }\end{array}$ & $\begin{array}{l}1.0 \max \\
0.001-0.007\end{array}$ & & \\
\hline $\begin{array}{l}\text { Hastelloy C } \\
\text { (wrought) }\end{array}$ & $\begin{array}{l}\text { Nickel } \\
\text { Cobalt } \\
\text { Chromium } \\
\text { Molybdenum } \\
\text { Tungsten } \\
\text { Iron } \\
\text { Silicon } \\
\text { Manganese } \\
\text { Carbon } \\
\text { Vanadium } \\
\text { Phosphorus } \\
\text { Silicon }\end{array}$ & $\begin{array}{l}54.0 \\
2.5 \max \\
14.5-16.5 \\
15.0-17.0 \\
3.0-4.5 \\
4.0-7.0 \\
1.0 \max \\
1.0 \max \\
0.08 \max \\
0.35 \max \\
0.04 \max \\
0.03 \max \end{array}$ & 7.3 & $\mathrm{R}_{\mathrm{B}} 87-90$ \\
\hline $\begin{array}{l}\text { Molybdenum-Base } \\
\text { Alloys: }\end{array}$ & & & & \\
\hline $\begin{array}{l}\text { TZM } \\
\text { (pressed and } \\
\text { sintered) }\end{array}$ & $\begin{array}{l}\text { Molybdenum } \\
\text { Titanium } \\
\text { Zirconium } \\
\text { Carbon } \\
\text { Iron } \\
\text { Silicon } \\
\text { Nickel } \\
\text { Oxygen }\end{array}$ & $\begin{array}{l}99.40 \\
0.50 \\
0.08 \\
0.025 \\
0.010 \mathrm{max} \\
0.008 \max \\
0.002 \max \\
0.0025 \max \end{array}$ & 3.1 & $R_{B} 95-97$ \\
\hline
\end{tabular}


TABLE 1

COMPOSITION, THERMAL EXPANSION, AND HOT HARDNESS OF CANDIDATE MATERIALS

(Sheet 4 of 14)

\begin{tabular}{|c|c|c|c|}
\hline Material & Composition & $\begin{array}{c}\text { Mean } \\
\text { Coefficient of } \\
\text { Thermal } \\
\text { Expansion } \\
\text { (from } 70- \\
1200^{\circ} \mathrm{F} \text { ) } \\
\left.\text { ( } \mu \text { in. } / \text { in. } /{ }^{\circ} \mathrm{F}\right)\end{array}$ & $\begin{array}{l}\text { Hardness } \\
\left(\text { at } 1200^{\circ} \mathrm{F}\right)\end{array}$ \\
\hline $\mathrm{TZM}$ (cont) & $\begin{array}{ll}\text { Hydrogen } & 0.0005 \max \\
\text { Nitrogen } & 0.002 \max \end{array}$ & & \\
\hline $\begin{array}{l}\text { Molybdenum } \\
\text { (pressed and } \\
\text { sintered) }\end{array}$ & Molybdenum 99.95 & 3.1 & $R_{B} 71-73$ \\
\hline \multicolumn{4}{|l|}{ Tungsten: } \\
\hline $\begin{array}{l}\text { Tungsten } \\
\text { (pressed and } \\
\text { sintered) }\end{array}$ & Tungsten & 2.4 & $R_{C} 43-45$ \\
\hline \multicolumn{4}{|l|}{ Sintered Carbides: } \\
\hline $\begin{array}{l}\mathrm{K}-95 \\
\text { (pressed and } \\
\text { sintered) }\end{array}$ & $\begin{array}{ll}\text { Tungsten } & 91.0 \\
\text { Cobalt } & 9.0\end{array}$ & 3.4 & ${ }^{R} C^{56-58}$ \\
\hline $\begin{array}{l}K-801 \\
\text { (pressed and } \\
\text { sintered) }\end{array}$ & $\begin{array}{l}\text { Tungsten } \\
\text { carbide } \\
\text { Nickel binder } 6.0\end{array}$ & 3.1 & $\mathrm{R}_{A} 87-89$ \\
\hline $\begin{array}{l}\mathrm{K}-162 \mathrm{~B} \\
\text { (pressed and } \\
\text { sintered) }\end{array}$ & $\begin{array}{ll}\text { Titanium } & \\
\text { carbide } & 63.0 \\
\text { Nickel } & 25.0 \\
\text { Molybdenum } & 5.0 \\
\text { Niobium* } & 5.3 \\
\text { *Contains small } \\
\text { amount tantalum }\end{array}$ & 4.6 & ${ }^{R_{C}} 50-53$ \\
\hline \multicolumn{4}{|l|}{ Tool Steels: } \\
\hline $\begin{array}{l}\text { AISI Ml } \\
\text { (wrought) }\end{array}$ & $\begin{array}{ll}\text { Iron } & 83.5 \\
\text { Molybdenum } & 8.5\end{array}$ & $\begin{array}{c}6.9 \\
(\text { from } 75- \\
\left.900^{\circ} \mathrm{F}\right)\end{array}$ & $R_{C} 43-45$ \\
\hline
\end{tabular}


TABLE 1

COMPOSITION, THERMAL EXPANSION, ANI) HOT HARDNESS OF CANDIDATE MATERIALS

(Sheet 5 of 14)

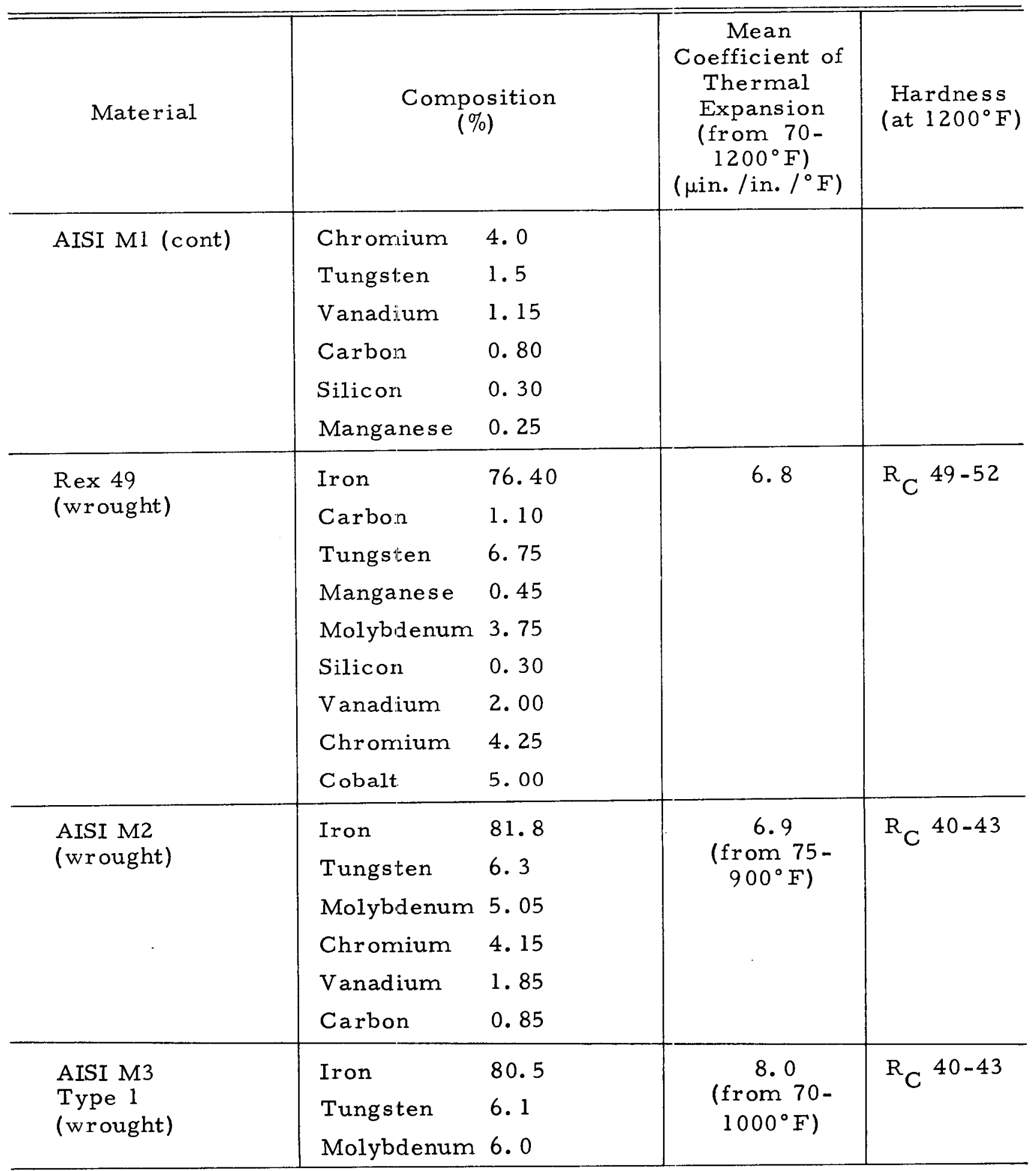


TABLE 1

COMPOSITION, THERMAL EXPANSION, AND HOT HARDNESS OF CANDIDATE MATERIALS

(Sheet 6 of 14)

\begin{tabular}{|c|c|c|c|c|}
\hline Material & Compc & $\begin{array}{l}\text { osition } \\
\text { o) }\end{array}$ & 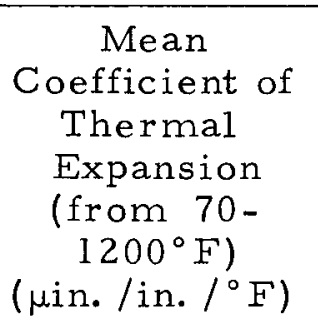 & $\begin{array}{l}\text { Hardness } \\
\left(\text { at } 1200^{\circ} \mathrm{F}\right)\end{array}$ \\
\hline AISI M3 (cont) & $\begin{array}{l}\text { Chromium } \\
\text { Vanadium } \\
\text { Carbon }\end{array}$ & $\begin{array}{l}4.0 \\
2.4 \\
1.02\end{array}$ & & \\
\hline $\begin{array}{l}\text { AISI M3 } \\
\text { Type } 2 \\
\text { (wrought) }\end{array}$ & $\begin{array}{l}\text { Iron } \\
\text { Tungsten } \\
\text { Molybdenum } \\
\text { Chromium } \\
\text { Vanadium } \\
\text { Carbon }\end{array}$ & $\begin{array}{l}79.5 \\
6.0 \\
6.0 \\
4.1 \\
3.2 \\
1.2\end{array}$ & $\begin{array}{c}8.0 \\
(\text { from } 70- \\
\left.1000^{\circ} \mathrm{F}\right)\end{array}$ & $R_{C} 42-44$ \\
\hline $\begin{array}{l}\text { AISI M4 } \\
\text { (wrought) }\end{array}$ & $\begin{array}{l}\text { Iron } \\
\text { Tungsten } \\
\text { Molybdenum } \\
\text { Chromium } \\
\text { Vanadium } \\
\text { Carbon } \\
\text { Manganese } \\
\text { Silicon }\end{array}$ & $\begin{array}{l}79.7 \\
5.5 \\
4.5 \\
4.5 \\
4.0 \\
1.28 \\
0.25 \\
0.25\end{array}$ & $\begin{array}{c}8.0 \\
(\text { from } 70- \\
\left.1000^{\circ} \mathrm{F}\right)\end{array}$ & $R_{C} 44-46$ \\
\hline $\begin{array}{l}\text { AISI M43 } \\
\text { (wrought) }\end{array}$ & $\begin{array}{l}\text { Iron } \\
\text { Cobalt } \\
\text { Molybdenum } \\
\text { Chromium } \\
\text { Tungsten } \\
\text { Vanadium } \\
\text { Carbon }\end{array}$ & $\begin{array}{l}74.6 \\
8.2 \\
8.0 \\
3.75 \\
2.70 \\
1.60 \\
1.20 \\
\end{array}$ & $\begin{array}{c}8.0 \\
(\text { from } 70- \\
\left.1000^{\circ} \mathrm{F}\right)\end{array}$ & $R_{C} 46-48$ \\
\hline
\end{tabular}


TABLE 1

COMPOSITION, THERMAL EXPANSION, AND HOT HARDNESS OF CANDIDATE MATERIALS

(Sheet 7 of 14)

\begin{tabular}{|c|c|c|c|c|}
\hline Material & \multicolumn{2}{|c|}{$\begin{array}{c}\text { Composition } \\
(\%)\end{array}$} & $\begin{array}{c}\text { Mean } \\
\text { Coefficient of } \\
\text { Thermal } \\
\text { Expansion } \\
(\text { from } 70- \\
\left.1200^{\circ} \mathrm{F}\right) \\
\left(\mu \text { in. } / \text { in. } /^{\circ} \mathrm{F}\right)\end{array}$ & $\begin{array}{l}\text { Hardness } \\
\left(\text { at } 1200^{\circ} \mathrm{F}\right)\end{array}$ \\
\hline $\begin{array}{l}\text { AISI T I } \\
\text { (wrought) }\end{array}$ & $\begin{array}{l}\text { Iron } \\
\text { Tungsten } \\
\text { Chromium } \\
\text { Vanadium } \\
\text { Carbon } \\
\text { Molybdenum } \\
\text { Silicon } \\
\text { Manganese }\end{array}$ & $\begin{array}{l}74.8 \\
18.0 \\
4.1 \\
1.1 \\
0.75 \\
0.70 \\
0.25 \\
0.25 \\
\end{array}$ & $\begin{array}{c}8.0 \\
(\text { from } 70- \\
\left.1000^{\circ} \mathrm{F}\right)\end{array}$ & $R_{C} 39-41$ \\
\hline $\begin{array}{l}\text { AISI T } 15 \\
\text { (wrought) }\end{array}$ & $\begin{array}{l}\text { Iron } \\
\text { Tungsten } \\
\text { Cobalt } \\
\text { Vanadium } \\
\text { Chromium } \\
\text { Carbon } \\
\text { Molybdenum }\end{array}$ & $\begin{array}{l}70.7 \\
12.5 \\
5.0 \\
5.0 \\
4.75 \\
1.57 \\
0.50\end{array}$ & $\begin{array}{c}8.0 \\
(\text { from } 70- \\
\left.1000^{\circ} \mathrm{F}\right)\end{array}$ & $R_{C} 40-42$ \\
\hline AISI $M-15$ & $\begin{array}{l}\text { Iron } \\
\text { Chromium } \\
\text { Cobalt } \\
\text { Molybdenum } \\
\text { Vanadium } \\
\text { Carbon } \\
\text { Tungsten }\end{array}$ & $\begin{array}{l}74.5 \\
4.0 \\
5.0 \\
3.5 \\
5.0 \\
1.5 \\
6.5\end{array}$ & & \\
\hline
\end{tabular}


TABLE 1

COMPOSITION, THERMAL EXPANSION, AND HOT HARDNESS OF CANDIDATE MATERIALS

(Sheet 8 of 14)

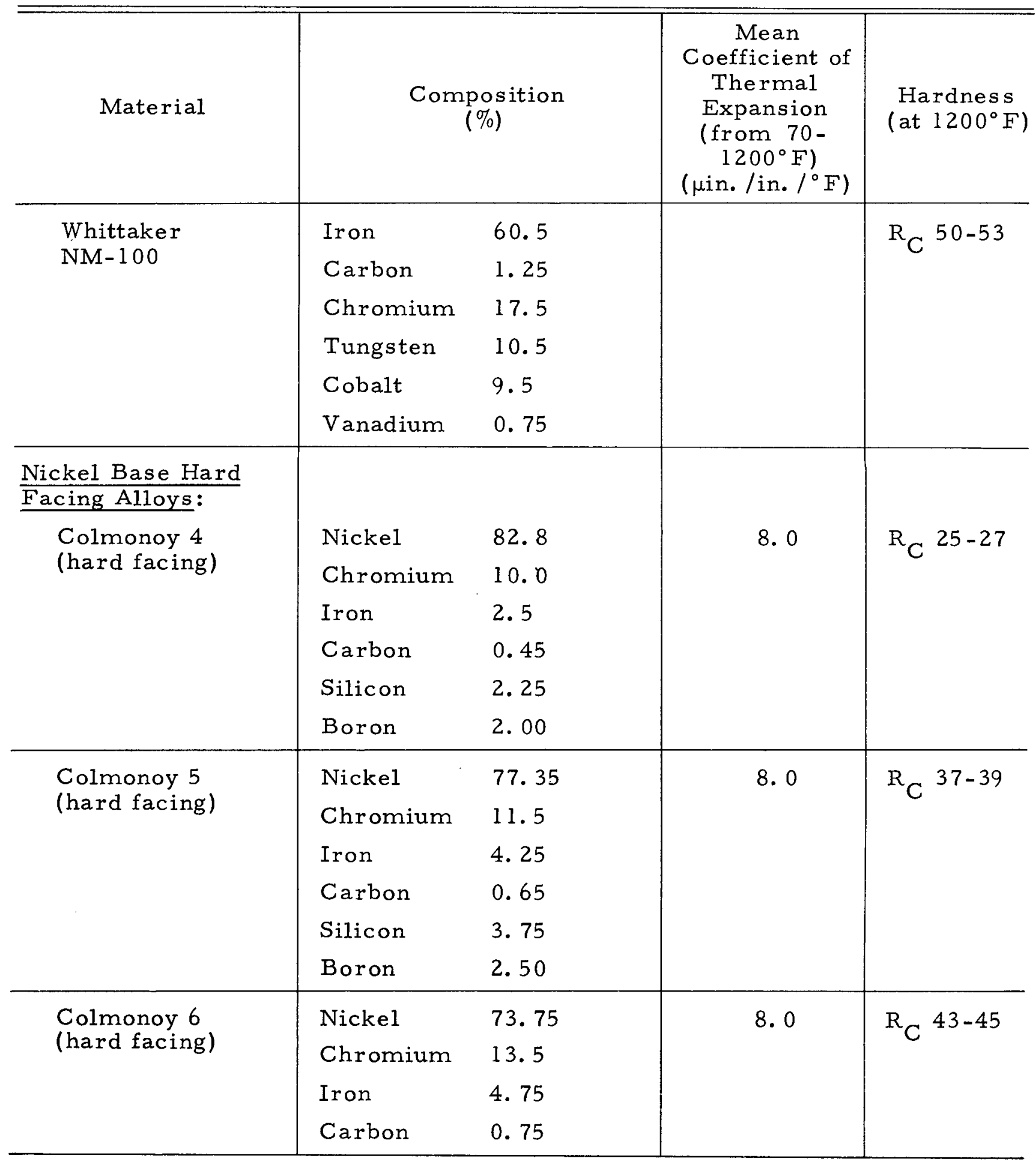


TABLE 1

COMPOSITION, THERMAL EXPANSION, AND HOT HARDNESS OF CANDIDATE MATERIALS

(Sheet 9 of 14)

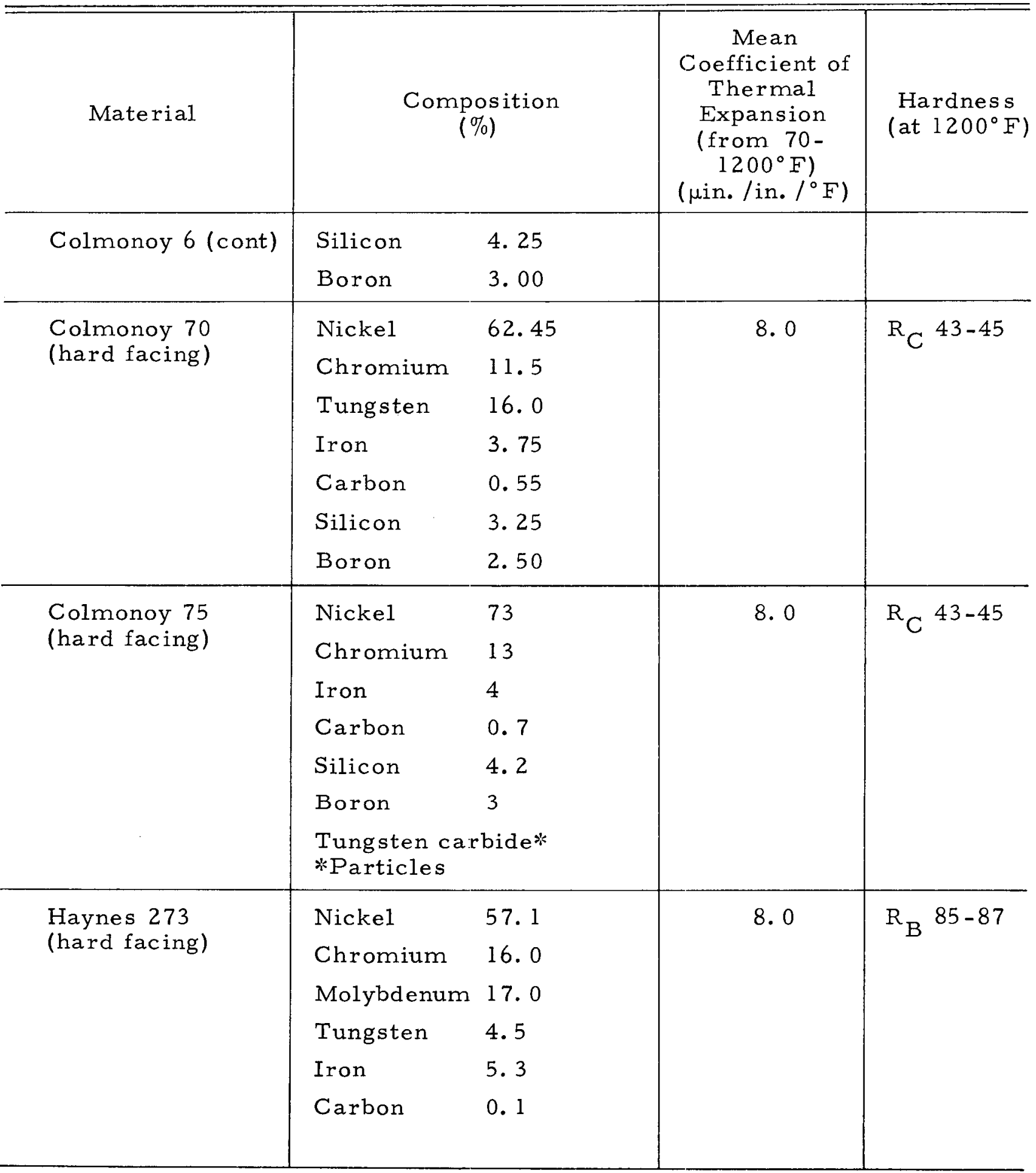


TABLE 1

COMPOSITION, THERMAL EXPANSION, AND HOT HARDNESS OF CANDIDATE MATERIALS

(Sheet 10 of 14)

\begin{tabular}{|c|c|c|c|c|}
\hline Material & $\begin{array}{r}\text { Compo } \\
(\%\end{array}$ & o) & 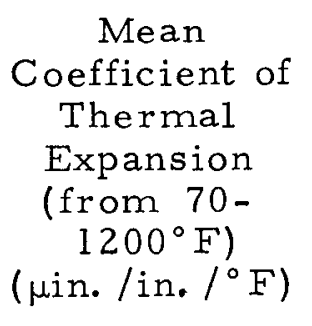 & $\begin{array}{l}\text { Hardness } \\
\left(\text { at } 1200^{\circ} \mathrm{F}\right)\end{array}$ \\
\hline 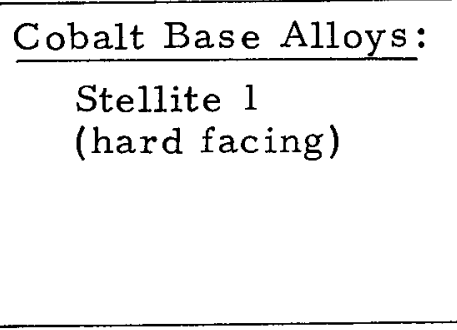 & $\begin{array}{l}\text { Cobalt } \\
\text { Chromium } \\
\text { Tungsten } \\
\text { Carbon }\end{array}$ & $\begin{array}{l}55.5 \\
30.0 \\
12.0 \\
2.5\end{array}$ & 7.3 & $R_{C} 40-42$ \\
\hline $\begin{array}{l}\text { Stellite } 3 \\
\text { (cast) }\end{array}$ & $\begin{array}{l}\text { Cobalt } \\
\text { Chromium } \\
\text { Tungsten } \\
\text { Nickel } \\
\text { Iron } \\
\text { Carbon } \\
\text { Silicon }\end{array}$ & $\begin{array}{l}47.6 \\
30.5 \\
12.5 \\
3.0 \\
3.0 \\
2.45 \\
1.0\end{array}$ & 7.3 & $R_{C} 35-37$ \\
\hline $\begin{array}{l}\text { Stellite 6B } \\
\text { (wrought) }\end{array}$ & $\begin{array}{l}\text { Cobalt } \\
\text { Chromium } \\
\text { Tungsten } \\
\text { Nickel } \\
\text { Iron } \\
\text { Silicon } \\
\text { Molybdenum } \\
\text { Carbon }\end{array}$ & $\begin{array}{l}54.9 \\
30.0 \\
4.5 \\
3.0 \max \\
3.0 \max \\
2.0 \max \\
1.5 \max \\
1.1\end{array}$ & 7.8 & $R_{B} 97-100$ \\
\hline $\begin{array}{l}\text { Stellite } 6 \mathrm{H} \\
\text { (hard facing) }\end{array}$ & $\begin{array}{l}\text { Cobalt } \\
\text { Chromium } \\
\text { Tungsten } \\
\text { Carbon }\end{array}$ & $\begin{array}{l}66.9 \\
28.0 \\
4.0 \\
1.1\end{array}$ & 8.7 & $R_{C} 27-30$ \\
\hline
\end{tabular}


TABLE 1

COMPOSITION, THERMAL EXPANSION, AND HOT HARDNESS OF

CANDIDATE MATERIALS

(Sheet 11 of 14)

\begin{tabular}{|c|c|c|c|c|}
\hline Material & Comp & sition & $\begin{array}{c}\text { Mean } \\
\text { Coefficient of } \\
\text { Thermal } \\
\text { Expansion } \\
(\text { from } 70- \\
\left.1200^{\circ} \mathrm{F}\right) \\
\left(\mu \text { in. } / \text { in. } /^{\circ} \mathrm{F}\right)\end{array}$ & $\begin{array}{l}\text { Hardness } \\
\left(\text { at } 1200^{\circ} \mathrm{F}\right)\end{array}$ \\
\hline $\begin{array}{l}\text { Stellite } 1016 \\
\text { (hard facing) }\end{array}$ & $\begin{array}{l}\text { Cobalt } \\
\text { Chromium } \\
\text { Tungsten } \\
\text { Carbon }\end{array}$ & $\begin{array}{l}48.5 \\
32.0 \\
17.0 \\
2.5\end{array}$ & 7.2 & $R_{C} 39-41$ \\
\hline $\begin{array}{l}\text { Stellite Star J } \\
\text { (cast) }\end{array}$ & $\begin{array}{l}\text { Cobalt } \\
\text { Chromium } \\
\text { Tungsten } \\
\text { Iron } \\
\text { Nickel } \\
\text { Carbon }\end{array}$ & $\begin{array}{l}43.0 \\
32.0 \\
17.0 \\
3.0 \\
2.5 \max \\
2.5\end{array}$ & 7.2 & $R_{C} 39-41$ \\
\hline 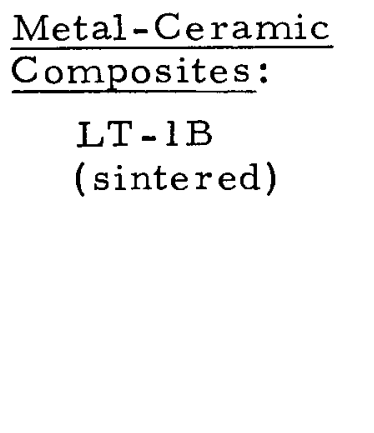 & $\begin{array}{l}\text { Chromium } \\
\text { Molybdenum } \\
\text { Aluminum } \\
\text { oxide } \\
\text { Titanium } \\
\text { oxide }\end{array}$ & $\begin{array}{l}59.0 \\
20.0 \\
19.0 \\
2.0\end{array}$ & $\begin{array}{c}4.7 \\
(\text { from } 77- \\
\left.1832^{\circ} \mathrm{F}\right)\end{array}$ & \\
\hline $\begin{array}{l}\mathrm{LT}-2 \\
\text { (sintered) }\end{array}$ & $\begin{array}{l}\text { Tungsten } \\
\text { Chromium } \\
\text { Aluminum } \\
\text { oxide }\end{array}$ & $\begin{array}{l}60.0 \\
25.0 \\
15.0\end{array}$ & $\begin{array}{c}4.7 \\
(\text { from } 77- \\
\left.1832^{\circ} \mathrm{F}\right)\end{array}$ & \\
\hline
\end{tabular}


TABLE 1

COMPOSITION, THERMAL EXPANSION, AND HOT HARDNESS OF CANDIDATE MATERIALS

(Sheet 12 of 14)

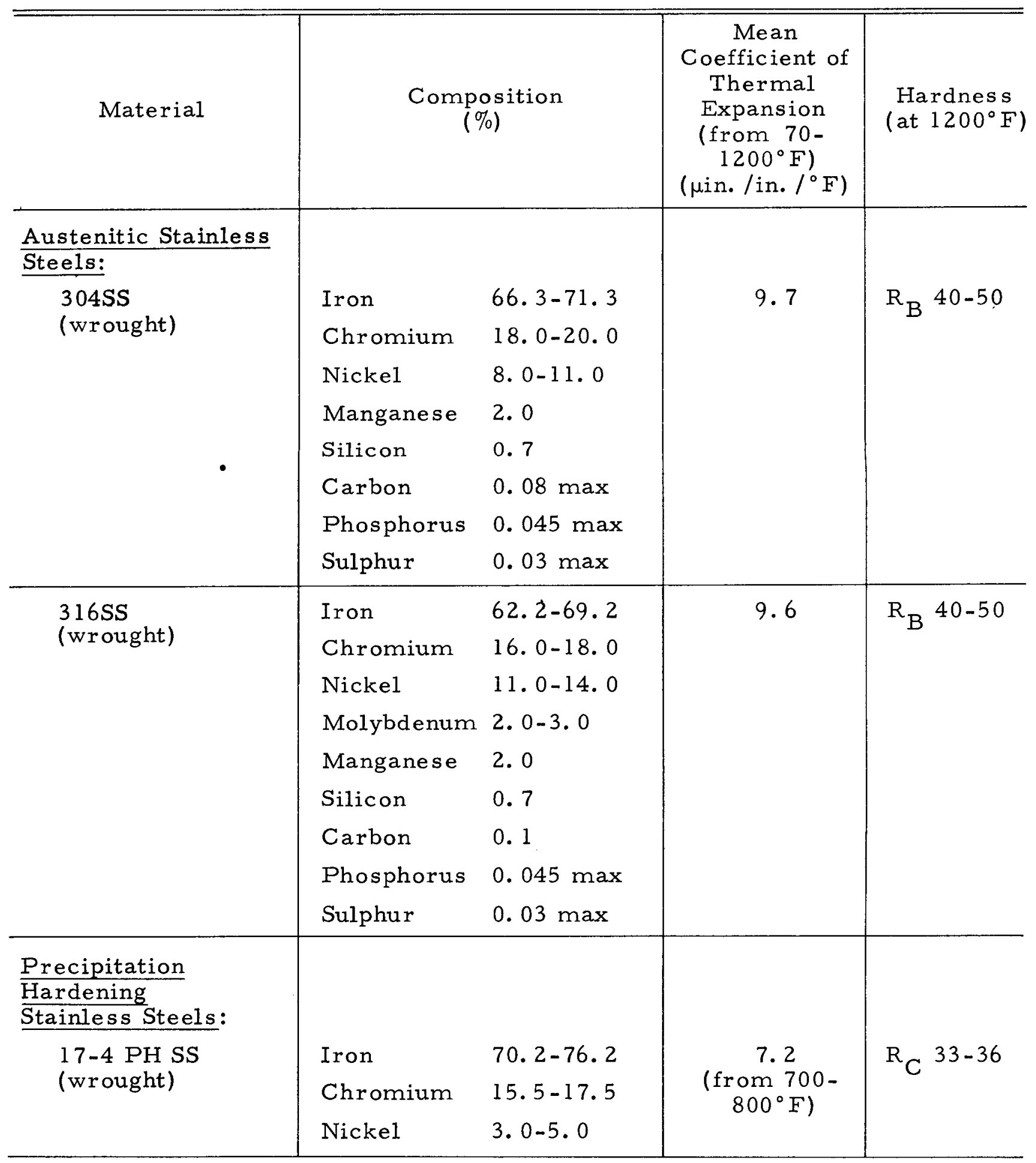


TABLE 1

COMPOSITION, THERMAL EXPANSION, AND HOT HARDNESS OF CANDIDATE MATERIALS

(Sheet 13 of 14)

\begin{tabular}{|c|c|c|c|c|}
\hline Material & Com & o) & 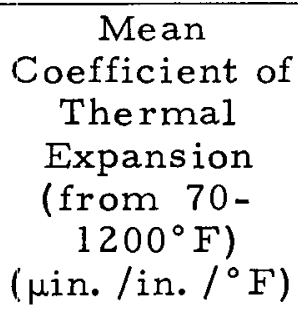 & $\begin{array}{l}\text { Hardness } \\
\left(\text { at } 1200^{\circ} \mathrm{F}\right)\end{array}$ \\
\hline 17-4 PH SS (cont) & $\begin{array}{l}\text { Copper } \\
\text { Silicon } \\
\text { Manganese } \\
\text { Carbon } \\
\text { Niobium* } \\
\text { * Contains } \\
\text { amount ta }\end{array}$ & $\begin{array}{l}3.0-5.0 \\
1.0 \mathrm{max} \\
1.0 \mathrm{max} \\
0.07 \mathrm{max} \\
0.30 \\
\text { all } \\
\text { alum }\end{array}$ & & \\
\hline $\begin{array}{l}\text { 17-7 PH SS } \\
\text { (wrought) }\end{array}$ & $\begin{array}{l}\text { Iron } \\
\text { Chromium } \\
\text { Nickel } \\
\text { Manganese } \\
\text { Silicon } \\
\text { Aluminum } \\
\text { Carbon }\end{array}$ & $\begin{array}{l}72.9 \\
17.0 \\
7.1 \\
1.0 \max \\
1.0 \max \\
1.0 \\
0.09 \max \end{array}$ & $\begin{array}{c}6.6 \\
(\text { from } 70- \\
\left.800^{\circ} \mathrm{F}\right)\end{array}$ & $R_{C} 27-29$ \\
\hline $\begin{array}{l}\text { Ceramics: } \\
\text { Coors } \\
\text { AD-995 } \\
\text { (cast) }\end{array}$ & $\begin{array}{l}\text { Alumina } \\
\left(\mathrm{Al}_{2} \mathrm{O}_{3}\right.\end{array}$ & 99.9 & $\begin{array}{c}4.3 \\
(\text { from } 77- \\
\left.1100^{\circ} \mathrm{F}\right)\end{array}$ & $R_{C} 36-40$ \\
\hline $\begin{array}{l}\text { Lucalox } \\
\text { (cast) }\end{array}$ & $\begin{array}{l}\text { Alumina } \\
\left(\mathrm{Al}_{2} \mathrm{O}_{3}\right)\end{array}$ & 99.9 & $\begin{array}{c}4.3 \\
(\text { from } 77- \\
\left.1100^{\circ} \mathrm{F}\right)\end{array}$ & $R_{C} 36-40$ \\
\hline $\begin{array}{l}\text { Copper-Base Alloy: } \\
\text { AMPCO } \\
18-13\end{array}$ & $\begin{array}{l}\text { Iron } \\
\text { Aluminum } \\
\text { Copper }\end{array}$ & $\begin{array}{l}3.4-4.0 \\
10.6-11.2 \\
86-84.8\end{array}$ & $\begin{array}{l}\sim 13.8 \\
\left(\begin{array}{c}\text { from } 77- \\
\left.900^{\circ} \mathrm{F}\right)\end{array}\right.\end{array}$ & \\
\hline
\end{tabular}


TABLE 1

COMPOSITION, THERMAL EXPANSION, AND HOT HARDNESS OF CANDIDATE MATERIALS

(Sheet 14 of 14)

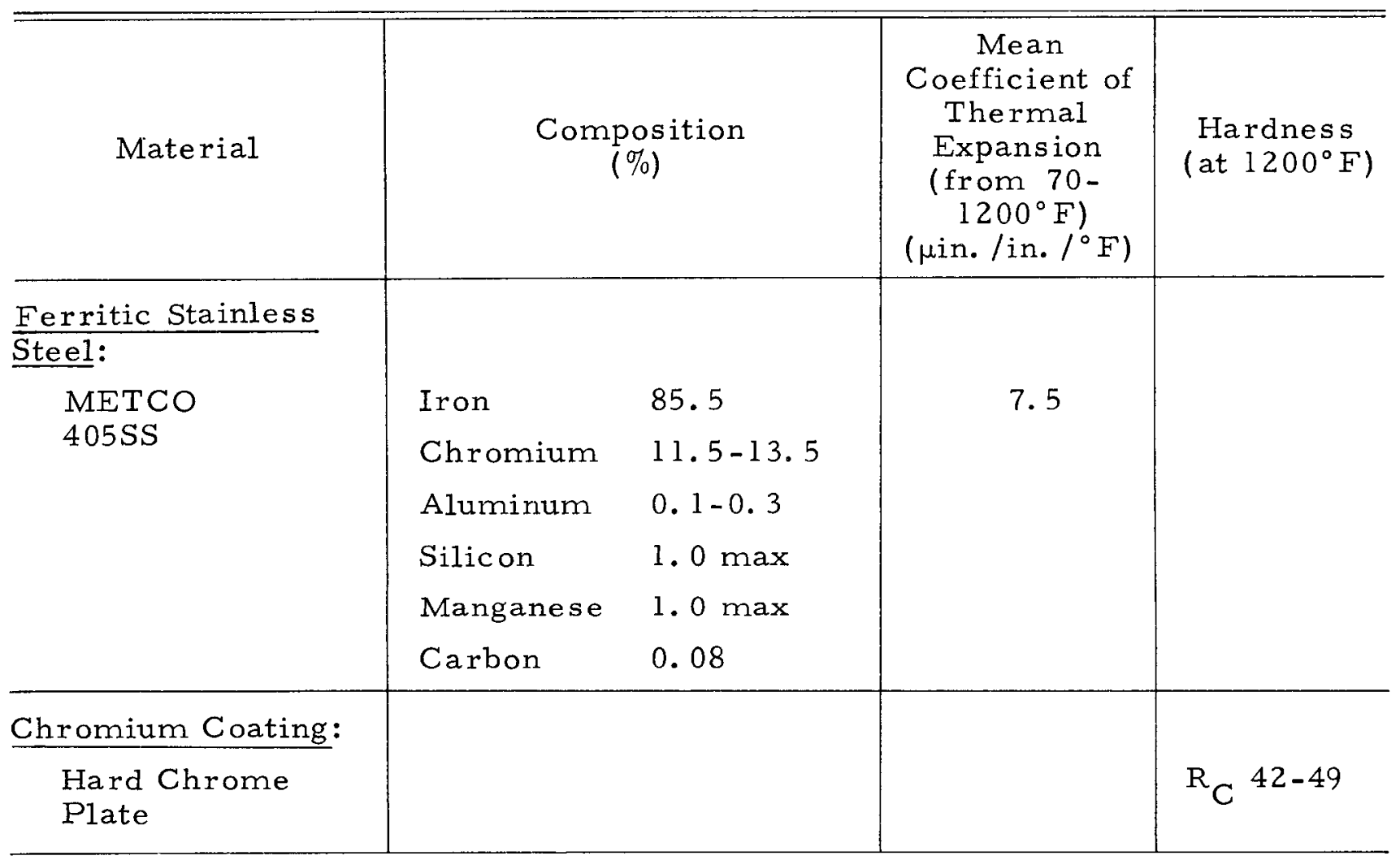

Below $\mathrm{T}_{1}$, the lubricative complex is stable in $15 \mathrm{ppm} O$ sodium. If the sodium contained $100 \mathrm{ppm}$, the lubricative oxide would be stable to $\mathrm{T}_{2}$. In sodium saturated with $O$, the lubricative oxide is stable to $\mathrm{T}_{3}$. Conversely, at any temperature below $\mathrm{T}_{3}$, the oxygen content of the sodium should adjust itself until it reaches a ppm level with equivalent chemical potential ${ }^{*}$ to that of the oxygen in the polyoxide. For actual values of these curves for certain metals see References 3 through 5. The actual values for the elemental metals are not exactly what the designer needs since the activity of an element in an alloy is not unity and, therefore, the free energy relationships are slightly changed.

\footnotetext{
*Two solutions are in equilibrium with each other when the "chemical potential" of each component in the two solutions have equal values. The chemical potential includes a term giving the free energy at an assumed standard state and a term that includes the natural $\log$ of the "activity" of the component being considered. The activity is roughly equal to the ratio of the actual concentration of the component to its concentration at saturation.
} 


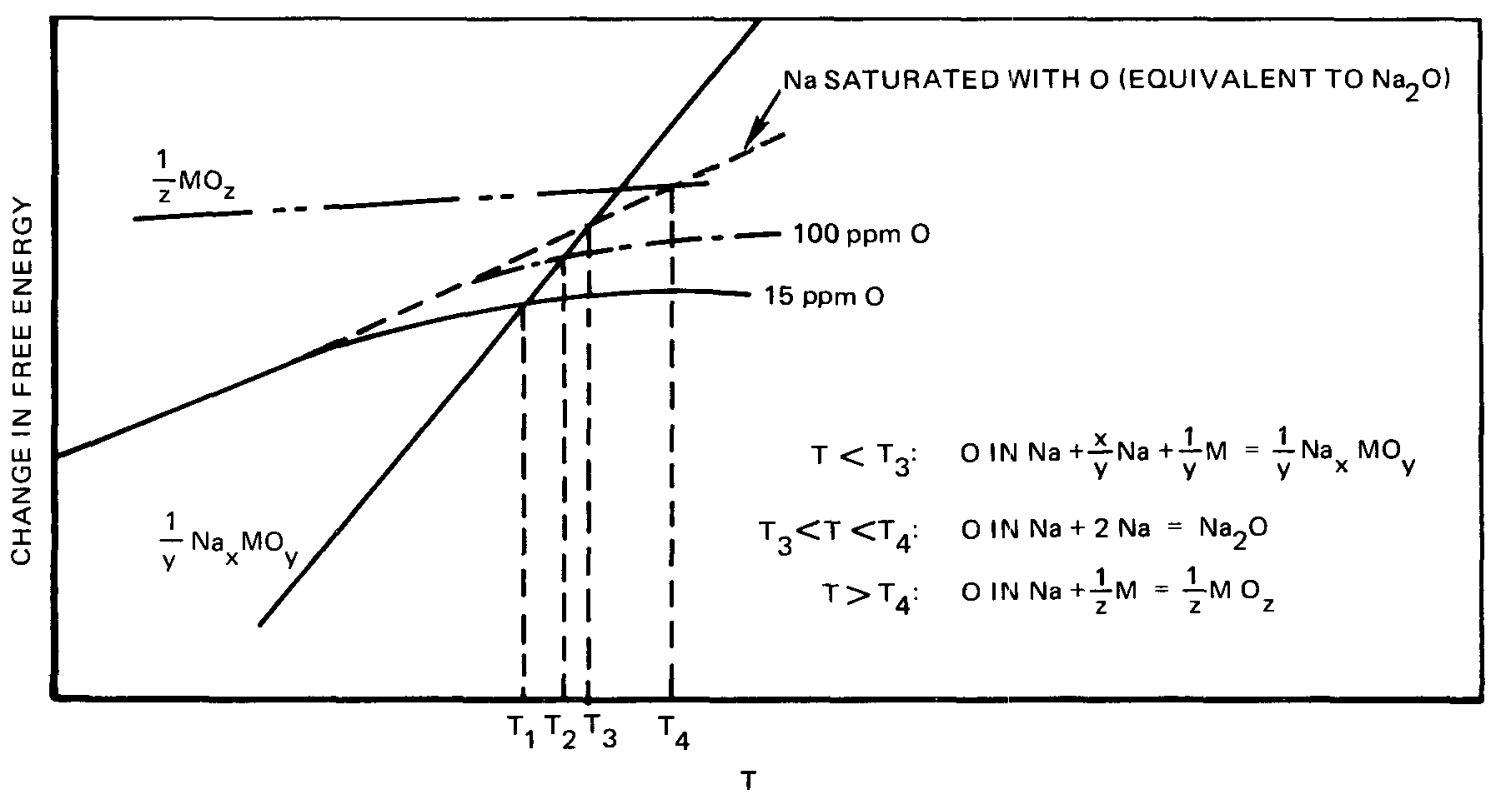

$7693-4728$

Figure 1. Free Energy as a Function of Temperature

The important point for the designer to remember is that a $\mathrm{T}_{1}, \mathrm{~T}_{2}, \mathrm{~T}_{3}$, and $\mathrm{T}_{4}$ exist for each system, so wear behavior does not change uniformly with temperature but has ranges of temperature within which a particular behavior occurs.

\section{Radiation Damage}

Bearings intended to operate in a strong radiation field should not include materials known to be susceptible to radiation damage. Two common effects of radiation damage, swelling and embrittlement, would act to hasten failure of the bearing. Boron compounds, valuable for the hardness they impart to a bearing material, would be an example of an undesirable material if they are to be exposed to a neutron flux that would cause the boron-to-helium transformation. The Colmonoy alloys, in particular, have a high boron content, so the. designer must pay attention to the neutron flux level when contemplating use of these alloys.

\section{Thermal Conductivity}

A high thermal conductivity will dissipate frictional heat more rapidly, minimizing the alloying tendency at points of interfacial contact and preventing mechanical damage from local overheating. Liquid metal lubricants can help 
to make up for a low thermal conductivity in an otherwise desirable bearing material by their excellent heat transfer characteristics.

\section{Thermal Expansion Coefficient}

The thermal expansion characteristics of the complete mechanical element assembly must be carefully considered if the small clearance designs required with low-viscosity liquid metal lubricants are to be successful. The element must have proper fit and clearance both at room temperature and at the selected operating temperature. If the element is operated above its design temperature, care must be taken that a proper clearance still exists. Use of only one material in a bearing couple, of course, minimizes the potential thermal expansion mismatch, but here again the bearing material must be matched carefully with the structural material of the assembly.

Thermal expansion problems increase as the size of the mechanical element increases. Use of a thin coating of bearing material on a base metal as the rubbing surface in an otherwise monometallic element minimizes this difficulty. Here the thermal expansion coefficients of coating and base must be matched to prevent loss of bonding during thermal cycling.

Values of thermal expansions are given in Table 1.

\section{Transmutation to a Radioactive Source}

Material leached from bearing surfaces will be transported throughout the system, and may deposit out of the sodium in undesirable locations. The amount of such materials will be very small in comparison with the total volume of sodium and containment metals in the system; but if it has become radioactive during its exposure in the bearing, it will transport this radioactivity in amounts that could be substantial. Cobalt, which is commonly used in bearings, is one element that might cause such a problem. If a bearing surface is to be exposed to significant radiation during its lifetime, its corrosion characteristics and the radioactivity of its corrosion products should be evaluated to determine if a problem will exist because of radioactive material transfer. For example, radioactive cobalt deposited on pump parts may prevent any planned pump disassembly in a primary loop. In particular, if the pump is to be in the cold leg, significant areas of cobalt alloys might prove troublesome because of the mass transfer. Actual wear debris from cobalt alloys, such as the Stellites, might prove awkward even for pumps located in the hot leg.

\section{LMEC- $70-10$}




\section{B. MATERIAL CLASSES \\ 1. Nonrefractory Metals and Alloys}

As a broad class, the nonrefractory metals, high strength steels, and super alloys have lower temperature limitations than the other material classes considered here. Within their temperature limitations, however, these materials exhibit many attractive combinations of properties. With these materials, it is possible to have high strength and hardness - both very desirable for liquidmetal-lubricated rubbing surfaces - and yet retain significant ductility and ability to deform plastically without cracking. Their corrosion resistance varies with the chemistry and, of course, with temperature; but it may be rated in general as good. Mass transfer properties in particular must be considered for the overall liquid metal system. Fabrication is the simplest of any of the material classes, properties are well known and reproducible, and theoretical density (zero porosity) is attained easily.

The nickel and cobalt super alloys have the highest temperature potential; cobalt-base alloys have demonstrated superior corrosion resistance. The highstrength tool steels represent the hardest materials of the metal alloys reviewed, although their use temperature must be kept below $1000^{\circ} \mathrm{F}$, where corrosion resistance, dimensional stability, and hot hardness are considered good. Above $1000^{\circ} \mathrm{F}$, one or more of these properties can be expected to deteriorate rapidly.

\section{Refractory Metals and Alloys}

Except for hardness, the advantages offered by the nonrefractory metals and super alloys are also found in this class of materials. While the hot hardness values of the refractory metals and alloys are lower at nominal liquidmetal-system bulk temperatures of 1000 to $1200^{\circ} \mathrm{F}$ then those of high-strength steels or super alloys, highly localized overheating at metal-to-metal contact points could raise the temperature where wear is occurring to the point where the hot hardness and strength of the high-melting-point refractory metals would be superior.

Refractory metal alloys (that do not contain oxygen getters such as zirconium) may form complex oxides with sodium that serve as lubricants within a certain temperature range. This fact makes molybdenum and tungsten interesting candidates for rubbing surface applications.

\section{LMEC - 70- 10}


A further result of this discovery of the complex oxide lubricant is the attempt to improve friction and wear characteristics of other bearing materials such as Stellites, tool steels, and bonded carbides by adding nominal amounts of molybdenum or tungsten.

\section{Carbides}

The carbides of the IV-A (Ti, etc.), V-A (Ta, etc.), and VI-A (Mo, etc.) transition metals have many of the properties considered desirable in bearing materials. Their thermal conductivity properties approach those of pure metals. They have high hardnesses, high compressive strengths, and high elastic moduli. Their melting points are the highest of any of the material classes. Their resistance to alkali metal corrosion is satisfactory, although it may be affected by fabrication processes that introduce impurities or porosities; intergranula $\mathbf{r}$ impurity leaching may then lead to mechanical damage.

The primary concern with carbides is their brittleness, susceptibility to impact loading damage, and extreme abrasiveness of any debris produced by such damage. From a fabrication standpoint, the problem is the inability to achieve high densities (close to theoretical), which results in a (comparatively) rough surface. It is argued that such a porous surface may have some value in its ability to absorb or imbed debris particules that otherwise would cause scoring, but this has not been demonstrated empirically.

As a class, the binderless carbides have less appeal than the well developed bonded carbides. However, progress of recent attempts to produce a thin carbide bearing surface in situ on the shaft or journal by surface treatment ${ }^{(6)}$ offers some hope of realizing the desirable properties of the carbides without the undesirable features present in monolithic specimens.

\section{Bonded Carbides}

The commercially produced bonded carbides used commonly in cutting tools are designed to overcome the two serious faults of pure carbides; brittleness and porosity. They retain the high compressive strength, hardness, elastic modulus, and thermal conductivity of the carbides and add the desirable feature of excellent commercial status. Good corrosion resistance to liquid metal environments has been demonstrated, but this property will vary with the bonding agent. 
Iron, nickel, and cobalt are the metals most commonly used as bonding agents; carbides of tungsten, titanium, tantalum, chromium, and niobium are used alone or in combination. According to Kieffer, ${ }^{(7)}$ the action of the bonding agent is to form an alloy network between the hard crystals of carbide. The success of the iron group as bonding agents stems from the fact that there is some solubility of the carbide in these bonding agents at the sintering temperatures used to prepare the materials; alloying of the bonding agent and carbide occurs to form a eutectic liquid phase that solidifies to a tough matrix. Liquidphase sintering also provides the theoretical density so difficult to achieve with pure carbides. Sykes ${ }^{(8)}$ has further shown that the metallographic structure of cobalt-bonded tungsten carbide is changed significantly when titanium carbide is added; a reaction between the carbides and the cobalt produces a new phase that ties up much more of the bonding agent in solution or as a complex intermetallic compound. Coffin ${ }^{(9)}$ correlated this change in character of the bonding matrix with the observed improved performance when cutting steel of cutting tools made of the mixed carbides over tools of tungsten carbide. He further observed that the wear resistance of the mixed carbide material used as a bearing surface in sodium was better than that of the material containing only tungsten carbide. He concluded that bearing wear was caused by alloying of the bonding agent in the bonded carbide with the metal of the other rubbing surface, and that wear would be decreased by: (1) reducing the amount of free bonding agent, as by tying it up with titanium carbide additions; and (2) selecting a metal for the surface rubbing on the carbide that had a low solubility in the bonding agent.

Because the major limitation in the use of bonded carbides in hightemperature liquid metals was expected to be the corrosion resistance of the bonding agent, the natural extrapolation was to replace the iron group bonding agents with refractory metals. Tantalum, tungsten, molybdenum, and niobium have all been used successfully in experimental formulations. These materials proved to have increased resistance to corrosion and mass transfer in liquid metal systems and higher temperature capabilities than carbides bonded with cobalt, iron, or nickel. Wallace ${ }^{(6)}$ concluded that refractory-metal-bonded carbides probably have the best potential as materials for alkali-metallubricated journal bearings. The greatest drawback to these materials is the limited data available on fabrication techniques and mechanical properties.

LMEC-70-10 
Use of molybdenum and tantalum also provides an opportunity for improved boundary lubrication characteristics by formation of the complex sodium-metaloxide surface film reported by Kissel. (10) It is not yet clear whether the chemistry of the refractory metal in its role as a bonding agent in bonded carbides will allow formation of the complex oxide.

\section{Other Materials}

\section{a. $\quad$ Oxides}

Ceramic oxides have high hardnesses, high compressive strengths, high elastic moduli, and satisfactory corrosion resistance in alkali metals. High densities, close to theoretical, are easily achieved. Beryllium oxide has good thermal conductivity, but a higher chemical reactivity than alumina. The greatest drawback to successful operation of oxide rubbing surfaces is, like carbides, their brittleness.

\section{b. Borides}

The general observations on carbides also apply to borides. Much less information on properties and experimental behavior is available for borides.

\section{c. Nitrides}

As a class, the nitrides are less promising than carbides or borides because of their high vapor pressures, lower hardnesses, and producibility problems. Neither borides nor nitrides show the potential for any exceptional advantage over carbides that might warrant a development program to bring them to the same state of knowledge as carbides.

\section{d. Surface Coating Materials}

Treatments used to apply a thin coating of bearing material on the surface on nonbea ring-material substrate will be considered as a separate class. While the corrosion, friction, and wear properties of the material will be the same as for bulk specimens, the thermal properties of the composite, and the fabrication processes to form the composite, are different enough to place the composite in a separate class. Flame spraying or plasma spraying is commonly used to apply refractory metals, carbides, bonded carbides, and oxides to an almost unlimited range of substrate alloys. Carburization and nitriding produce cases 
of essentially pure carbides or nitrides on selected substrate alloys. By using surface coatings, the material for the mechanical device may be chosen for its strength, toughness, thermal expansion characteristics, or fabricability; the desired friction and wear properties are then produced by adding a coating of bearing material with the correct bearing properties for the design environment.

While surface treatments seem to offer the best features of wear resistance and base metal ductility, they are beset with problems, peculiar to the class, that have kept them in a developmental stage, behind the state of knowledge of the parent bearing materials. The problem of producing a satisfactory permanent bond holding its integrity through thermal and mechanical shocks is paramount. Achieving the full density required for satisfactory performance of any bearing material is often difficult. Maintaining the chemistry of the parent material during the surfacing operation is essential to success of the composite, and yet is not accomplished easily. Finally, reproducibility of the surfacing process must be raised to the same level as that of the fabrication of monolithic pieces before reliable performance can be obtained.

Because the difficulty of building bearings from monolithic blocks of bearing materials increases greatly as the size of the bearing increases, it is probable that the very large bearings contemplated for Liquid Metal Fast Breeder Reactor (LMFBR) pumps will be surface-coated. Successful commercialization of the process would also provide improved performance in smaller bearings where thermal expansion mismatches between bearings and structures have caused design problems. 


\section{MECHANICAL CONSIDERATIONS}

For the Liquid Metal Fast Breeder Reactor (LMFBR) program, it is assumed that mechanical devices, such as pump bearings, fuel handling equipment, and control rod drives, will be required to operate in a sodium environment at temperatures up to $1200^{\circ} \mathrm{F}$ for extended lifetimes. Operation may be continuous or intermittent, but in either case must be highly reliable. The use of sodium as a lubricant causes several problems that a re not normally encountered in conventionally lubricated bearings. Liquid metal viscosities are very low, compared with those of conventional lubricants, so that the allimportant lubricating film thickness that can be obtained with liquid metals is very small, making surface-to-surface contact much more probable. Since the load-carrying capacity of a bearing is dependent on the viscosity of the lubricant, bearings lubricated with low-viscosity liquid metal must be carefully designed to keep the loading low. Where conventional lubricants may provide boundary lubrication by forming an adsorbed or chemical reaction film on the metal surface, sodium may prevent film lubrication by reacting with and dissolving protective surface films and promoting metal-to-metal contact. Where conventional lubricants have been replaced by surface coatings or simple surface films such as oxides that give satisfactory high-temperature lubrication, sodium not only may remove such a coating under certain conditions, but may prevent its reformation, again promoting metal-to-metal contact. The materials used must be completely compatible with the sodium, because any corrosion or dissolution by the sodium will cause surface damage that will have the same effect as mechanical wear, acceleration of wear rates, and early failure.

The several types of bearings in general use are discussed in this section, with the influence that the sodium environment has on their operating characteristics.

\section{A. HYDRODYNAMIC BEARING}

In the hydrodynamic fluid film bearing, a continuous film separates the sliding surfaces during operation; the pressure required to support the load is generated within the bearing itself, and the only external pressure is that required to feed enough lubricant into the bearing to maintain a full fluid film. 
Conventionally lubricated hydrodynamic bearings can tolerate some wear if surface damage is not extensive. However, with liquid metal as a lubricant, its low viscosity demands bearings designed with a very small clearance, and the tolerance for wear decreases to the vanishing point.

Some disadvantages of the plain hydrodynamic bearing are its inherent instabilities under light load conditions, its nonaligning characteristics, and the small flow of lubricant that may not remove friction-generated heat from bearing surfaces fast enough. Rotor shaft systems can exhibit several forms of dynamic instabilities: shaft whirl, shaft whip, and resonant vibration. These all have a basic pattern in which the shaft center tends to rotate in an orbit within the bearing clearance. If the amplitude of this orbit becomes large enough, equal to the radial clearance in the bearing, solid contact is made between shaft and bearing, and failure results. Here, the liquid-metal-lubricated bearings are at a severe disadvantage when compared with conventionally lubricated designs; the bearing clearance is so small in liquid metal designs that essentially no instability can be tolerated if the journal and bearing a re to be kept from touching at high speeds.

These instabilities have been analyzed and controlled for fluid-film bearings operating with laminar flow in the clearance space. Plain journal bearings have been modified into variations, such as the Rayleigh-step, elliptical-journal, pocket-journal, tilting-pad, and floating-ring designs, that can be self-aligning and that do overcome the inherent instability problem to some degree. However, different analytical and design techniques must be used when turbulent conditions prevail in the lubricant films. With high-speed operation and low-viscosity liquid metal lubricants, turbulent flow in fluid-film bearings presents a new set of problems. The load-carrying capacity of a bearing increases when the change from laminar to turbulent flow in the lubricant film occurs, but the bearing power consumption (friction) rises even more sharply. Recorded bearing torques in the turbulent region have been 4 to 40 times as great as predicted by laminar theory. (11) Since the lubricant flowrate also decreases in the turbulent region, the problem of frictional heat removal is aggravated. Two reports dealing with the development of a theory of turbulent lubrication in small high-speed mercurylubricated bearings have been published by Arwas. $(12,13)$

LMEC - 70- 10 
A third report by Elrod et al. ${ }^{(14)}$ presents a theory for turbulent lubrication and for rotor-bearing dynamics of flexible high-speed rotors supported in turbulent-flow bearings lubricated with low-kinematic-viscosity fluids. These theories may be reviewed for their applicability to small, very high-speed bearings lubricated with alkali metals, such as are required in the rotating converter units of nuclear electric power systems in space.

Another serious disadvantage of the hydrodynamic bearing is its poor loadcarrying ability at low speeds. A conventional bearing depends on boundary lubrication to protect the bearing surfaces at startup and while the shaft is coming up to design speed. Liquid metal lubricants may have no film lubrication properties, and the bearing materials must be extremely wear-resistant if they are not to be severely damaged during startup and low-speed operations.

\section{B. HYDROSTATIC BEARING}

In the hydrostatic fluid film bearing, complete separation of the surfaces in relative motion is maintained by a continuous fluid film, but the loadsupporting pressures are supplied from an external pressure source, and may be as high as needed for optimum bearing design. The hydrostatic bearing of fers relative freedom from the instabilities inherent in hydrodynamic bearings; it has a load capacity independent of lubricant viscosity, and it has a high loadcarrying capacity at no rotation, startup, and low-speed operation. Wear of bearing surfaces is thus minimized.

However, the high load capacity is achieved at the expense of providing a separate external pressure source that complicates the system design considerably. A.flow restrictor is also required in the feed line between bearing and pressure source if the bearing is to function properly, and these restrictors are sensitive to both plugging and erosion. Lubricant flow through the bea ring is higher than in a hydrodynamic bearing, causing a higher parasitic power loss, but also providing improved temperature control.

When the hydrostatic bearing is to be used in a sodium pump, one compromise that can be made to avoid the complication of a separate pressure source is to use the pump's own discharge to pressurize the bearing. The advantage of high load capacity is still operative at design speeds, and a smaller bearing area may be used. But the load capacity falls off rapidly as pump speed 
decreases, and the bearing surfaces will come into contact at low speeds and at start-stop operation, just as in the hydrodynamic bearing. The pump system must be carefully designed, then, to keep the bearing load at start-stop and at low speeds to an absolute minimum.

The parasitic flow required to pressurize such a bearing for an LMFBR pump has been estimated at $7 \%$ of the total pump discharge. ${ }^{(15)}$ If the bearing is designed with larger clearances to prevent contact at the lowest operating speed, the size of the bearing becomes larger and the parasitic flow increases sharply. Design parameters for such a unit must be carefully traded off if the optimum bearing performance is to be achieved.

Recently, the use of a hydrostatic self-aligning bearing has been proposed (16) to minimize the radial clearance necessary in hydrostatic bearings, and thereby to decrease the power loss due to bearing flow requirements to an estimated $1-1 / 2 \%$ of full pump flow. The required bearing diameter is also significantly smaller.

\section{ROLLING-ELEMENT BEARINGS}

For a rolling-element bearing to function properly, there must be no wear or surface degradation of the rolling element or races. Surface damage of any kind results in rough operation which further accelerates wear and leads to complete failure. The combination of high-pressure contact between rolling element and race (because of the small contact area) and the poor conformity of these contacting surfaces discourages the formation of a hydrodynamic film of lubricant. Such a film would prevent the intimate contact of these surfaces that results in surface welding of contacting asperities, material transfer from one surface to another, wear, and ultimately bearing failure.

Successful operation of rolling-element bearings has been achieved in applications for conventional environments where conventional lubricants may be used. Theories for formation and maintenance of an elastohydrodynamic lubricant film have been developed and correlated with observed wear patterns. One such experimental and mathematical study ${ }^{(17)}$ of elastohydrodynamic film formation in a rolling-ball test apparatus showed that significant wear occurred only when the film was interrupted, and that wear become progressively more rapid as the severity of asperity contacts increased. This emphasizes the importance of maintaining an unbroken lubricant film to prevent wear in rolling contact.

\section{LMEC- $70-10$}


For the LMFBR program it is assumed that mechanical devices, such as fuel handling equipment and control rod drives, will be required to operate in an environment of liquid sodium, or sodium vapor plus an inert cover gas, at temperatures up to $1200^{\circ} \mathrm{F}$ for extended lifetimes. Operation may be continuous or intermittent, but in either case must be highly reliable.

The special problems caused by sodium environments a re especially severe in rolling-element bearings, where high pressures exist in the contacts between rolling elements and races even under light loads. Low viscosity and high chemical reactivity of the sodium coolant may tend to keep the film bearing capacity low, so that the bearing must be carefully designed to keep the unit loading low. Corrosion damage to a bearing surface is more likely to cause trouble than in a journal bearing because the area of contact is smaller. Because of the severity of these problems, early workers recommended ${ }^{(18)}$ that rolling element bearings not be considered for high-load continuous service, although they were still considered useful in intermittent-use, light-load applications.

\section{BOUNDARY LUBRICATION OF SURFACES}

Where surfaces in relative motion move too slowly to build up hydrodynamic lubricant film between them, and where no external pressure source is used to supply a lubricant film, the two surfaces will be forced into contact by the applied load and will suffer wear. With conventional lubricants, an adsorbed lubricant film may cling to the rubbing surface, or a chemical reaction film (usually oxide) may have formed on the rubbing surface; any such film will tend to prevent the clean metal contacts that weld, then break, causing wear. Special lubricating films may be applied to rubbing surfaces to perform the same service. With alkali metals, no such deliberately applied films are presently available; the liquid metal, under certain conditions, can dissolve or reduce surface films that may be present and, in addition, may fail to provide an adsorbed film of beneficial thickness because of its low viscosity.

Liquid metals, then, may, under certain conditions, promote metal-tometal contact and severe wear of rubbing surfaces. Mechanical elements that must be used in liquid metals in the boundary lubrication regime should be designed with the following tenets in mind to minimize viear:

\section{LMEC - 70- 10}


1) The bearing surfaces should be large enough to keep bearing loads low, but above $\sim 100$ psi.

2) Materials in a rubbing couple should be chosen to have minimum adhesive wear tendencies.

3) Clearances should be as large as possible without impairing the mechanical function of the element.

4) Surface finishes of the rubbing surfaces should be as high as possible to distribute the load over as much of the surface as possible.

5) Hardnesses should be high to minimize abrasive wear. 


\section{UTILIZATION OF DESIGN DATA}

The designer should be interested in both static test data and sliding contact results. The static data are the sources of quantitative information on "selfwelding." The sliding contact data are not only sources of quantitative wear values, but also of sliding coefficient of friction values. These latter coefficients often will exceed the initial static coefficient of friction values as sliding continues over long distances. This effect may be of more importance to the designer than either the "self-welding" static effect or the amount of wear occur ring during sliding.

A discussion of both static test and sliding contact test implications is given in the following sections.

\section{A. STATIC TEST DATA}

The designer can utilize the static test data reported here in two ways: (1) use the numerical value reported for those design calculations requiring static coefficient of friction data and (2) quantify the "self-welding" characteristics of a metal couple exposed, under pressure, to liquid sodium for long periods of time at temperature. In using these data for the latter purpose, the designer must realize that the reported values for coefficient of static friction after exposure are valid only for the pressure range within which the tests were conducted. This may seem surprising since the coefficient of friction is known to be independent of pressure. The self-welding characteristics after long-time, high-temperature exposure are partially dependent on the volume diffusion rates within the solid and the surface diffusion characteristics, both of which are pressure sensitive to some degree.

\section{B. WEAR IN SLIDING CONTACT}

In order to use the sliding contact data generated here, the designer must be aware of certain considerations that will greatly affect how he uses the data. These considerations are discussed in the following paragraphs.

\section{Wear Rate Coefficient}

Wear can be measured as the volume of material lost during rubbing or the depth worn away. The amount of material lost is obviously affected by the

\section{L.MEC-70-10}


distance over which rubbing occurred. Obviously, too, either the contact load or the contact pressure must affect the amount of wear. Experience tended to give the impression that the volume lost was directly proportional both to the distance traveled and the load applied. This concept meant that the volume lost per distance traveled, when plotted against load, would result in s straight line. The slope of this line would then be a constant characteristic of the two rubbing materials. This constant, called the wear coefficient and usually labeled "K, " is the parameter by which couples can be compared for their relative wear characteristics.

The units of the wear rate coefficient can be expressed in terms of either volume worn away or in depth of wear [e.g., (in. ${ }^{3} /$ in.)/lb or (in./in.)/psi, respectively]. Classically, the volume worn away has been used, and the wear process has been thought to be independent of the apparent area of wear. While the volume worn away is independent of area, the depth of wear is less when the pin area is greater. Thus, when the wear coefficient units are considered in terms of depth of wear, the pin area is important and is best inserted into the wear coefficient difinition by converting load to pressure.

One of the most important considerations concerning the wear coefficient is apparent from the perusal of actual typical wear-versus-load curves (see Figure 2). ${ }^{(19,20)}$

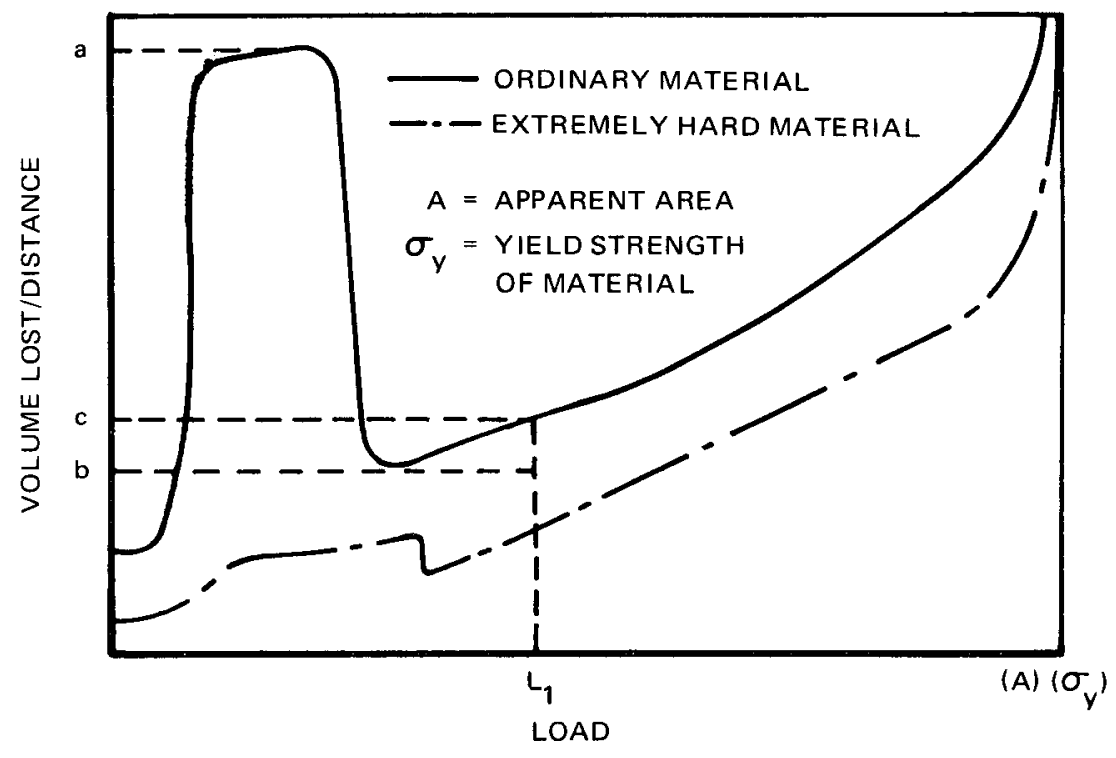

$7693-4729$

Figure 2. Curve Showing Typical Relationship Between Wear and Load 
The curve usually will show a minimum. If a test was run at load $L_{1}$, the volume worn away per unit distance traveled would be $c$ and the wear coefficient would be K. If the designer cuts the load in half, the wear might increase by the ratio of $\mathrm{a} / \mathrm{c}$. In the most extreme case, the wear at a lower load would be $\mathrm{a} / \mathrm{b}$ times the wear reported for load $L_{1}$. The ratio, $a / b$, ranges from just over unity to several orders of magnitude higher. ${ }^{19,20)}$ Thus, extrapolation of wear to different loads is often a dangerous procedure, particularly to lower loads. The designer may find it more useful to consider the abcissa and ordinate of Figure 2 as psi and in./in., respectively. With such coordinates the shape of the curve remains identical to that shown, and the $K$ value (the wear coefficient) retains the same numerical value as it had in the in. ${ }^{3} /$ in. load units. The reported $\mathrm{K}$ values in the literature and in this report represent the slope of a line from the origin to the (wear/distance traveled), (load) point of interest.

The values of $\mathrm{K}$ from this work are tabulated for the designer in Tables 2 and 3. The scatter is also shown in these tables." An example of the use of these tables by the designer is given in section $E$.

\section{Particulate Matter}

The wear rate coefficient is a function of more than just the two materials being rubbed. One of the most important additional parameters is particulate matter. This particulate matter is usually wear debris. These particles can penetrate into one or both of the rubbing surfaces and cause increased wear, up to some maximum value that is a function of the overall system. Systems should be designed so that entrained particulate matter will not sweep into the rubbing surfaces. Filters, regimes of low-flow velocity, and particulate matter traps should be considered in the system. The data reported here will not apply to those designs where particulate matter is a major factor.

\section{Oxygen Effects}

The effects of oxygen on rubbing surfaces in a sodium environment can be divided into two categories: (1) below-saturation effects and (2) $\mathrm{Na}_{2} \mathrm{O}$ solid effects. In below-saturation effects, the activity of oxygen is important both from the standpoint of possible oxidation-reduction reactions and the kinetics

*To convert from $\left(\mathrm{cm}^{3} / \mathrm{cm}\right) / \mathrm{kg}$ to (in./in.)/psi, divide by 14.2 .

\section{LMEC-70-10}


of metal transfer. The activity of oxygen in sodium is roughly equal to the ratio of the oxygen content to the saturation limit of oxygen in sodium. Thus, a change of a few ppm in oxygen content makes quite a difference when the saturation limit is, for example, $10 \mathrm{ppm}$, but very little difference when the limit is several thousand ppm. The low temperature range, then, is sensitive to small changes in oxygen level; while at $1200^{\circ} \mathrm{F}$, the activity is somewhat insensitive to fairly large changes in ppm oxygen.

The $\mathrm{Na}_{2} \mathrm{O}$ effects become extremely important in rubbing machinery operating under $500^{\circ} \mathrm{F}$ in sodium vapor. The sodium condenses on surfaces, picks up perhaps $50 \mathrm{ppm}$ oxygen from the cover gas, and, at the lower temperature, precipitates out a concrete-like $\mathrm{Na}_{2} \mathrm{O}$ deposit. This deposit can interfere with the operation of machinery. At high temperatures, the oxygen picked up from the cover gas will probably all be dissolved in the condensed sodium. The possibility of encountering the solid oxide formation is determined by the following three factors:

1) The distance away from bulk molten sodium.

2) The presence of baffle or encapsulating devices between the mechanism and the molten pool.

3) The temperature.

The effect of temperature on the solubility of oxygen is the key relationship required for estimating the type and extent of oxygen problem that the designer will encounter. This relationship is shown in Figure 3.

\section{Temperature Effects}

Since oxides and polyoxides often act as lubricants that cut down wear, the extent of the temperature regime in which the oxides are stable becomes a vital parameter. A significant change in wear behavior from within such a temperature regime to beyond it could occur within a few degrees change in temperature. For metals that may form a Na${ }_{2} \mathrm{CrO}_{4}$ coating, the transition temperature appears to be between 900 and $1200^{\circ} \mathrm{F}$. Above this transition temperature, wear is more severe.

In many cases, the polyoxides or oxides are stable at high temperatures but not at low temperatures. In such cases, wear is low in the high-temperature regime.

\section{LMEC-70- 10}



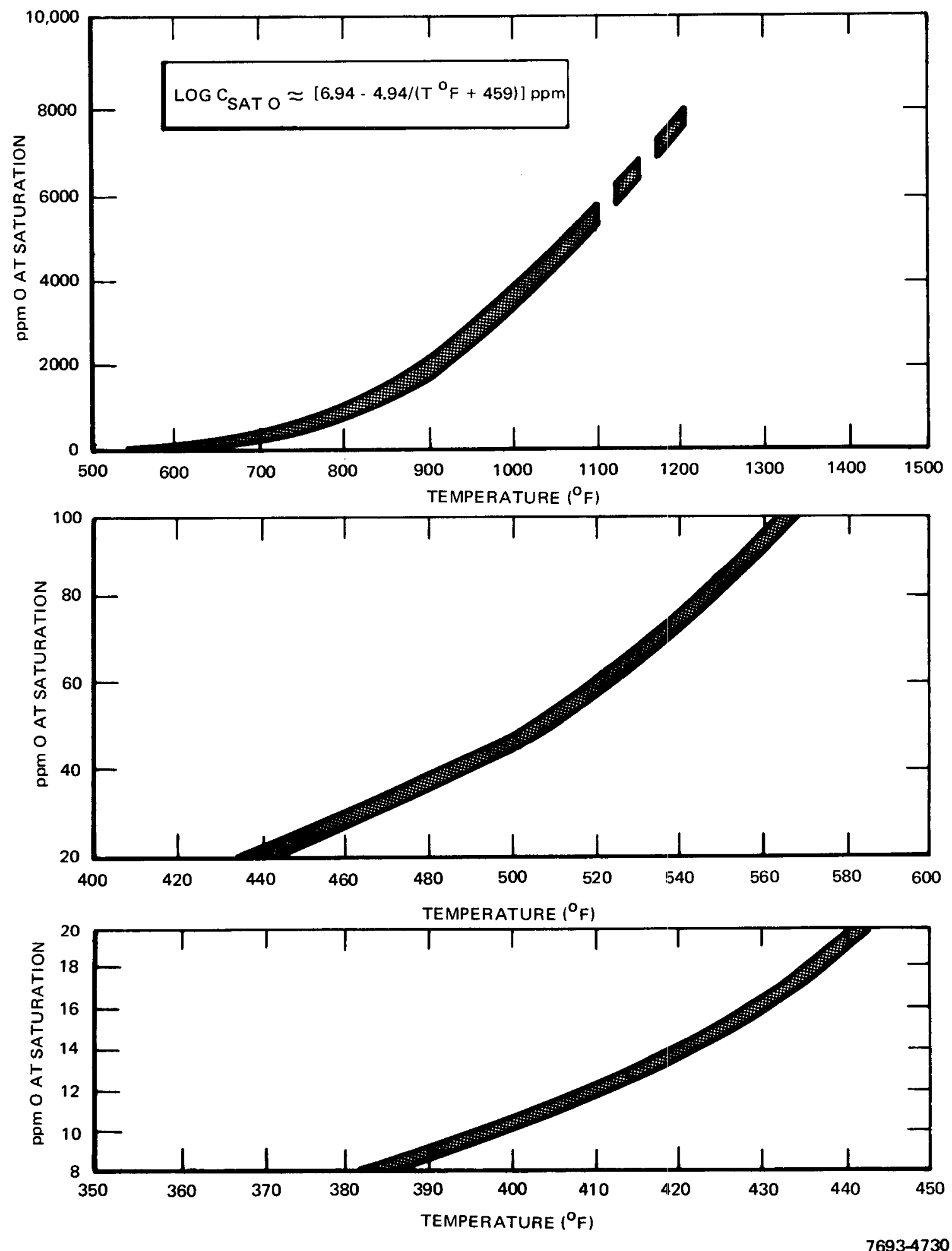

Figure 3. Approximate Oxygen Saturation Values as a Function of Temperature

\section{LMEC-70- 10}


The designer using these data should not extrapolate wear data to different temperatures. In particular, data or alloys containing chromium run in sodium at $900^{\circ} \mathrm{F}$ may not be valid for $950^{\circ} \mathrm{F}$ operation, for example, nor may the reverse be true.

\section{Distance Traveled}

The use of a wear coefficient implies that the rubbing surface wears linearly with distance traveled. When a sliding system contains a limited number of recycling abrasive particles, the most probable relationship between wear and distance traveled is that shown in Figure 4, which would describe a "wearingin" process.

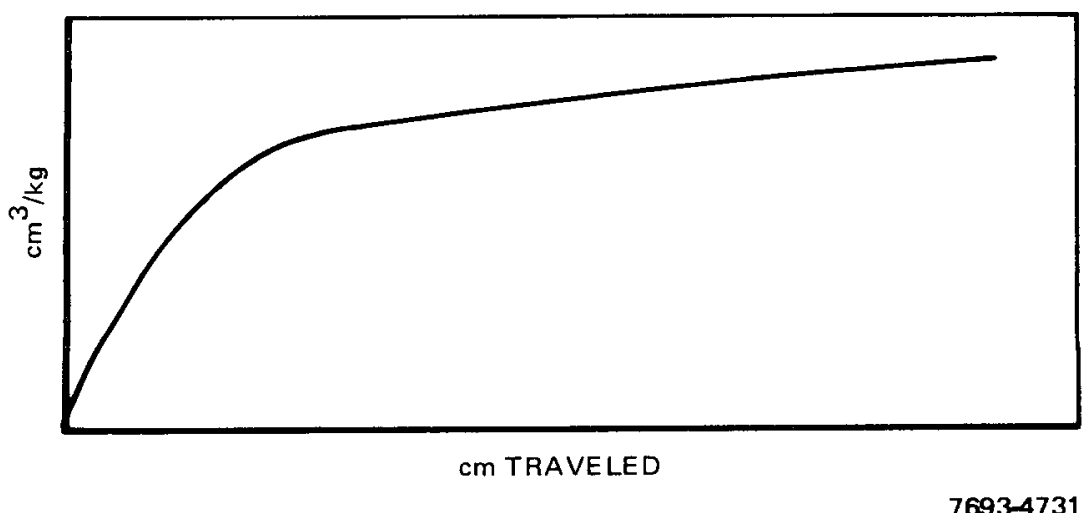

Figure 4. Volume Lost per Unit Load as a Function of Distance Traveled

Again, the $\mathrm{K}$ represents the slope of a line between the origin and the (volume lost/load, distance) point of an appropriate test. Use of the measured $\mathrm{K}$ value for shorter distances of rubbing would probably indicate too low an amount of wear. If very long distances are associated with very long times, the volume lost may well increase after distances associated with tens of thousands of hours at high temperatures. The $\mathrm{K}$ values from LMEC tests should be associated only with applications involving approximately the same distance or greater, but for times less than $500 \mathrm{hr}$ in the sodium at test temperature.

\section{Velocity Considerations}

The relationship between the wear rate coefficient and the velocity of rubbing cannot be estimated from first principles. If the velocity is high enough, hydrodynamic lift may begin to change the load. The formation of intermetallic junctions and polyoxide coatings is a time-dependent process and hence a function

\section{LMEC- $70-10$}


among others of velocity. Since increasing the velocity increases the surface temperature of the rubbing surfaces in the same manner as does increasing the load, an initial maximum followed by a minimum in the (volume lost/distance)versus-velocity curve might be expected. The increased velocity may cause additional generation of particulate matter and thereby increase the wear rate. The various factors interact in such a complicated way that no generality on the (volume lost/distance)-versus-rubbing velocity curve can be made at this time.

\section{COEFFICIENT OF SLIDING FRICTION}

One of the most important considerations for the designer is how the coefficient of sliding friction may build up to extremely high values during rubbing contact in sodium. In general, the wear rate is fairly low in sodium compared to other "lubricants, "but the increase in the coefficient of sliding friction in sodium is the parameter quite likely to be the most critical in a design. Ranges for this parameter are given in Tables 2 and 3.

\section{MISCELIANEOUS FACTORS}

Such factors as material availability, degradation after long times in sodium, brittle behavior, etc., are not indicated in Tables 2 and 3 but may be the critical factors in choosing the materials for sliding contact applications.

\section{E. DESIGN VALUES FROM SCREENING TEST DATA}

In the previous pages, the designer has been briefed as to the limitations of using the screening tests as a source of design information. In this section, the information of most interest to the designer has been abstracted from the total test data and presented in an easy-to-use form. This abstracted data is presented in two tables; one for a liquid sodium environment (Table 2) and the second for a sodium vapor environment (Table 3). The data points designated as typical are from the pins that exhibited the median value of wear while being tested at $\sim 125$-psi contact pressure.

The steps for using these tables are as follows:

1) Select from the appropriate tables a material combination for the sliding contact application based upon all the required material characteristics described in the previous pages. 
2) Check to see that the coefficient of sliding friction does not reach values that would adversely affect projected hardware operation.

3) Design the rubbing surface so that the contact pressure approximates 125 psi, the contact pressure range of the recorded data, and the geometry approximates a "pin" rubbing against a "plate." In the design application, the entire pin surface will be in contact throughout the sliding traverse, while material in the plate surface wear path will experience intermittent sliding contact. The data in the tables will not apply if the materials designated as pin and plate are interchanged.

4) Look up the typical value of $K$ (the black dot) in Table 2 or 3 that corresponds to the pin material running against the plate material. This value is the wear coefficient, $K$, for the pin material at that one temperature.

5) Calculate the total sliding distance, s, that the pin must rub.

6) Solve the equation $K=(h / s) / P$ for the depth of wear, $h$ :

$$
h=(K)(P)(s)
$$

If, for example, $K=0.8 \times 10^{-11}$ (in./in.)/psi and the pin pressure was 125 psi exactly, while the required rubbing distance was $10^{8}$ in., then the "pin" wear would be $h=\left(0.8 \times 10^{-11}\right)(125)\left(10^{8}\right)=0.1 \mathrm{in}$.

The general trend of these tentative design data can be inferred by the matrixes shown in Tables 4 and 5 .

\footnotetext{
*While this contact pressure may not necessarily be the optimum value, it is designated in this procedure to avoid high wear regimes which may occur at low or very high pressures (see Figure 2).
} 


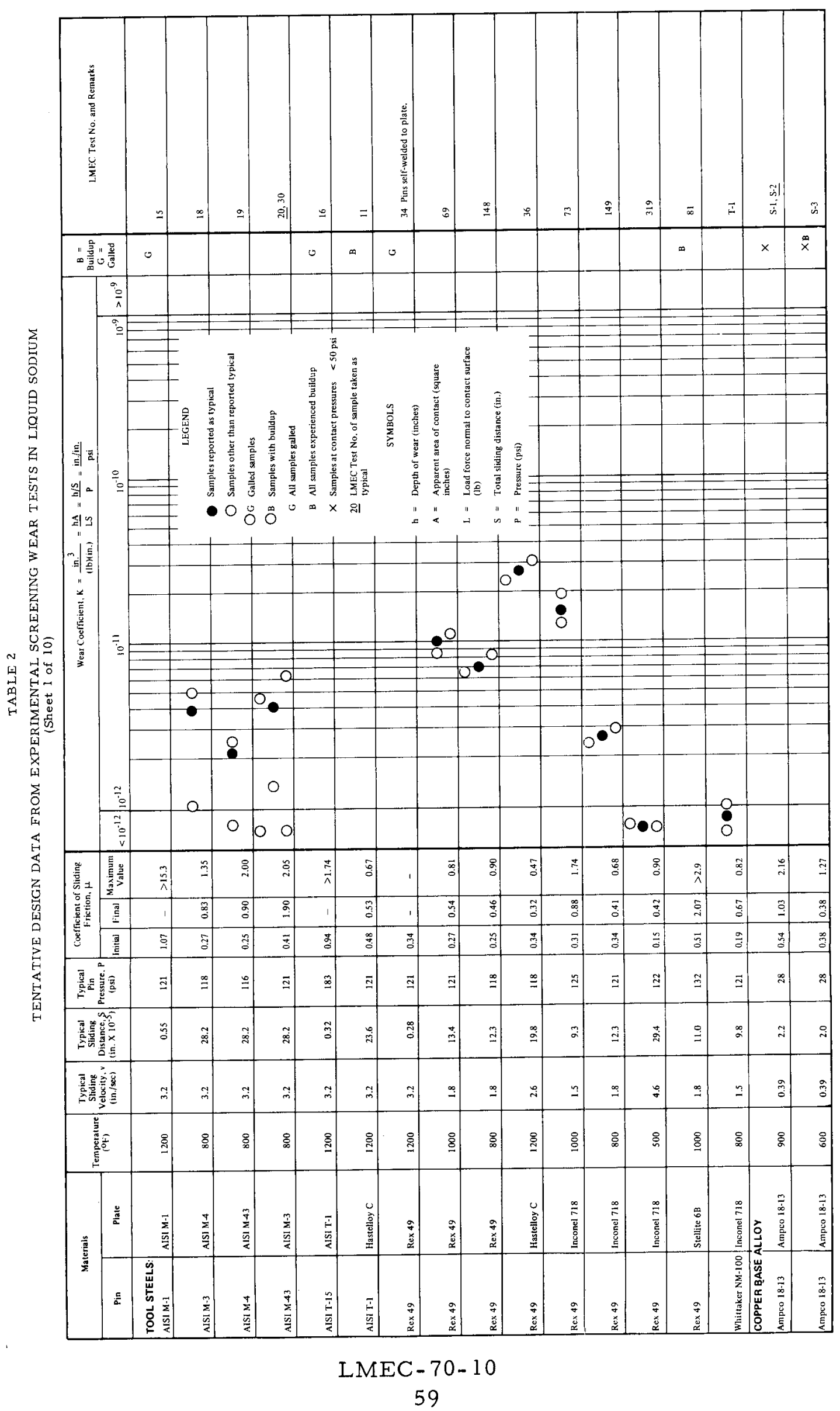


TABLE 2

TENTATIVE DESIGN DATA FROM EXPERIMENTAL SCREENING W EAR TESTS IN LIQUID SODIUM

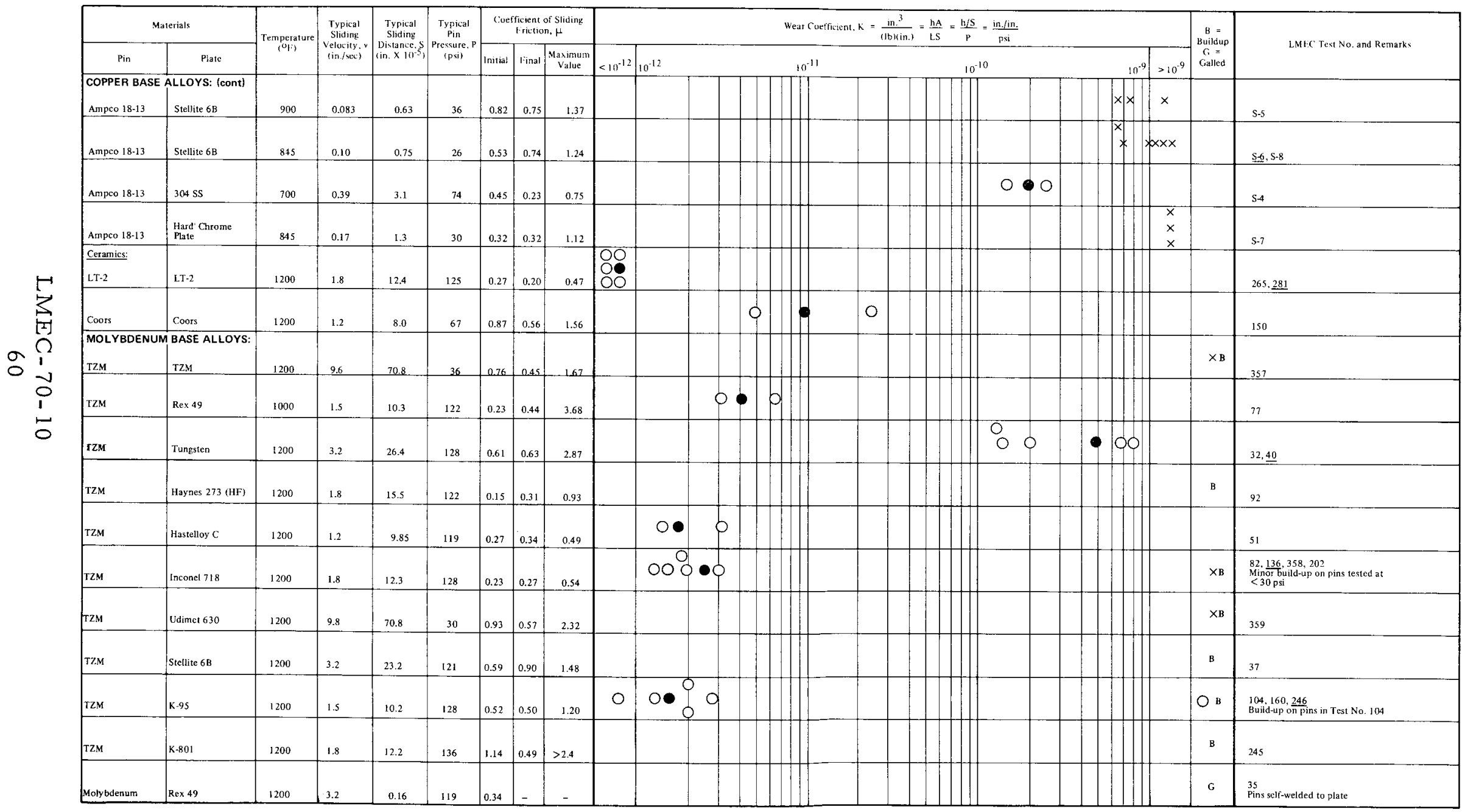


TABLE 2

TENT ATIVE DESIGN DATA FROM EXPERIMENTAI SCREENING WEAR TESTS IN LIQUID SODIUM

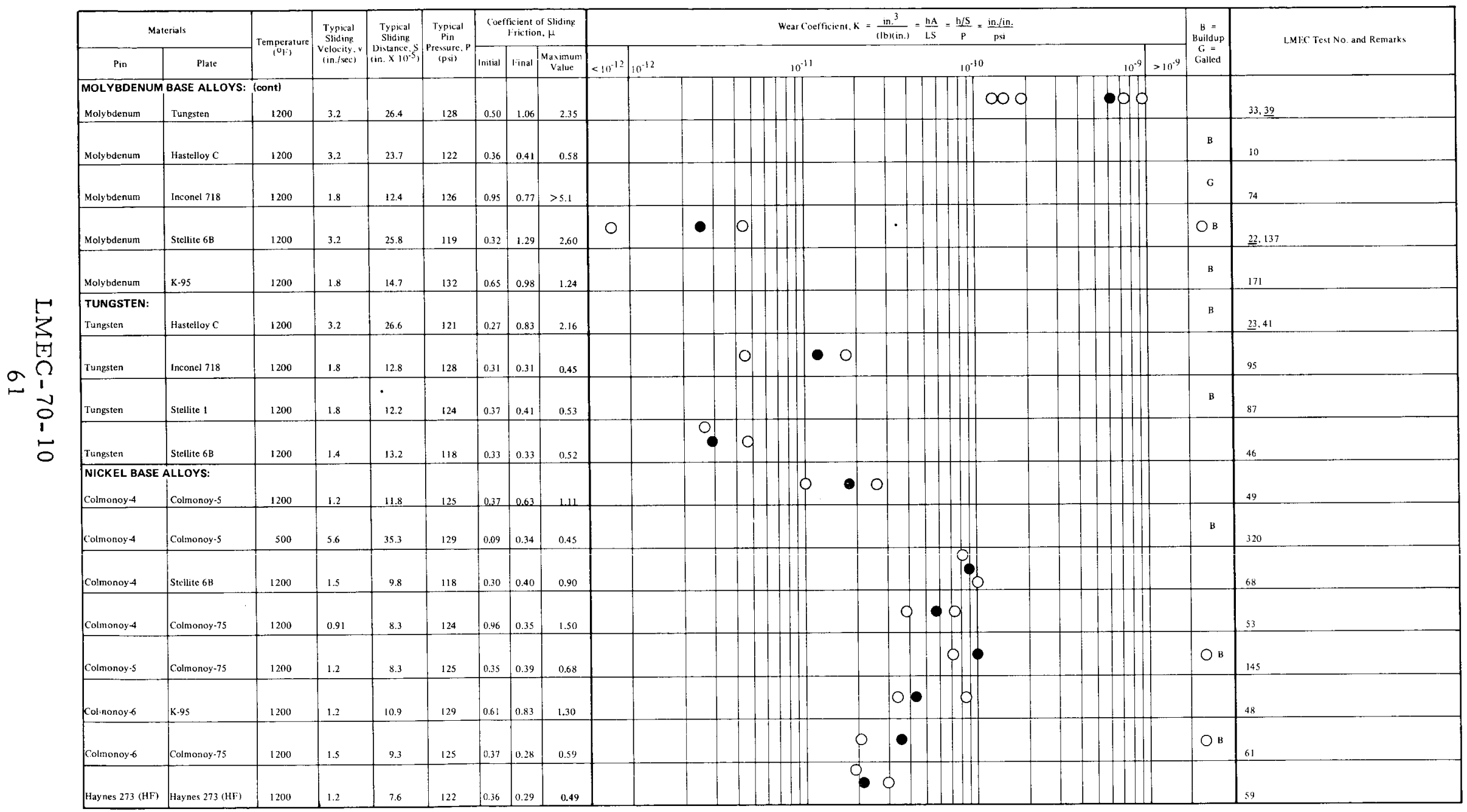


TABLE 2

TENTATTVE DESIGN DATA FROM EXPERIMENTAL SCREENING WEAR TESTS IN LIQUID SODIUM
(Sheet 4 of 10 )

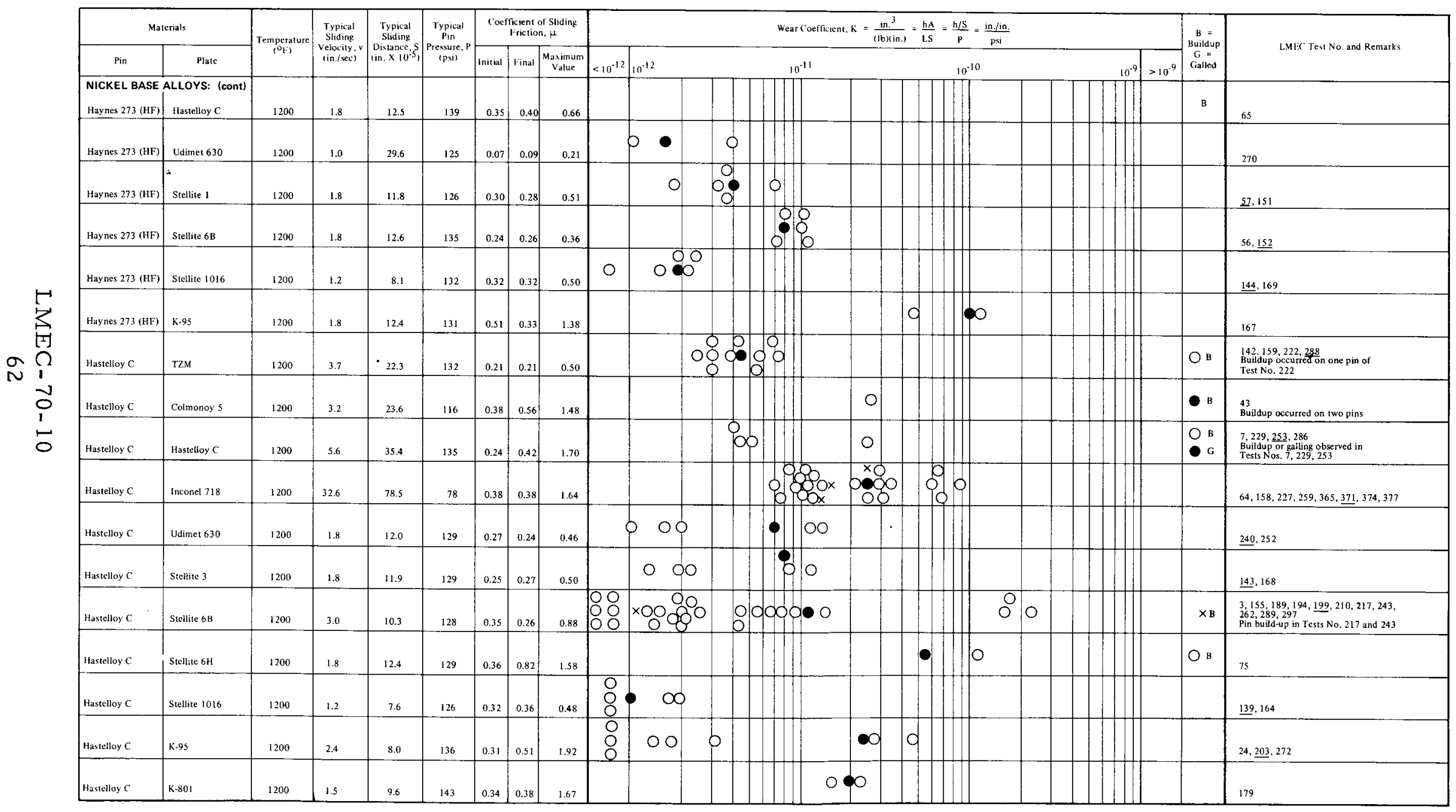


TABLE 2

TEN'T ATIVE DESIGN DATA FROM EXPERIMENTAL SCREENING WEAR TESTS IN LIQUID SODIUM (Sheet 5 of 10)

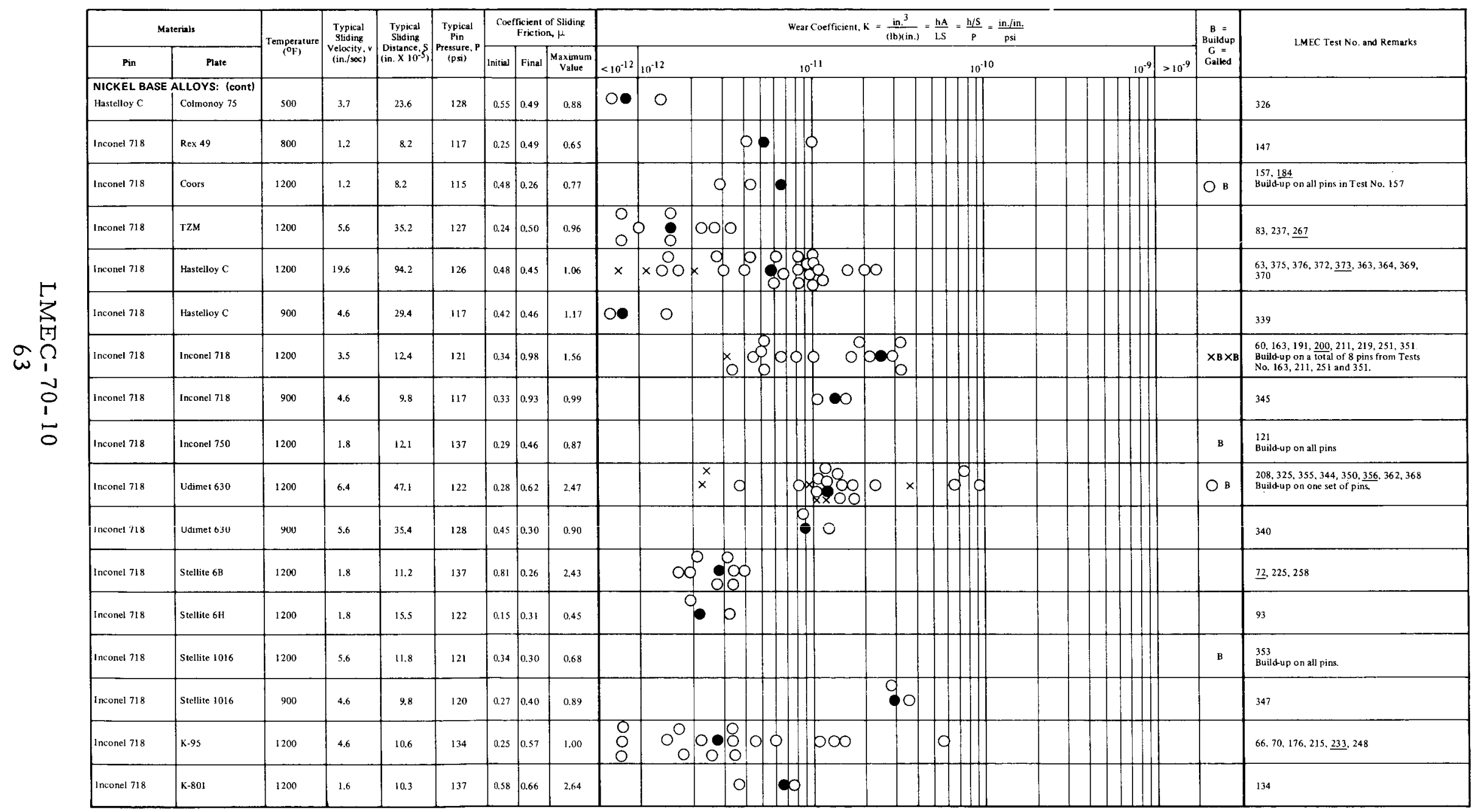


TABLE 2

TENTATIVE DESIGN DATA FROM EXPERIMENTAL SCREENING WEAR TESTS IN LIQUID SODIUM

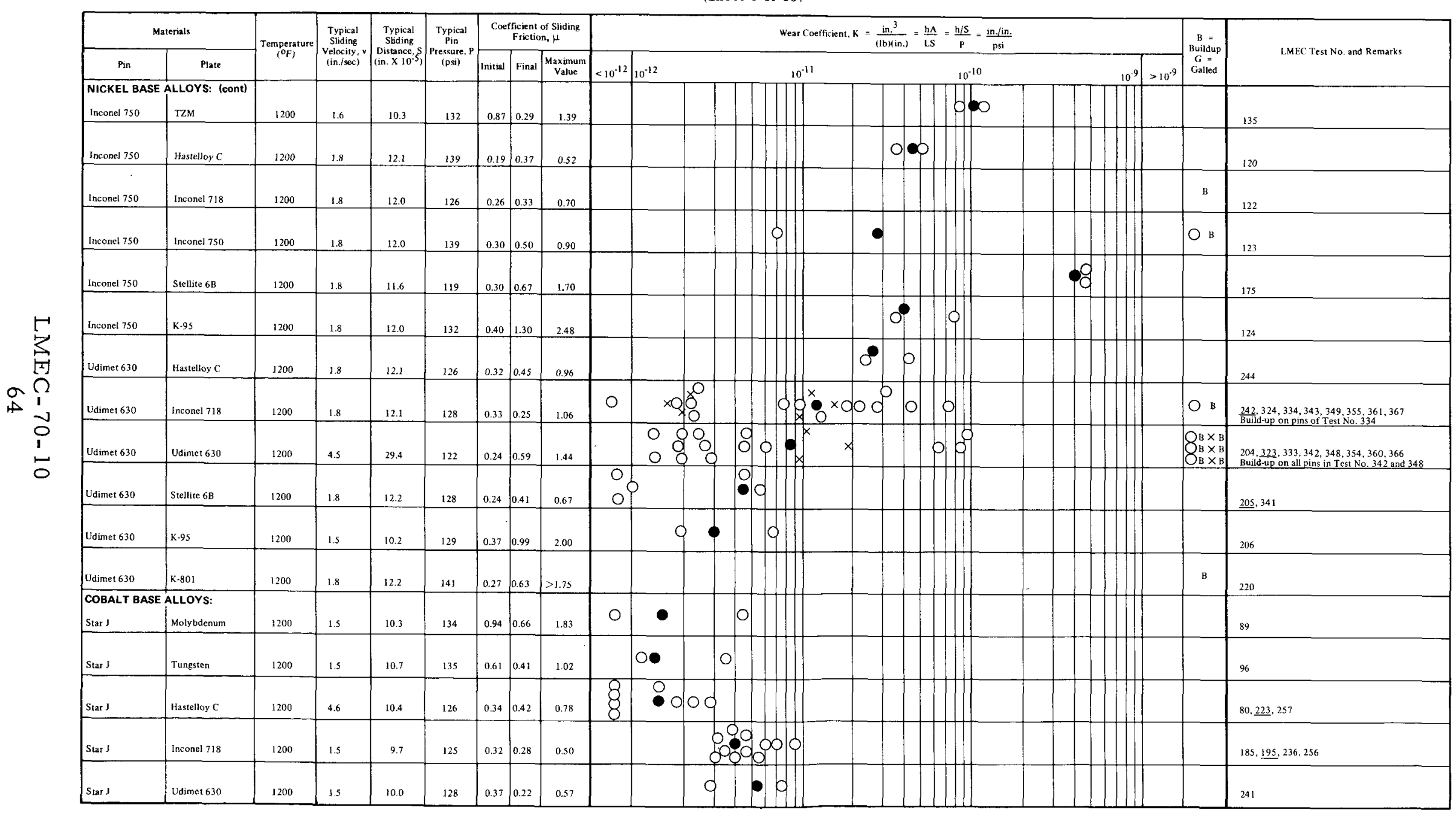


TABLE 2

TENTATIVE DESIGN DATA FROM EXPERIMENTAI SCREENING WEAR TESTS IN LIQUID SODIUM
(Sheet 7 of 10 )

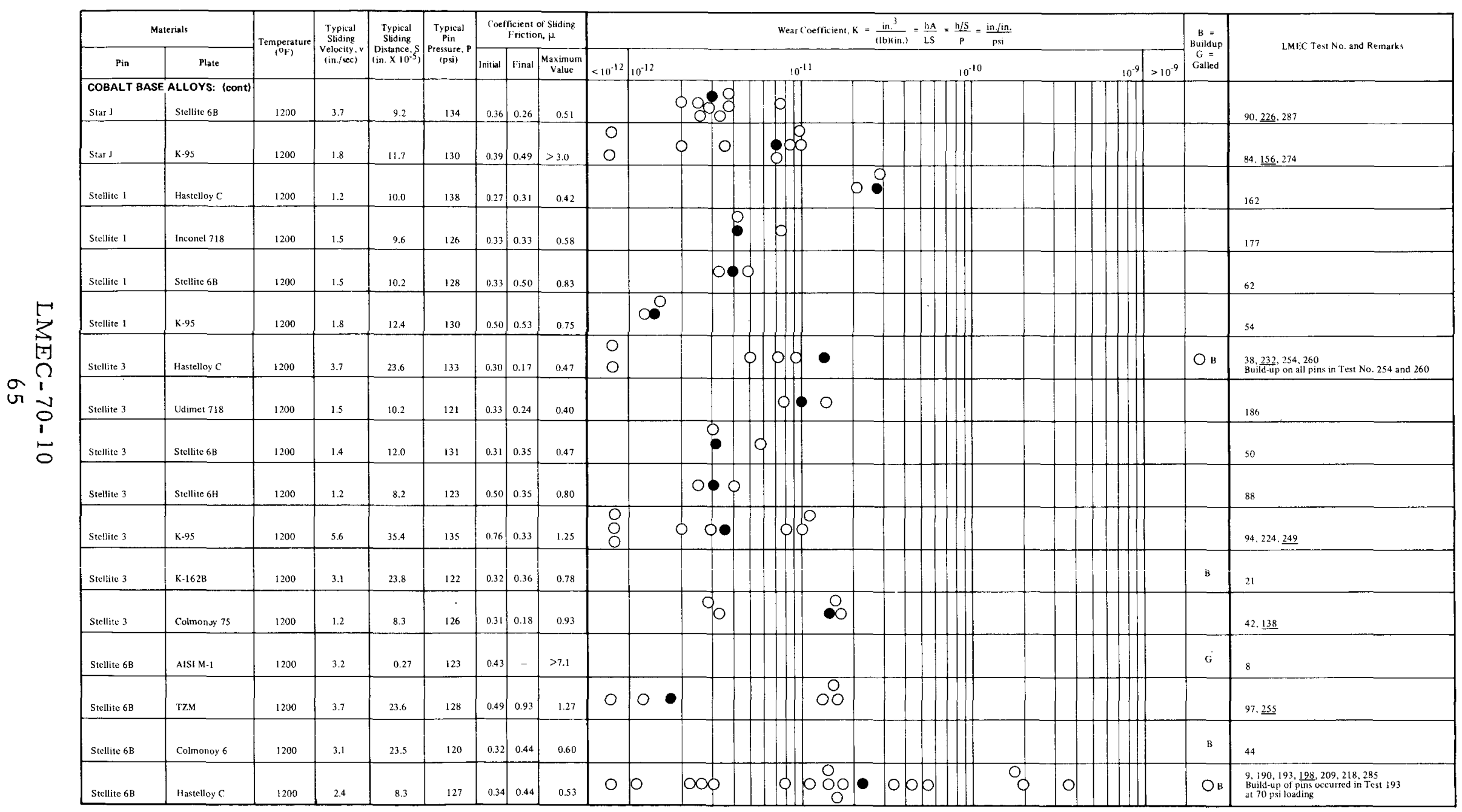


TABLE 2

TENTATIVE DESIGN DATA FROM EXPERIMENTAL SCREENING WEAR TESTS IN LIQUID SODIUM
(Sheet 8 of 10 )

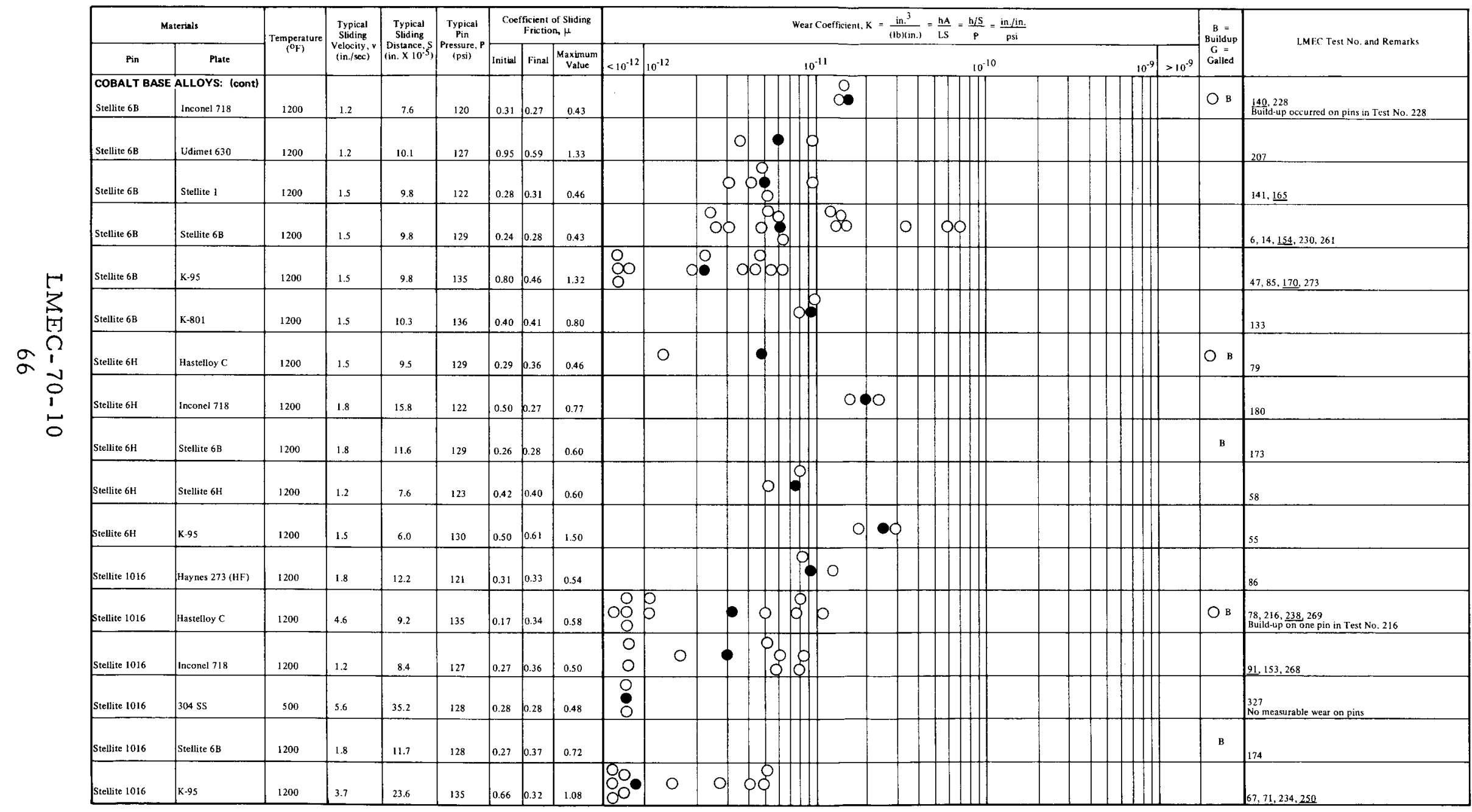


TABLE 2

IENTATIVE DESIGN DATA FROM EXPERLMENTAL SCREENING WEAR TESTS IN LIQUID SODIUM (Sheet 9 of 10

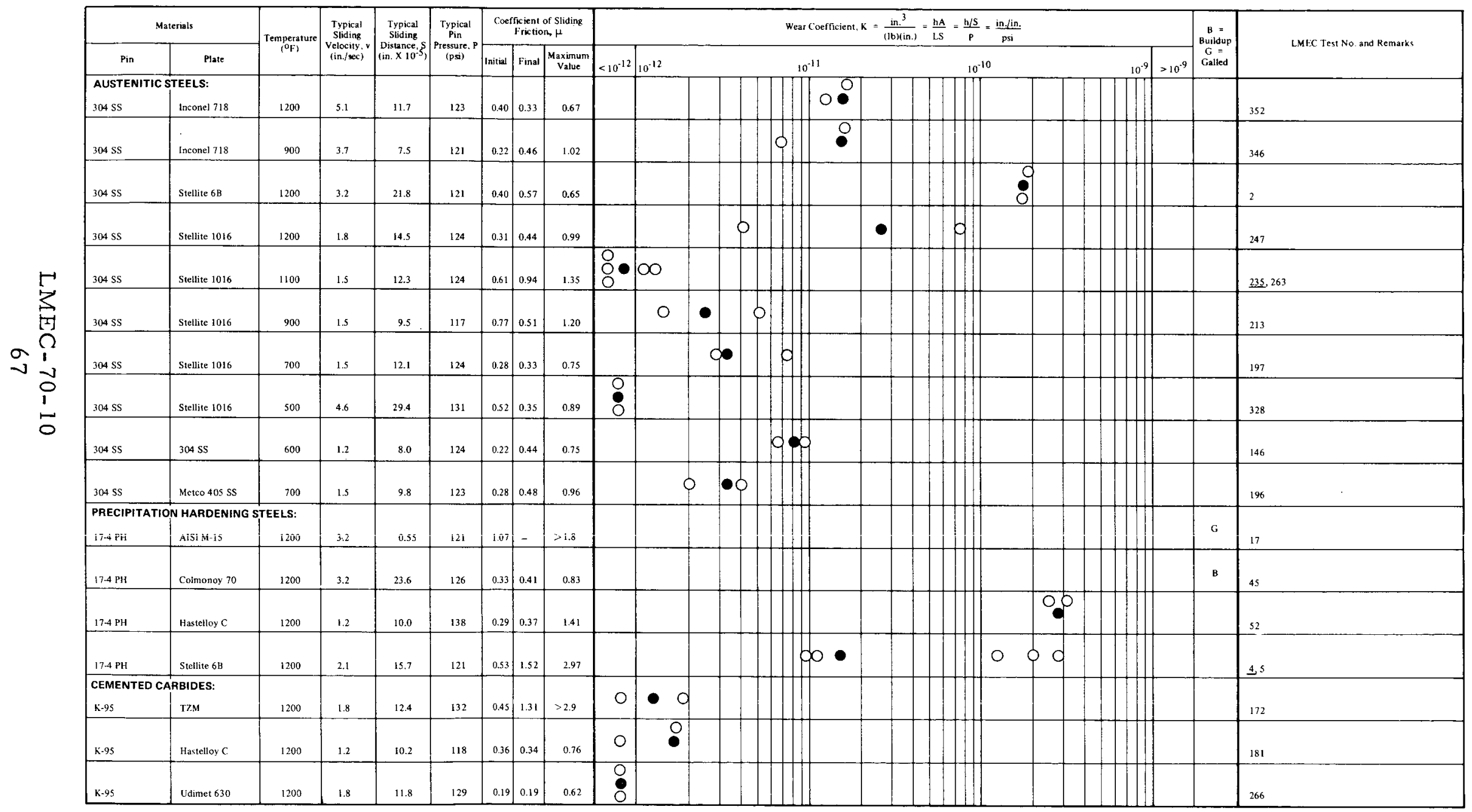


TABLE 2

TENTATIVE DESIGN DATA FROM EXPERIMENTAL SCREENING WEAR TESTS IN LIQUID SODIUM

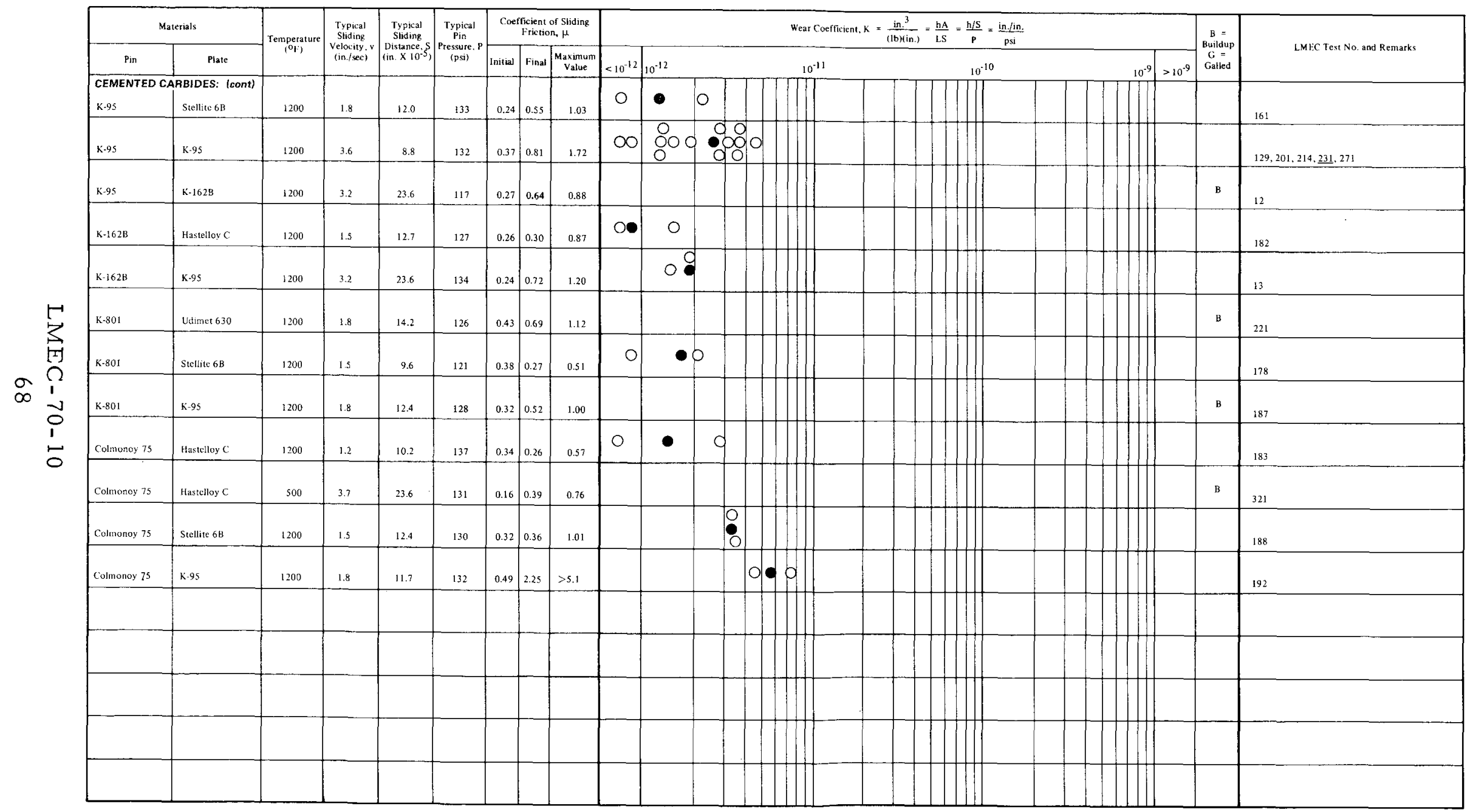


TABLE 3

TENTATIVE DESIGN DATA FROM EXPERIMENTAL SCREENING WEAR TESTS IN SODIUM VAPOR et 1 of 4)

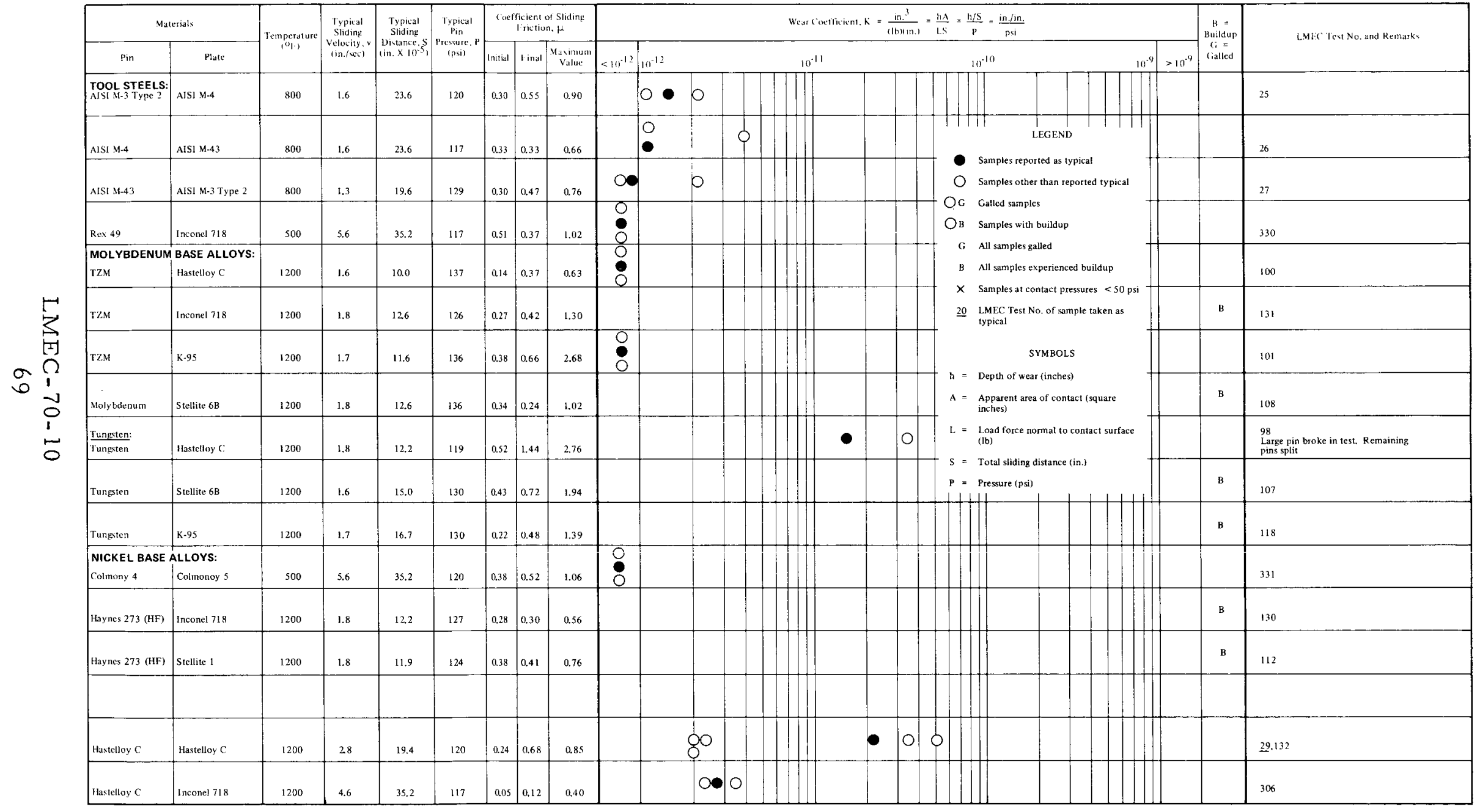


TABIE 3

TENTATIVE DESIGN DATA FROM EXPERIMENTAL SCREENING WEAR TESTS IN SODIUM VAPOR
(Sheet 2 of 4 )

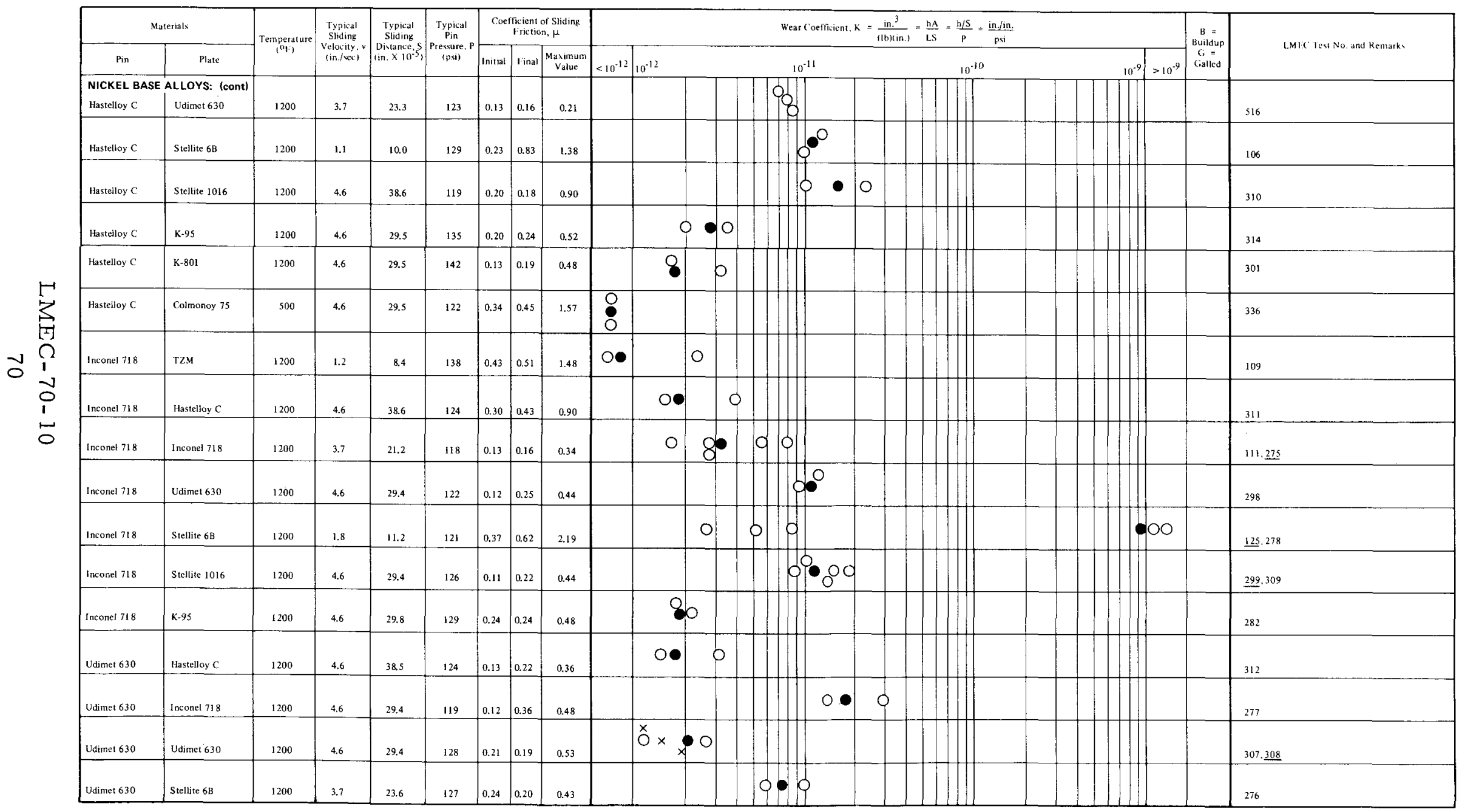

1 
TABLE 3

TENTATIVE DESIGN DATA FROM EXPERIMENTAL SCREENING WEAR TESTS IN SODIUM VAPOR

(Sheet 3 of 4 )

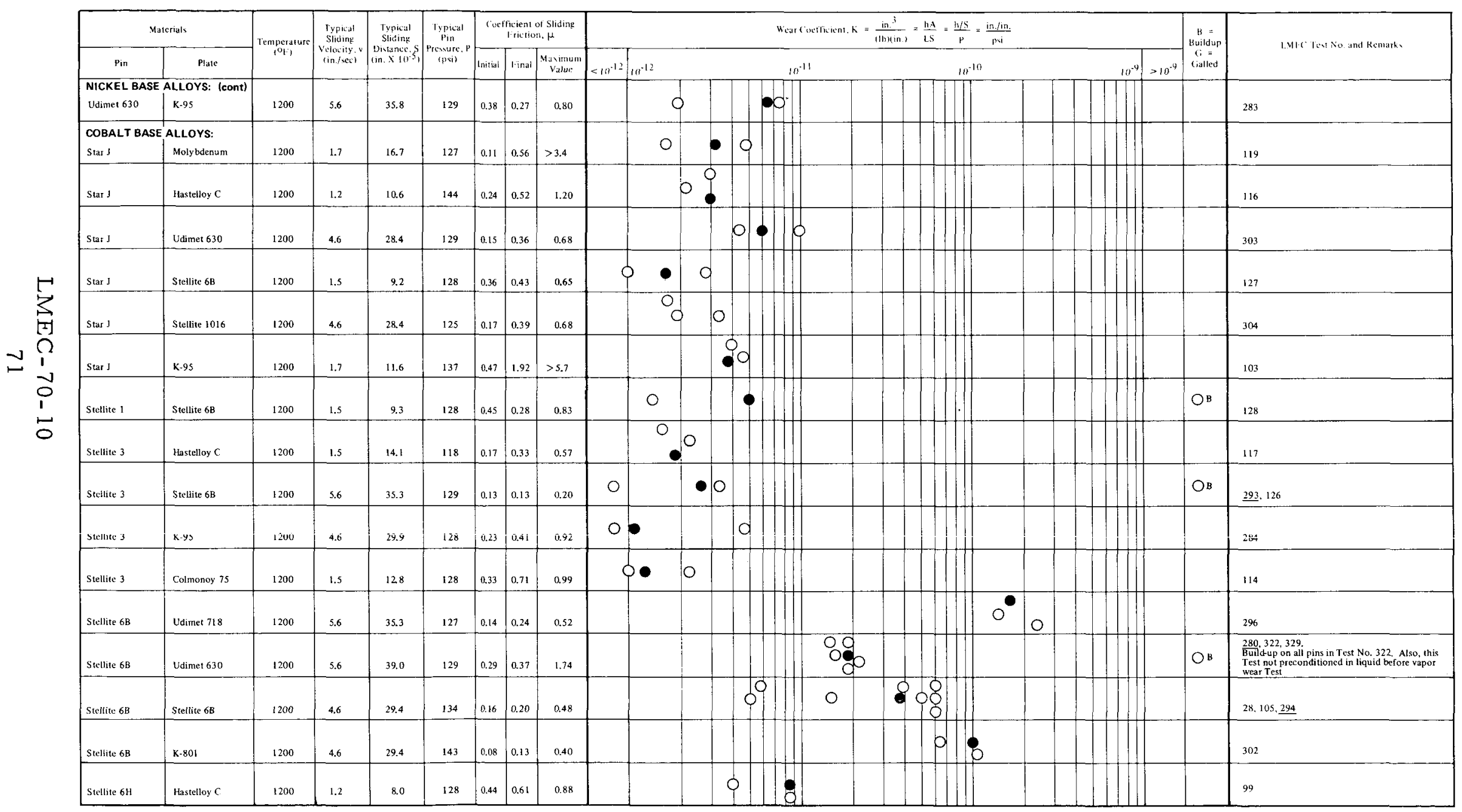


TABLE 4

TENTATIVE DESIGN DATA FROM EXPERIMENTAL SCREENING WEAR TESTS IN SODIUM VAPOR

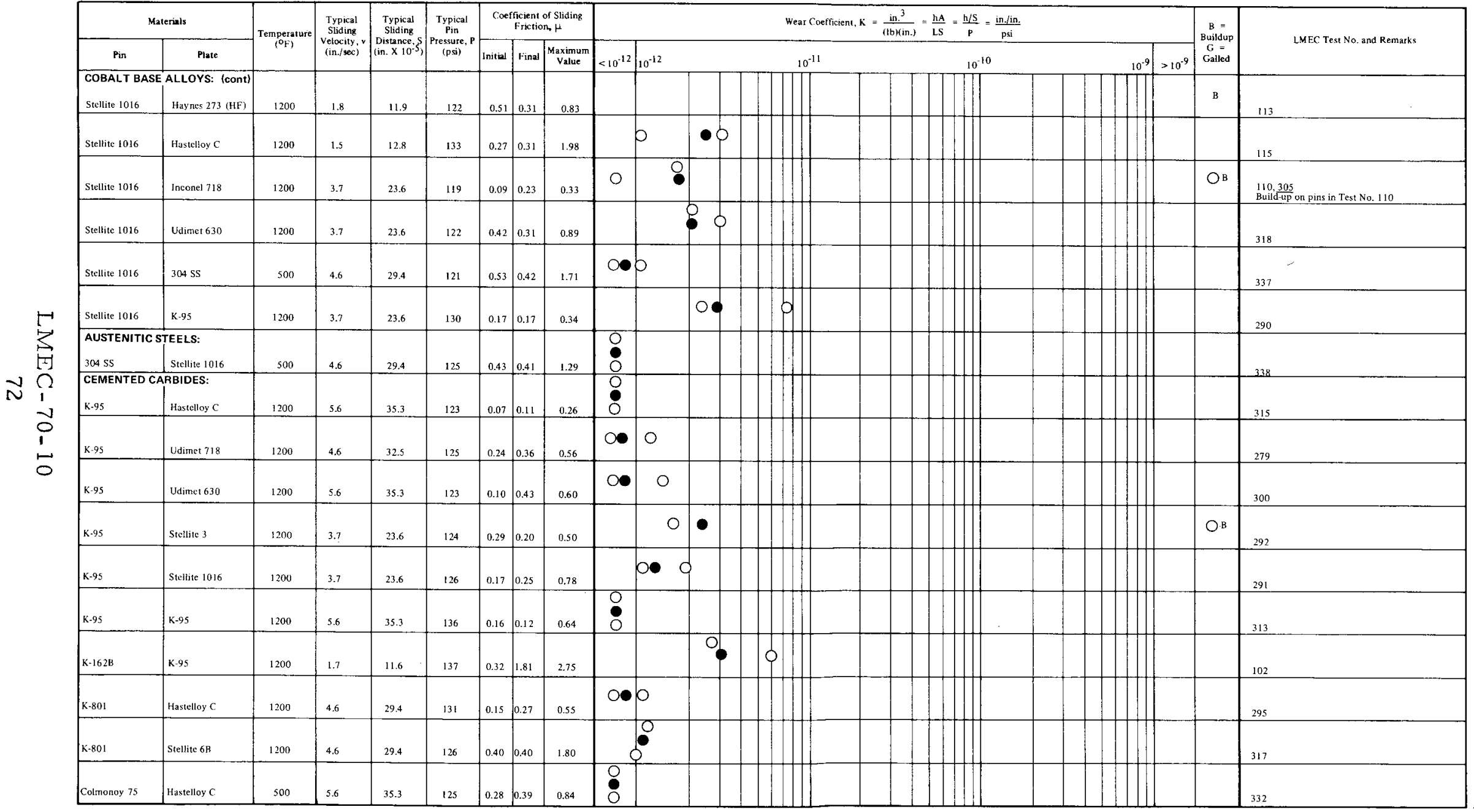

1 
TABIE 4

MATRIX - SLIDING WEAR IN LIQUID SODIUM AT $1200^{\circ} \mathrm{F}$

\begin{tabular}{|c|c|c|c|c|c|c|c|c|c|c|c|c|c|c|c|c|c|c|c|c|c|c|c|c|c|c|c|c|c|c|c|c|}
\hline \multirow{2}{*}{\multicolumn{2}{|c|}{ Pin Material }} & \multicolumn{31}{|c|}{ Plate Material } \\
\hline & & & 1 & 2 & 3 & 4 & 5 & 6 & 7 & 8 & 9 & 10 & 11 & 12 & 13 & 14 & 15 & 16 & 17 & 18 & 19 & 20 & 21 & 22 & 23 & 24 & 25 & 26 & 27 & 28 & 29 & 30 \\
\hline \multirow{4}{*}{ 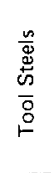 } & AISI-M-1 & 1 & G & & & & & & & & & & & & & & & & & & & & & & & & & & & & & \\
\hline & AISI-M-41 (Rex 49) & 2 & & $\mathrm{G}$ & & & w & & & & & & & & & & & & & & & & & & & & & & & & & \\
\hline & AISI-T-1 & 3 & & & & & B & & & & & & & & & & & & & & & & & & & & & & & & & \\
\hline & AISI-T.15 & 4 & & & G & & & & & & & & & & & & & & & & & & & & & & & & & & & \\
\hline \multirow{9}{*}{ 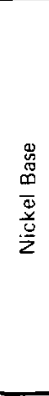 } & Hastelloy $\mathrm{C}$ & 5 & & & & & $\mathrm{G}$ & $w$ & & 2 & & $B$ & & & & & & 2 & $B$ & $B$ & 2 & $B$ & & & & & & & $w$ & & $w$ & \\
\hline & Inconel 718 & 6 & & & & & 2 & B & $B$ & B & & & & & & & & & 2 & 2 & B & 2 & & & & B & & & 2 & & 2 & \\
\hline & Inconel 750 & 7 & & & & & W & $\mathrm{B}$ & $\mathrm{B}$ & & & & & & & & & & $w$ & & & $w$ & & & & & & & w & & & \\
\hline & Udimet 630 & 8 & & & & & $w$ & $B$ & & B & & & & & & & & & 2 & & & & & & & & & & 2 & & $B$ & \\
\hline & Colmonoy 4 & 9 & & & & & & & & & & w & & & & & & & $w$ & & & & & & & & & & & & & $w$ \\
\hline & Colmonoy 5 & 10 & & & & & & & & & & & & & & & & & & & & & & & & & & & & & & $B$ \\
\hline & Colmonoy 6 & 11 & & & & & & & & & & & & & & & & & & & & & & & & & & & $w$ & & & $B$ \\
\hline & Colmonoy 70 & 12 & & & & & & & & & & & & & & & & & & & & & & & & & & & & & & \\
\hline & Haynes 273 & 13 & & & & & $B$ & & & 2 & & & & & w & & 2 & & 2 & & 2 & & & & & & & & $w$ & & & \\
\hline \multirow{6}{*}{ 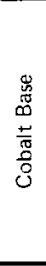 } & Star J & 14 & & & & & 2 & 2 & & 2 & & & & & & & & & 2 & & & & 2 & 2 & & & & & 2 & & & \\
\hline & Stellite 1 & 15 & & & & & $w$ & 2 & & & & & & & & & & & 2 & & & & & & & & & & 2 & & & \\
\hline & Stellite 3 & 16 & & & & & $B$ & $w$ & & & & & & & & & & & 2 & 2 & & & & & & & & & 2 & $B$ & & $w$ \\
\hline & Stellite $6 B$ & 17 & $\mathrm{G}$ & & & & B & B & & 2 & & & $B$ & & & & 2 & & 2 & & & 2 & & & & & & & 2 & & 2 & \\
\hline & Stellite $6 \mathrm{H}$ & 18 & & & & & B & $w$ & & & & & & & & & & & $B$ & 2 & & & & & & & & & $w$ & & & \\
\hline & Stellite 1016 & 19 & & & & & $B$ & 2 & & & & & & & w & & & & B & & & & & & & & & & 2 & & & \\
\hline \multirow{2}{*}{$\stackrel{0}{\Sigma}$} & TZM & 20 & & & & & 2 & B & & B & & & & & B & & & & B & & & B & & $w$ & & & & & B & & B & \\
\hline & Molybdenum & 21 & & G & & & B & G & & & & & & & & & & & B & & & & & $w$ & & & & & $B$ & & & \\
\hline 3 & Tungsten & 22 & & & & & B & $w$ & & & & & & & & & $\mathrm{~B}$ & & 2 & & & & & & & & & & 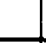 & & & \\
\hline \multirow{2}{*}{ 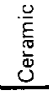 } & $\overline{L T .2}$ & 23 & & & . & & & & & & & & & & & & & & & & & & & & 1 & & & & & & & \\
\hline & Coors & 24 & & & & & & & & & & & & & & & & & & & & & & & & W & & & & & & \\
\hline \multirow{2}{*}{$\mathscr{H}$} & 304 & 25 & & & & & & $w$ & & & & & & & & & & & $w$ & & $w$ & & & & & & & & & & & \\
\hline & 17-4 PH & 26 & & & & & w & & & & & & & $B$ & & & & & $w$ & & & & & & & & & & & & & \\
\hline \multirow{4}{*}{$\begin{array}{l}\frac{0}{0} \\
\frac{0}{0} \\
\frac{0}{0} \\
0\end{array}$} & K.95 & 27 & & & & & 2 & & & 1 & & & & & & & & & 2 & & & 2 & & & & & & & 2 & $B$ & & \\
\hline & K-162B & 28 & & & & & 2 & & & & & & & & & & & & & & & & & & & & & & 2 & & & \\
\hline & K-801 & 29 & & & & & & & & B & & & & & & & & & 2 & & & & & & & & & & $B$ & & & \\
\hline & Colmonoy 75 & 30 & & & & & 2 & & & & & & & & & & & & 2 & & & & & & & & & & 2 & & & \\
\hline
\end{tabular}

Code

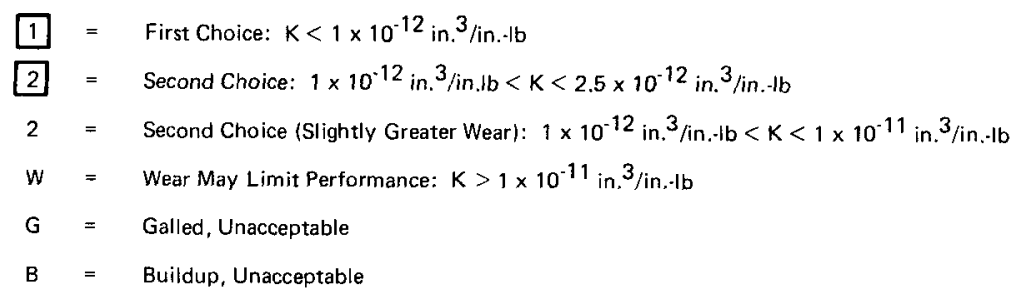


TABLE 5

MATRIX - SLIDING WEAR IN SODIUM VAPOR AT $1200^{\circ} \mathrm{F}$

\begin{tabular}{|c|c|c|c|c|c|c|c|c|c|c|c|c|c|c|c|c|c|c|c|}
\hline & \multirow{2}{*}{ Pin Material } & \multicolumn{18}{|c|}{ Plate Material } \\
\hline & & & 1 & 2 & 3 & 4 & 5 & 6 & 7 & 8 & 9 & 10 & 11 & 12 & 13 & 14 & 15 & 16 & 17 \\
\hline \multirow{4}{*}{$\begin{array}{l}\mathscr{D} \\
\tilde{D} \\
\infty \\
\bar{Z}\end{array}$} & Hastelloy C & 1 & W & 2 & 2 & & & & & W & & W & & & & & 2 & & 2 \\
\hline & Inconel 718 & 2 & 2 & 2 & W & & & & & W & & $w$ & 2 & & & & 2 & & \\
\hline & Udimet 630 & 3 & 2 & W & 2 & & & & & 2 & & & & & & & 2 & & \\
\hline & Haynes 273 & 4 & & B & & & & B & & & & & & & & & & & \\
\hline \multirow{6}{*}{ 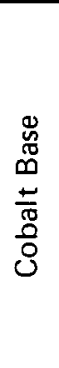 } & Star J & 5 & 2 & & 2 & & & & & 2 & & 2 & & 2 & & & 2 & & \\
\hline & Stellite 1 & 6 & & & & & & & & B & & & & & & & & & \\
\hline & Stellite 3 & 7 & 2 & & & & & & & B & & & & & & 2 & 2 & & \\
\hline & Stellite $6 B$ & 8 & & W & B & & & & & W & & & & & & & & & W \\
\hline & Stellite $6 \mathrm{H}$ & 9 & 2 & & & & & & & & & & & & & & & & \\
\hline & Stellite 1016 & 10 & 2 & B & 2 & $B$ & & & & & & & & & & & 2 & & \\
\hline \multirow{2}{*}{$\stackrel{\circ}{\Sigma}$} & $\mathrm{TZM}$ & 11 & 1 & B & & & & & & & & & & & & & 1 & & \\
\hline & Molybdenum & 12 & & & & & & & & B & & & & & & & & & \\
\hline 3 & Tungsten & 13 & W & & & & & & & B & & & & & & & $\mathrm{B}$ & & \\
\hline \multirow{4}{*}{$\frac{\mathscr{0}}{\frac{0}{0}}$} & Colmonoy 75 & 14 & & & & & & & & & & & & & & & & & \\
\hline & K-95 & 15 & 1 & 2 & 2 & & & & B & & & 2 & & & & & 1 & & \\
\hline & $K-162 B$ & 16 & & & & & & & & & & & & & & & 2 & & \\
\hline & K-801 & 17 & 2 & & & & & & & & & & & & & & & & \\
\hline
\end{tabular}

Code

$1=$ First Choice: $K<1 \times 10^{-12}$ in. $^{3} / \mathrm{in} .-1 \mathrm{~b}$

$2=$ Second Choice: $1 \times 10^{-12}$ in. $^{3} / \mathrm{in.} . \mathrm{lb}<\mathrm{K}<2.5 \times 10^{-12} \mathrm{in}^{3} / \mathrm{in} . \mathrm{lb}$

$2=$ Second Choice (Slightly Greater Wear): $1 \times 10^{-12} \mathrm{in}^{3} / \mathrm{in} .-\mathrm{lb}<K<1 \times 10^{-11} \mathrm{in}^{3} / \mathrm{in} . \mathrm{lb}$

$\mathrm{W}=$ Wear May Limit Performance: $K>1 \times 10^{-11} \mathrm{in} .^{3} / \mathrm{in} .-\mathrm{lb}$

$\mathrm{G}=$ Galled, Unacceptable

$\mathrm{B}=$ Buildup, Unacceptable

LMEC - 70 - 10 
PART 2

EXPERIMENTAL MATERIAL SCREENING AND ANALYTICAL STUDIES 


\section{TEST MATERIAL SELECTION}

Candidate materials were investigated, each in one or more tests, during the static and sliding contact investigations described in this report. These materials were selected for contact tests in liquid and vapor sodium at elevated temperatures to $650^{\circ} \mathrm{C}$ because of material compatibility with proposed environments, experimental results in sodium at various laboratories, past usage in sodium installations, availability, and anticipated desirable mechanical and chemical properties under Fast Flux Test Facility (FFTF) and Liquid Metal Fast Breeder Reactor ( $L M F B R$ ) conditions. Although a number of other materials have been developed which offer promising possibilities in sodium, most possess factors of similarity to one or more of the candidates selected. Thus, materials chosen tended to blanket the various types of acceptable superalloys and other materials for these tests which were of a screening nature.

Approximate chemical compositions of the candidate materials are given in Table 6. The heat treatments of the materials used are given in Table 7. 
TABLE 6

CHEMICAL ANALYSIS OF TEST MATERIALS

\begin{tabular}{|c|c|c|c|c|c|c|c|c|c|c|c|c|c|}
\hline Materials & $\mathrm{Ni}$ & $\mathrm{Co}$ & $\mathrm{Cr}$ & Mo & $w$ & $\mathrm{Fe}$ & C & $\mathrm{Ti}$ & Al & $\mathrm{Mn}$ & $\checkmark$ & $\mathrm{Si}$ & Other \\
\hline AISIM1 & & & 4.0 & 8.5 & 1.5 & Ba! & 0.80 & & & 0.3 & 1.1 & 0.3 & \\
\hline AISI M2* & & & 4.1 & 5.0 & 6.3 & $\mathrm{Ba}$ & 0.85 & & & 0.3 & 1.8 & 0.3 & \\
\hline AIS M3 Type 1* & & & 4.0 & 6.0 & 6.1 & Bal & 1.02 & & & 0.3 & 2.4 & 0.3 & \\
\hline A|S| M3 Type 2 & & & 4.1 & 6.0 & 6.0 & Bat & 1.20 & & & 0.3 & 3.2 & 0.3 & \\
\hline AISI M4 & & & 4.5 & 4.5 & 5.5 & Bal & 1.33 & & & 0.3 & 4.0 & 0.3 & \\
\hline AISI M15 & & 5.0 & 4.0 & 8.5 & 6.5 & Bal & 1.50 & & & 0.3 & 5.0 & 0.3 & \\
\hline AlSI M43 & & 8.2 & 3.7 & 8.7 & 1.8 & Bal & 1.23 & & & 0.3 & 2.0 & 0.3 & \\
\hline AISI T1 & & & 4.1 & 0.7 & 18.0 & Bal & 0.77 & & & 0.3 & 1.1 & 0.3 & \\
\hline AISI T15 & & 5.0 & 4.7 & 0.5 & 12.5 & Bal & 1.57 & & & 0.3 & 5.0 & 0.3 & \\
\hline Ampco 18.13 & & & & & & 3.5 & & & 11.0 & & & & $85.5 \mathrm{Cu}$ \\
\hline Colmonoy 4 & Bal & & 10.0 & & & 2.5 & 0.45 & & & & & 2.2 & $2.0 \mathrm{~B}$ \\
\hline Colmonoy $5(\mathrm{HF}) \dagger$ & Bal & & 11.5 & & & 4.2 & 0.65 & & & & & 3.7 & $2.5 \mathrm{~B}$ \\
\hline Colmonoy 6 (HF) & Bal & & 13.5 & & & 4.7 & 0.75 & & & & & 4.2 & $3.0 \mathrm{~B}$ \\
\hline Colmonoy $70(\mathrm{HF})$ & Bal & & 11.5 & & 16.0 & 3.7 & 0.55 & & & & & 3.2 & $2.5 \mathrm{~B}$ \\
\hline Colmonoy 75 (HF) & & & Same as & onov $6 \mathrm{pl}$ & is WC particl & & & & & & & & \\
\hline Coors AD 995 & & & & & & & & & & & & & $\sim 100 \mathrm{Al}_{2} \mathrm{O}_{3}$ \\
\hline Hastelloy C & Bal & 2.5 & 15.6 & 16.0 & 4.0 & 5.0 & $0.08 \varsigma$ & & & & & & \\
\hline Haynes 273 (HF) & Bal & & 16.0 & 17.0 & 4.5 & 5.3 & 0.10 & & & & & & \\
\hline Inconel 718 & 53.0 & 0.1 & 18.5 & 3.0 & & Bal & 0.05 & 1.0 & 0.5 & & & 0.2 & $5.1 \mathrm{Nb}+\mathrm{Ta}$ \\
\hline Inconel 750 & 70.0 & & 15.5 & & & $\mathrm{Bal}$ & 0.08 & 2.5 & 0.7 & 1.0 & & 0.53 & $0.6 \mathrm{Nb}$ \\
\hline K-95 (WC! & & 9.0 & & & $91.0(\mathrm{WC})$ & & & & & & & & \\
\hline $\mathrm{K}-162 \mathrm{~B}(\mathrm{TiC})$ & 25.0 & & & 5.0 & & & & $63.0(\mathrm{TiC})$ & & & & & $5.3 \mathrm{Nb}+\mathrm{Ta}$ \\
\hline$K-801$ & 6.0 & & & & $94.0(\mathrm{WC})$ & & & & & & & & \\
\hline LT.2 & & & 25.0 & & 60.0 & & & & & & & & $15.0 \mathrm{Al}_{2} \mathrm{O}_{3}$ \\
\hline Molybdenum & & & & 99.9 & & & & & & & & & \\
\hline $\operatorname{Re} \times 49$ & & 5.0 & 4.2 & 3.7 & 6.7 & $\mathrm{Ba}$ & 1.10 & & & 0.4 & 2.0 & 0.3 & \\
\hline 17.4 PH SS & 4.0 & & 16.5 & & & Bal & 0.07 & & & $2.0 \leq$ & & $1.0 \S$ & $4.0 \mathrm{Cu}$ \\
\hline 304 SS & 9.5 & & 19.0 & & & $\mathrm{Bal}$ & 0.08 & & & $2.0 s$ & & $1.0 \xi$ & \\
\hline $316 \mathrm{SS}$ & 12.5 & & 17.0 & 2.5 & & $\mathrm{Bal}$ & 0.10 & & & & & 1.0 & \\
\hline Metco 405 SS & & & 13.0 & & & Bal & 0.08 & & 0.2 & 1.05 & & 1.05 & \\
\hline Stellite 1 (HF) & & Bal & 30.0 & & 12.0 & & 2.50 & & & & & & \\
\hline Stellite 3 & 3.0 & Bal & 30.5 & & 12.5 & 3.0 s & 2.45 & & & & & 1.0 & \\
\hline Stellite 6B & $3.0 \$$ & $\mathrm{Bal}$ & 30.0 & $1.5 \stackrel{5}{s}$ & 4.5 & $3.0 \mathrm{~s}$ & 1.10 & & & & & $2.0^{5}$ & \\
\hline Stellite $6 \mathrm{H}(\mathrm{HF})$ & & $\mathrm{Bal}$ & 28.0 & & 4.0 & & 1.10 & & & & & & \\
\hline Stellite $1016(\mathrm{HF})$ & & $\mathrm{Bal}$ & 32.0 & & 17.0 & & 2.50 & & & & & & \\
\hline Stellite Star J & $2.5 s$ & $\mathrm{Bal}$ & 32.0 & & 17.0 & $3.0 \mathrm{~s}$ & 2.50 & & & & & & \\
\hline $\begin{array}{l}\text { TZM } \\
\text { Tungsten }\end{array}$ & & & & 99.4 & 99.9 & & & 0.5 & & & & & $0.08 \mathrm{Zr}$ \\
\hline Udimet 630 & $\mathrm{Bal}$ & 1.05 & 17.0 & 3.0 & 3.0 & 17.5 & $0.04 i$ & 1.1 & 0.6 & & & $0.2 \leqslant$ & $6.4 \mathrm{Nb}+\mathrm{Ta}$ \\
\hline Whittaker NM 100 & & 9.5 & 17.5 & & 10.5 & 60.5 & 1.25 & & & & 0.7 & & \\
\hline
\end{tabular}

* Static Contact Tests Only

5 Maximum

$+H F=$ Hard Facing 
TABLE 7

HEAT TREATMENTS OF TEST MATERIALS

(Sheet 1 of 5)

\begin{tabular}{|c|c|c|c|}
\hline Material & Form & Hardness & Heat Treatment \\
\hline AISI MI & $\begin{array}{l}\text { Pins and } \\
\text { Plates }\end{array}$ & $R_{c} 47-53$ & $\begin{array}{l}\text { Preheat } 1 / 2 \mathrm{hr} \text { at } 1000^{\circ} \mathrm{F}+1 / 2 \mathrm{hr} \\
\text { at } 1500^{\circ} \mathrm{F}+\text { Austenitize } 2-5 \mathrm{~min} \\
\text { at } 2200^{\circ} \mathrm{F}+\text { salt quench to } 1000^{\circ} \mathrm{F} \\
+ \text { air cool to } 100^{\circ} \mathrm{F}+\text { double tem }- \\
\text { per per: } 2\left(2 \mathrm{hr} \text { at } 1200^{\circ} \mathrm{F}+\text { air }\right. \\
\text { cool })\end{array}$ \\
\hline AISI M3 Type 2 & $\begin{array}{l}\text { Pins and } \\
\text { Plates }\end{array}$ & $R_{c} 47-51$ & $\begin{array}{l}\text { Preheat } 1 / 2 \mathrm{hr} \text { at } 1000^{\circ} \mathrm{F}+1 / 2 \mathrm{hr} \\
\text { at } 1500^{\circ} \mathrm{F}+\text { Austenitize } 2-5 \mathrm{~min} \\
\text { at } 2200^{\circ} \mathrm{F}+\text { salt quench to } 1000^{\circ} \mathrm{F} \\
+ \text { air cool to } 100^{\circ} \mathrm{F}+\text { double tem }- \\
\text { per per: } 2\left(2 \mathrm{hr} \text { at } 1200^{\circ} \mathrm{F}+\text { air }\right. \\
\text { cool) }\end{array}$ \\
\hline AISI M4 & $\begin{array}{l}\text { Pins and } \\
\text { Plates }\end{array}$ & $R_{c} 47-51$ & $\begin{array}{l}\text { Preheat } 1 / 2 \mathrm{hr} \text { at } 1000^{\circ} \mathrm{F}+1 / 2 \mathrm{hr} \\
\text { at } 1500^{\circ} \mathrm{F}+\text { Austenitize } 2-5 \mathrm{~min} \\
\text { at } 2200^{\circ} \mathrm{F}+\text { salt quench to } 1000^{\circ} \mathrm{F} \\
+ \text { air cool to } 100^{\circ} \mathrm{F}+\text { double tem } \\
\text { per per: } 2\left(2 \mathrm{hr} \text { at } 1200^{\circ} \mathrm{F}+\text { air }\right. \\
\text { cool })\end{array}$ \\
\hline AISI M15 & Plate & $R_{c} 50-52$ & $\begin{array}{l}\text { Preheat } 1 / 2 \mathrm{hr} \text { at } 1000^{\circ} \mathrm{F}+1 / 2 \mathrm{hr} \\
\text { at } 1500^{\circ} \mathrm{F}+\text { Austenitize } 2-5 \mathrm{~min} \\
\text { at } 2200^{\circ} \mathrm{F}+\text { salt quench to } 1000^{\circ} \mathrm{F} \\
+ \text { air cool to } 100^{\circ} \mathrm{F}+\text { double tem- } \\
\text { per per: } 2\left(2 \mathrm{hr} \text { at } 1200^{\circ} \mathrm{F}+\text { air }\right. \\
\text { cool) }\end{array}$ \\
\hline AISI M43 & $\begin{array}{l}\text { Pins and } \\
\text { Plates }\end{array}$ & $R_{c} 48-53$ & $\begin{array}{l}\text { Preheat } 1 / 2 \mathrm{hr} \text { at } 1000^{\circ} \mathrm{F}+1 / 2 \mathrm{hr} \\
\text { at } 1500^{\circ} \mathrm{F}+\text { Austenitize } 2-5 \mathrm{~min} \\
\text { at } 2150^{\circ} \mathrm{F}+\text { salt quench to } 1000^{\circ} \mathrm{F} \\
+ \text { air cool to } 100^{\circ} \mathrm{F}+\text { double tem- } \\
\text { per per: } 2\left(2 \mathrm{hr} \text { at } 1200^{\circ} \mathrm{F}+\text { air }\right. \\
\text { cool) }\end{array}$ \\
\hline AISI T 1 & Plates & $R_{c} 51-55$ & $\begin{array}{l}\text { Preheat } 1 / 2 \mathrm{hr} \text { at } 1000^{\circ} \mathrm{F}+1 / 2 \mathrm{hr} \\
\text { at } 1500^{\circ} \mathrm{F}+\text { Austenitize } 2-5 \mathrm{~min} \\
\text { at } 2300^{\circ} \mathrm{F}+\text { salt quench to } 1000^{\circ} \mathrm{F} \\
+ \text { air cool to } 100^{\circ} \mathrm{F}+\text { double tem }- \\
\text { per per: } 2\left(2 \mathrm{hr} \text { at } 1200^{\circ} \mathrm{F}+\text { air }\right. \\
\text { cool })\end{array}$ \\
\hline
\end{tabular}

LMEC - 70-10 
TABLE 7

HEAT TREATMENTS OF TEST MATERIALS

(Sheet 2 of 5 )

\begin{tabular}{|c|c|c|c|}
\hline Material & Form & Hardness & Heat Treatment \\
\hline AISI T 15 & Pins & $R_{c} 50-52$ & $\begin{array}{l}\text { Preheat } 1 / 2 \mathrm{hr} \text { at } 1000^{\circ} \mathrm{F}+1 / 2 \mathrm{hr} \\
\text { at } 1500^{\circ} \mathrm{F}+\text { Austenitize } 2-5 \mathrm{~min} \\
\text { at } 2050^{\circ} \mathrm{F}+\text { salt quench } \text { to } 1000^{\circ} \mathrm{F} \\
+ \text { air cool to } 100^{\circ} \mathrm{F}+\text { double tem- } \\
\text { per per: } 2\left(2 \mathrm{hr} \text { at } 1200^{\circ} \mathrm{F}+\mathrm{air}\right. \\
\text { cool })\end{array}$ \\
\hline AMPCO $18-13$ & $\begin{array}{l}\text { Pins and } \\
\text { Plates }\end{array}$ & $\begin{array}{l}R_{c 1-60} 51-60 \\
R_{c}^{c_{4}} 4-53\end{array}$ & $\begin{array}{l}\text { Proprietary heat treatment - must } \\
\text { be done by AMPCO - to heat spec. } \\
-13\end{array}$ \\
\hline Colmonoy 4 & Pins & $R_{c} 37-38$ & $\begin{array}{l}\text { Plasma-sprayed hardfacing - not } \\
\text { heat treated }\end{array}$ \\
\hline Colmonoy 5 & $\begin{array}{l}\text { Pins and } \\
\text { Plate }\end{array}$ & $R_{C} 42-50$ & $\begin{array}{l}\text { Plasma-sprayed hardfacing - not } \\
\text { heat treated }\end{array}$ \\
\hline Colmonoy 6 & $\begin{array}{l}\text { Pins and } \\
\text { Plate }\end{array}$ & $R_{C} 55-56$ & $\begin{array}{l}\text { Plasma-sprayed hardfacing - not } \\
\text { heat treated }\end{array}$ \\
\hline Colmonoy 70 & Plates & $R_{C} 51-54$ & $\begin{array}{l}\text { Plasma-sprayed hardfacing - not } \\
\text { heat treated }\end{array}$ \\
\hline Colmonoy 75 & $\begin{array}{l}\text { Pins and } \\
\text { Plate }\end{array}$ & $R_{c} 58-63$ & $\begin{array}{l}\text { Plasma-sprayed hardfacing - not } \\
\text { heat treated }\end{array}$ \\
\hline Coors AD-995 & Plate & $R_{c} 59-60$ & Ceramic material - not heat treated \\
\hline Hard Chrome & Plate & $R_{c} 61-62$ & As plated - not heat treated \\
\hline Hastelloy C & $\begin{array}{l}\text { Pins and } \\
\text { Plate }\end{array}$ & $R_{B} 94-95$ & $\begin{array}{l}\text { Solution anneal } 1 \mathrm{hr} \text { at } 2225^{\circ} \mathrm{F}+ \\
\text { water quench (ASTM-B334-62) }\end{array}$ \\
\hline Haynes 273 & $\begin{array}{l}\text { Pins and } \\
\text { Plate }\end{array}$ & $R_{A} 56-62$ & $\begin{array}{l}\text { Oxy-acetylene-applied hardfacing - } \\
\text { not heat treated }\end{array}$ \\
\hline $\begin{array}{l}\text { Inconel } 718 \\
\text { (+ Udimet } \\
718)\end{array}$ & $\begin{array}{l}\text { Pins and } \\
\text { Plate }\end{array}$ & $R_{c} 37-43$ & $\begin{array}{l}\text { Solution treat } 2 \mathrm{hr} \text { at } 2200^{\circ} \mathrm{F} \text { (in } \\
\mathrm{H}_{2}, \text { vacuum, or inert atmosphere) } \\
+ \text { air or oil quench to below } 1000^{\circ} \mathrm{F} \\
+ \text { age in } \mathrm{H}_{2}, \text { vacuum, or inert } \\
\text { atmosphere per: } 1 \mathrm{hr} \text { at } 1450^{\circ} \mathrm{F} \\
+10 \mathrm{hr} \text { at } 1400^{\circ} \mathrm{F}+\operatorname{cool} \text { to } 1200^{\circ} \mathrm{F} \\
\text { at } 100^{\circ} / \mathrm{hr} \text { and hold at } 1200^{\circ} \mathrm{F} \text { for } \\
\text { total ageing time of } 20 \mathrm{hr}+\text { fur }- \\
\text { nace or retort cool }\end{array}$ \\
\hline
\end{tabular}

LMEC-70- 10 
TABLE 7

HEAT TREATMENTS OF TEST MATERIALS

(Sheet 3 of 5 )

\begin{tabular}{|c|c|c|c|}
\hline Material & Form & Hardness & Heat Treatment \\
\hline $\begin{array}{l}\text { Inconel } 750 \\
\text { (Inconel X } \\
\text { Inconel X-750) }\end{array}$ & $\begin{array}{l}\text { Pins and } \\
\text { Plate }\end{array}$ & $R_{c} 28-30$ & $\begin{array}{l}\text { Solution treat } 2 \mathrm{hr} \text { at } 2100^{\circ} \mathrm{F} \text { (in } \\
\mathrm{H}_{2} \text {, vacuum, or inert atmosphere) } \\
+ \text { air or oil quench }+ \text { overage in } \mathrm{H}_{2} \text {, } \\
\text { vacuum, or inert atmosphere } \\
\text { per: } 24 \mathrm{hr} \text { at } 1550^{\circ} \mathrm{F}+\text { air cool } \\
+20 \mathrm{hr} \text { at } 1300^{\circ} \mathrm{F}+\text { air cool. } \\
\text { (AMS } 5668 \text { ) }\end{array}$ \\
\hline $\mathrm{K}-95(\mathrm{WC})$ & $\begin{array}{l}\text { Pins and } \\
\text { Plates }\end{array}$ & $R_{A} 88-90$ & $\begin{array}{l}\text { Pressed and sintered - not heat } \\
\text { treated }\end{array}$ \\
\hline $\mathrm{K}-162 \mathrm{~B}(\mathrm{TiC})$ & $\begin{array}{l}\text { Pins and } \\
\text { Plates }\end{array}$ & $\mathrm{R}_{\mathrm{A}} 87-89$ & $\begin{array}{l}\text { Pressed and sintered - not heat } \\
\text { treated }\end{array}$ \\
\hline $\mathrm{K}-801(\mathrm{WC})$ & $\begin{array}{l}\text { Pins and } \\
\text { Plates }\end{array}$ & $\mathrm{R}_{\mathrm{A}} 87-89$ & $\begin{array}{l}\text { Pressed and sintered - not heat } \\
\text { treated }\end{array}$ \\
\hline $\mathrm{LT}-2$ & $\begin{array}{l}\text { Pins and } \\
\text { Plate }\end{array}$ & $\begin{array}{l}R_{c} 52-58 \\
R_{c} 41-43\end{array}$ & $\begin{array}{l}\text { Cast, sintered, and finished- } \\
\text { not heat treated }\end{array}$ \\
\hline Metco 405SS & Plates & ${ }^{R_{A}} 61-75$ & $\begin{array}{l}\text { Anneal } 1 \text { hr at } 1400^{\circ} \mathrm{F}+\text { air cool } \\
\text { or water quench }\end{array}$ \\
\hline Molybdenum & $\begin{array}{l}\text { Pins and } \\
\text { Plates }\end{array}$ & $\mathrm{R}_{\mathrm{A}} 45-58$ & $\begin{array}{l}\text { Anneal } 1 \mathrm{hr} \text { at } 2200^{\circ} \mathrm{F} \text { in inert } \\
\text { atmosphere }+ \text { furnace or retort } \\
\text { cool }\end{array}$ \\
\hline $\operatorname{REX} 49$ & $\begin{array}{l}\text { Pins and } \\
\text { Plates }\end{array}$ & $\begin{array}{l}R_{c} 54-60 \\
R_{c} 60-62\end{array}$ & $\begin{array}{l}\text { Preheat } 1 / 2 \mathrm{hr} \text { at } 1000^{\circ} \mathrm{F}+1 / 2 \\
\text { hr at } 1650 \mathrm{~F}+\text { Austenitize } 2-5 \mathrm{~min} \\
\text { at } 2175^{\circ} \mathrm{F}+\text { salt quench to } 1000^{\circ} \mathrm{F} \\
+ \text { air cool to } 100^{\circ} \mathrm{F}+\mathrm{tr} i p l e \text { tem- } \\
\text { per per: } 3 \text { (2 } \mathrm{hr} \text { at } 1150^{\circ} \mathrm{F}+\text { air } \\
\text { cool) }\end{array}$ \\
\hline $17-4 \mathrm{PH}$ & Pins & $R_{c} 38-43$ & $\begin{array}{l}\text { Solution treat } 1 \mathrm{hr} \text { at } 1950^{\circ} \mathrm{F}+ \\
\text { rapid (airor oil) cool to below } \\
90^{\circ} \mathrm{F}+\text { termper } 4 \mathrm{hr} \text { at } 900^{\circ} \mathrm{F}+ \\
\text { air cool (H-900) }\end{array}$ \\
\hline
\end{tabular}

LMEC-70-10 
TABLE 7

HEAT TREATMENTS OF TEST MATERIALS

(Sheet 4 of 5)

\begin{tabular}{|c|c|c|c|}
\hline Material & Form & Hardness & Heat Treatment \\
\hline $17-7 \mathrm{PH}$ & Pins & $R_{c} 28-30$ & $\begin{array}{l}\text { Solution treat } 1 \mathrm{hr} \text { at } 1950^{\circ} \mathrm{F} \\
+ \text { rapid (air or oil) cool to below } \\
90^{\circ} \mathrm{F}+\text { condition austenite } 1-1 / 2 \mathrm{hr} \\
\text { at } 1400^{\circ} \mathrm{F}+\operatorname{cool} \text { within } 1 \mathrm{hr} \text { to } \\
\text { below } 60^{\circ} \mathrm{F} \text { but above } 32^{\circ} \mathrm{F} \text { and } \\
\text { hold } 1 / 2 \mathrm{hr} \text { (condition } \mathrm{T} \text { ) }\end{array}$ \\
\hline 304 SS & $\begin{array}{l}\text { Pins and } \\
\text { Plate }\end{array}$ & $\mathrm{R}_{\mathrm{A}} 48-62$ & $\begin{array}{l}\text { Solution Anneal } 1 \mathrm{hr} \text { at } 1950^{\circ} \mathrm{F} \text { and } \\
\text { water quench and cold work to } \\
\text { desired hardness }(0-20 \%)\end{array}$ \\
\hline $316 \mathrm{SS}$ & $\begin{array}{l}\text { Pins and } \\
\text { Plate }\end{array}$ & $R_{A} 55-62$ & $\begin{array}{l}\text { Solution Anneal } 1 \mathrm{hr} \text { at } 2100^{\circ} \mathrm{F} \text { and } \\
\text { water quench and cold work to } \\
\text { desired hardness }(0-20 \%)\end{array}$ \\
\hline Stellite 1 & $\begin{array}{l}\text { Pins and } \\
\text { Plate }\end{array}$ & $R_{C} 50-58$ & $\begin{array}{l}\text { Oxy-acetylene-applied hardfacing - } \\
\text { not heat treated }\end{array}$ \\
\hline Stellite 3 & $\begin{array}{l}\text { Pins and } \\
\text { Plate }\end{array}$ & $R_{c} 52-56$ & $\begin{array}{l}\text { Sand-cast material - not heat } \\
\text { treated }\end{array}$ \\
\hline Stellite 6B & $\begin{array}{l}\text { Pins and } \\
\text { Plate }\end{array}$ & $R_{C} 45-50$ & $\frac{\text { Wrought and Solution Anneal }}{\text { at } 2250^{\circ} \mathrm{F} \text { and rapid air cool }} 1 \mathrm{hr}$ \\
\hline Stellite $6 \mathrm{H}$ & $\begin{array}{l}\text { Pins and } \\
\text { Plate }\end{array}$ & $R_{c} 39-44$ & $\begin{array}{l}\text { Oxy-acetylene-applied hardfacing - } \\
\text { not heat treated }\end{array}$ \\
\hline Stellite 1016 & $\begin{array}{l}\text { Pins and } \\
\text { Plate }\end{array}$ & $R_{c} 55-60$ & $\begin{array}{l}\text { Heliarc or Oxy-acetylene-applied } \\
\text { hardfacing - not heat treated }\end{array}$ \\
\hline $\begin{array}{l}\text { Stellite } \\
\text { Star J }\end{array}$ & Pins & $R_{c} 56-63$ & $\begin{array}{l}\text { Sand-Cast material - not heat } \\
\text { treated }\end{array}$ \\
\hline Tungsten & $\begin{array}{l}\text { Pins and } \\
\text { Plate }\end{array}$ & $\begin{array}{l}\mathrm{R}_{c} 35-40 \\
\mathrm{R}_{c} 44-45\end{array}$ & $\begin{array}{l}\text { Pressed and sintered - not heat } \\
\text { treated } \\
\text { Pressed and sintered - not heat } \\
\text { treated }\end{array}$ \\
\hline $\mathrm{T} Z \mathrm{M}$ & $\begin{array}{l}\text { Pins and } \\
\text { Plates }\end{array}$ & $R_{A} 56-63$ & $\frac{\text { Stress Relieved }}{\text { and } \operatorname{cool}\left(\mathrm{H}_{2} \text { or vacuum }\right)}$. 30 min at $2250^{\circ} \mathrm{F}$ \\
\hline
\end{tabular}


TABLE 7

HEAT TREATMENTS OF TEST MATERIALS

(Sheet 5 of 5 )

\begin{tabular}{|c|c|c|c|}
\hline Material & Form & Hardness & Heat Treatment \\
\hline Udimet 630 & $\begin{array}{l}\text { Pins and } \\
\text { Plate }\end{array}$ & $R_{c} 41-45$ & $\begin{array}{l}\text { Solution Anneal } 1 \mathrm{hr} \text { at } 1950^{\circ} \mathrm{F} \\
+ \text { Age } 8 \mathrm{hr} \text { at } 1400^{\circ} \mathrm{F}\left(\text { in } \mathrm{H}_{2}\right) \\
+10 \mathrm{hr} \text { at } 1200^{\circ} \mathrm{F}\left(\text { in } \mathrm{H}_{2}\right)+\text { air } \\
\text { cool }\end{array}$ \\
\hline $\begin{array}{l}\text { Whittaker } \\
\text { NM-100 }\end{array}$ & Pins & $R_{c} 59-62$ & 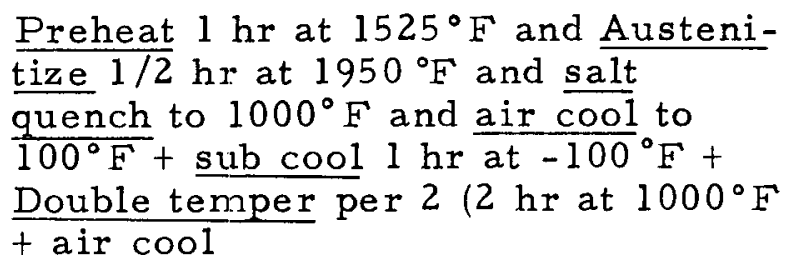 \\
\hline
\end{tabular}




\section{TEST EQUIPMENT AND PROCEDURES}

For this study, tests were made to determine basic engineering data concerning static and sliding contact characteristics of selected candidate materials in liquid and vapor sodium environments with inert cover gas at elevated temperatures. Static contact investigations were conducted at $650^{\circ} \mathrm{C}\left(1200^{\circ} \mathrm{F}\right)$ in cold-trapped and hot-trapped liquid sodium and in sodium vapor. Sliding contact tests were conducted at 427,538 , and $650^{\circ} \mathrm{C}\left(800,1000\right.$, and $\left.1200^{\circ} \mathrm{F}\right)$ in cold-trapped liquid sodium and sodium vapor. Static contact specimens were stationary pins with flat contact surfaces which rubbed against a rotating specimen plate in each test. An overall view of the equipment in which the static contact and the sliding contact investigations were performed is shown in Figure 5. A detailed description of the test equipment and procedure is presented in the following sections.

\section{A. STATIC CONTACT TESTS}

Static contact tests to determine starting friction and self-welding behavior between two similar or dissimilar materials, held against each other without motion for sustained periods of time, were conducted in sodium liquid and vapor environments at $1200^{\circ} \mathrm{F}\left(650^{\circ} \mathrm{C}\right)$. Dead-weight loading was used to press pins with spherical surfaces into contact with a flat plate surface. Static contact tests were made on two groups of candidate material combinations; the first group contained 49 material combinations, and the second group contained 54 material combinations.

\section{Description of Static Contact Test Equipment and Specimens}

A perspective and schematic layout of the static contact test equipment is shown in Figure 6 and a cross-section of the apparatus is shown in Figure 7. Specimen pins and plate are shown in Figures 8, 9, and 10.

A test combination consisted of three $0.635-\mathrm{cm}$ (1/4-in.)-diameter pins, each of the same material, with spherical contact surfaces being pressed by a gravity load of $7.44 \mathrm{~kg}(16.38 \mathrm{lb})$ against a plate of either the same or different canidate material. Pin and plate contact surfaces were polished to 5 to $7 \mu \mathrm{in}$. Each pin set was arranged in an equilateral triangle lattice with equal loading from a cylindrical weight being applied through a ball joint located above the

$$
\text { LMEC-70-10 }
$$




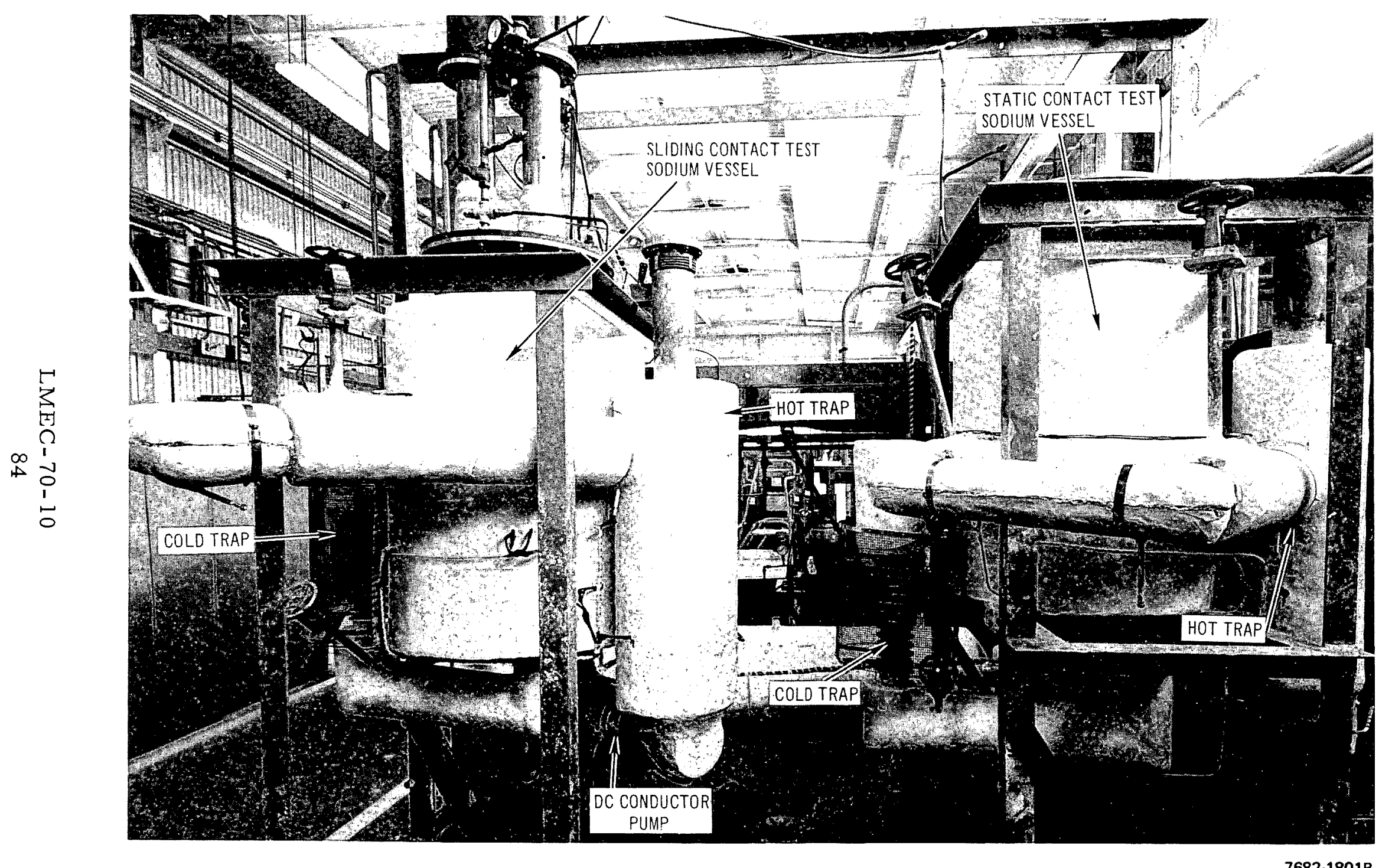

Figure 5. Static Contact and Sliding Contact Apparatus 

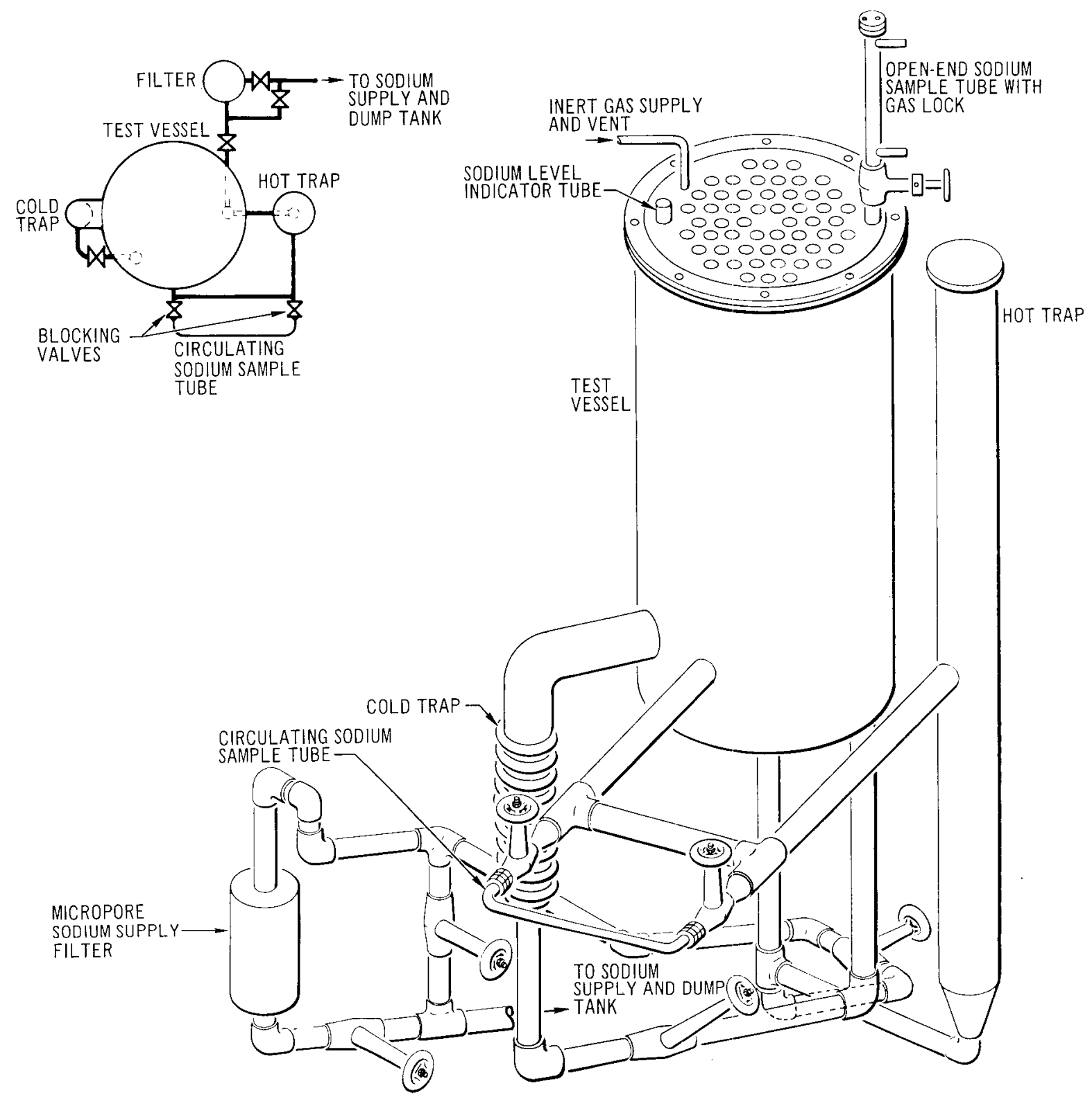

Figure 6. Static Contact Test Process Schematic

$7694-2550$ and Perspective Layout 


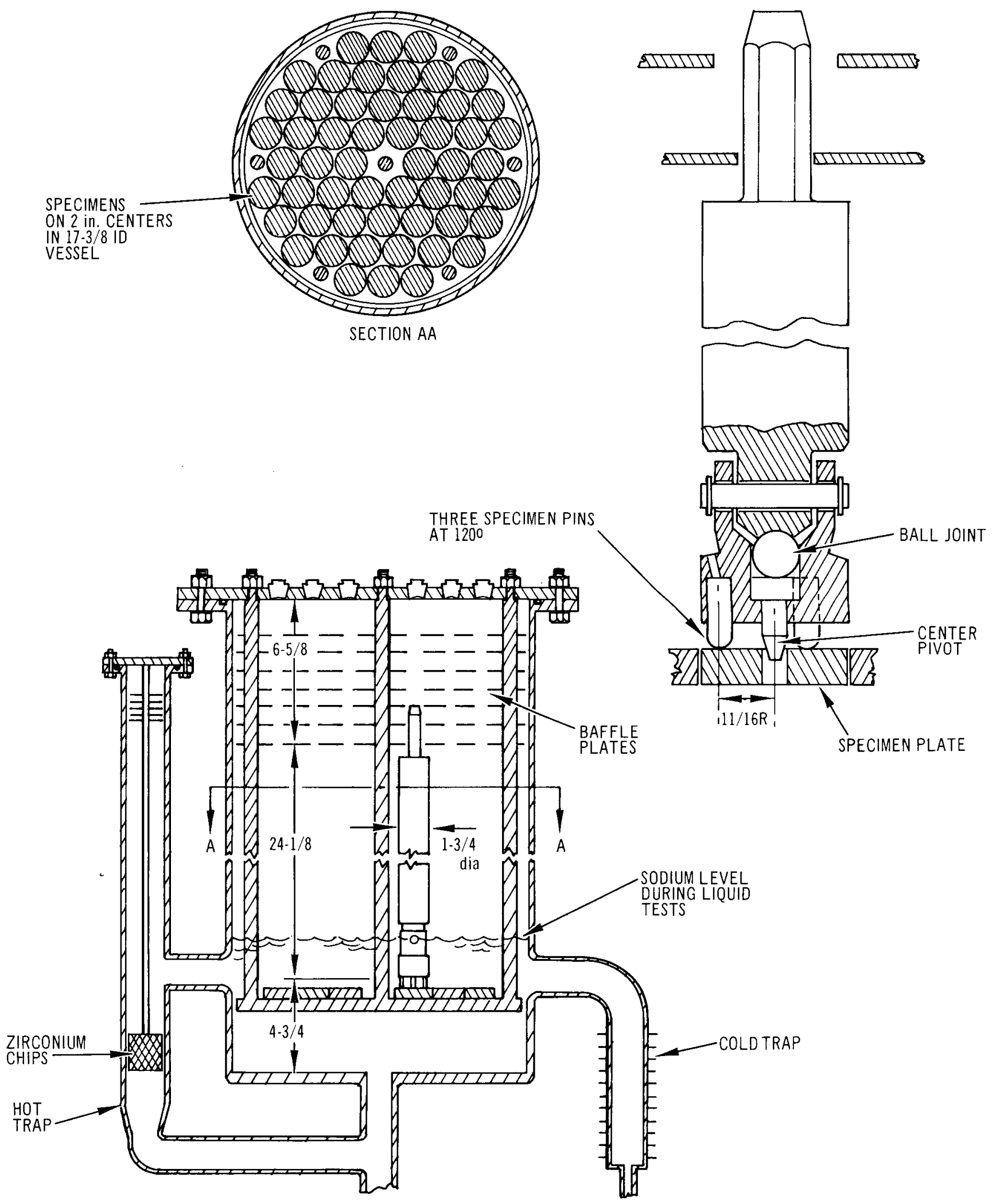

7694-2527

Figure 7. Static Contact Apparatus

LMEC-70-10 


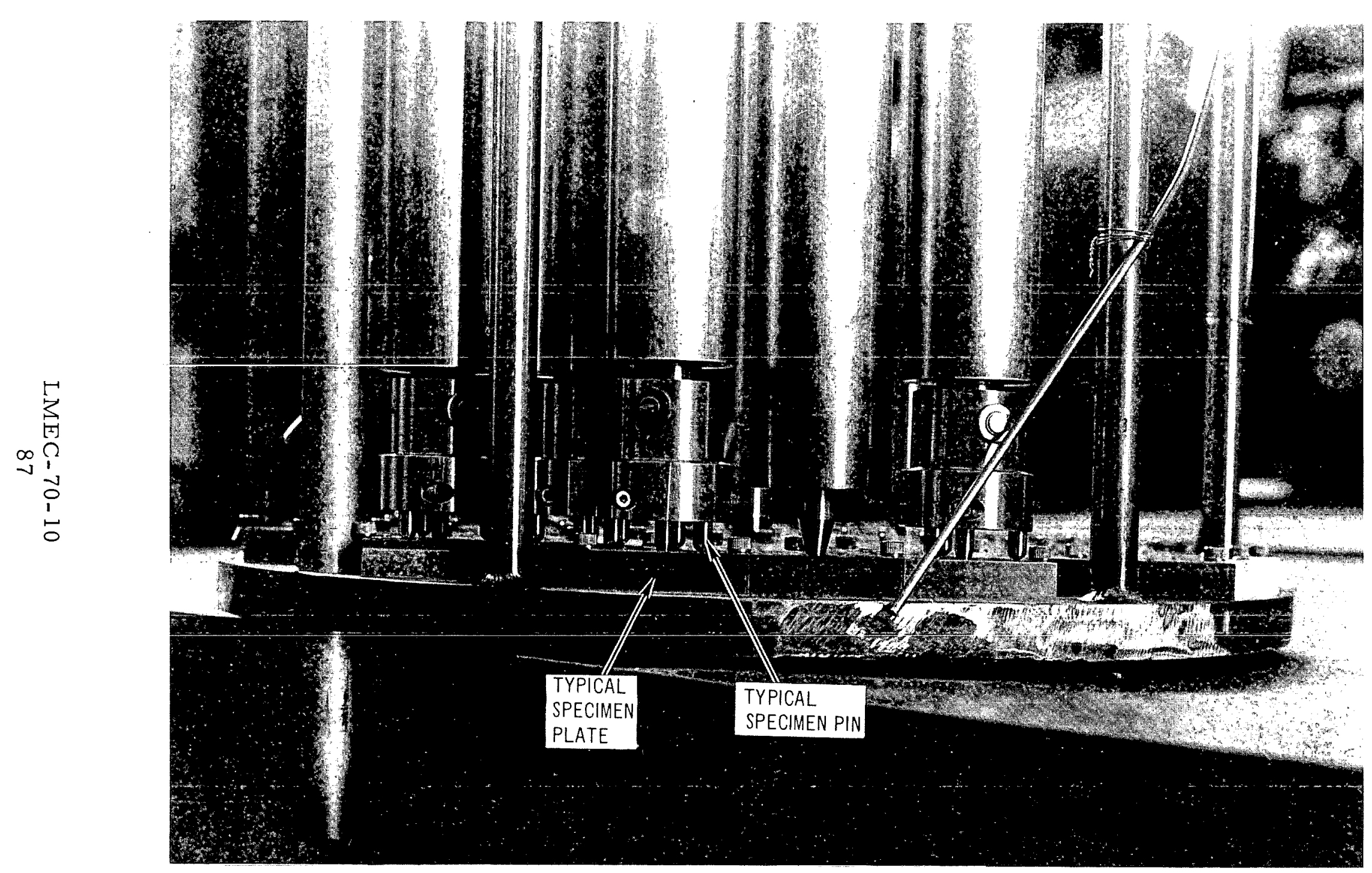

Figure 8. Static Contact Apparatus - Typical Pins and Plate Arrangements 


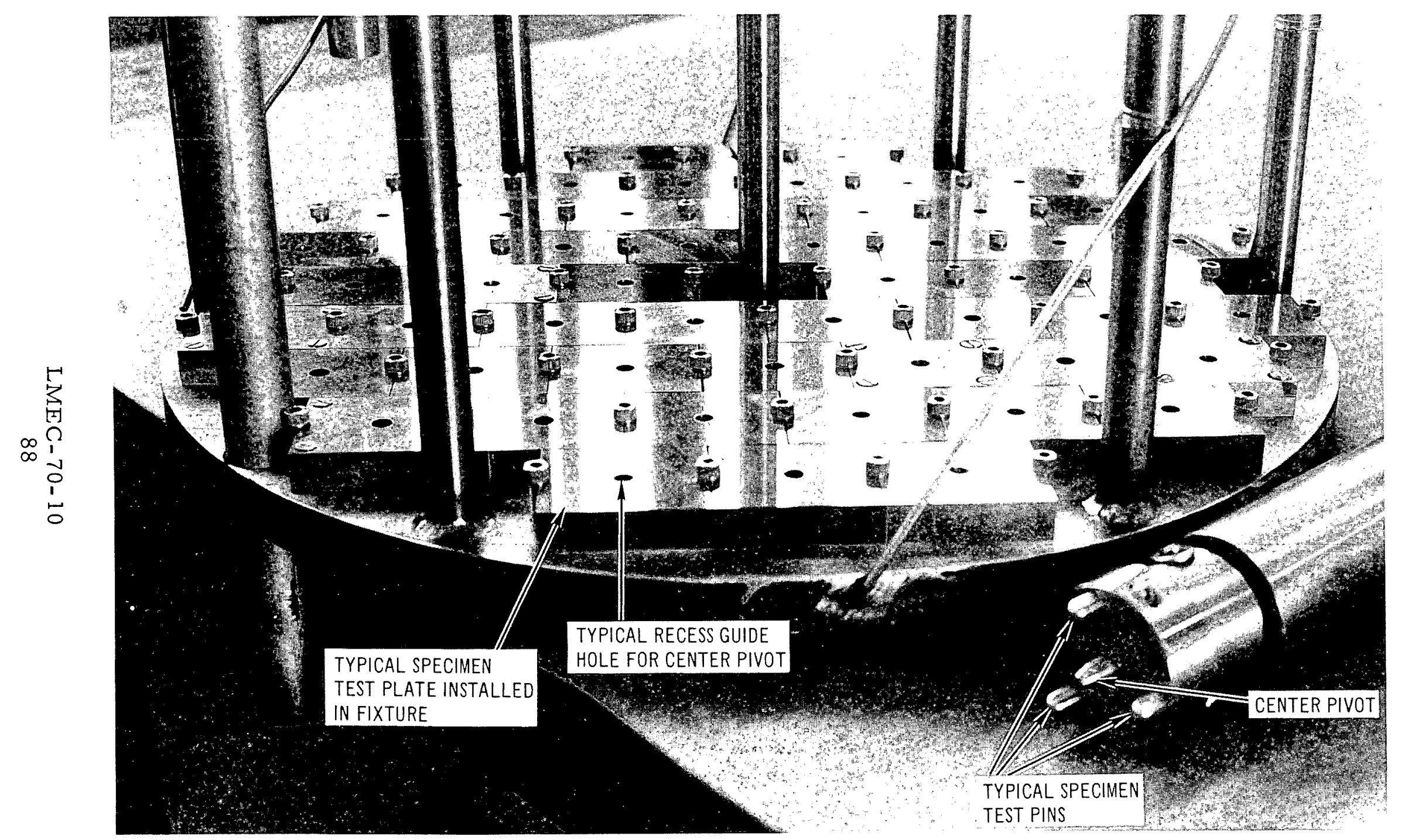

Figure 9. Static Contact Apparatus Showing Plates Installed 


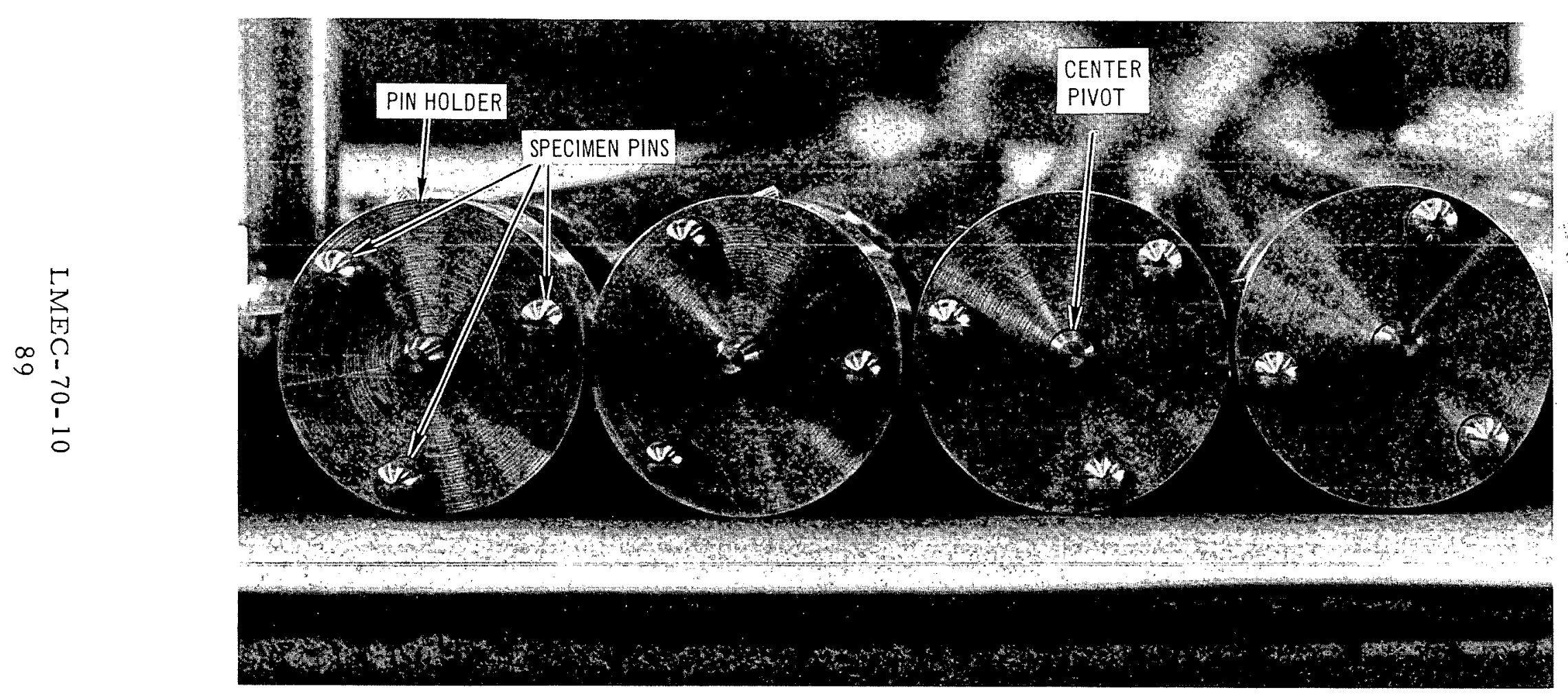

Figure 10. Static Contact Apparatus Showing Specimen Pins

7682-1806B 


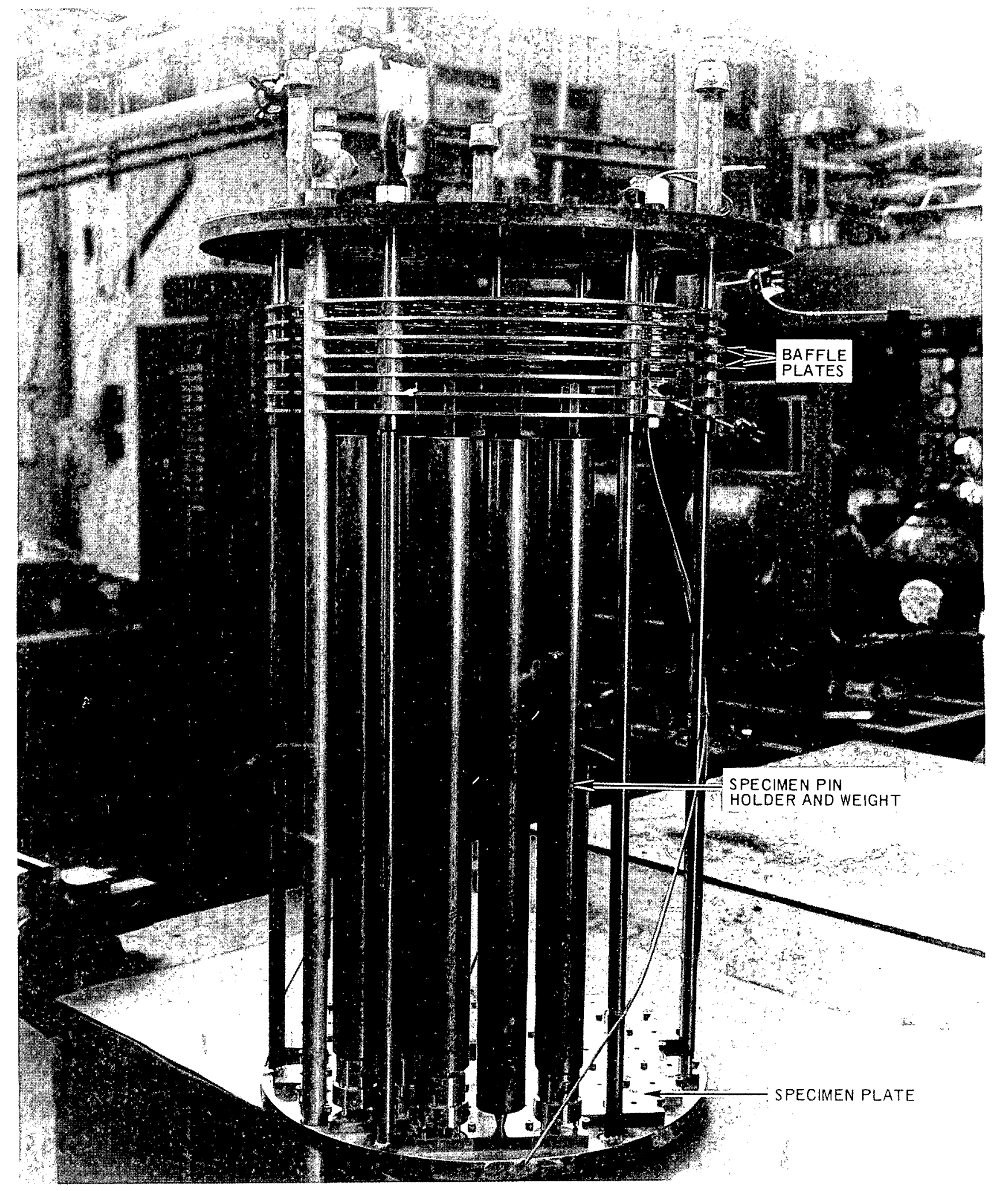

7682-1809A

Figure 11. Static Contact Apparatus Showing Specimen Pins and Plates in Support Fixture

\section{LMEC-70- 10}


pin assembly holding device. The pin assembly device contained a center rotation guide pin which ran through an oversized recess hole in the specimen test plate. The respective center guide pin did not support any weight. Pin-plate material combinations with their individual cylindrical load weights and test fixture were randomly arranged in a support fixture (see Figure 11) equipped with baffle plates to condense sodium vapor and minimize both test temperature fluctuations and heat losses. The test apparatus, including cyclindrical weights and thermal baffles, was constructed of Type 304 stainless steel.

The assembled test apparatus was placed in a Type 304 stainless-steel test vessel with associated process loop equipment as shown in Figure 6 and 7. A cover plate with a Buna-N polymer rubber O-ring, cooled by flowing water in coils of copper tubing, closed the vessel. Ports, closed with plugs, were provided in the cover plate directly above each pin-plate test combination. Teflon and Glyptal were used to seal the plugs in the cover plate ports.

A 1/2-in.-ID Type 304 stainless-steel tube, sealed at the lower end, penetrated the cover plate and extended to the bottom of the test vessel; it was used for inserting an induction coil sodium level indicator. Another similar tube, open at both ends, also penetrated the cover plate; this was employed to obtain sodium samples in conjunction with a gas lock which was located above the tube top end. Connected to the test vessel was a Type 304 stainless-steel, 1-in.-ID circulation process loop; attached to the latter were two lines, each with blocking valves, which led to the sodium supply and dump tank. A double, Micropore $(5 \mu)$ stainless-steel filter was located in the sodium supply line. A cold trap, hot trap, and circulating-type of sodium sampler were part of the process loop along with necessary valves.

Relative locations of the cold trap and hot trap are illustrated in Figures 6 and 7. Electric resistance heaters and thermocouples were attached to the test vessel, supply tank, lines, valves, and process components. The entire test facility was insulated with high-temperature lagging.

Liquid sodium was circulated by thermal drive through the test vessel and process loop; loop temperature differentials caused by cold trap and/or hot trap operation provided the convection forces involved. Calculated sodium flow based on heat input to the system exceeded $1 / 8 \mathrm{gpm}$. System sodium capacity was 8.3 gal. 
By means of adjustment of the sodium level in the vessel, a test surface environment of either sodium vapor or liquid could be provided.

The test vessel and sodium supply and drain tank atmosphere chambers were connected to an inert gas (argon) supply and vent system equipped with rupture disks and relief valves. Argon gas purging was employed to remove air from the vessel atmosphere before sodium was introduced. A gas pressure of 1 in. $\mathrm{Hg}$ above atmospheric was maintained in the vessel during test periods.

\section{Test Procedure for Static Contact Tests}

Static contact tests were made on two groups of candidate materials at $650^{\circ} \mathrm{C}$ $\left(1200^{\circ} \mathrm{F}\right)$. In the first group, 49 combinations were assembled and tests were run in environment sequences, without removal from the test vessel, as follows: (1) $\sim 1$ month in cold-trapped liquid sodium, (2) $\sim 2$ months in cold-trapped liquid sodium, (3) $\sim 1$ month in hot-trapped liquid sodium, and (4) $\sim 1$ month in sodium vapor over cold-trapped liquid sodium. In the second group, 54 combinations were run in environment sequence as follows: (1) $\sim 1$ month in cold-trapped liquid sodium, (2) $\sim 2$ months in cold-trapped liquid sodium, (3) $\sim 1$ month in hottrapped liquid sodium, and (4) $\sim 1$ month in sodium vapor over cold-trapped liquid sodium. No pin removal occurred between the foregoing static contact exposures.

To initiate these tests, the pin-plate combinations were solvent-cleaned with reagent-grade acetone, assembled in the test fixture, and the test apparatus was loaded in the test vessel; an argon gas purge was employed to flush air from the vessel atmosphere. The test vessel and loop were then filled with sodium by gas pressurization of the sodium supply and drain tank. This forced sodium through a slightly opened blocking valve and filter and into the system. During a filling for a test in liquid sodium, the filling operation was intermittent to permit removal of excess oxygen from the sodium by the cold trap or hot trap. Thus, when liquid sodium reached the test surfaces, the contaminant oxygen content was within the proper range.

The air-cooled cold trap was operated at a surface temperature of $138 \pm 3^{\circ} \mathrm{C}$ $\left(280^{\circ} \mathrm{F}\right)$. When hot-trapping was performed, the cold trap was isolated from the system. Zirconium sponge was employed as the hot-trap gettering agent and was heated to $704 \pm 5^{\circ} \mathrm{C}\left(1300^{\circ} \mathrm{F}\right)$. 
Temperatures of the liquid sodium in the test vessel and the various system support components were measured by means of thermocouples with the readouts plotted on recorders with built-in standardization balances.

Calibrated torque indicators were used to measure the forces necessary to initiate movement and to thus determine the static and breakaway coefficients of friction. Torque measurements were made at the beginning of the run of environment sequences for each group and after a test was conducted for a specific time period in a particular $650^{\circ} \mathrm{C}$ sodium environment. In each case, the forces measured were those required to place each set of pins into motion, and not those required to maintain motion. The pin assembly was rotated a small angular amount against the contact plate after each measurement and thus provided a fresh site on the specimen plates for the succeeding measurements.

When measuring torques required to rotate a pin assembly, the port plug concerned was removed from the vessel coverplate after being fitted with a gas retention boot. A torque meter extension shaft was inserted through the boot and port for connection to the top of each weighted pin assembly shaft. Continuous addition of argon to the gas retention boot during this action minimized air contamination inside the test vessel.

After a test series was completed on a material combination group, the sodium was drained, the test vessel and contents were cooled to ambient, and pin and plate test specimens were removed from the vessel and cleaned.

Sodium samples for analysis were obtained by a dip-tube method. Apparatus for dip-tube sampling through a test vessel cover plate consisted of a vertically oriented gas lock (14 in. long, 1 in. in diameter) equipped with a gate valve at the bottom end and and $\mathrm{O}$-ring gland on the top end which accommodated a 3/8in.-OD stainless-steel sample dip tube fitted with an orifice plug. Two nipple connections attached to the gas lock admitted fresh inert purge gas and removed exhausted purge gas through a relief valve to the vent system.

The following steps were followed to obtain a dip-tube sodium sample:

1) With the gate valve on the gas lock in closed position, a cleaned stainless-steel sample tube was inserted through the O-ring gland.

2) The top end of the sample tube was attached to a flexible tube which in turn was connected to a roughing-in vacuum pump through a blocking valve. 
3) The interior of the stainless-steel sample tube and gas lock were pumped down to a rough vacuum, the vacuum pump was valved off, and inert gas to $1-$ in. Hg pressure was introduced into the sample tube and gas lock. The pumping down and inert gas filling cycle was repeated eight times.

4) Inert gas was introduced at 1 -in. Hg pressure into the gas lock and sample tube. This pressure was the same as the cover gas pressure in the test vessel.

5) After opening the gas lock gate valve, the sample tube was lowered to the bottom of the test vessel sodium pool.

6) Sodium was allowed to enter the sample tube by valving the flexible tube (on the top end of the sample tube) to the vent nipple on the gas lock. This step equalized inert gas pressure inside the sample tube with that of the test vessel.

7) The sample tube was raised to permit the sodium to completely drain from the tube interior; then, the tube was lowered again to the bottom of the vessel and sodium reentered the bottom of the sample tube. This step was repeated at least 3 times for the purpose of obtaining representative sodium in the sample tube.

8) While the sample tube was submerged in the sodium pool, a shutoff pinch clamp was snapped onto the flexible tube (attached to the top end of the sample tube); the sample tube was raised until the tube bottom end cleared the gas lock valve gate which was then closed.

9) The sample tube bottom end filled with sodium was maintained inside the gas lock inert atmosphere until the sodium cooled and solidified at room temperature. At this time, the sample tube was removed from the gas lock and the bottom portion of the sample tube was crimped off and removed for chemical analysis.

Originally, the stainless-steel sample tube was cleaned by means of a flush with acetone and an inert gas dry. A later, superior, cleaning method, developed during the test program, consisted of: (1) acid cleaning with a diluted nitrichydrofluoric acid mixture, (2) deionized water rinsing, (3) acetone rinsing, and, (4) flame drying while purging dry argon gas through the tube. 
Equivalent oxide concentration analysis was conducted by the Pepkowitz amalgamation method.

\section{Measurement Techniques for Static Contact Tests}

Calibrated Torque Breakaway Gauge(s), Models TG 48RI and TC 108RI, Torque Controls Inc., were used to determine the torques necessary to set the pins in motion and determine the static contact and breakaway coefficients using the formula $\mu=F / L$. These instruments were calibrated in inch-ounces and registered the maximum resistance torque applied to effect motion of the pinplate combinations.

Pin and plate material specimens were examined and photographed after a completed environment sequence. Creep deformation of the pin materials at elevated temperatures caused contact flat spots on the pin spherical surfaces, which varied with material. By means of a Tukon Machine, using a microscope at $50 \mathrm{X}$ magnification, with a calibrated etch grid overlay plate, the contact areas were determined which developed on the pins. The contact area summation of the three pins in each pin-plate were recorded as the pin contact area:

$$
A_{T}=A_{1}+A_{2}+A_{3}
$$

where

$$
\begin{aligned}
& A_{T}=\text { contact area of all pins at end of tests. } \\
& A_{i}=\text { contact area of pin. }
\end{aligned}
$$

The minimum stress was then calculated as follows:

$$
P=\frac{L}{A_{T}} \text {, }
$$

where

$$
\begin{aligned}
P= & \text { minimum surface pressure stress } \\
L= & \text { total weight, corrected for buoyancy effects, imposed on the three } \\
& \text { pins. }
\end{aligned}
$$




\section{B. SLIDING CONTACT TESTS}

Sliding contact tests to determine kinetic friction coefficients and wear coefficients of selected material combinations under various conditions were conducted in sodium.

\section{Description of Sliding Contact Test Equipment and Specimens}

The sliding contact tests to determine friction and wear behavior of candidate materials in liquid and vapor sodium consisted of three stationary flat-head pins bearing against a rotating plate (disk). A perspective and schematic layout of the sliding contact test equipment is shown in Figure 12 and a cross section of the apparatus is shown in Figure 13. Typical pin and plate material specimens are shown in Figure 14 and the test fixture and components are shown in Figure 15.

A test combination consisted of three pins of different rubbing surface diameters $(0.518,0.569,0.635 \mathrm{~cm}),(0.204,0.224$, and $0.250 \mathrm{in}$.$) each of the same$ material (Figure 16), which were held in vertical position in a triangular lattice below a rotating test plate (Figure 17) of the same or a different specimen material. Pin and plate contact surfaces were ground to less than $10-\mu$ in. finish. The pins were located 120 degrees apart at different radial distances 14.762 , 3.969 , and $3.175 \mathrm{~cm})(1.875,1.562$, and 1.250 in.) from the plate axis; this caused three separate wear paths on the plate. As arranged, the larger-diameter pin ran along the inboard wear path, and vice versa.

Each test loading was applied through a flexible joint with the center of gravity at the plate axis. This permitted a balanced load distribution. Due to dimensions and configurations used, an equal pressure was applied to each pin sliding surface.

Pin-plate material combinations, with their respective individual cylindrical load weights, were assembled in a test fixture equipped with baffle plates to minimize test temperature fluctuations and heat transfer. A Cerrobend liquid seal was installed on each drive shaft assembly to prevent air from contaminating the vessel atmosphere. Above the Cerrobend seal, two ball bearings aligned the shaft in the fixture housing. A 1/3-hp, variable-speed-drive, dc motor with gear head reducer rotated each drive shaft through a slip clutch. 

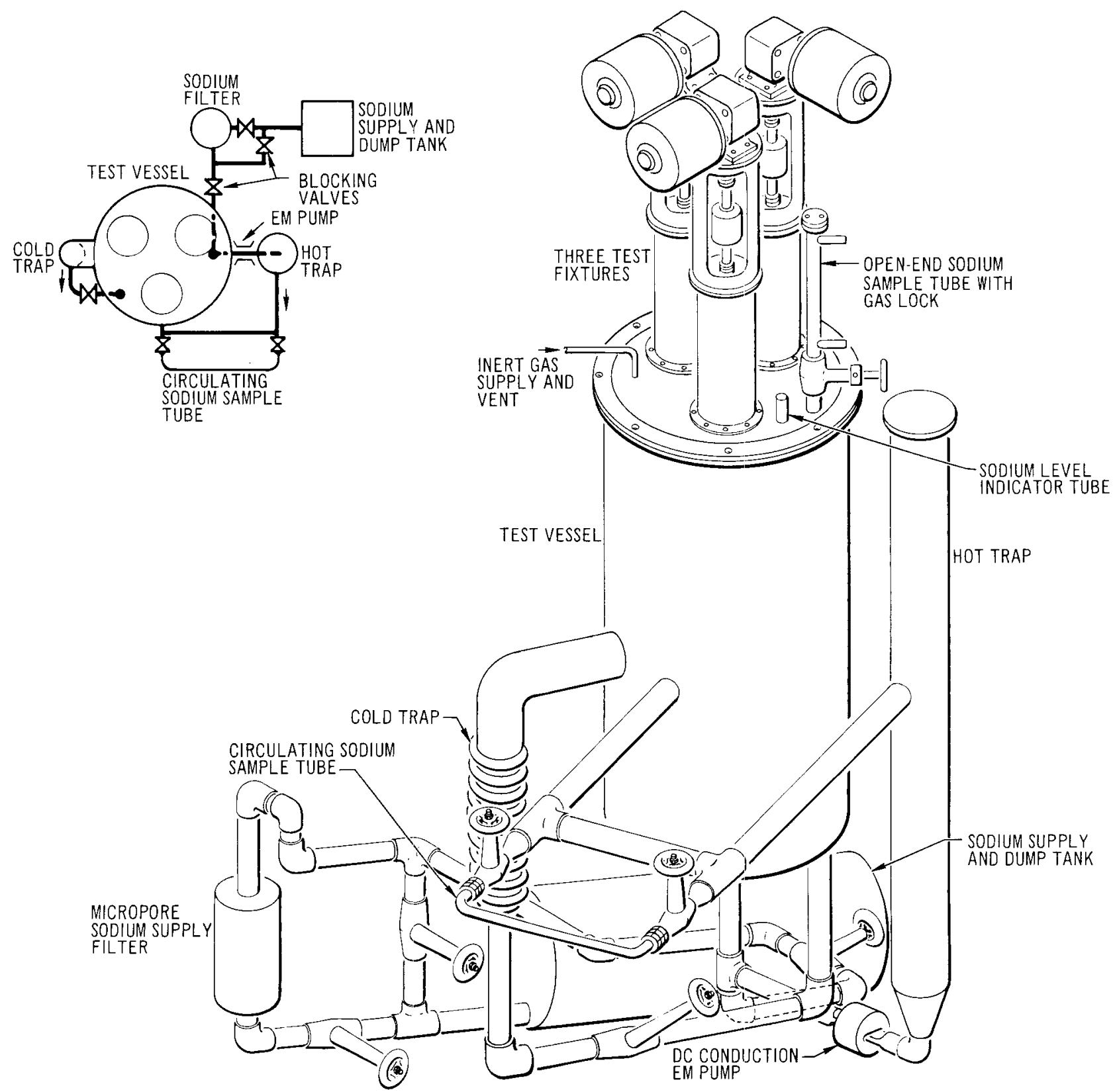

$7694-2549$

Figure 12. Sliding Contact Test Process Schematic and Perspective Layout 


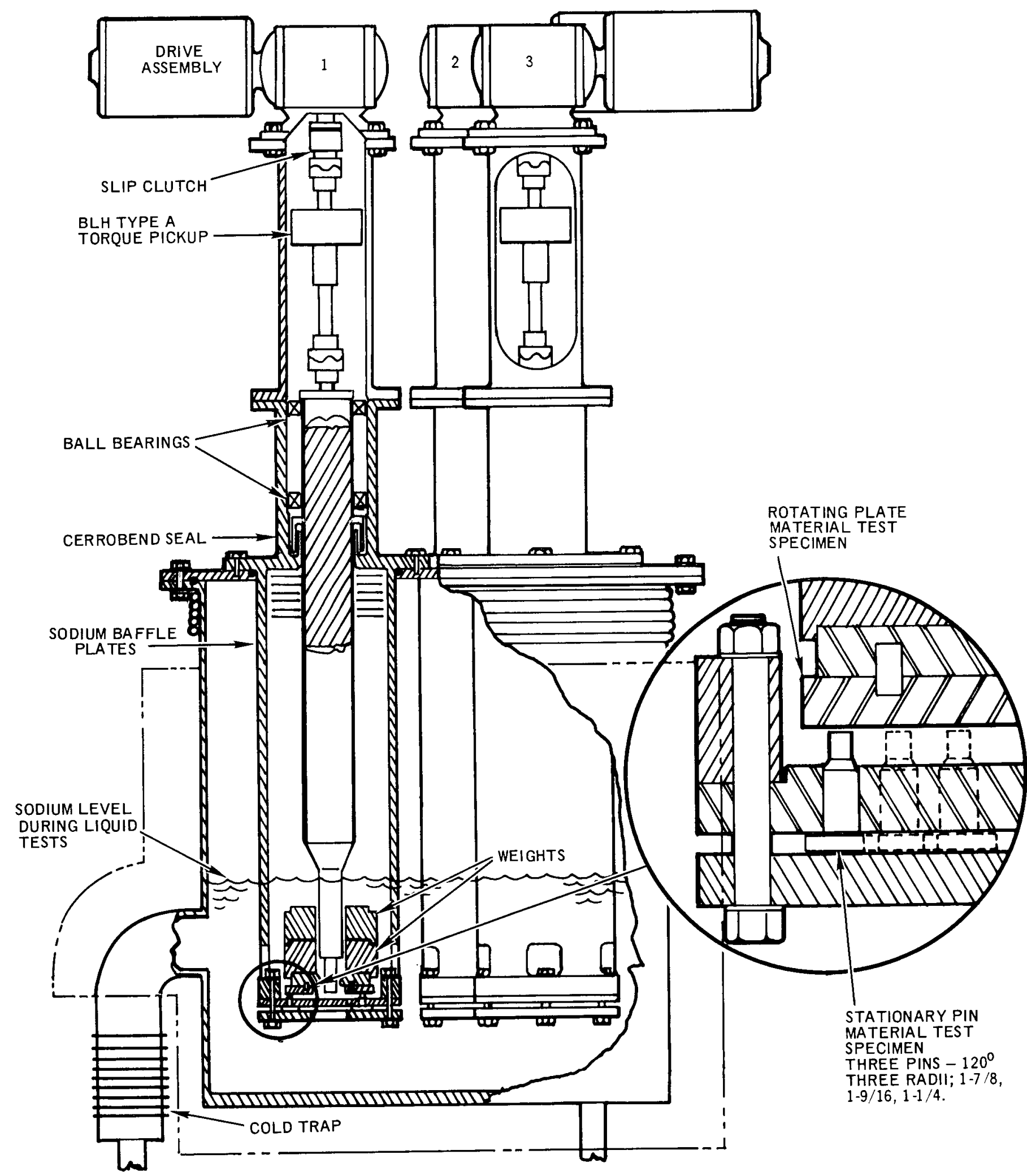

$7694-2526$

Figure 13. Sliding Contact Apparatus

LMEC-70- 10 


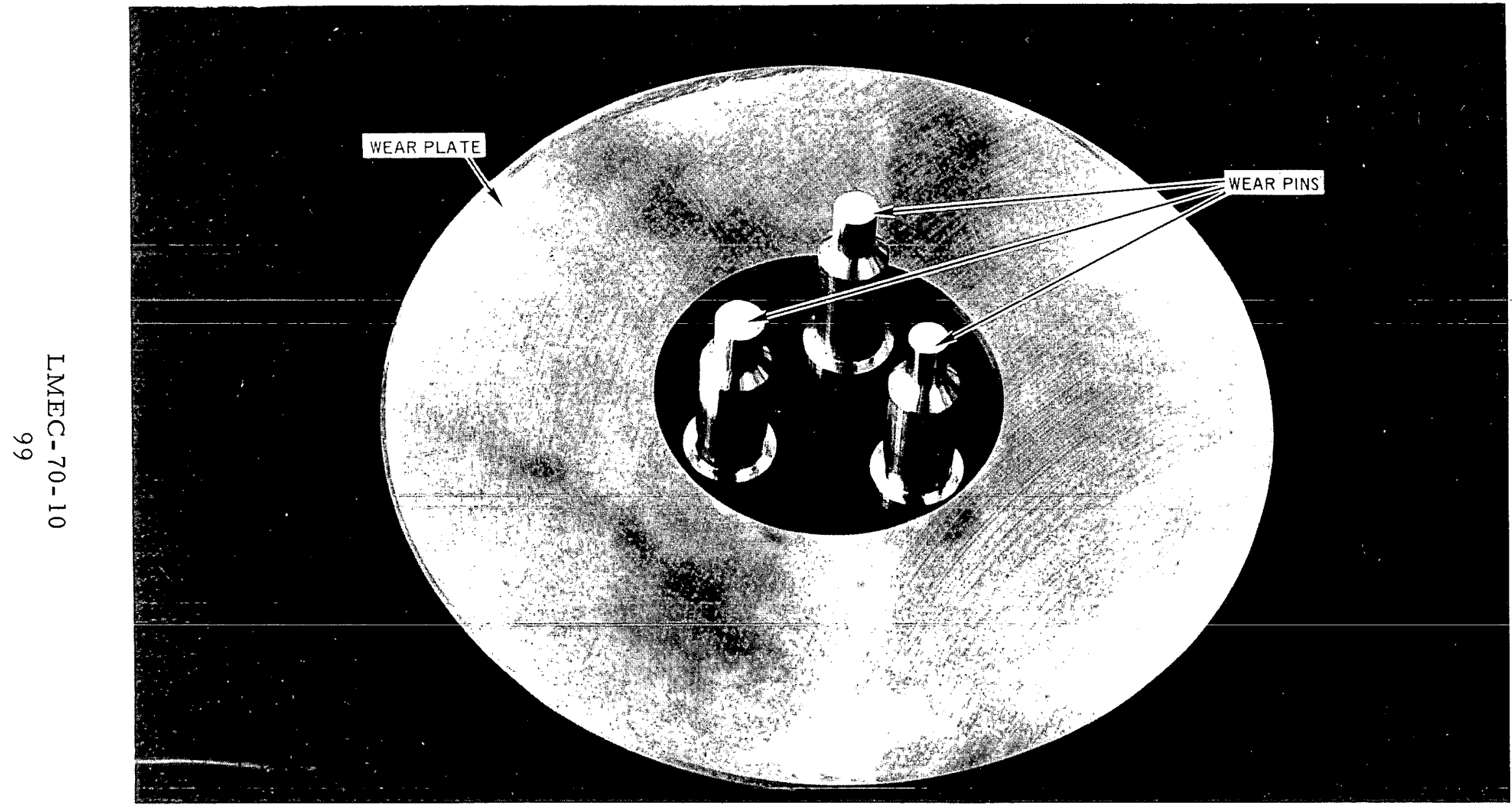

Figure 14. Typical Sliding Contact Wear Plate and Pins 


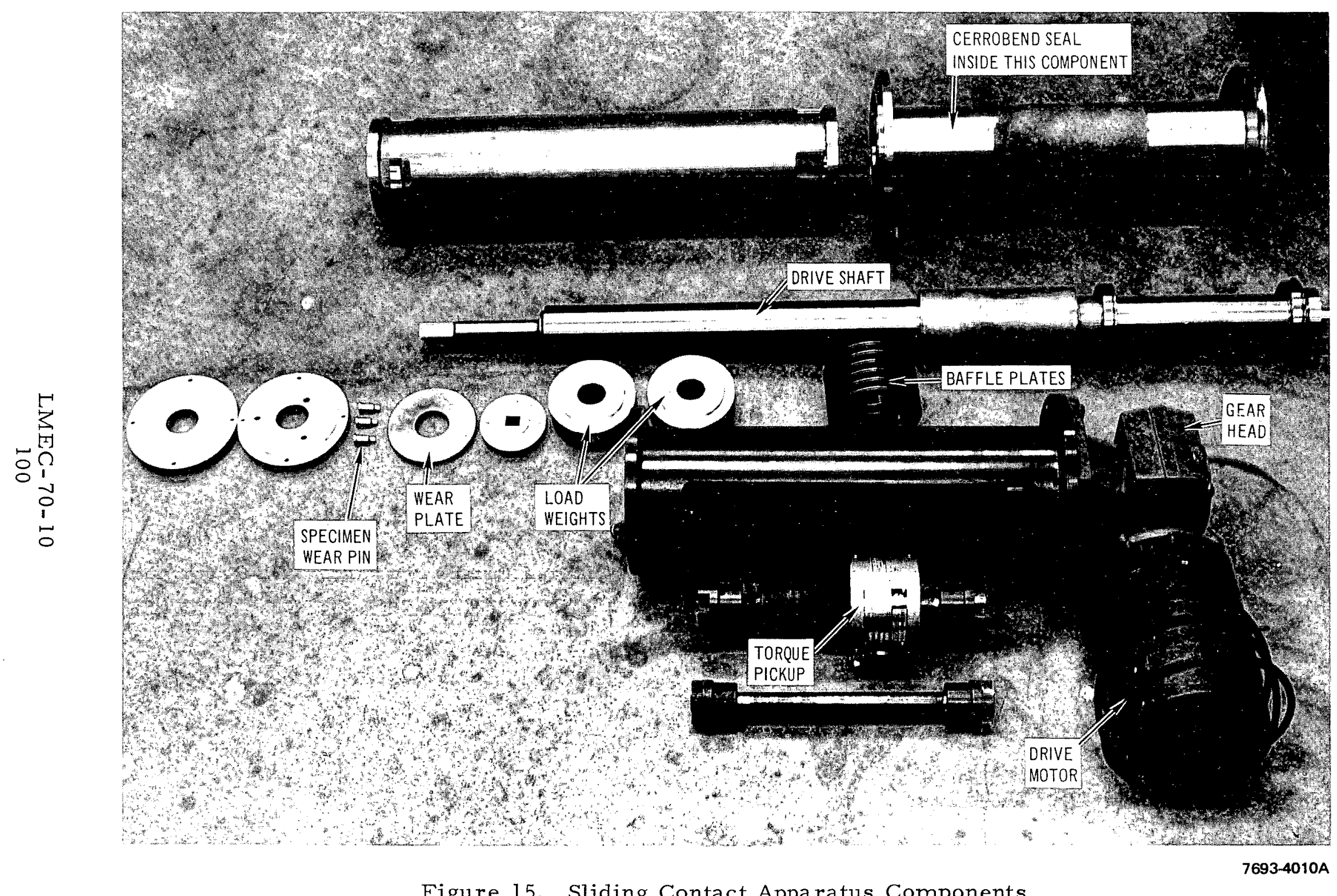

Figure 15. Sliding Contact Apparatus Components 


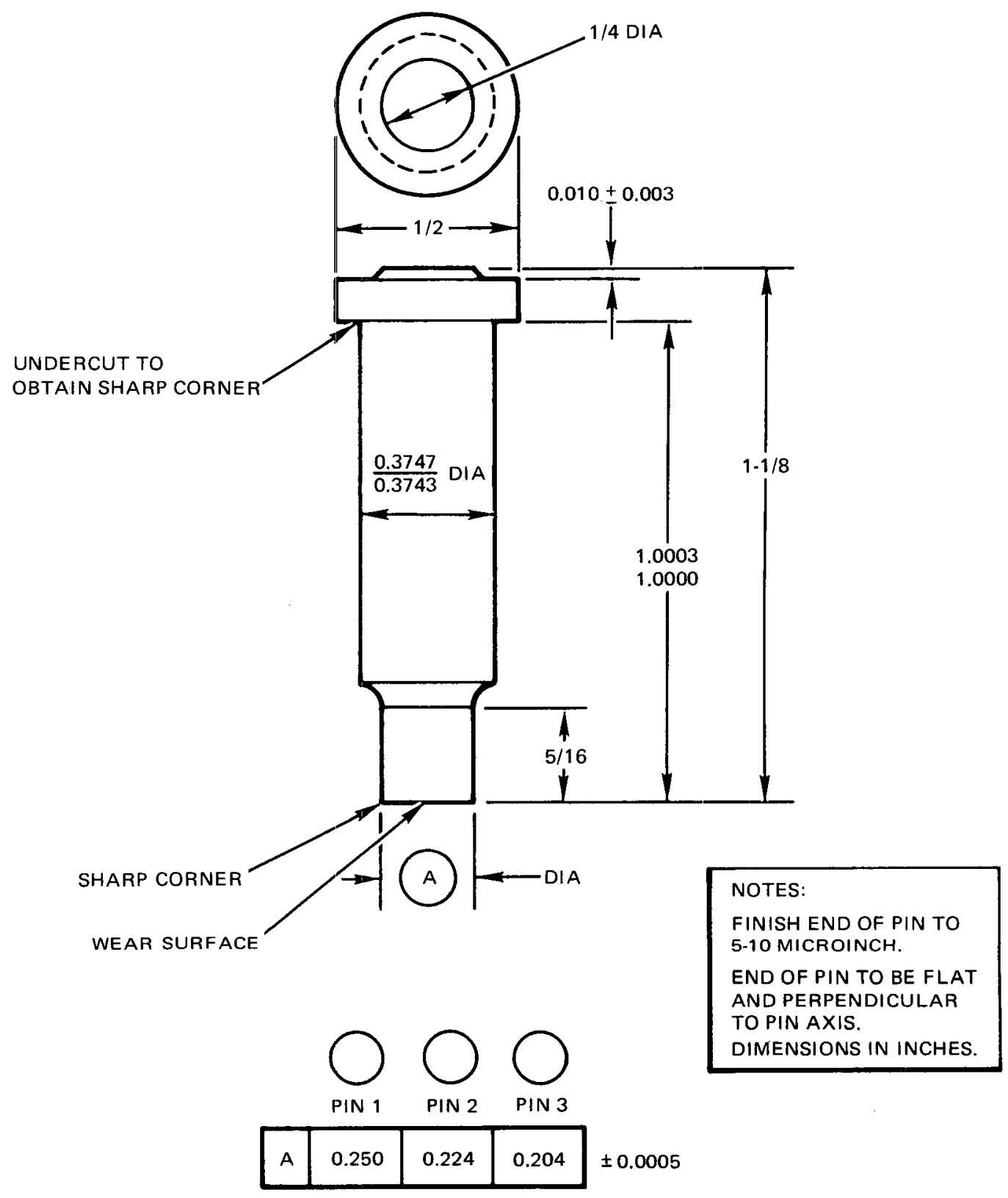

$7693-4732$

Figure 16. Pin Configuration - Engineering Drawing 


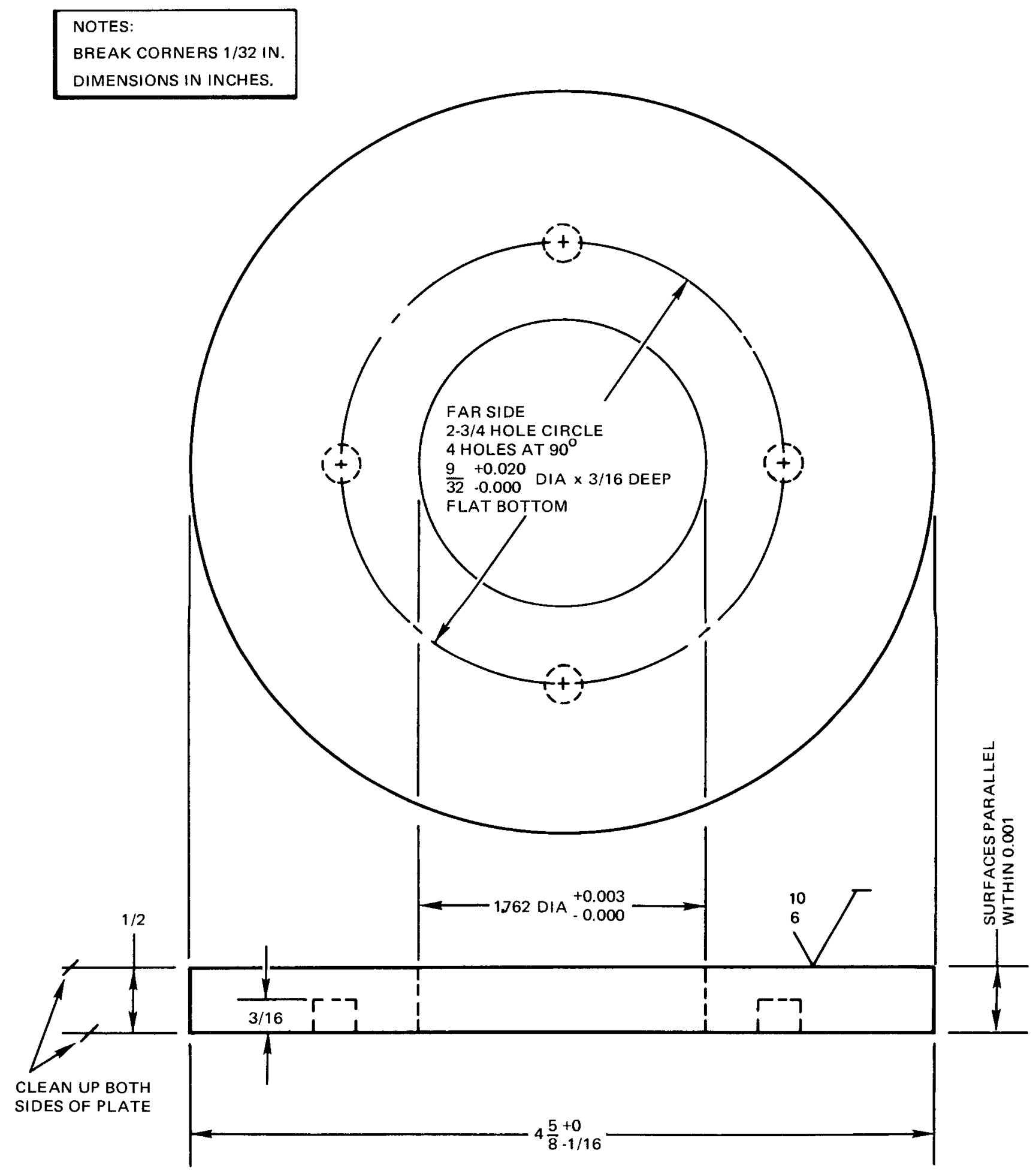

Figure 17. Plate Configuration - Engineering Drawing 
Most of the sliding contact tests were conducted in the principal test vessel shown in Figure 5; the remaining tests were conducted in vessels similar to the principal test vessel, but which could hold only one setup. To run sliding friction and wear tests in the principal test vessel, three test fixtures with pinplate combinations, each consisting of three pins and one disk plate, were placed in the Type 304 stainless-steel-alloy vessel through ports in the Type 300 series stainless-steel cover plate. Static seals associated with the cover plate were of Buna-N polymer rubber; the large peripheral seal was cooled by flowing water in coils of copper tubing. A 1/2-in.-ID Type 304 stainless-steel tube, sealed at the lower end, penetrated the cover plate and extended to the bottom of the test vessel; it was used for insertion of an induction coil sodium level indicator. Another similar tube, open at both ends, also penetrated the cover plate; this was employed to obtain sodium samples in conjunction with a gas lock which was located above the tube top end.

The test vessel and sodium supply and drain tank atmosphere chambers were connected to an inert gas (argon) supply and vent system equipped with rupture disks and relief valves. Gas pressure of 1-in. Hg above atmospheric was maintained in the vessel during test periods. Argon gas purging was employed to remove air from the vessel atmosphere before sodium was introduced.

To fill the test vessel and loop with sodium, gas pressure was increased in the sodium supply and drain tank. This forced sodium through the slightly open blocking valve and filter and into the system. A double, Micropore (5- $\mu$ ) stainless-steel filter and blocking valve was located on the l-in.-diameter sodium supply line; only a blocking valve was placed on the l-in.-diameter dump line. Either a sodium vapor or liquid test environment could be applied, depending upon the sodium level in the test vessel.

Electric resistance heaters and thermocouples were attached to the test vessel, supply tank, lines, valves, and process components. The entire test facility was insulated with high-temperature lagging.

Liquid sodium was circulated by thermal drive through the test vessel and process loop; loop temperature differentials caused by cold trap and/or hot trap operation provided the convection forces involved. Calculated sodium flow based on heat input to the system exceeded $1 / 8 \mathrm{gpm}$. The air-cooled cold trap was 
operated at a surface temperature of $138 \pm 3^{\circ} \mathrm{C}\left(280^{\circ} \mathrm{F}\right)$. When tests with hottrapped sodium were performed, the cold trap was isolated from the circulating system. Zirconium sponge heated to $704 \pm 5^{\circ} \mathrm{C}\left(1300^{\circ} \mathrm{F}\right)$ was employed as the hot-trap gettering agent.

Sodium sampling and oxygen analysis were performed in the same manner as that described for the static contact tests.

\section{Test Procedure for Sliding Contact Tests}

Sliding friction and wear tests were conducted on 43 candidate materials at temperatures ranging from $500^{\circ} \mathrm{F}\left(260^{\circ} \mathrm{C}\right)$ to $1200^{\circ} \mathrm{F}\left(650^{\circ} \mathrm{C}\right)$ in both liquid and vapor sodium, cold-and/or hot-trapped, and pin pressures ranging from 30 to 130 psi, with the majority near the latter stress load.

After the pin-plate combinations were solvent-cleaned with reagent grade acetone, assembled in the test fixture, and loaded in the test vessel, an argon gas purge was employed to remove air from the vessel atmosphere. The test vessel and loop were filled with sodium, by gas pressurization of the supply tank, and the sodium circulated by thermal drive through the cold trap (or hot trap) until oxygen impurity reached equilibrium at 20 to $30 \mathrm{ppm}$. Test temperatures of the liquid sodium and various system support components were measured by means of thermocouple readouts on recorders with built-in standardization balances. Temperature levels across the vessel were maintained within $\pm 10^{\circ} \mathrm{F}$ during tests. The forces required to rotate a specimen plate on the three specimen pins were measured at the beginning and end of test and during the test period to indicate frictional trends. In each case, the forces measured were those required to maintain motion. This was accomplished by removing a section from the test fixture shaft above the Cerrobend seal, installing a calibrated torque pickup, and recording the signal output in inch-pounds on a chart readout device.

After concluding a test, the sodium was drained, the test vessel and contents were cooled to ambient, and pins and plates were removed, cleaned, and examined. 


\section{Measurement Techniques for Sliding Contact Tests}

a. Coefficient of Friction Measurements

A Baldwin-Lima-Hamilton (BLH) SR-4 torque pickup unit was used to measure the torques required to rotate a specimen plate on the three specimens pins. Accuracy of the BLH torque pickup was calibrated at $\pm 0.3 \%$, but fluctuations in the power supply may have limited system accuracy to $\pm 2.5 \%$. Signals from the BLH unit were obtained while the variable speed drive motor of the fixture was being controlled by a Ratiotrol 1/3-hp Motor Speed Control, Model R-33, to the prescribed test $\mathrm{rpm}$. These signals, minus null readings, were recorded on a Visicorder Model 1108. These Visicorder readings included the tare torque required to turn the drive shaft with the Cerrobend seal. This tare torque was determined on a fixture prior to each test run. The tare torque was subtracted from the Visicorder values and the results were used to calculate friction values under dynamic conditions using the formula $\mu=F / L$.

The load, L, was calculated from the total weight, w, supported by the three pins, corrected for buoyancy effects. Each pin was a different distance from the center of the rotating, weighted plate, so the load on each pin differed (though the cross-sectional areas, $A_{i}$, were so related that the pressure on each of the three pins was the same). Labeling the coefficients of friction of each pin $\mu_{1}, \mu_{2}$, and $\mu_{3}$, and the load carried by each pin, $\mathrm{w}_{1}, \mathrm{w}_{2}$, and $\mathrm{w}_{3}$,

$$
\begin{gathered}
F=\mu_{1} \mathrm{w}_{1}+\mu_{2} \mathrm{w}_{2}+\mu_{3} \mathrm{w}_{3} \\
\mu_{\text {measured }}=\frac{\mathrm{F}}{\mathrm{w}}=\left(\frac{\mathrm{w}_{1}}{\mathrm{w}}\right) \mu_{1}+\left(\frac{\mathrm{w}_{2}}{\mathrm{w}}\right) \mu_{2}+\left(\frac{\mathrm{w}_{3}}{\mathrm{w}}\right) \mu_{3} .
\end{gathered}
$$

Also, the system was so designed that

$$
\frac{\mathrm{w}}{\mathrm{A}}=\frac{\mathrm{w}_{1}}{\mathrm{~A}_{1}}=\frac{\mathrm{w}_{2}}{\mathrm{~A}_{2}}=\frac{\mathrm{w}_{3}}{\mathrm{~A}_{3}}
$$


Therefore,

$$
\frac{\mathrm{w}_{1}}{\mathrm{w}}=\frac{\mathrm{A}_{1}}{\mathrm{~A}}, \frac{\mathrm{w}_{2}}{\mathrm{w}}=\frac{\mathrm{A}_{2}}{\mathrm{~A}} \text {, and } \frac{\mathrm{w}_{3}}{\mathrm{w}}=\frac{\mathrm{A}_{3}}{\mathrm{~A}} \text {. }
$$

Furthermore, the system design makes $w_{1} r_{1}=w_{2} r_{2}=w_{3} r_{3}$ since the pins were 120 degrees apart.

$$
\frac{\mathrm{w}_{1}}{1 / \mathrm{r}_{1}}=\frac{\mathrm{w}_{2}}{1 / \mathrm{r}_{2}}=\frac{\mathrm{w}_{3}}{1 / \mathrm{r}_{3}}=\frac{\mathrm{w}}{\mathrm{K}} \text {. }
$$

Therefore,

$$
\frac{\mathrm{w}_{1}}{\mathrm{w}}=\frac{\mathrm{K}}{\mathrm{r}_{1}}, \frac{\mathrm{w}_{2}}{\mathrm{w}}=\frac{\mathrm{K}}{\mathrm{r}_{2}} \text {, and } \frac{\mathrm{w}_{3}}{\mathrm{w}}=\frac{\mathrm{K}}{\mathrm{r}_{3}} \text {, }
$$

where $\mathrm{K}$ is a constant. Both the velocity and distance each pin rubbed relative to the rotating disc are proportional to the radius of that pin, $r_{i}$, from the center of the disk. Therefore, the coefficient of friction measured is a "weighted" average of each of the three pins. The "weighting" of the friction value from each pin is such that, for each pin, it is proportional to: (1) the fraction of total pin area, (2) the fraction of load carried, and (3) the inverse of the distance traveled per unit time. This weighted average value of the coefficient of friction appears to be more representative than individual values taken under very defined conditions.

b. Wear Rate Measurements

Pin and plate specimens were examined for wear, or evidence of material buildup and galling, after each sliding contact test. Before and after test, physical examination on individual pins included pin weight determined on a Sartorius Werke Model DP-2 Analytical Balance, hardness (taken as close to the wear surface as pratical) determined by means of a calibrated Wilson Rockwell Hardness Tester Model 3JR, and dimensional measurements using a calibrated Starrett No. 436 micrometer. The surface finish on the wear contact surface of the pins was taken before test and, where pratical, after test, using a Bendix 
Profilometer Type AD Model 12 with a G-Type Tracer, calibrated to a standard roughness specimen.

The plate specimen examination before and after test included ambient temperature hardness and profilorneter tracings. 


\section{TEST RESULTS}

The data obtained from this test prograrn are presented in this section in two parts: static contact results and sliding contact results. All the data in this section are presented in tabular form. The static contact data are presented in two tables based on whether or not the data had been previously published by LMEC. The first table (Table 8A), previously published in LMEC document NAA-SR-12446, "Static and Sliding Behavior of Materials in Sodium Environments at Elevated Temperatures, "by Freede, etal. (September 1967), is again reproduced here with the following modification: The initial static coefficients

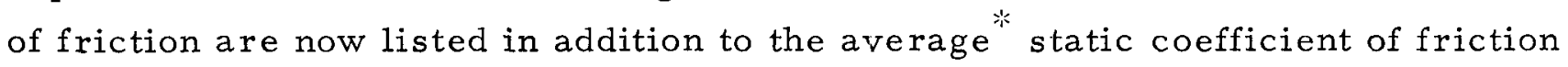
reading. All the values in Table $8 \mathrm{~B}$ represent new data. Sliding contact results from the previous LMEC work have been merged with the new data since no changes in data headings were made in utilizing the previously reported sliding contact data. These data are presented in two tables: for the liquid sodium environment (Table 9) and the sodium vapor environment (Table 10).

*Averaged from any readings taken on fresh surfaces after various exposure times. 
TABLE 8A

STATIC CONTACT RESULTS FROM $1200^{\circ} \mathrm{F}$ TESTS FIRST MATERIAL GROUP

\begin{tabular}{|c|c|c|c|c|c|c|c|c|c|}
\hline \multirow{2}{*}{\multicolumn{2}{|c|}{ Material Combinations }} & \multirow{4}{*}{$\begin{array}{c}\text { Pin } \\
\text { Contact } \\
\text { Area } \\
\left(\mathrm{cm}^{2} \times 10^{4}\right)\end{array}$} & \multirow{4}{*}{$\begin{array}{l}\text { Minimum } \\
\text { Pin } \\
\text { Surface } \\
\text { Pressure } \\
\left(\mathrm{kg} / \mathrm{cm}^{2}\right)\end{array}$} & \multirow{4}{*}{$\begin{array}{c}\text { Initial } \\
\text { Static } \\
\text { Friction } \\
\text { Coefficient } \\
\text { at } \\
\text { Temperature }\end{array}$} & \multirow{4}{*}{$\begin{array}{l}\text { Average } \\
\text { Static } \\
\text { Friction } \\
\text { Coefficient } \\
\text { After } \\
>700 \text { hrs } \\
\text { at } \\
\text { Temperature }\end{array}$} & \multicolumn{4}{|c|}{ Self.Weiding Coefficient $t$} \\
\hline & & & & & & \multicolumn{3}{|c|}{ Circulating Liquid Sodium } & \multirow{3}{*}{$\begin{array}{c}\text { Sodium } \\
\text { Vapor } \\
\text { Over } \\
\text { Cold-Trapped } \\
\text { Liquid } \mathrm{Na} \\
\text { After } 792 \mathrm{hr}\end{array}$} \\
\hline Plate & Pins & & & & & \multicolumn{2}{|c|}{$\begin{array}{l}\text { Cold-Tralped } \\
\left.1<30_{1} \text { pm } \mathrm{O}_{2}\right)\end{array}$} & \multirow{2}{*}{$\begin{array}{l}\begin{array}{c}\text { Hot -Trapped } \\
\left(<5 \mathrm{ppm} \mathrm{O} \mathrm{O}_{2}\right)\end{array} \\
\begin{array}{c}\text { After } \\
745 \mathrm{hr}\end{array}\end{array}$} & \\
\hline & & & & & & $\begin{array}{l}\text { After } \\
912 \mathrm{hr}\end{array}$ & $\begin{array}{l}\text { After } \\
1560 \mathrm{hr}\end{array}$ & & \\
\hline K-95 (WC) & $K \cdot 95$ & 27 & 2740 & 0.3 & 0.4 & 0.5 & 0.8 & 0.5 & 0.4 \\
\hline$K \cdot 95$ & K-162B & 14 & 5480 & 0.3 & 0.3 & 1.1 & 1.2 & 0.8 & 0.6 \\
\hline K.95 & AISI TI & 130 & 570 & 0.3 & 0.8 & 2.0 & 3.0 & 2.1 & 1.9 \\
\hline K.95 & AISI M1 & 115 & 650 & 0.3 & 0.8 & 2.4 & 2.7 & 3.1 & 2.1 \\
\hline K.95 & AISI M2 & 168 & 440 & 0.3 & 12 & 2.2 & 4.1 & 3.1 & 2.8 \\
\hline K-95 & AISI M3 Type 1 & 158 & 470 & 0.2 & 0.7 & 2.0 & 3.6 & 2.0 & 2.1 \\
\hline K.95 & Stellite $6 \mathrm{~B}$ & 52 & 1430 & 0.3 & 0.4 & 09 & 2.0 & 0.4 & 0.9 \\
\hline K.95 & Colmonoy 4 & 222 & 340 & 0.6 & 0.3 & 3.6 & 4.6 & 3.6 & 0.6 \\
\hline$K-95$ & Hasteliov C & 68 & 1000 & 0.3 & 0.4 & 1.3 & 1.4 & 1.2 & 1.5 \\
\hline $\mathrm{K} \cdot 162 \mathrm{~B}(\mathrm{TiC})$ & K $162 B$ & 23 & 3160 & 0.3 & 0.3 & 0.4 & 08 & 0.4 & 0.6 \\
\hline$K \cdot 162 B$ & AIS| T1 & 106 & 700 & 0.3 & 1.0 & 1.4 & 2.0 & 20 & 2.0 \\
\hline$K \cdot 162 B$ & AISI M1 & 120 & 620 & 0.3 & 1.0 & 0.5 & 1.4 & 1.5 & 1.4 \\
\hline$K-162 B$ & AlS $\mid M 2$ & 112 & 660 & 0.2 & 1.1 & 2.2 & 2.3 & 2.6 & 2.3 \\
\hline$K \cdot 162 B$ & AISI M3 Type 1 & 132 & 560 & 0.2 & 0.6 & 0.6 & 1.9 & 2.2 & 1.6 \\
\hline K-162B & Stellite $6 B$ & 160 & 460 & 0.4 & 0.9 & 1.3 & 2.3 & 1.6 & 2.0 \\
\hline$K \cdot 162 B$ & Colmonov 4 & 174 & 430 & 0.3 & 0.7 & 2.2 & 3.6 & 2.1 & 1.3 \\
\hline$K \cdot 162 B$ & Hastellov C & 120 & 620 & 0.3 & 0.8 & 1.0 & 24 & 2.1 & 0.9 \\
\hline$K \cdot 162 B$ & Molvbdenum & 83 & 890 & 0.3 & 0.7 & 0.6 & 1.8 & 1.5 & 1.0 \\
\hline AISIT TI & AISI T1 & 86 & 870 & 0.2 & 1.2 & 2.6 & 2.6 & 2.6 & 2.1 \\
\hline AISI T1 & AISI M1 & 129 & 580 & 0.2 & 1.1 & 1.7 & 2.4 & 2.0 & 2.1 \\
\hline AISI T1 & AISI M2 & 153 & 490 & 0.2 & 1.0 & 1.0 & 2.2 & 2.3 & 2.0 \\
\hline AISI T1 & AlsI M3 Type I & 92 & 810 & 0.3 & 1.2 & 2.0 & 2.7 & 2.2 & 1.5 \\
\hline AISI T1 & Stellite 68 & 85 & 870 & 0.2 & 1.1 & 0.6 & 2.6 & 2.0 & 2.0 \\
\hline AISI T1 & Colmonoy 4 & 151 & 490 & 0.2 & 1.1 & 3.0 & 5.8 & 1.8 & 1.6 \\
\hline AISI T 1 & Hastelloy C & 121 & 610 & 0.4 & 0.6 & 1.0 & 2.6 & 2.5 & 3.1 \\
\hline AISI M2 & AISI M2 & 108 & 690 & 0.3 & 1.1 & 1.9 & 3.1 & 3.1 & 2.5 \\
\hline AISI M2 & AISI M3 Type 1 & 143 & 520 & 0.2 & 1.2 & 2.5 & 3.1 & 2.8 & 2.7 \\
\hline AISI M2 & Stellite 68 & 134 & 560 & 0.2 & 1.1 & 0.6 & 2.2 & 2.1 & 2.3 \\
\hline AISI M2 & Colmonoy 4 & 160 & 460 & 0.2 & 0.7 & 2.5 & 4.9 & 1.8 & 1.7 \\
\hline AISI M2 & Hastelloy C & 85 & 880 & 0.2 & 0.9 & 1.8 & 2.7 & 2.4 & 2.0 \\
\hline AlsI M3 Type 1 & AISI M3 Trpe 1 & 149 & 500 & 0.3 & 1.1 & 2.2 & 23 & 2.0 & 2.0 \\
\hline AISI M3 Type 1 & Stellite $6 \mathrm{~B}$ & 104 & 720 & 0.2 & 1.0 & 2.7 & 3.1 & 2.4 & 2.6 \\
\hline AISI M3 Type 1 & Colmonoy 4 & 149 & 500 & 0.2 & 0.9 & 2.7 & 5.3 & 2.0 & 1.5 \\
\hline AISI M3 Type 1 & Hastelloy C & 96 & 770 & 0.3 & 1.0 & 2.1 & 3.5 & 2.4 & 2.2 \\
\hline Stellite $6 \mathrm{~B}$ & AISI M1 & 160 & 470 & 0.3 & 0.8 & 2.1 & 4.2 & 3.6 & 4.9 \\
\hline Stellite 68 & AISI M2 & 182 & 410 & 0.3 & 0.8 & 0.5 & 2.3 & 2.7 & 4.0 \\
\hline Stellite 68 & Moiybdenum & 77 & 970 & 0.4 & 0.4 & 1.0 & 1.6 & 1.4 & 1.3 \\
\hline Stellite $6 B$ & Steltite $6 B$ & 91 & 820 & 0.4 & 0.4 & 0.9 & 2.4 & 1.6 & 2.0 \\
\hline Stellite 68 & Colmonoy 4 & 182 & 410 & 0.3 & 0.6 & 2.2 & 3.6 & 2.4 & 1.4 \\
\hline Stellite 6B & Hastelloy $\mathrm{C}$ & 49 & 1510 & 0.2 & 0.5 & 0.4 & 1.7 & 1.7 & 1.0 \\
\hline Hastelloy C & AISI M3 Type 1 & 246 & 310 & 0.4 & 1.5 & 1.0 & 4.4 & 4.5 & 40 \\
\hline Hastelloy C & Hastehoy C & 160 & 630 & 0.5 & 0.4 & 1.6 & 2.0 & 2.0 & 1.4 \\
\hline Colmonoy 4 & Colmonor 4 & 165 & 450 & 0.3 & 0.5 & 3.4 & 4.5 & 3.6 & 1.6 \\
\hline Colmonor 4 & Hasteltoy C & 165 & 450 & 0.3 & 0.3 & 2.4 & 3.6 & 2.0 & 1.1 \\
\hline Molybdenum & Stellite $6 B$ & 70 & 1060 & 0.3 & 0.5 & 1.3 & 2.0 & 0.6 & 0.4 \\
\hline Molybdenum & Hastelloy C & 72 & 1040 & 0.3 & 0.3 & 2.3 & 1.9 & 1.0 & 0.4 \\
\hline Molybdenum & Molybdenum & 106 & 700 & 0.3 & 0.8 & 0.9 & 12 & 10 & 0.9 \\
\hline Tungsten & Tungsten & 79 & 940 & 0.2 & 0.5 & 0.8 & 1.0 & 07 & 0.6 \\
\hline Tungsten & Molybdenum & 137 & 540 & 0.3 & 0.4 & 0.6 & 0.6 & 0.6 & 0.6 \\
\hline
\end{tabular}

- Taken on fresh surface.

IStatic friction coefficient, measured in shear on pin-plate combinations that have been under contact pressure during exposture 
TABLE 8B

STATIC CONTACT RESULTS FROM $1200^{\circ} \mathrm{F}$ TESTS SECOND MATERIAL GROUP

\begin{tabular}{|c|c|c|c|c|c|c|c|c|c|}
\hline \multirow{2}{*}{\multicolumn{2}{|c|}{ Materiał Combinations }} & \multirow{4}{*}{$\begin{array}{c}P_{\mathrm{n}} \\
\text { Contact } \\
\text { Area } \\
\left(\mathrm{cm}^{2} \times 10^{4}\right)\end{array}$} & \multirow{4}{*}{$\begin{array}{l}\text { Minimum } \\
\text { Pin } \\
\text { Surface } \\
\text { Pressure } \\
1 \mathrm{~kg} / \mathrm{cm}^{2} \mid\end{array}$} & \multirow{4}{*}{$\begin{array}{c}\text { Imitial } \\
\text { Static } \\
\text { Friction } \\
\text { Coefficient } \\
\text { at } \\
\text { Temperature }\end{array}$} & \multirow{4}{*}{$\begin{array}{c}\text { Average } \\
\text { Stalic } \\
\text { Friction } \\
\text { Coefficient } \\
\text { After } \\
>700 \mathrm{hrs} \\
\text { at } \\
\text { Temperature. }\end{array}$} & \multicolumn{4}{|c|}{ Seif Weldmg Coefficent' } \\
\hline & & & & & & \multicolumn{3}{|c|}{ Corcuslating Lefunct Sortum } & \multirow{3}{*}{ 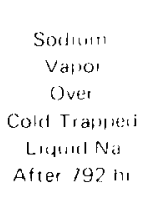 } \\
\hline \multirow[t]{2}{*}{ Plate } & \multirow[t]{2}{*}{ Pins } & & & & & \multicolumn{2}{|c|}{$\begin{array}{l}\text { Cold-Tramed } \\
\mathrm{K}^{2} 0 \mathrm{~mm} \mathrm{O}_{2}\end{array}$} & \multirow{2}{*}{$\begin{array}{l}\text { Hot Tramped } \\
\begin{array}{c}1<5 \text { prom } \mathrm{O}_{2} \text { ' } \\
\text { After } \\
768 \mathrm{hr}\end{array}\end{array}$} & \\
\hline & & & & & & $\begin{array}{l}\text { After } \\
720 \mathrm{hr}\end{array}$ & $\begin{array}{c}\text { After } \\
1560 \mathrm{hr}\end{array}$ & & \\
\hline$K \cdot 162 B$ & Star J & 71 & 1046 & 0.4 & 0.7 & 1.0 & 1.1 & 0.5 & 13 \\
\hline Colmonoy 75 & Colmonoy 6 & 142 & 524 & 0.2 & 0.4 & 0.4 & 09 & 1.0 & 04 \\
\hline Colmonoy 75 & Colmonoy 70 & 137 & 542 & 0.4 & 0.7 & 0.4 & 1.1 & 0.7 & 07 \\
\hline Colmonoy 75 & Stellite 1 & 91 & 812 & 0.6 & 0.7 & 1.2 & 1.3 & 15 & 1.2 \\
\hline Colmonoy 75 & Colmonor 5 & 103 & 721 & 0.5 & 0.6 & 1.3 & 1.1 & 1.6 & 0.9 \\
\hline Colmonor 75 & Stellite $6 \mathrm{H}$ & 107 & 694 & 0.5 & 0.8 & 1.1 & 1.5 & 13 & 0.9 \\
\hline Colmonoy 75 & Inconel 718 & 95 & 784 & 0.3 & 0.8 & 0.8 & 09 & 0.9 & 0.6 \\
\hline Colmonoy 75 & Tungsten & 62 & 1199 & 0.4 & 0.7 & 09 & 1.2 & 1.4 & 1.5 \\
\hline Colmonoy 75 & Haynes 273 & 83 & 894 & 0.3 & 0.8 & 1.4 & 1.3 & 1.2 & 0.9 \\
\hline Colmonoy 75 & Colmonoy 75 & 273 & 272 & 0.3 & 0.7 & 04 & 1.5 & 0.9 & 1.5 \\
\hline Colmonoy 6 & Colmonoy 70 & 159 & 467 & 0.3 & 0.8 & 07 & 0.7 & 0.8 & 0.6 \\
\hline Colmonor 6 & Stellite 1 & 81 & 921 & 0.4 & 0.7 & 07 & 1.3 & 1.3 & 1.0 \\
\hline Colmonoy 6 & Colmonoy 5 & 128 & 581 & 0.3 & 0.7 & 09 & 1.1 & 0.5 & 0.4 \\
\hline Colmonoy 6 & Stellite $6 \mathrm{H}$ & 131 & 569 & 0.7 & 0.7 & 09 & 1.0 & 0.7 & 0.4 \\
\hline Colmonoy 6 & Inconel 718 & 108 & 687 & 0.3 & 0.7 & 06 & 1.2 & 10 & 12 \\
\hline Colmonoy 6 & Tungsten & 52 & 1417 & 0.7 & 0.8 & 0.4 & 1.4 & 1.1 & 1.0 \\
\hline Colmonov 6 & Haynes 273 & 89 & 838 & 0.7 & 07 & 10 & 11 & 13 & 1.2 \\
\hline Colmonoy 6 & Colmonoy 6 & 206 & 359 & 0.6 & 0.6 & 0.8 & 0.8 & 0.8 & 0.4 \\
\hline Colmonoy 70 & Stellite 1 & 120 & 619 & 0.3 & 0.9 & 1.2 & 1.3 & 1.1 & 1.5 \\
\hline Colmonoy 70 & Coimonoy 5 & 302 & 246 & 0.9 & 0.5 & 0.9 & 1.1 & 09 & 0.5 \\
\hline Colmonoy 70 & Stellite $6 \mathrm{H}$ & 122 & 607 & 1.0 & 0.8 & 1.1 & 1.0 & 1.3 & 0.9 \\
\hline Colmonov 70 & inconel 718 & 112 & 660 & 0.4 & 0.8 & 1.0 & 1.0 & 0.8 & 1.1 \\
\hline Colmonov 70 & Tungsten & 109 & 681 & 0.3 & 09 & 0.9 & 1.1 & 0.7 & 1.1 \\
\hline Coimonov 70 & Haynes 273 & 177 & 420 & 0.7 & 0.6 & 0.9 & 1.3 & 1.2 & 1.2 \\
\hline Colmonoy 70 & Colmonoy 70 & 151 & 490 & 0.3 & 0.5 & 10 & 0.7 & 0.6 & 0.4 \\
\hline K.95 & Star J & 24 & 3082 & 0.4 & 0.4 & 0.4 & 0.9 & 0.9 & 0.4 \\
\hline Stellite 1 & Colmonor 5 & 116 & 641 & 0.3 & 0.6 & 0.6 & 1.3 & 0.3 & 0.7 \\
\hline Stellite 1 & Stellite $6 \mathrm{H}$ & 87 & 856 & 0.5 & 0.6 & 1.7 & 2.2 & 0.7 & 1.6 \\
\hline Stellite 1 & Inconel 718 & 77 & 962 & 0.6 & 0.6 & 0.9 & 1.2 & 0.4 & 0.5 \\
\hline Stellite 1 & Tungsten & 55 & 1324 & 0.5 & 0.7 & 1.1 & 1.2 & 0.4 & 0.6 \\
\hline Stellite 1 & Haynes 273 & 59 & 1261 & 0.6 & 07 & 2.3 & 2.0 & 0.5 & 0.7 \\
\hline Stellite 1 & Stellite 1 & 37 & 2018 & 0.4 & 0.6 & 1.0 & 1.1 & 0.4 & 0.8 \\
\hline Colmonoy 5 & Stelitte $6 \mathrm{H}$ & 19 & 394 & 0.5 & 1.1 & 0.9 & 1.7 & 0.8 & 1.5 \\
\hline Colmanoy 5 & Inconel 718 & 18 & 419 & 0.7 & 0.7 & 11 & 1.2 & 1.5 & 13 \\
\hline Colmonoy 5 & Tungsten & 89 & 836 & 0.3 & 0.6 & 0.6 & 1.0 & 1.2 & 1.1 \\
\hline Colmonoy 5 & Haynes 273 & 138 & 538 & 0.4 & 0.9 & 0.8 & 1.5 & 1.4 & 1.7 \\
\hline Colmonoy 5 & Colmonoy 5 & 474 & 156 & 0.8 & 0.7 & 1.0 & 1.3 & 0.7 & 0.4 \\
\hline Stellite $6 \mathrm{H}$ & Stellite $6 \mathrm{H}$ & 81 & 914 & 0.3 & 0.7 & 1.0 & 1.4 & 11 & 10 \\
\hline Stellite $6 \mathrm{H}$ & Inconel 718 & 47 & 1589 & 0.4 & 0.6 & 0.7 & 1.2 & 0.9 & 0.9 \\
\hline Stellite $6 \mathrm{H}$ & Tungsten & 99 & 752 & 0.5 & 0.7 & 1.3 & 1.2 & 07 & 0.6 \\
\hline Stellite $6 \mathrm{H}$ & Haynes 273 & 50 & 1486 & 0.4 & 0.6 & 1.1 & 1.3 & 0.4 & 0.5 \\
\hline Stellite 6H & TZM & 56 & 1330 & 0.5 & 08 & 1.2 & 1.3 & 1.2 & 0.7 \\
\hline Inconel 718 & Tungsten & 98 & 756 & 0.4 & 0.7 & 0.7 & 1.3 & 1.1 & 0.5 \\
\hline Inconel 718 & Haynes 273 & 72 & 1029 & 0.4 & 0.7 & 10 & 1.3 & 0.9 & 11 \\
\hline Inconel 718 & Inconel 718 & 46 & 1607 & 0.6 & 0.7 & 0.9 & 1.2 & 1.2 & 0.5 \\
\hline Tungsten & Haynes 273 & 92 & 805 & 0.5 & 0.9 & 21 & 2.1 & 0.6 & 1.5 \\
\hline Tungsten & $T Z M$ & 120 & 620 & 0.5 & 0.7 & 0.5 & 0.6 & 0.7 & 0.9 \\
\hline $17.4 \mathrm{PH}$ & $17.4 \mathrm{PH}$ & 150 & 494 & 0.6 & 1.0 & 20 & 2.0 & 0.6 & 2.0 \\
\hline $17-4 \mathrm{PH}$ & 304 SS & 125 & 594 & 0.3 & 1.0 & 1.4 & 2.0 & 1.5 & 2.6 \\
\hline $17.4 \mathrm{PH}$ & $316 \mathrm{SS}$ & 107 & 692 & 0.7 & 1.0 & 1.5 & 2.1 & 1.9 & 1.5 \\
\hline 304 SS & 304 SS & 92 & 805 & 0.7 & 12 & 1.4 & 1.5 & 2.0 & 1.6 \\
\hline 316 SS & $316 \mathrm{SS}$ & 86 & 866 & 0.6 & 09 & 1.2 & 1.6 & 1.1 & 0.7 \\
\hline Haynes 273 & Haynes 273 & 93 & 802 & 0.5 & 0.6 & 2.0 & 2.1 & 1.0 & 1.0 \\
\hline $\operatorname{Re} \times 49$ & Rex 49 & 105 & 709 & 0.8 & 1.0 & 20 & 1.8 & 1.2 & 2.4 \\
\hline
\end{tabular}

- Taken on fresh surface.

IStatic triction coefficient, measured in shear, on pen-plate combinatıons that have been under contact pressure during exposure 
TABLE 9

TEST DATA FROM SLIDING CONTACT TESTS IN LIQUID SODIUM

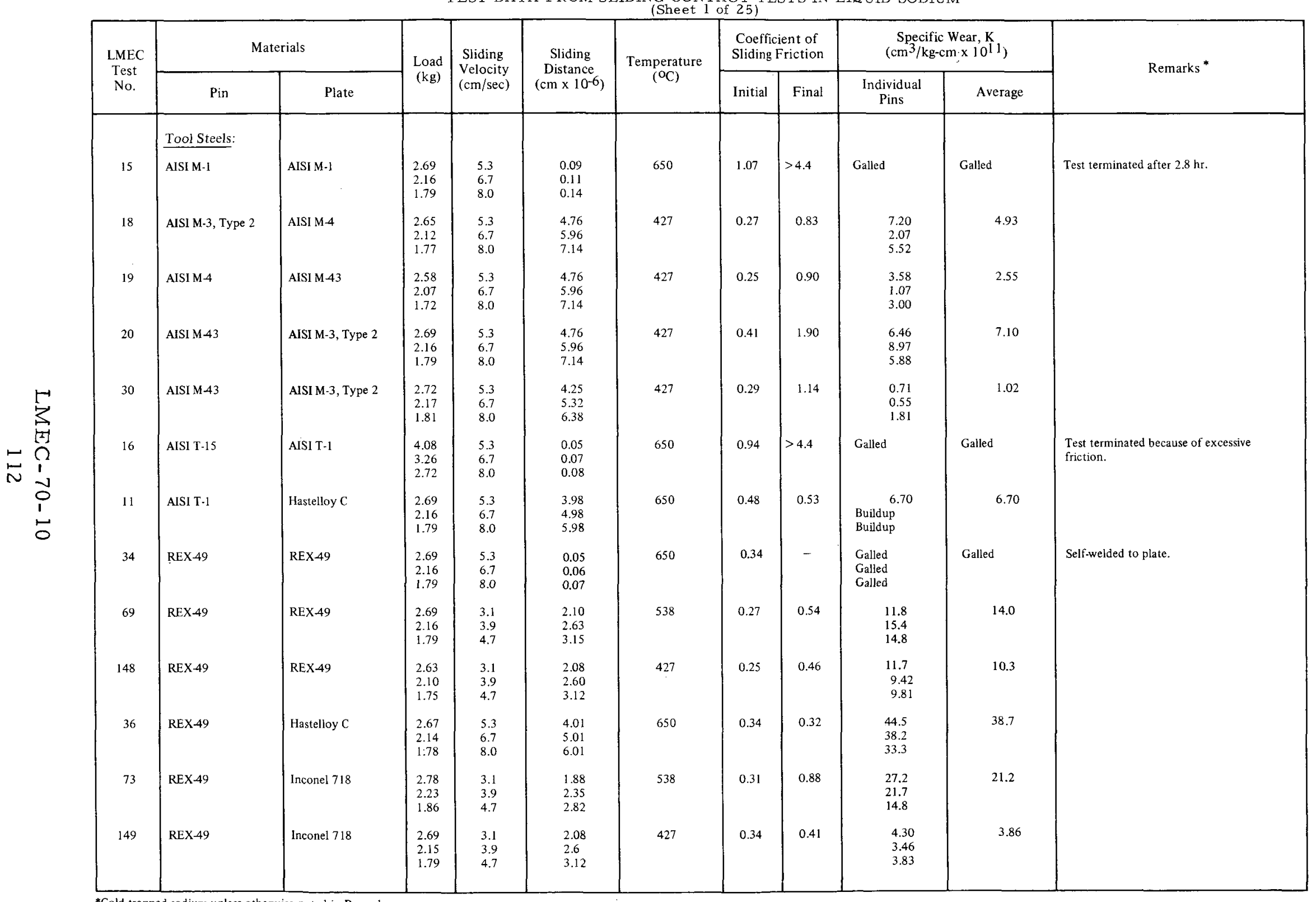

*Cold-trapped sodium unless otherwise noted in Remarks. 
TABLE 9

TEST DATA FROM SLIDING CONTACT TESTS IN LIQUID SODIUM

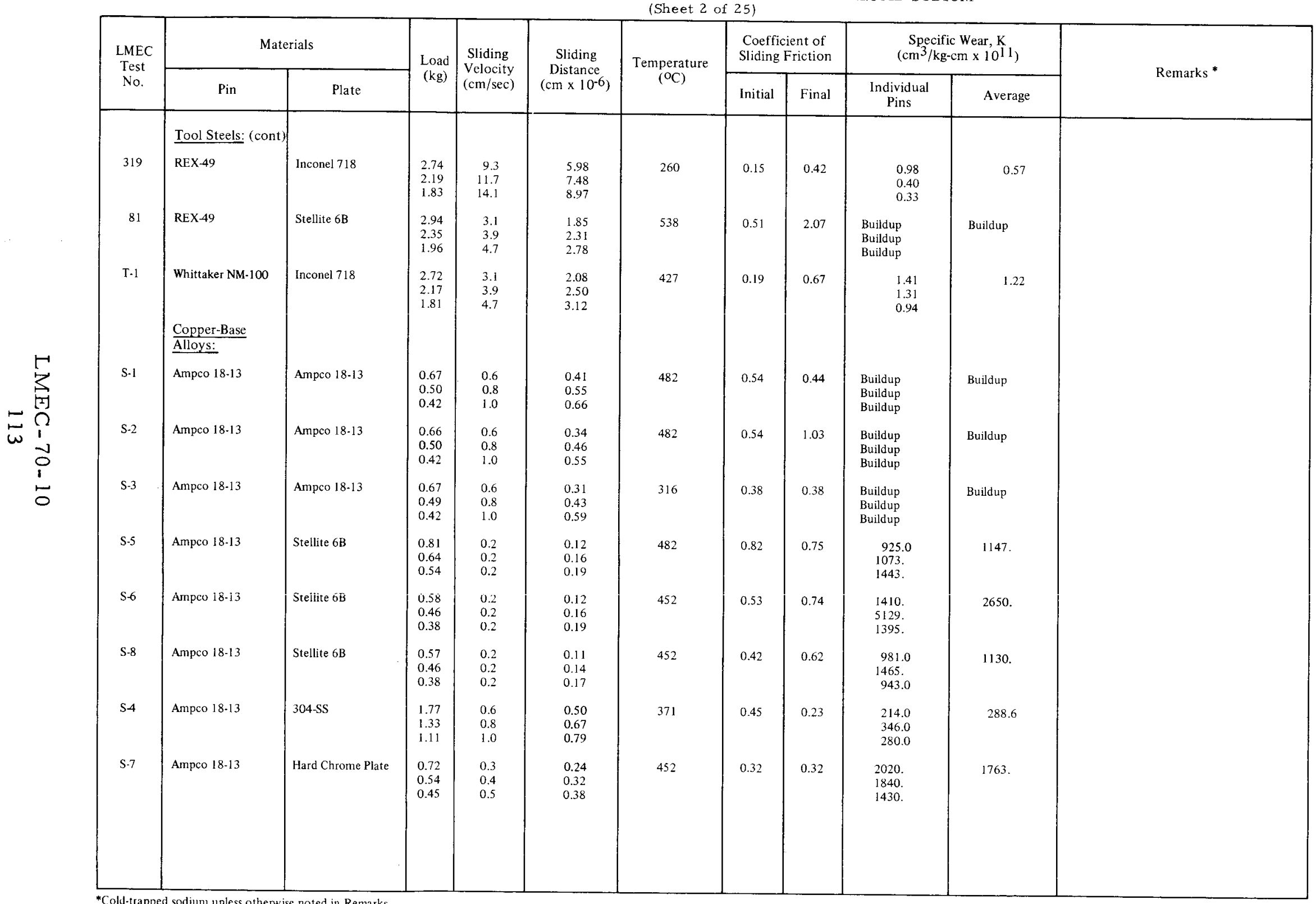


TABLE 9

TEST DATA FROM SLIDING CONTACT TESTS IN LIQUID SODIUM

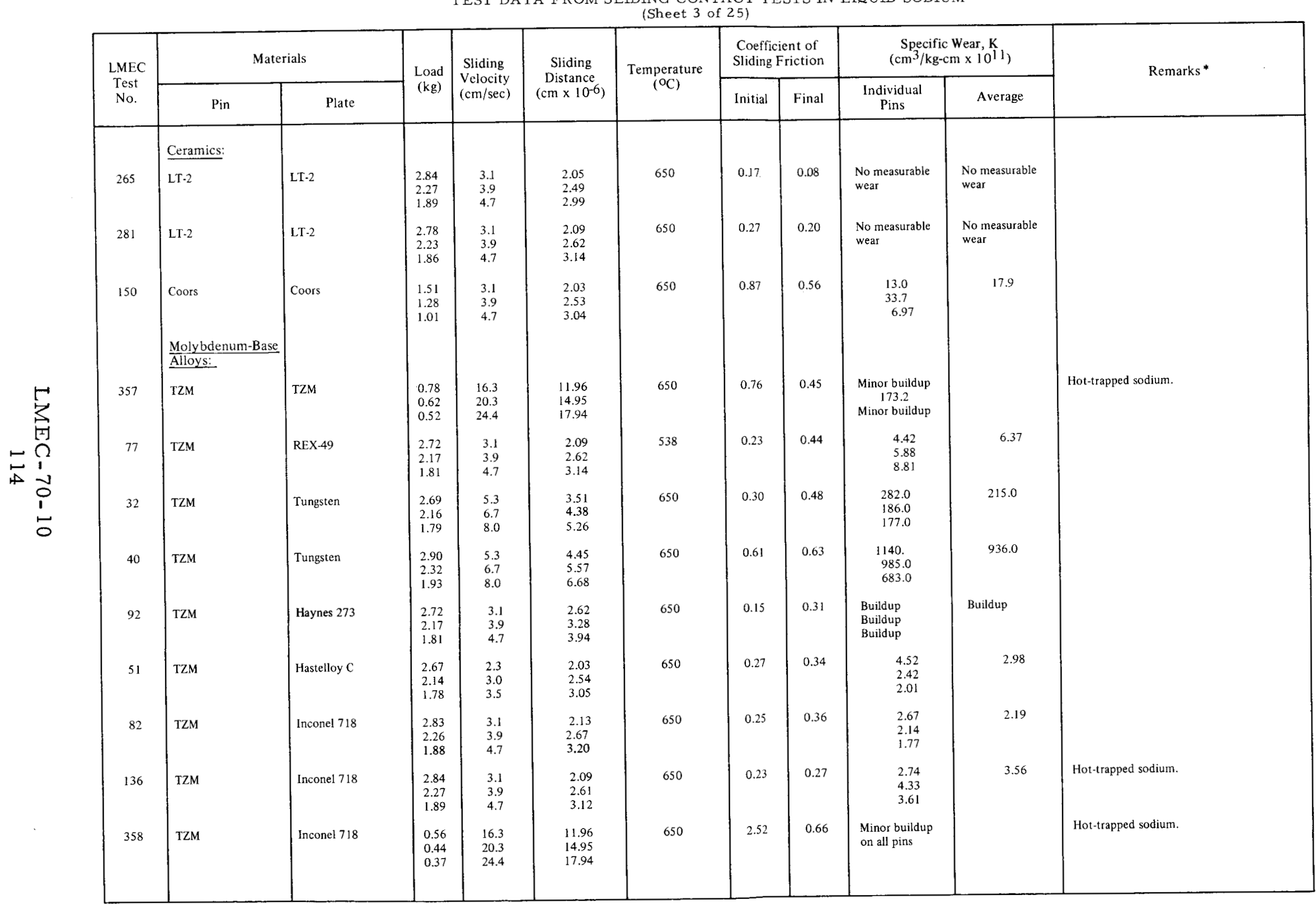

*Cold-trapped sodiunı unless otherwise noted in Remarks. 
TABIE 9

TEST DATA FROM SLIDING CONTACT TESTS IN LIQUID SODIUM

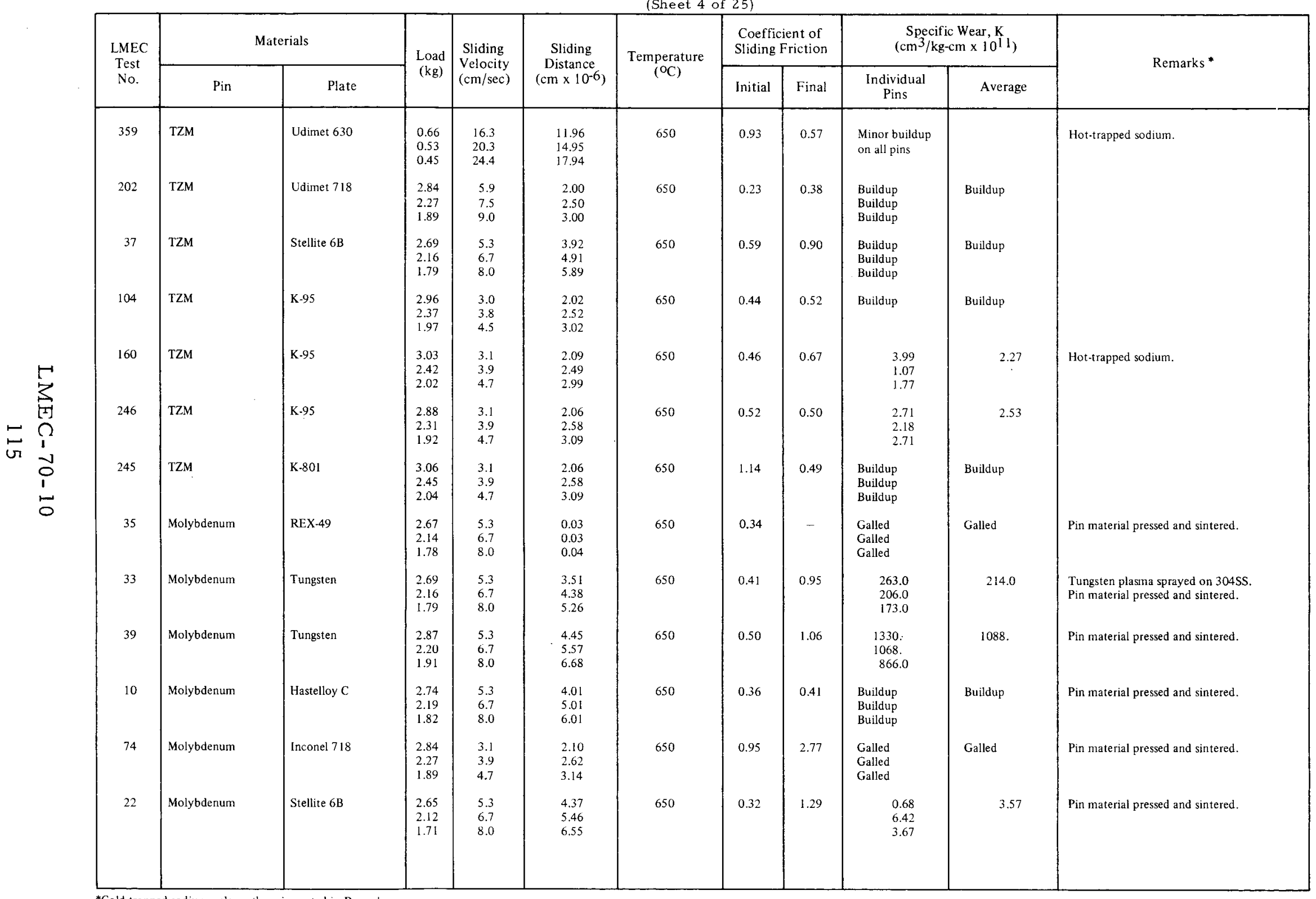


TABLE 9

TEST DATA FROM SLIDING CONTACT TESTS IN LIQUID SODIUM

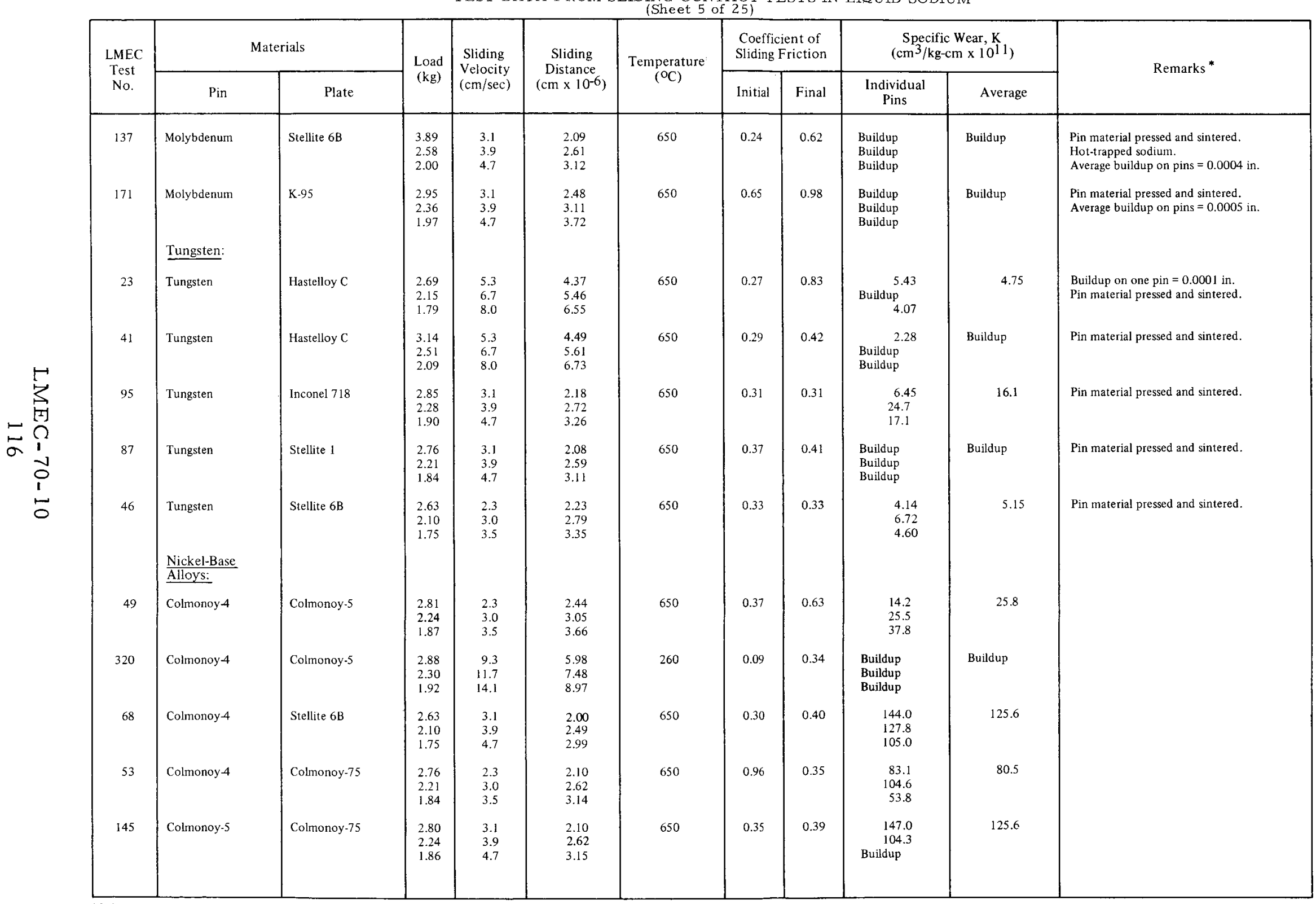

*Cold-trapped sodiunı unless otherwise noted in Remarks. 
TABLE 9

TEST DATA FROM SIIDING CONTACT TESTS IN LIRUID SODIUM

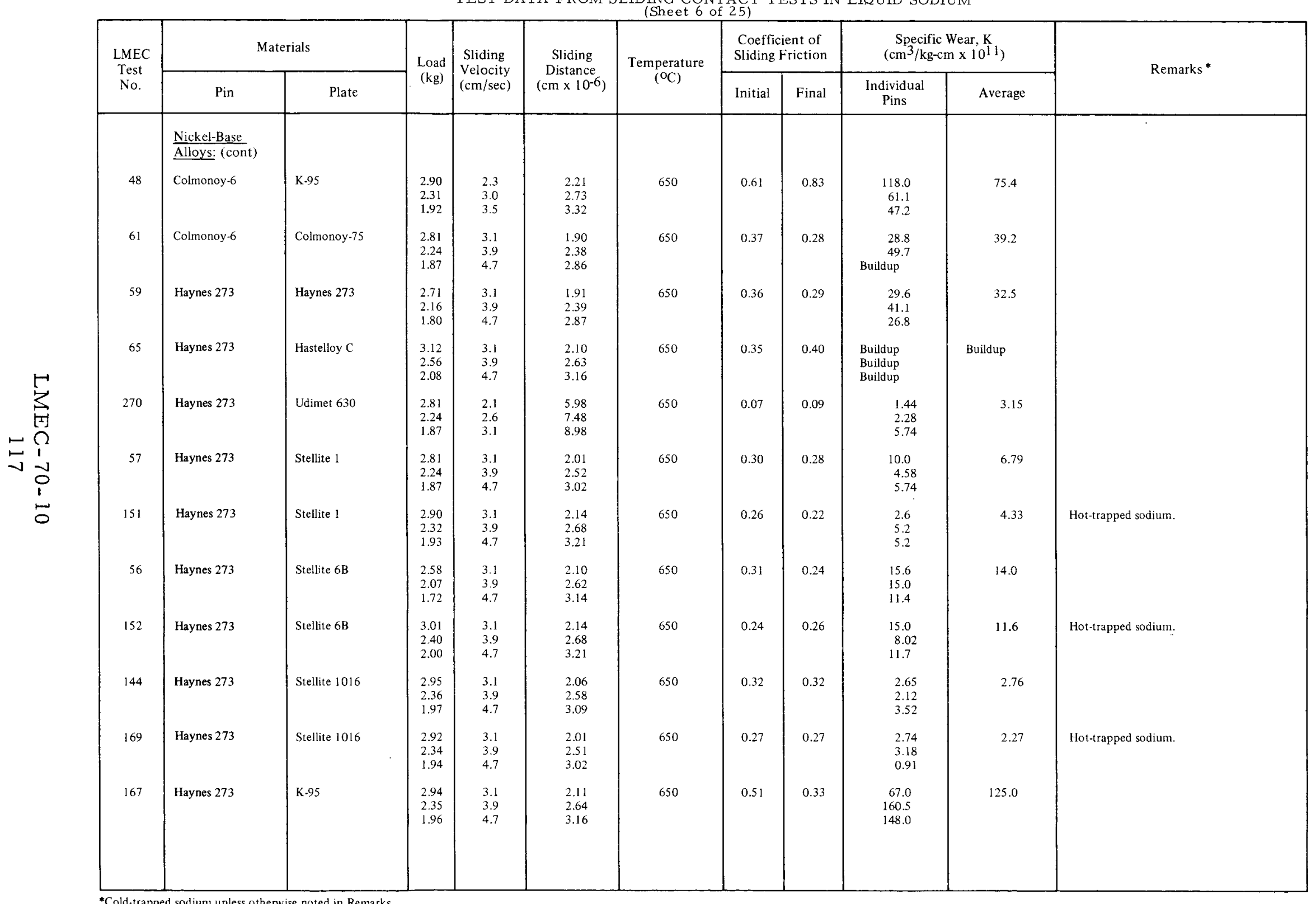


TABLE 9

TEST DATA FROM SLIDING CONTACT TESTS IN LIQUID SODIUM

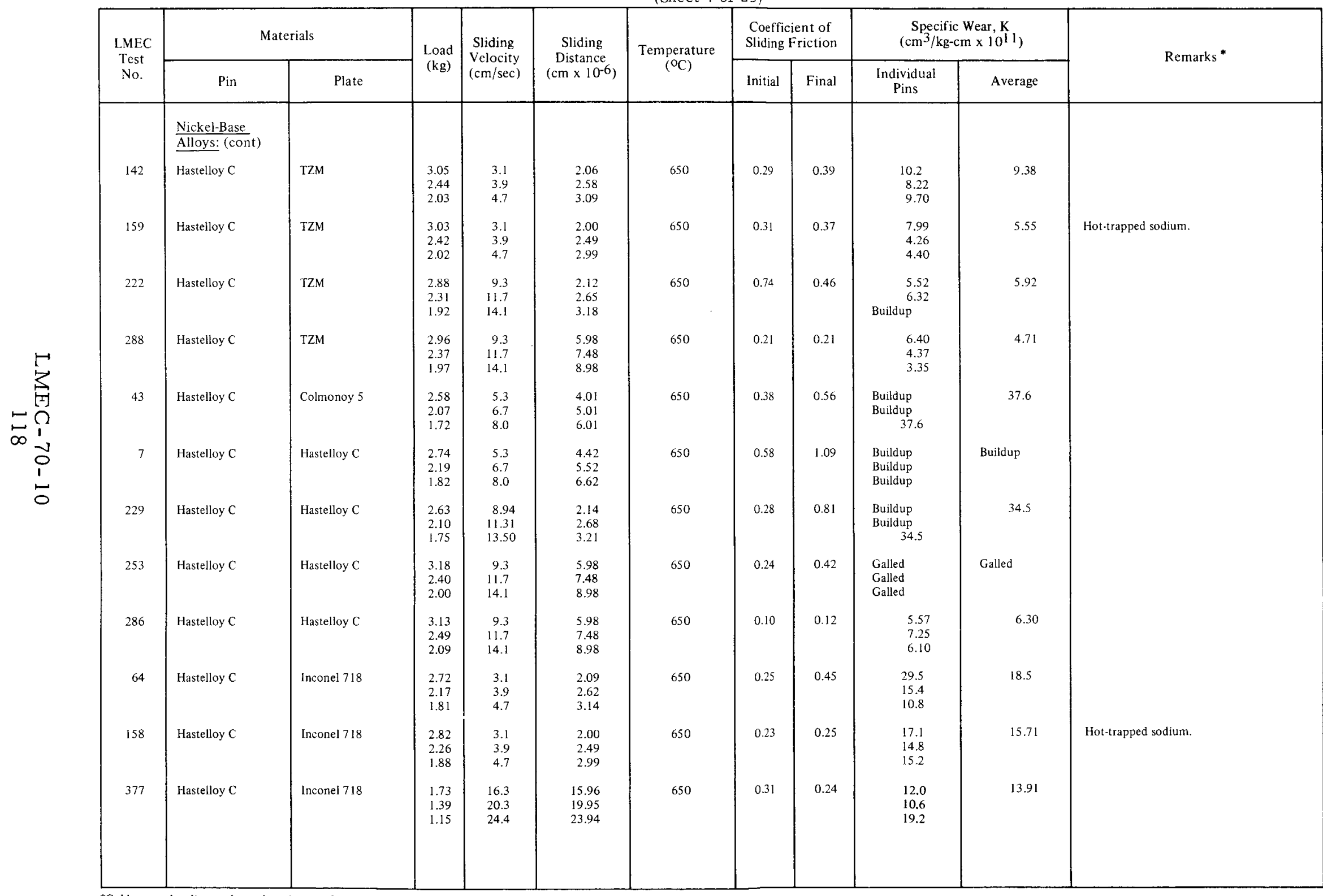

*Cold-trapped sodium unless otherwise noted in Remarks. 
TABLE 9

TEST DATA FROM SLIDING CONTACT TESTS IN LIQUID SODIUM

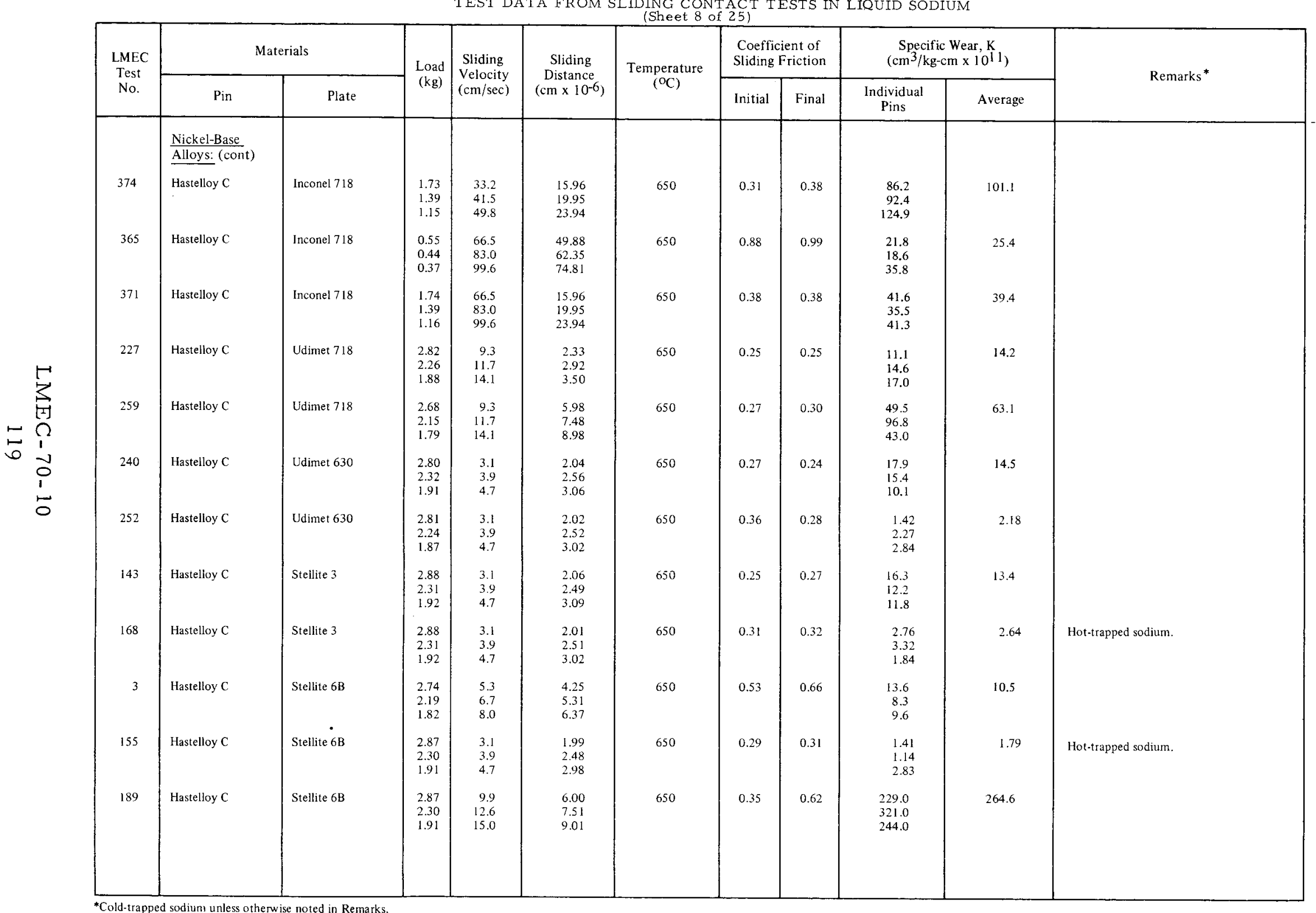


TABLE 9

TEST DATA FROM SLIDING CONTACT TESTS IN ILIQUID SODIUM

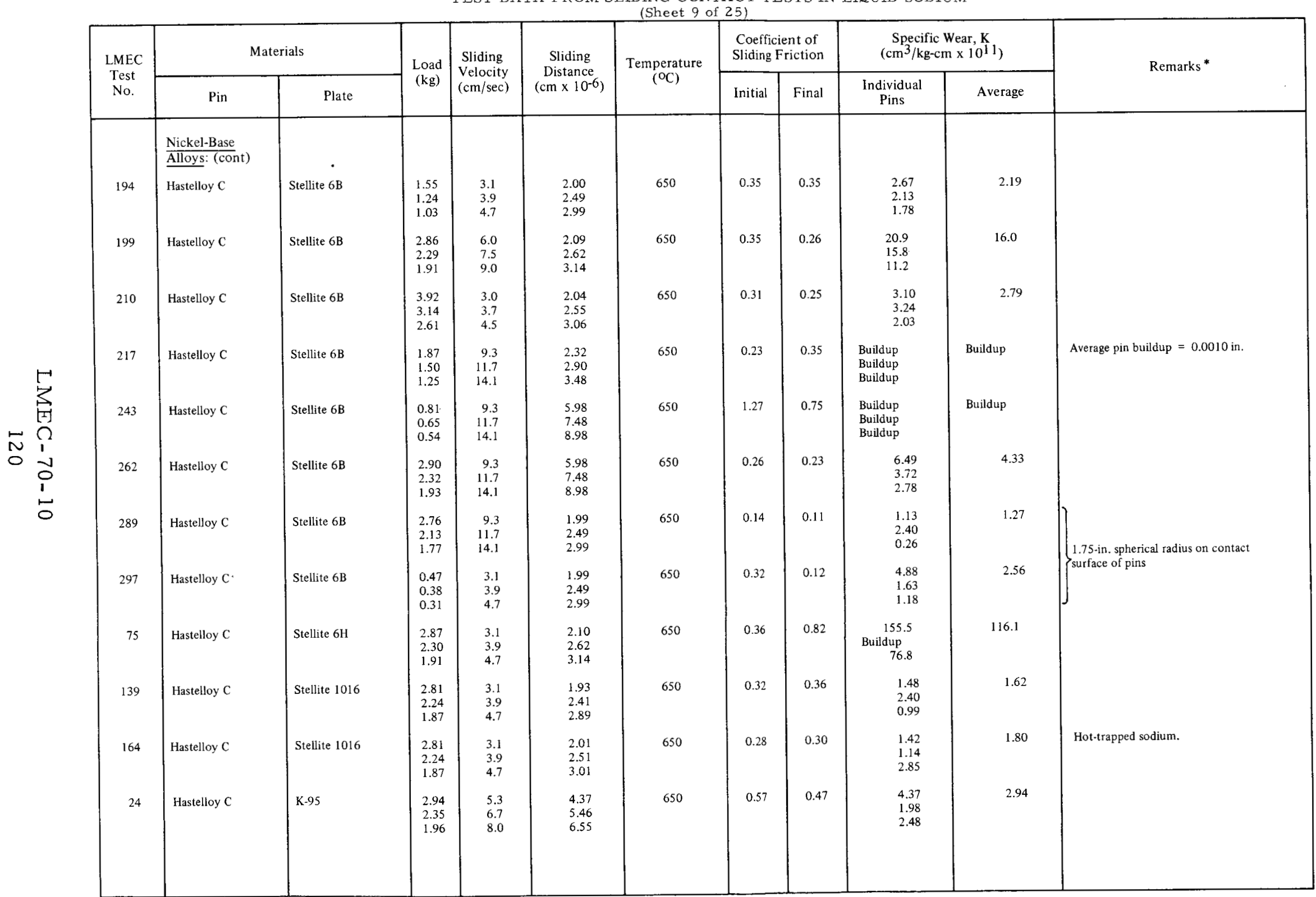

*Cold-trapped sodium unless otherwise noted in Remarks. 
TABLE 9

TEST DATA FROM SLIDING CONTACT TESTS IN LIQUID SODIUM

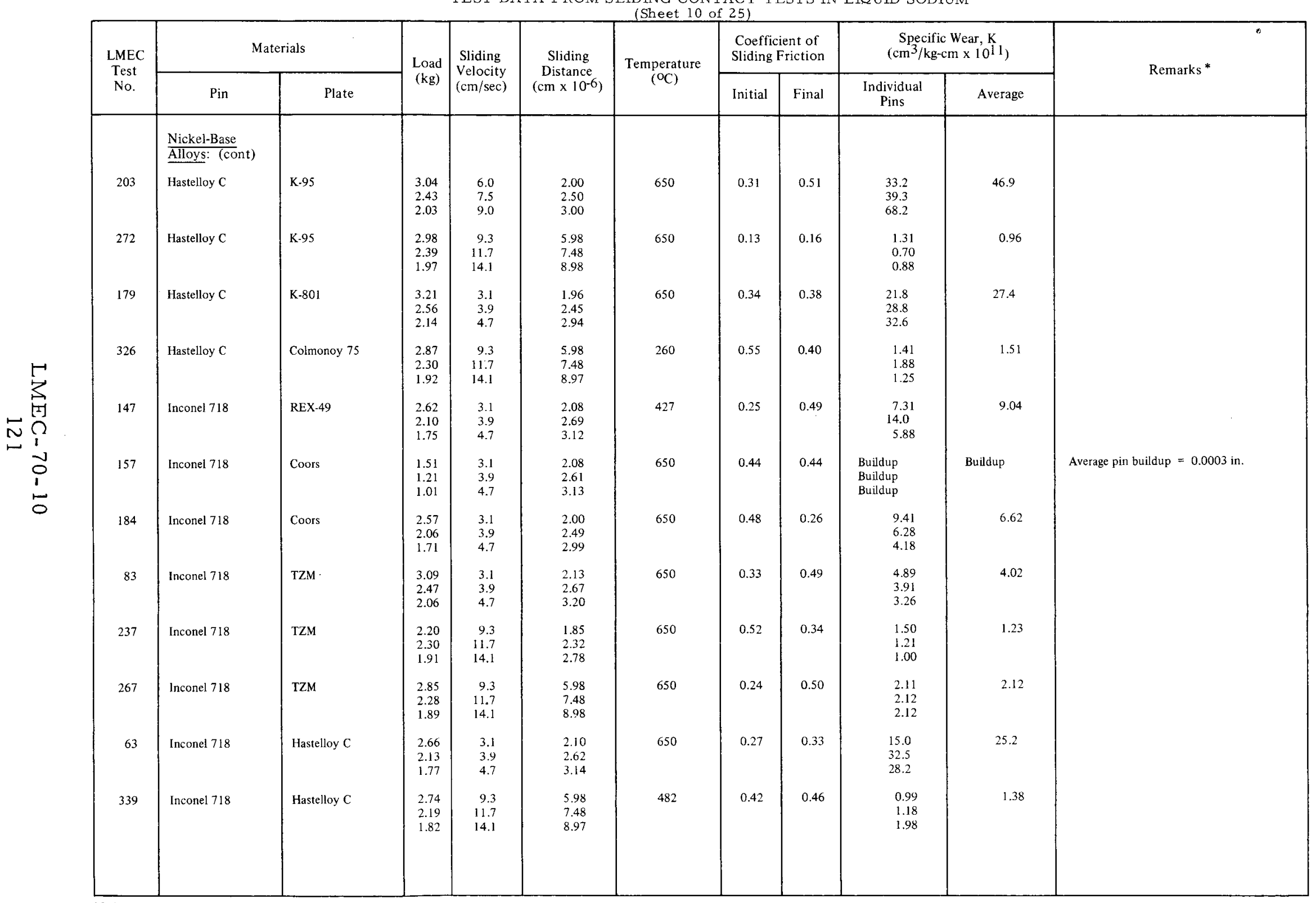

*Cold-trapped sodiurn unless otherwise noted in Remarks. 
TABLE 9

TEST DATA FROM SLIDING CONTACT TESTS IN LIQUID SODIUM

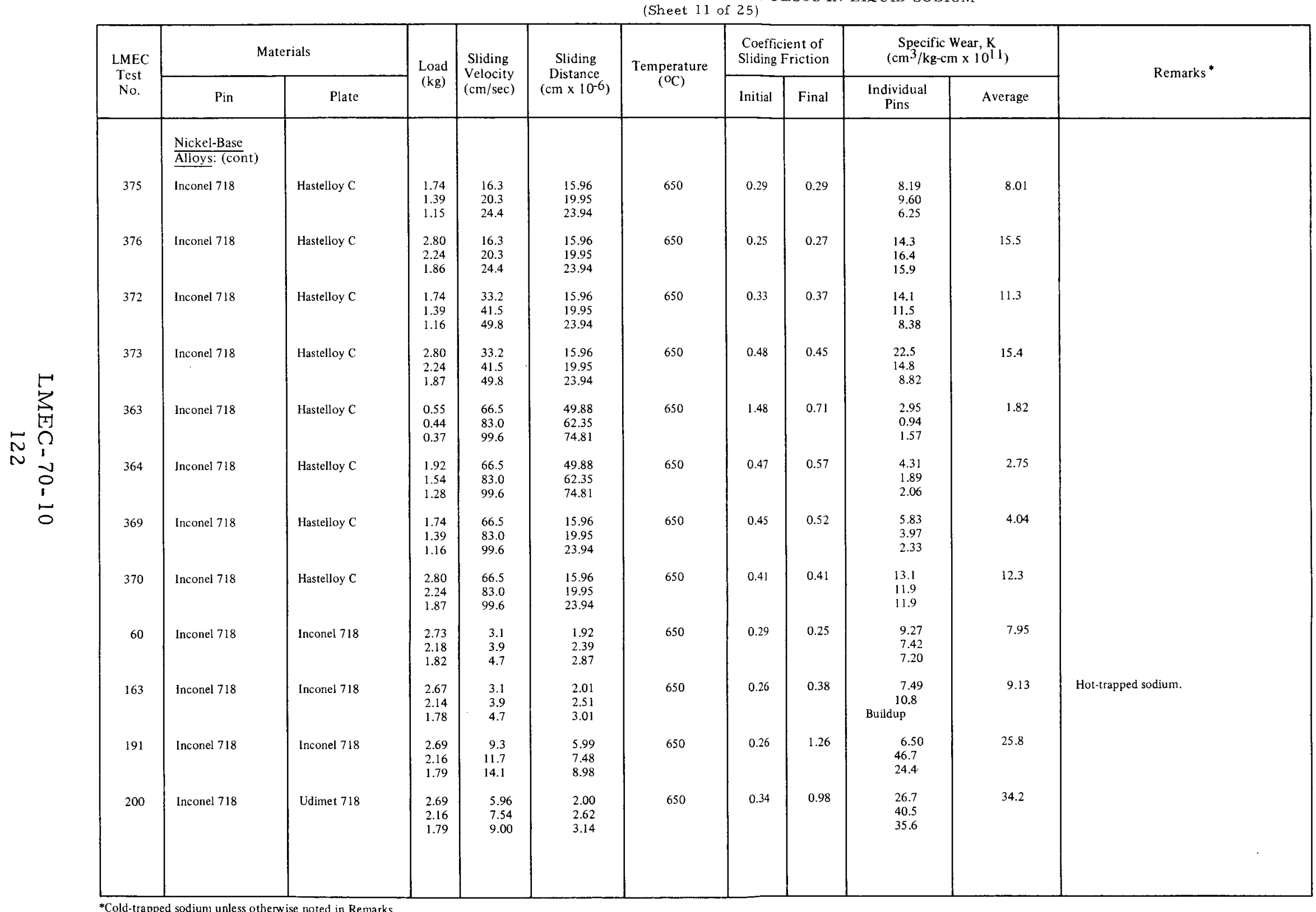

*Cold-trapped sodium unless otherwise noted in Remarks. 
TABLE 9

TEST DATA FROM SLIDING CONTACT TESTS IN IIQUID SODIUM

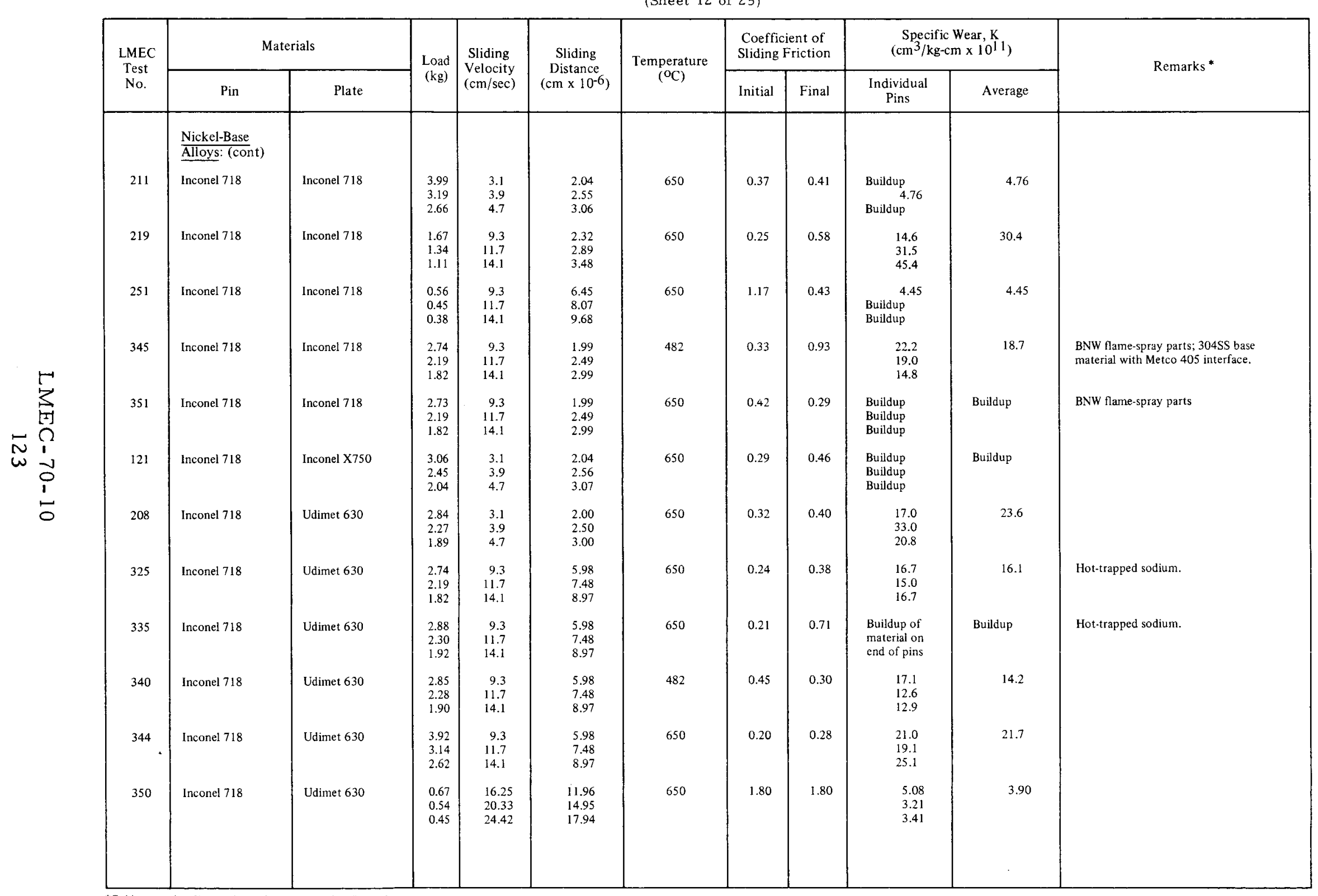

*Cold-trapped sodiun unless otherwise noted in Remarks. 
TABLE?

TEST DATA FROM SLIDING CONTACT TESTS IN LIQUID SODIUM

\begin{tabular}{|c|c|c|c|c|c|c|c|c|c|c|c|c|}
\hline & \multirow{2}{*}{$\begin{array}{l}\text { LMEC } \\
\text { Test } \\
\text { No. }\end{array}$} & \multicolumn{2}{|c|}{ Materials } & \multirow{2}{*}{$\begin{array}{c}\text { Load } \\
(\mathrm{kg})\end{array}$} & \multirow{2}{*}{$\begin{array}{l}\text { Sliding } \\
\text { Velocity } \\
(\mathrm{cm} / \mathrm{sec})\end{array}$} & \multirow{2}{*}{$\begin{array}{c}\text { Sliding } \\
\text { Distance } \\
\left(\mathrm{cm} \times 10^{-6}\right)\end{array}$} & \multirow{2}{*}{$\begin{array}{c}\text { Temperature } \\
\left({ }^{\circ} \mathrm{C}\right)\end{array}$} & \multicolumn{2}{|c|}{$\begin{array}{l}\text { Coefficient of } \\
\text { Sliding Friction }\end{array}$} & \multicolumn{2}{|c|}{$\begin{array}{c}\text { Specific Wear, } \mathrm{K} \\
\left(\mathrm{cm}^{3} / \mathrm{kg}-\mathrm{cm} \times 10^{11}\right)\end{array}$} & \multirow{2}{*}{ Remarks* } \\
\hline & & Pin & Plate & & & & & Initial & Final & $\begin{array}{l}\text { Individual } \\
\text { Pins }\end{array}$ & Average & \\
\hline \multirow{13}{*}{ 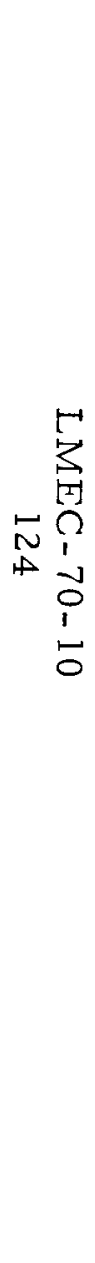 } & & $\frac{\text { Nickel-Base }}{\text { Alloys: (cont) }}$ & & & & & & & & & & \\
\hline & 356 & Inconel 718 & Udimet 630 & $\begin{array}{l}2.73 \\
2.18 \\
1.82\end{array}$ & $\begin{array}{l}16.3 \\
20.3 \\
24.4\end{array}$ & $\begin{array}{l}11.96 \\
14.95 \\
17.94\end{array}$ & 650 & 0.28 & 0.62 & $\begin{array}{l}17.2 \\
14.7 \\
13.2\end{array}$ & 15.0 & Hot-trapped sodium. \\
\hline & 362 & Inconel 718 & Udimet 630 & $\begin{array}{l}0.67 \\
0.54 \\
0.44\end{array}$ & $\begin{array}{l}66.5 \\
83.0 \\
99.6\end{array}$ & $\begin{array}{l}47.94 \\
59.87 \\
71.78\end{array}$ & 650 & 0.59 & 0.95 & $\begin{array}{l}16.7 \\
11.5 \\
23.9\end{array}$ & 17.4 & Hot-trapped sodium. \\
\hline & 368 & Inconel 718 & Udimet 630 & $\begin{array}{l}1.85 \\
1.48 \\
1.24\end{array}$ & $\begin{array}{l}66.5 \\
83.0 \\
99.6\end{array}$ & $\begin{array}{l}15.96 \\
19.95 \\
23.94\end{array}$ & 650 & 0.67 & 0.41 & $\begin{array}{r}109.1 \\
81.6 \\
129.9\end{array}$ & 106.9 & \\
\hline & 72 & Inconel 718 & Stellite $6 \mathrm{~B}$ & $\begin{array}{l}3.05 \\
2.44\end{array}$ & $\begin{array}{l}3.1 \\
3.9\end{array}$ & $\begin{array}{l}1.81 \\
2.26 \\
2.71\end{array}$ & 650 & 0.81 & 0.26 & $\begin{array}{l}2.72 \\
4.85\end{array}$ & 3.87 & \\
\hline & 225 & Inconel 718 & Stellite 6B & $\begin{array}{l}2.98 \\
2.39 \\
1.99\end{array}$ & $\begin{array}{r}9.3 \\
11.7 \\
14.1\end{array}$ & $\begin{array}{l}2.33 \\
2.92 \\
3.50\end{array}$ & 650 & 0.33 & 0.29 & $\begin{array}{l}4.61 \\
5.53 \\
2.31\end{array}$ & 4.15 & \\
\hline & 258 & Inconel 718 & Stellite $6 \mathrm{~B}$ & $\begin{array}{l}2.73 \\
2.18 \\
1.82\end{array}$ & $\begin{array}{r}9.3 \\
11.7 \\
14.1\end{array}$ & $\begin{array}{l}6.04 \\
7.55 \\
9.06\end{array}$ & 650 & 0.37 & 0.34 & $\begin{array}{l}2.93 \\
3.92 \\
1.86\end{array}$ & 3.90 & \\
\hline & 93 & Inconel 718 & Stellite $6 \mathrm{H}$ & $\begin{array}{l}2.72 \\
2.17 \\
1.81\end{array}$ & $\begin{array}{l}3.1 \\
3.9 \\
4.7\end{array}$ & $\begin{array}{l}2.62 \\
3.28 \\
3.94\end{array}$ & 650 & 0.15 & 0.31 & $\begin{array}{l}4.58 \\
2.75 \\
3.07\end{array}$ & 3.46 & \\
\hline & 347 & Inconel 718 & Stellite 1016 & $\begin{array}{l}2.69 \\
2.15 \\
1.79\end{array}$ & $\begin{array}{r}9.3 \\
11.7 \\
14.1\end{array}$ & $\begin{array}{l}1.90 \\
2.49 \\
2.99\end{array}$ & 482 & 0.27 & 0.40 & $\begin{array}{l}39.2 \\
41.0 \\
50.2\end{array}$ & 43.4 & BNW flame-spray parts. \\
\hline & 353 & Inconel 718 & Stellite 1016 & $\begin{array}{l}2.69 \\
2.15 \\
1.79\end{array}$ & $\begin{array}{r}9.3 \\
11.7 \\
14.1\end{array}$ & $\begin{array}{l}1.99 \\
2.49 \\
2.99\end{array}$ & 650 & 0.34 & 0.30 & $\begin{array}{l}\text { Buildup of } \\
\text { material on } \\
\text { end of pins }\end{array}$ & Buildup & BNW flame-spray parts. \\
\hline & 66 & Inconel 718 & K-95 & $\begin{array}{l}2.92 \\
2.33 \\
1.94\end{array}$ & $\begin{array}{l}0.9 \\
1.2 \\
1.4\end{array}$ & $\begin{array}{l}0.40 \\
0.51 \\
0.61\end{array}$ & 650 & 0.49 & 1.50 & $\begin{array}{l}\text { No measurable } \\
\text { wear }\end{array}$ & $\begin{array}{l}\text { No measurable } \\
\text { wear }\end{array}$ & \\
\hline & 70 & Inconel 718 & K-95 & $\begin{array}{l}2.92 \\
2.33 \\
1.94\end{array}$ & $\begin{array}{l}3.1 \\
3.9 \\
4.7\end{array}$ & $\begin{array}{l}2.21 \\
2.77 \\
3.32\end{array}$ & 650 & 0.49 & 1.50 & $\begin{array}{l}3.75 \\
2.01 \\
2.52\end{array}$ & 2.76 & Continuation of LMEC Test No. 66 . \\
\hline & 176 & Inconel 718 & K-95 & $\begin{array}{l}2.98 \\
2.39 \\
1.99\end{array}$ & $\begin{array}{l}3.1 \\
3.9 \\
4.7\end{array}$ & $\begin{array}{l}2.22 \\
2.78 \\
3.33\end{array}$ & 650 & 0.45 & 0.43 & $\begin{array}{c}4.87 \\
18.5 \\
78.6\end{array}$ & 34.0 & \\
\hline
\end{tabular}

${ }^{*}$ Cold:trapped sodium unless otherwise noted in Remarks. 
TABLE 9

TEST DATA FROM SLIDING CONTACT TESTS IN LIQUID SODIUM

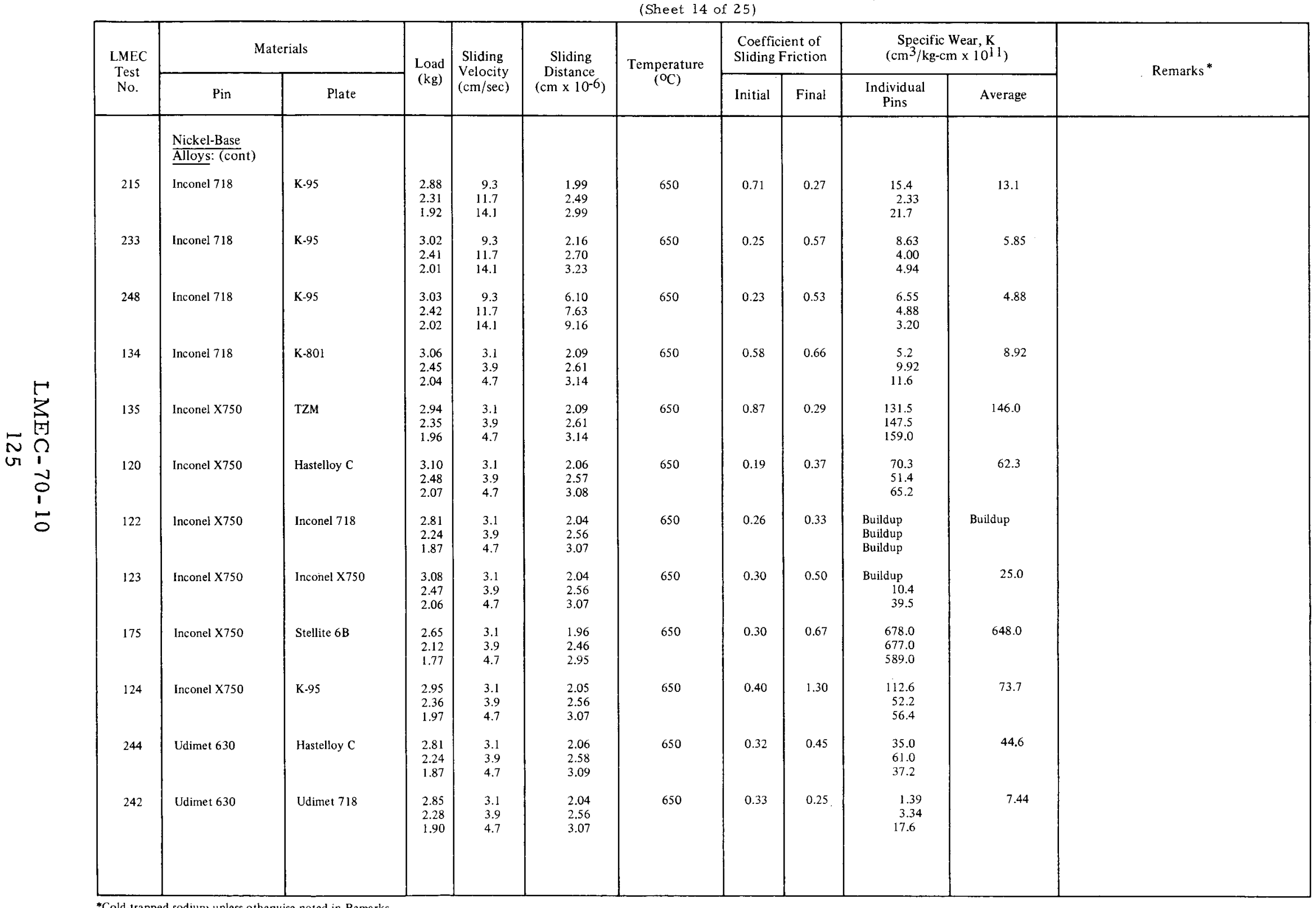


TABLE 9

TEST DATA FROM SLIDING CONTACT TESTS IN LIQUID SODIUM

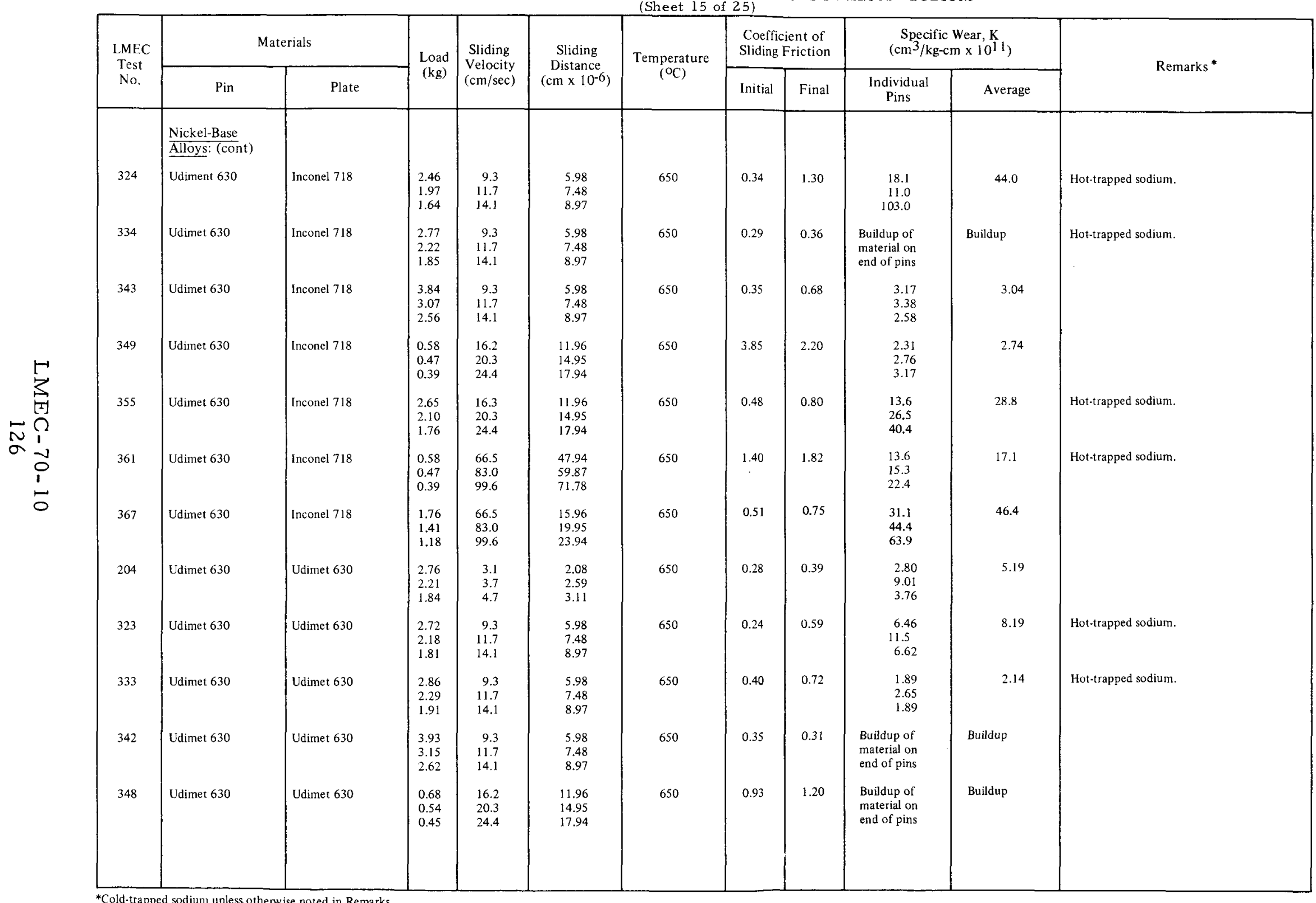


TABLE 9

TEST DATA FROM SLIDING CONTACT TESTS IN LIQUID SODIUM

\begin{tabular}{|c|c|c|c|c|c|c|c|c|c|c|c|c|}
\hline & \multirow{2}{*}{$\begin{array}{l}\text { LMEC } \\
\text { Test } \\
\text { No. }\end{array}$} & \multicolumn{2}{|c|}{ Materials } & \multirow{2}{*}{$\begin{array}{l}\text { Load } \\
(\mathrm{kg})\end{array}$} & \multirow{2}{*}{$\begin{array}{l}\text { Sliding } \\
\text { Velocity } \\
(\mathrm{cm} / \mathrm{sec})\end{array}$} & \multirow{2}{*}{$\begin{array}{c}\text { Sliding } \\
\text { Distance } \\
\left(\mathrm{cm} \times 10^{-6}\right)\end{array}$} & \multirow{2}{*}{$\begin{array}{l}\text { Temperature } \\
\left({ }^{\circ} \mathrm{C}\right)\end{array}$} & \multicolumn{2}{|c|}{$\begin{array}{l}\text { Coefficient of } \\
\text { Sliding Friction }\end{array}$} & \multicolumn{2}{|c|}{$\begin{array}{c}\text { Specific Wear, } K \\
\left(\mathrm{~cm}^{3} / \mathrm{kg}-\mathrm{cm} \times 10^{11}\right)\end{array}$} & \multirow{2}{*}{ Remarks ${ }^{*}$} \\
\hline & & Pin & Plate & & & & & Initial & Final & $\begin{array}{l}\text { Individual } \\
\text { Pins }\end{array}$ & Average & \\
\hline \multirow{15}{*}{ 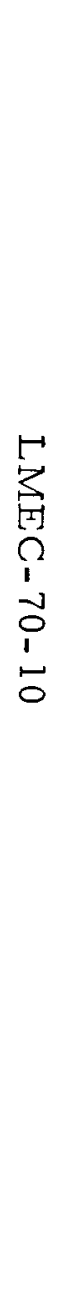 } & & $\begin{array}{l}\text { Nickel-Base } \\
\text { Alloys: (cont) }\end{array}$ & & & & & & & & & & \multirow{9}{*}{$\begin{array}{l}\text { Hot-trapped sodium } \\
\text { Hot-trapped sodium. } \\
\text { Average buildup on end of pins = } \\
0.0007 \text { in. }\end{array}$} \\
\hline & 354 & Udimet 630 & Udimet 630 & $\begin{array}{l}2.74 \\
2.19 \\
1.82\end{array}$ & $\begin{array}{l}16.3 \\
20.3 \\
24.4\end{array}$ & $\begin{array}{l}11.96 \\
14.95 \\
17.94\end{array}$ & 650 & 0.30 & 0.42 & $\begin{array}{l}3.47 \\
4.16 \\
2.81\end{array}$ & 3.48 & \\
\hline & 360 & Udimet 630 & Udimet 630 & $\begin{array}{l}0.68 \\
0.54 \\
0.45\end{array}$ & $\begin{array}{l}66.5 \\
83.0 \\
99.6\end{array}$ & $\begin{array}{l}47.94 \\
59.87 \\
71.78\end{array}$ & 650 & 1.32 & 1.05 & $\begin{array}{l}13.4 \\
27.5 \\
15.1\end{array}$ & 18.7 & \\
\hline & 366 & Udimet 630 & Udimet 630 & $\begin{array}{l}1.86 \\
1.49 \\
1.24\end{array}$ & $\begin{array}{l}66.5 \\
83.0 \\
99.6\end{array}$ & $\begin{array}{l}15.96 \\
19.95 \\
23.94\end{array}$ & 650 & 0.37 & 1.55 & $\begin{array}{r}86.9 \\
112.4 \\
130.4\end{array}$ & 109.9 & \\
\hline & 205 & Udimet 630 & Stellite 6B & $\begin{array}{l}2.85 \\
2.28\end{array}$ & $\begin{array}{l}3.1 \\
3.9 \\
47\end{array}$ & $\begin{array}{l}2.08 \\
2.59\end{array}$ & 650 & 0.24 & 0.41 & $\begin{array}{l}9.50 \\
6.58\end{array}$ & 7.49 & \\
\hline & & & & 1.99 & 4.1 & 3.11 & & & & 0.40 & & \\
\hline & 341 & Udimet 630 & Stellite 6B & $\begin{array}{l}3.00 \\
2.40 \\
2.00\end{array}$ & $\begin{array}{r}9.3 \\
11.7 \\
14.1\end{array}$ & $\begin{array}{l}5.98 \\
7.48 \\
8.97\end{array}$ & 650 & 0.58 & 0.48 & $\begin{array}{l}1.35 \\
1.44 \\
0.62\end{array}$ & 1.13 & \\
\hline & 206 & Udimet 630 & K.95 & $\begin{array}{l}2.90 \\
2.32 \\
1.93\end{array}$ & $\begin{array}{l}3.1 \\
3.9 \\
4.7\end{array}$ & $\begin{array}{l}2.08 \\
2.59 \\
3.11\end{array}$ & 650 & 0.37 & 0.99 & $\begin{array}{l}2.67 \\
4.30 \\
9.88\end{array}$ & 5.61 & \\
\hline & 220 & Udimet 630 & K-801 & $\begin{array}{l}3.14 \\
2.51 \\
2.09\end{array}$ & $\begin{array}{l}3.1 \\
3.9 \\
4.7\end{array}$ & $\begin{array}{l}2.00 \\
2.49 \\
2.99\end{array}$ & 650 & 0.27 & 0.63 & $\begin{array}{l}\text { Buildup } \\
\text { Buildup } \\
\text { Buildup }\end{array}$ & Buildup & \\
\hline & & Cobalt-Base Alloys & & & & & & & & & & \\
\hline & 89 & $\operatorname{Star} J$ & Molybdenum & $\begin{array}{l}3.09 \\
2.39 \\
1.99\end{array}$ & $\begin{array}{l}3.1 \\
3.9 \\
4.7\end{array}$ & $\begin{array}{l}2.10 \\
2.62 \\
3.14\end{array}$ & 650 & 0.94 & 0.66 & $\begin{array}{l}1.35 \\
2.15 \\
6.31\end{array}$ & 3.27 & \\
\hline & 96 & Star $J$ & Tungsten & $\begin{array}{l}3.02 \\
2.42 \\
2.02\end{array}$ & $\begin{array}{l}3.1 \\
3.9 \\
4.7\end{array}$ & $\begin{array}{l}2.18 \\
2.72 \\
3.26\end{array}$ & 650 & 0.61 & 0.41 & $\begin{array}{l}4.87 \\
1.94 \\
1.62\end{array}$ & 2.81 & \\
\hline & 80 & Star $\mathbf{J}$ & Hastelloy $\mathrm{C}$ & $\begin{array}{l}2.85 \\
2.28 \\
1.90\end{array}$ & $\begin{array}{l}3.1 \\
3.9 \\
4.7\end{array}$ & $\begin{array}{l}1.94 \\
2.42 \\
2.90\end{array}$ & 650 & 0.28 & 0.30 & $\begin{array}{l}1.18 \\
1.17 \\
0.87\end{array}$ & 1.07 & \\
\hline & 223 & Star J & Hastelloy C & $\begin{array}{l}3.04 \\
2.43 \\
2.03\end{array}$ & $\begin{array}{r}9.3 \\
11.7 \\
14.1\end{array}$ & $\begin{array}{l}2.12 \\
2.64 \\
3.17\end{array}$ & 650 & 0.34 & 0.42 & $\begin{array}{l}1.31 \\
2.00 \\
2.50\end{array}$ & 1.94 & \\
\hline & 257 & Star J & Hastelloy $\mathrm{C}$ & $\begin{array}{l}2.74 \\
2.19 \\
1.82\end{array}$ & $\begin{array}{r}9.3 \\
11.7 \\
14.1\end{array}$ & $\begin{array}{l}5.98 \\
7.48 \\
8.98\end{array}$ & 650 & 0.26 & 0.34 & $\begin{array}{l}1.95 \\
3.90 \\
3.25\end{array}$ & 3.03 & \\
\hline
\end{tabular}


TABLE 9

TEST DATA FROM SLIDING CONTACT TESTS IN LIQUID SODIUM

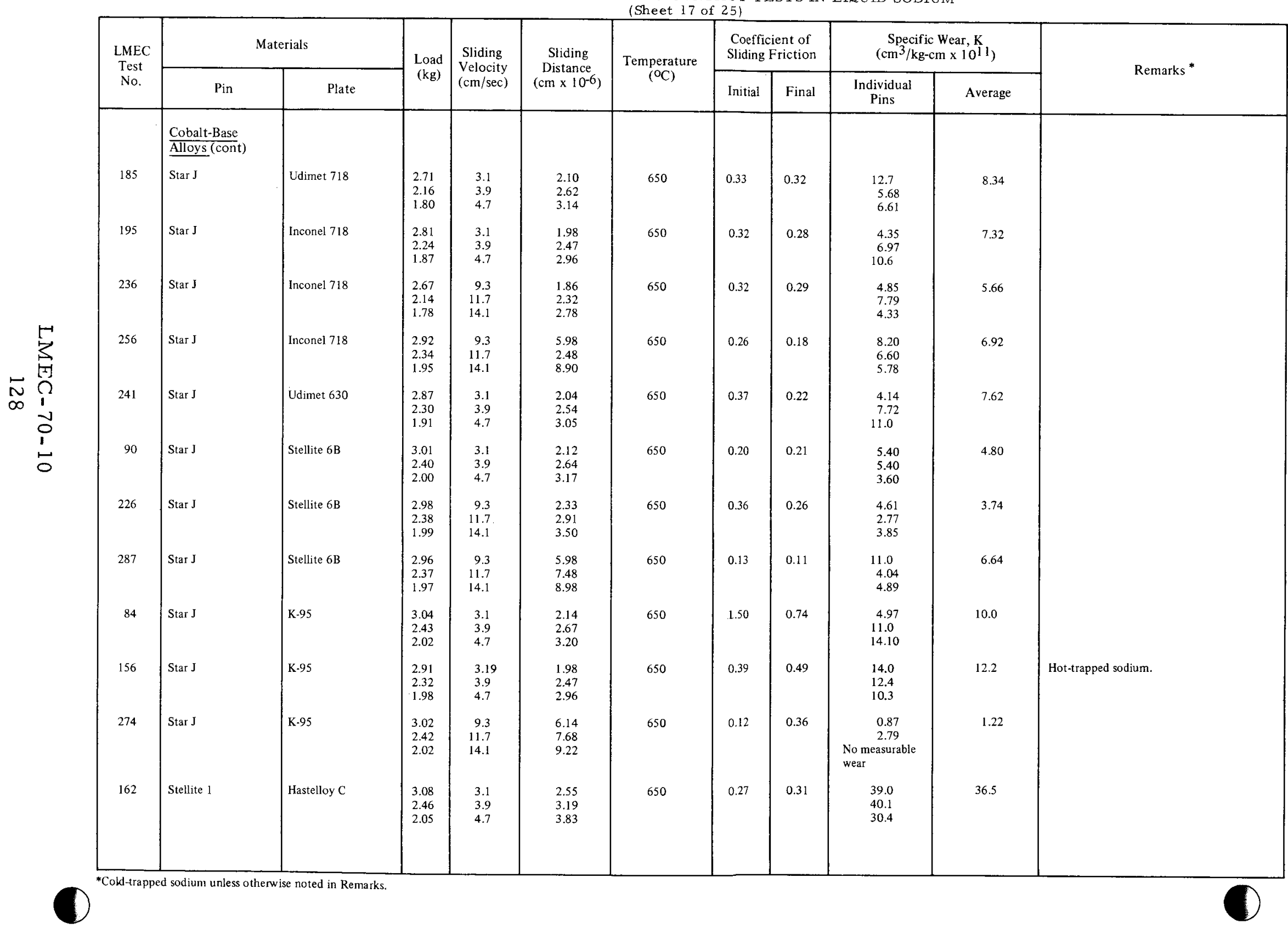


TABLE 9

TEST DATA FROM SLIDING CONTACT TESTS IN LIQUID SODIUM

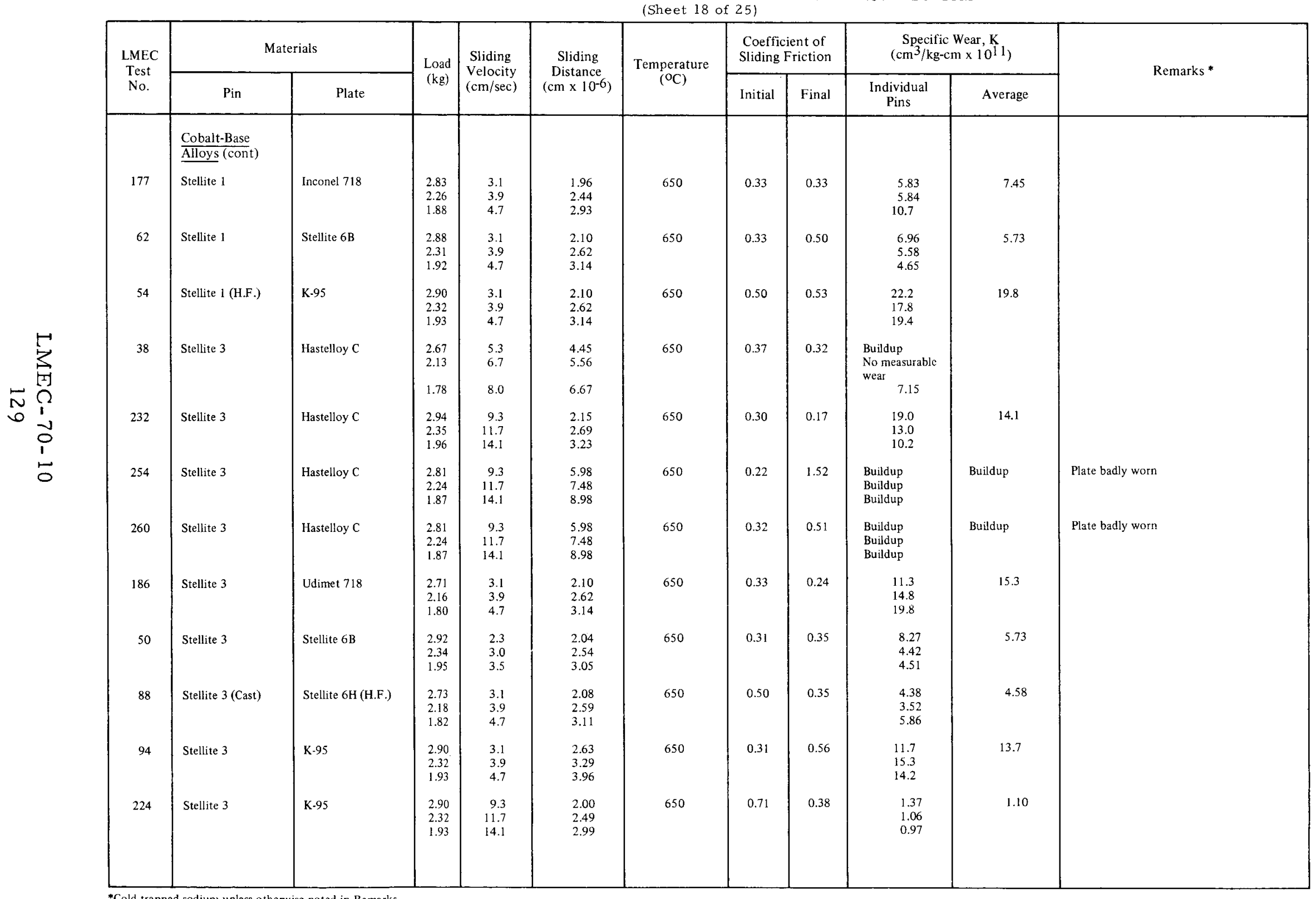


TABLE 9

TEST DATA FROM SLIDING CONTACT TESTS IN LIQUID SODIUM

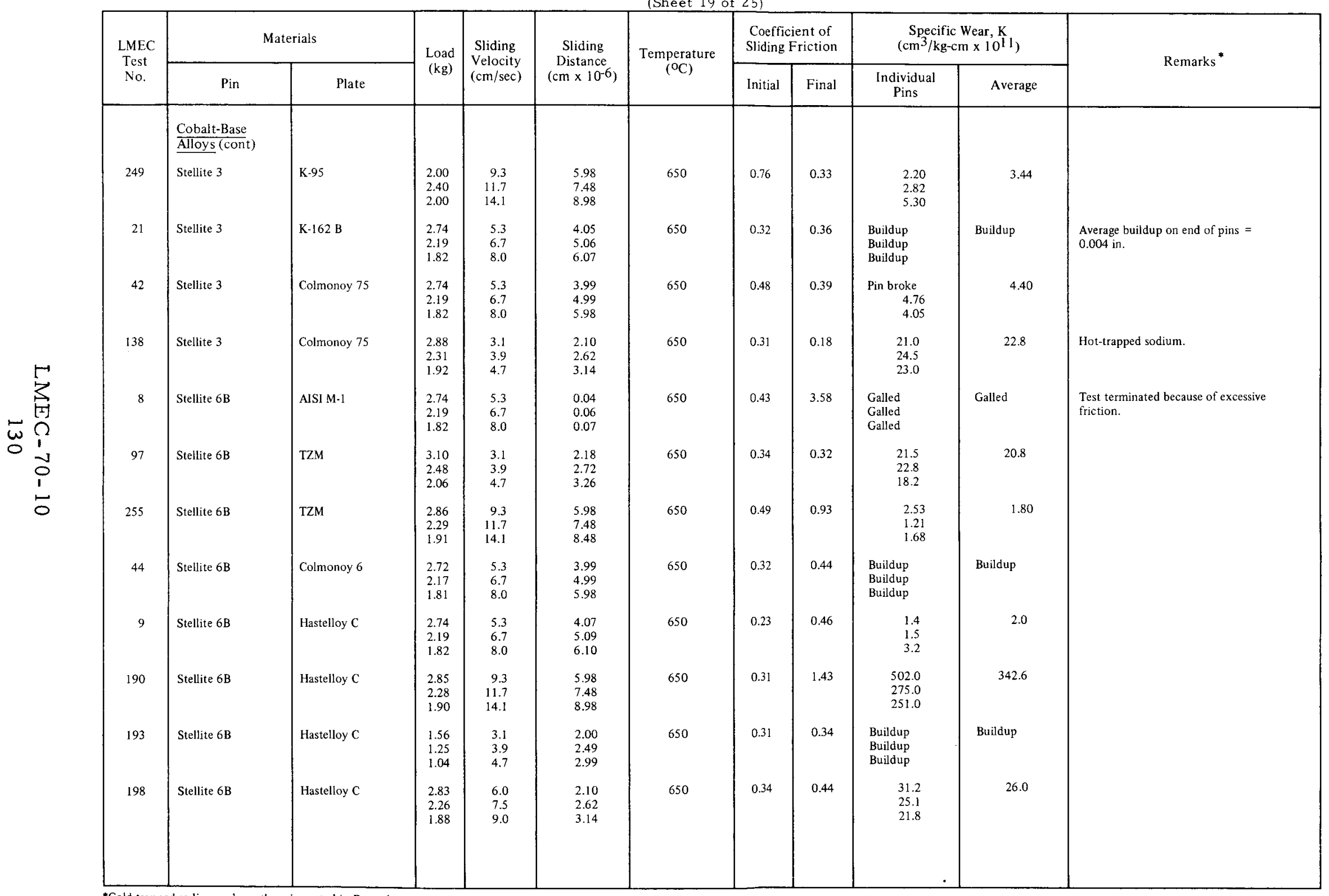

*Cold-trapped sodium unless otherwise noted in Remarks. 
TABLE 9

TEST DATA FROM SLIDING CONTACT TESTS IN LIQUID SODIUM

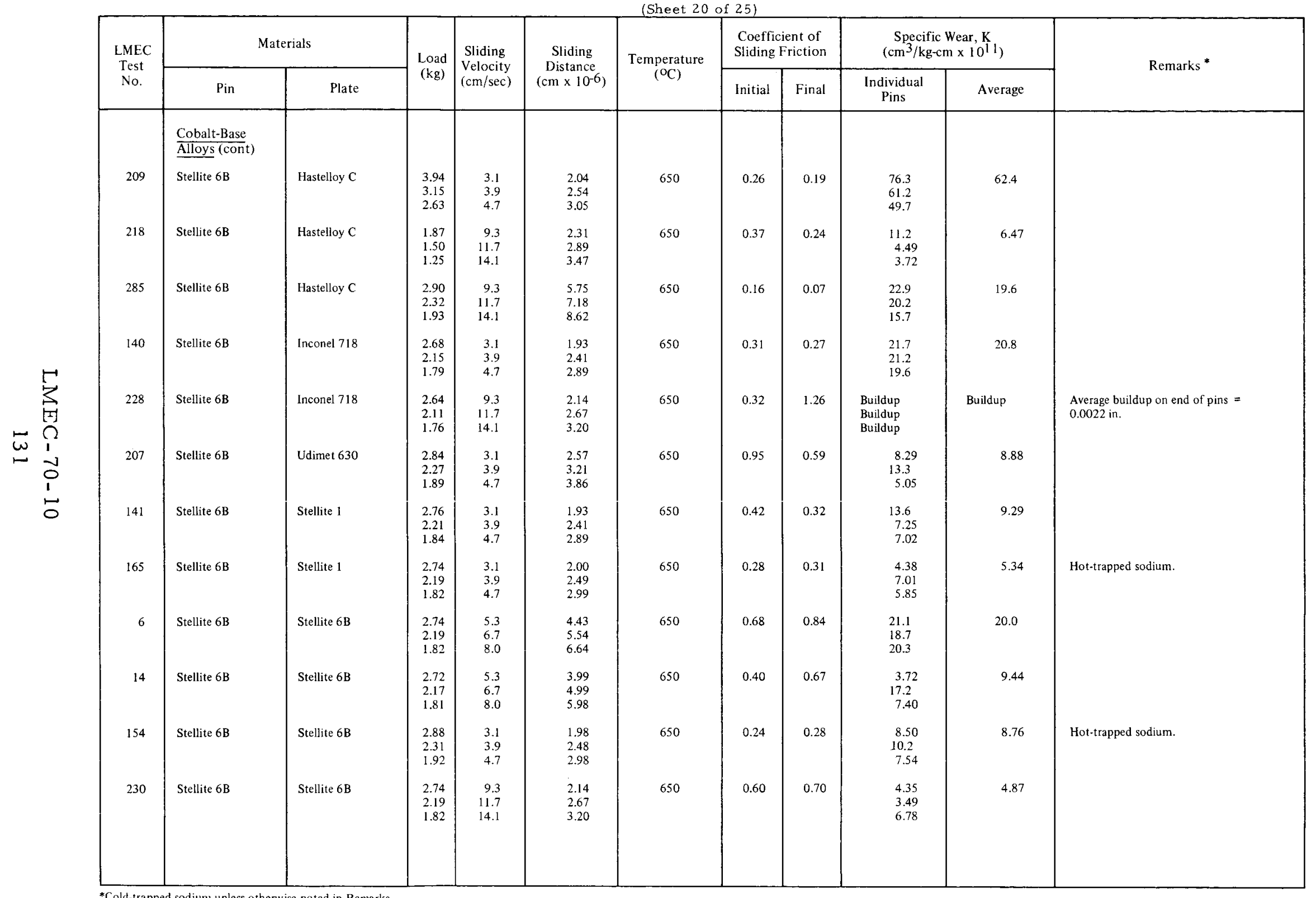


TABLE 9

TEST DATA FROM SLIDING CONTACT TESTS IN LIQUID SODIUM

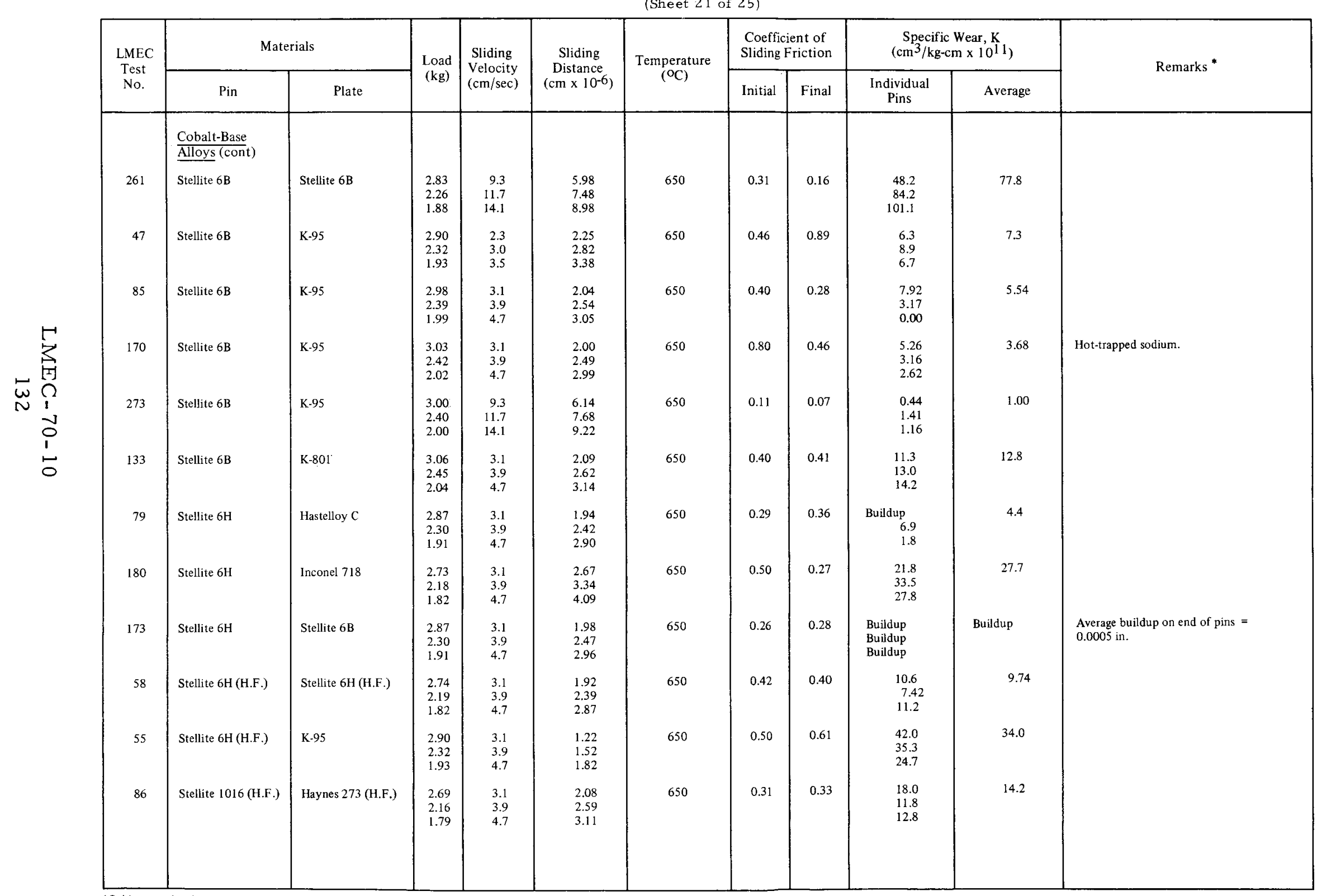


TABLE 9

TEST DATA FROM SLIDING CONTACT TESTS IN LIQUID SODIUM

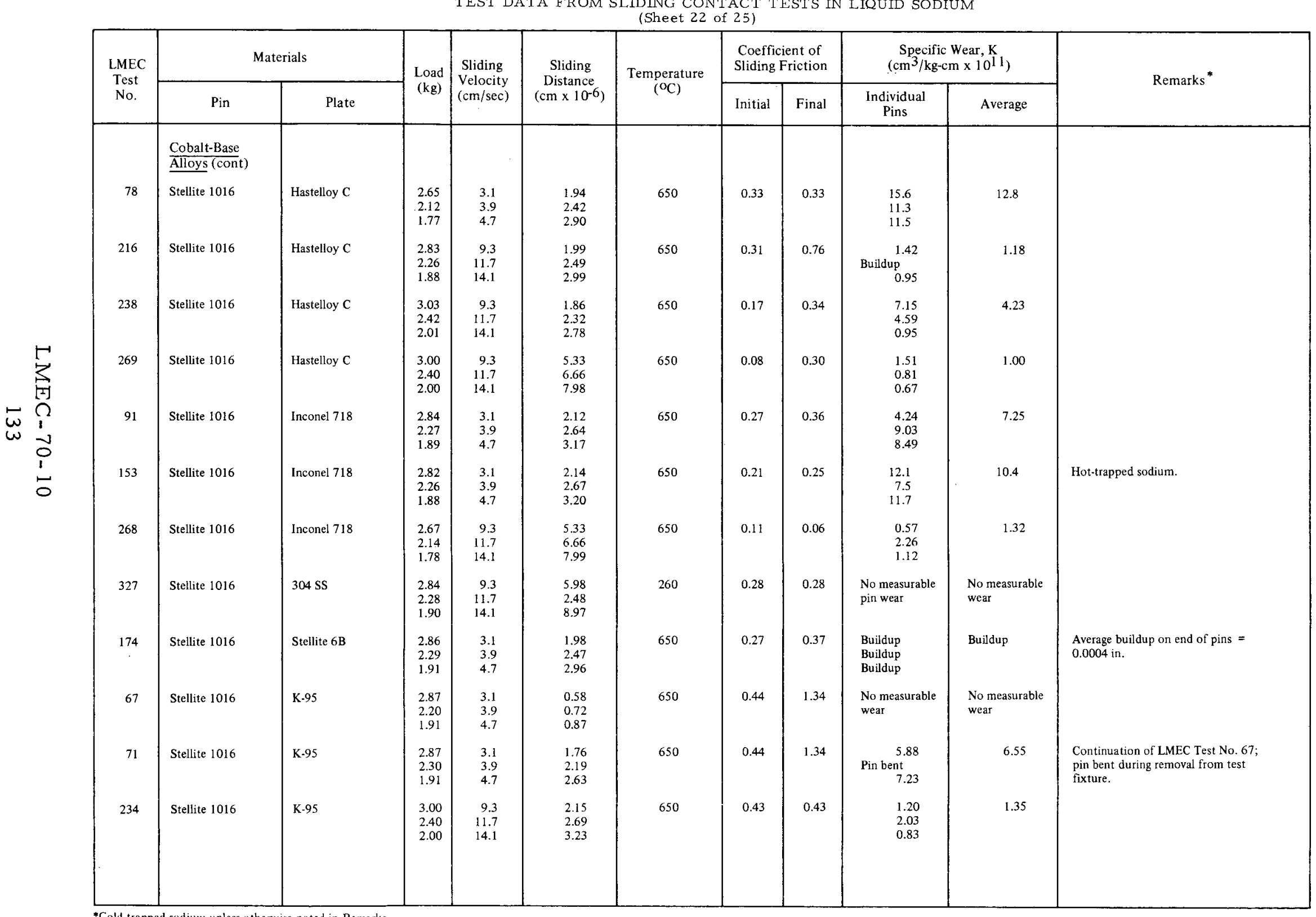


TABLE 9

TEST DATA FROM SIIDING CONTACT TESTS IN LIQUID SODIUM (Sheet 23 of 25 )

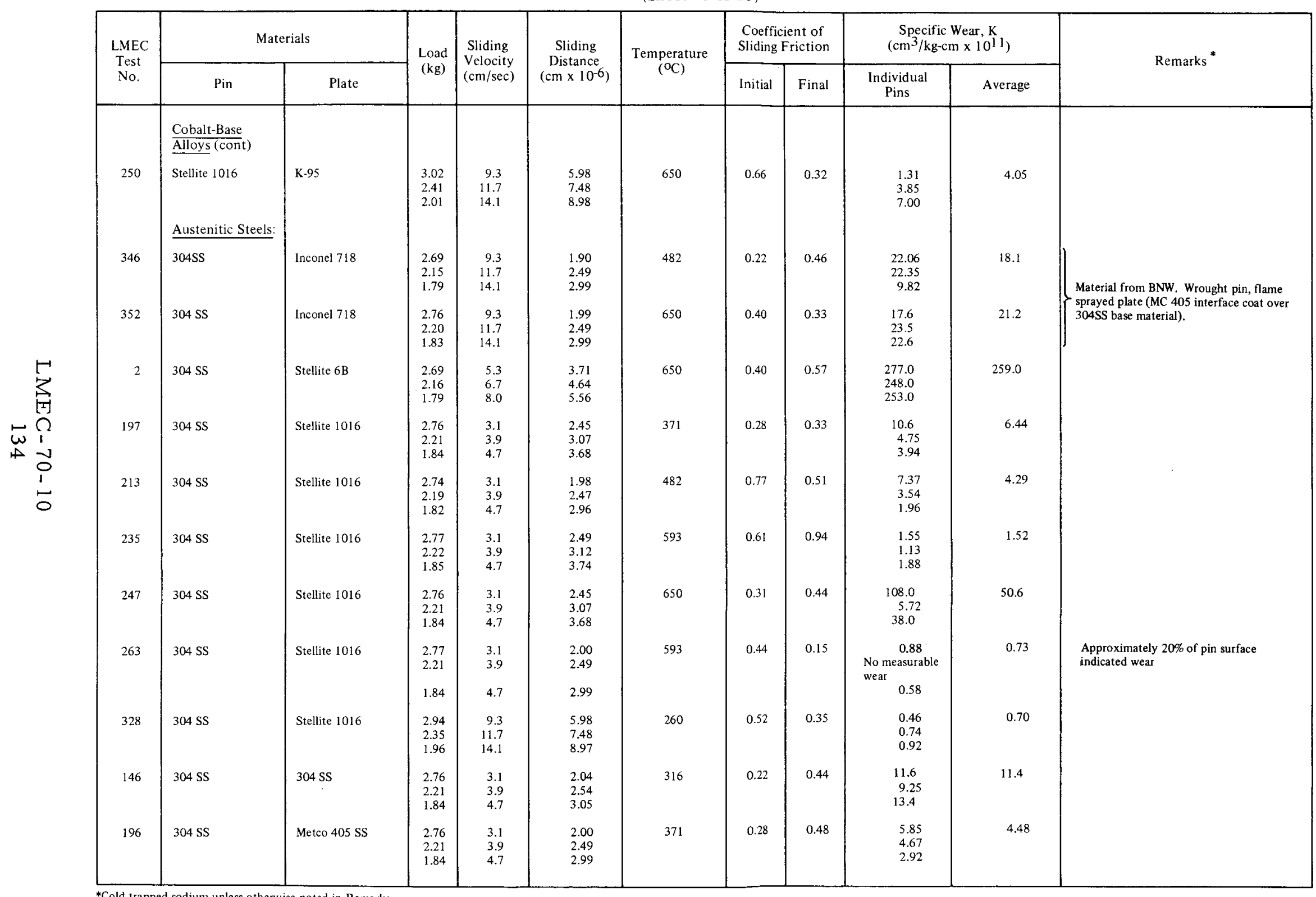


TABLE 9

TEST DATA FROM SLIDING CONTACT TESTS IN LIQUID SODIUM

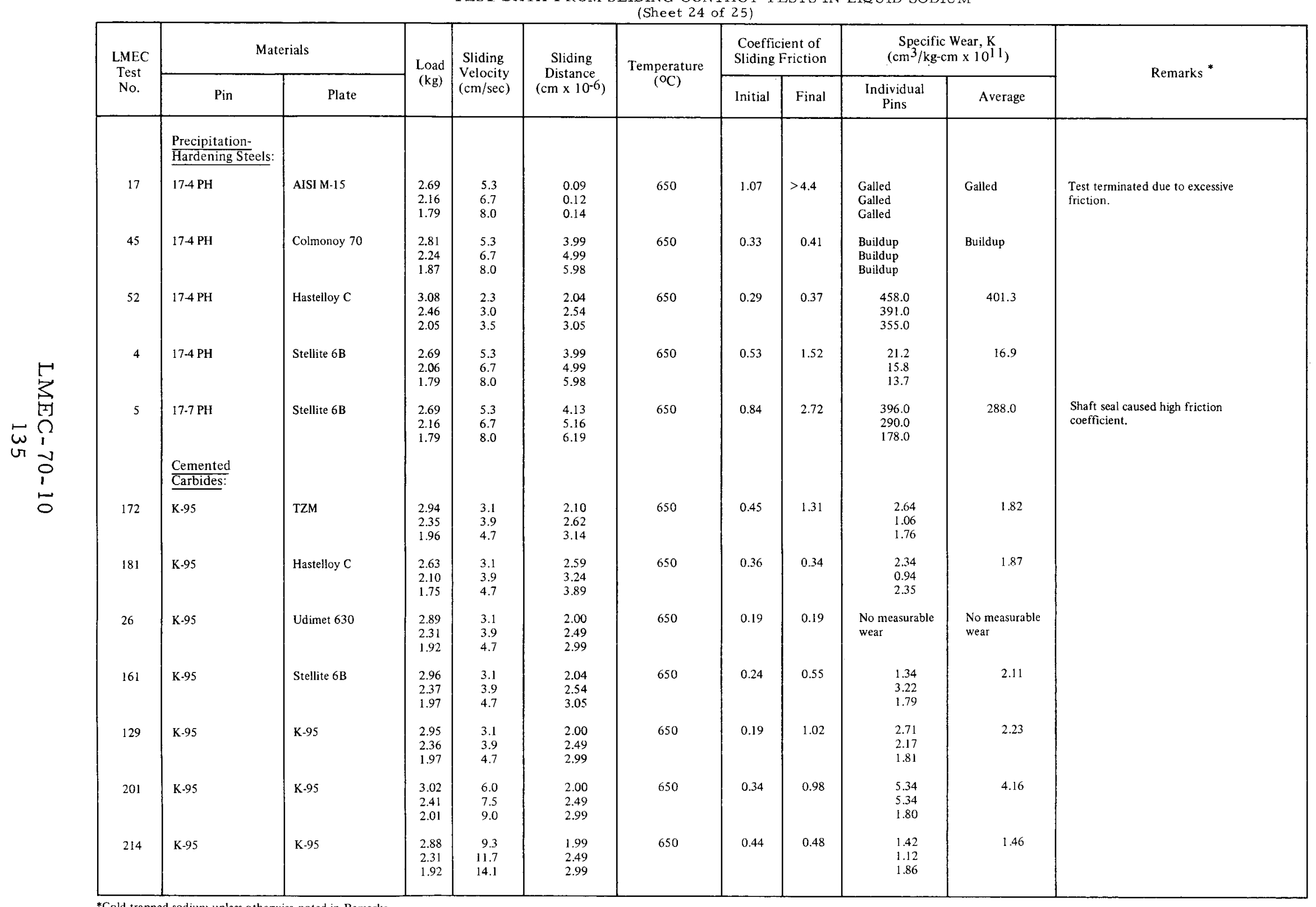


TABLE 9

TEST DATA FROM SLIDING CONTACT TESTS IN LIQUID SODIUM

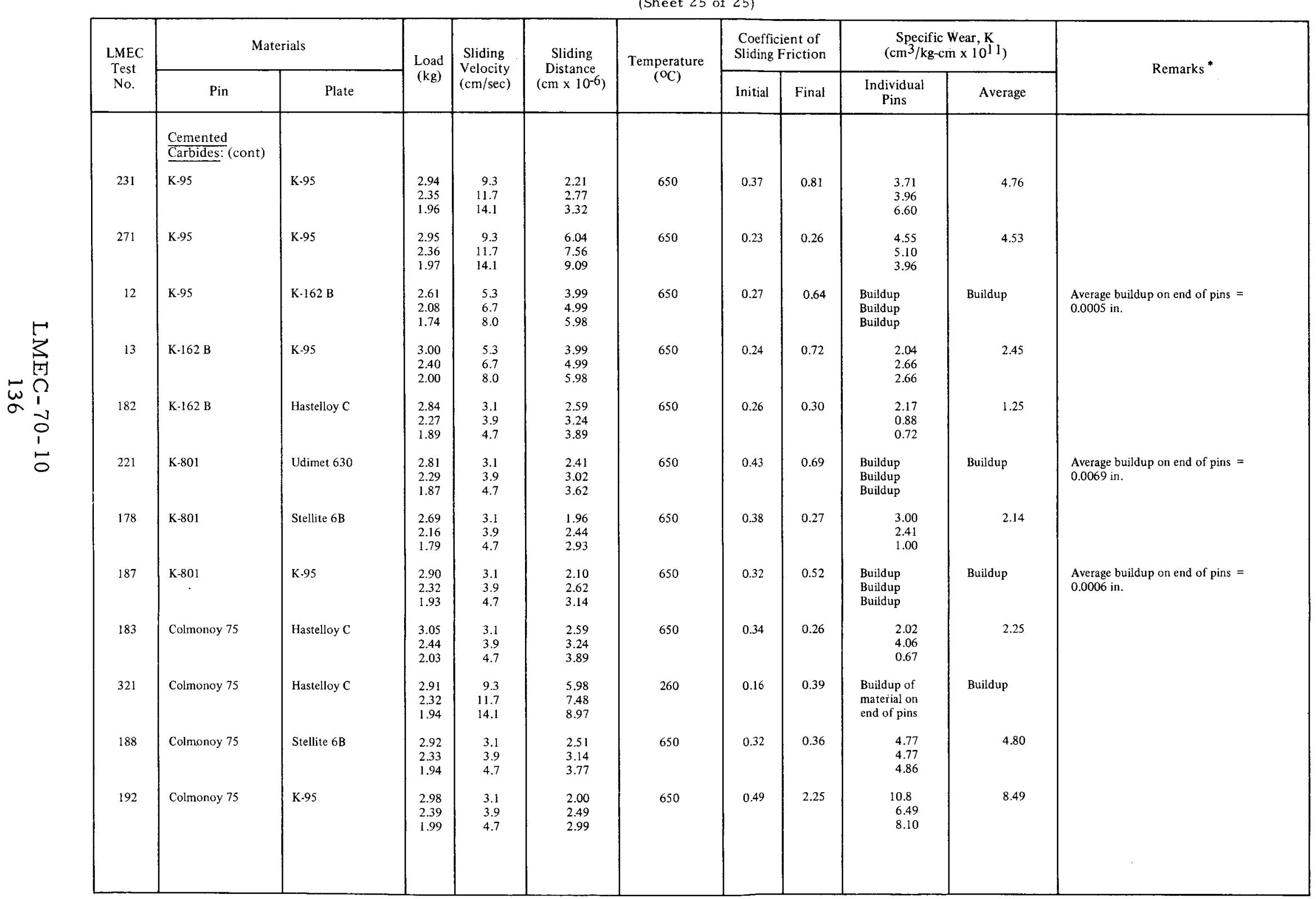


TABLE 10

TEST DATA FROM SLIDING CONTACT TESTS IN SODIUM VAPOR

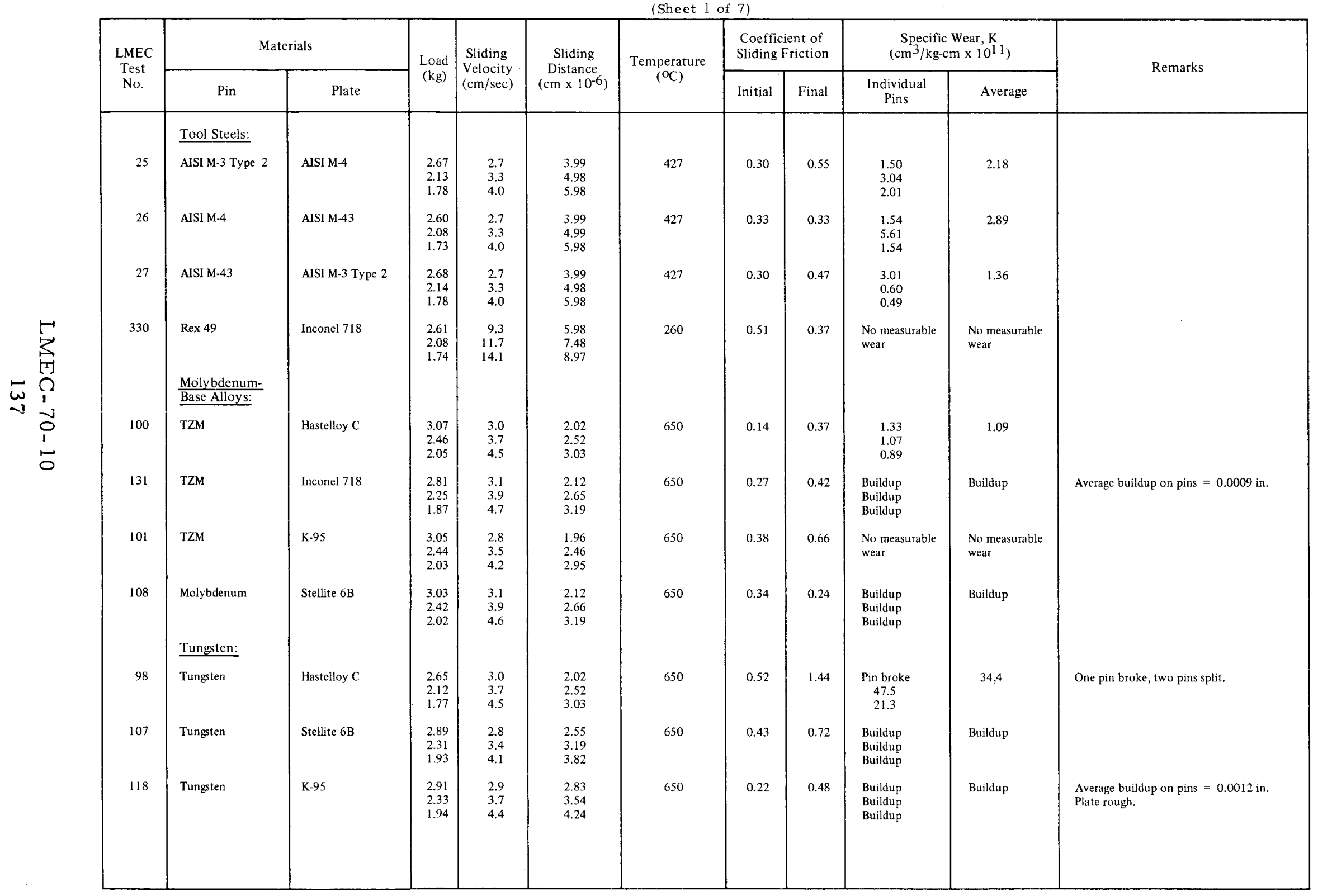


TABLE 10

TEST DATA FROM SLIDING CONTACT TESTS IN SODIUM VAPOR

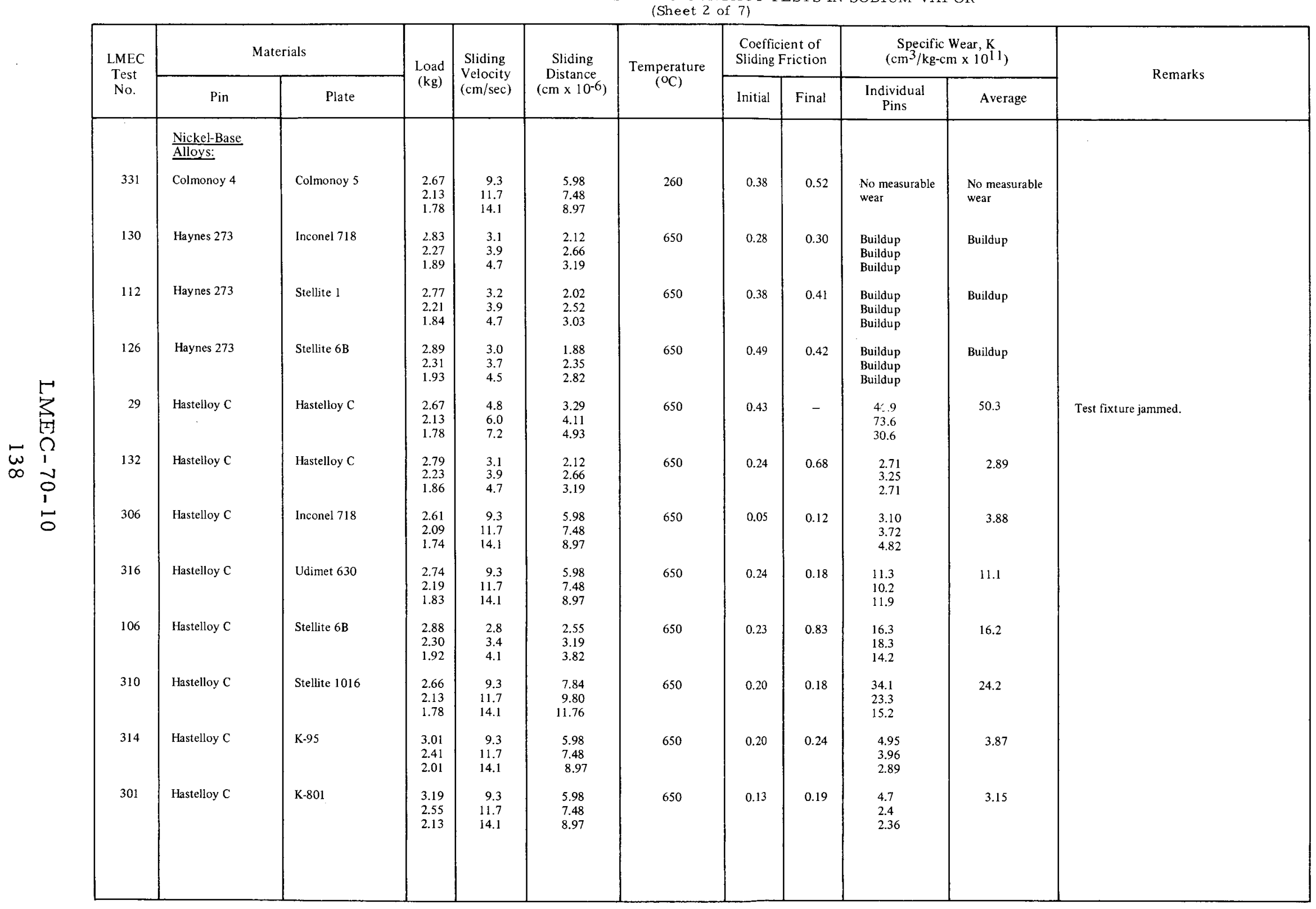


TABLE 10

TEST DATA FROM SLIDING CONTACT TESTS IN SODIUM VAPOR

\begin{tabular}{|c|c|c|c|c|c|c|c|c|c|c|c|c|}
\hline & \multirow{2}{*}{$\begin{array}{l}\text { LMEC } \\
\text { Test } \\
\text { No. }\end{array}$} & \multicolumn{2}{|c|}{ Materials } & \multirow{2}{*}{$\begin{array}{l}\text { Load } \\
(\mathrm{kg})\end{array}$} & \multirow{2}{*}{$\begin{array}{l}\text { Sliding } \\
\text { Velocity } \\
(\mathrm{cm} / \mathrm{sec})\end{array}$} & \multirow{2}{*}{$\begin{array}{c}\text { Sliding } \\
\text { Distance } \\
\left(\mathrm{cm} \times 10^{-6}\right)\end{array}$} & \multirow{2}{*}{$\begin{array}{l}\text { Temperature } \\
\quad\left({ }^{\circ} \mathrm{C}\right)\end{array}$} & \multicolumn{2}{|c|}{$\begin{array}{l}\text { Coefficient of } \\
\text { Sliding Friction }\end{array}$} & \multicolumn{2}{|c|}{$\begin{array}{c}\text { Specific Wear, } \mathbf{K} \\
\left(\mathrm{cm}^{3} / \mathrm{kg}^{2} \mathrm{~cm} \times 10^{11}\right)\end{array}$} & \multirow{2}{*}{ Remarks } \\
\hline & & Pin & Plate & & & & & Initial & Final & $\begin{array}{l}\text { Individual } \\
\text { Pins }\end{array}$ & Average & \\
\hline \multirow{14}{*}{ 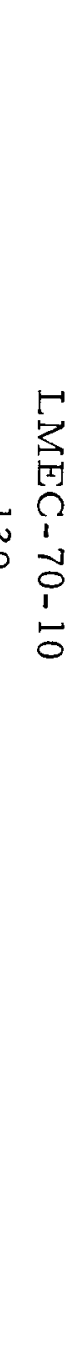 } & & $\frac{\text { Nickel-Base }}{\text { Alloys: (cont) }}$ & & & & & & & & & & \\
\hline & 336 & Hastelloy C & Colmonoy 75 & $\begin{array}{l}2.74 \\
2.19 \\
1.82\end{array}$ & $\begin{array}{r}9.3 \\
11.7 \\
14.1\end{array}$ & $\begin{array}{l}5.98 \\
7.48 \\
8.97\end{array}$ & 260 & 0.34 & 0.45 & $\begin{array}{l}0.99 \\
1.18 \\
1.34\end{array}$ & 1.17 & \\
\hline & 109 & Inconel 718 & TZM & $\begin{array}{l}3.08 \\
2.47 \\
2.05\end{array}$ & $\begin{array}{l}3.1 \\
3.9 \\
4.6\end{array}$ & $\begin{array}{l}2.13 \\
2.66 \\
3.19\end{array}$ & 650 & 0.43 & 0.51 & $\begin{array}{l}1.21 \\
0.97 \\
4.04\end{array}$ & 2.07 & \\
\hline & 311 & Inconel 718 & Hastelloy C & $\begin{array}{l}2.79 \\
2.23 \\
1.86\end{array}$ & $\begin{array}{r}9.3 \\
11.7 \\
14.1\end{array}$ & $\begin{array}{r}7.84 \\
9.80 \\
11.76\end{array}$ & 650 & 0.30 & 0.43 & $\begin{array}{l}5.55 \\
2.67 \\
2.21\end{array}$ & 3.48 & \\
\hline & 111 & Inconel 718 & Inconel 718 & $\begin{array}{l}2.70 \\
2.16 \\
1.80\end{array}$ & $\begin{array}{l}3.2 \\
3.9 \\
4.7\end{array}$ & $\begin{array}{l}2.02 \\
2.52 \\
3.03\end{array}$ & 650 & 0.53 & 0.55 & $\begin{array}{r}11.88 \\
8.31 \\
3.96\end{array}$ & 8.05 & \\
\hline & 275 & Inconel 718 & Inconel 718 & $\begin{array}{l}2.63 \\
2.10 \\
1.77\end{array}$ & $\begin{array}{r}9.3 \\
11.7 \\
14.1\end{array}$ & $\begin{array}{l}5.30 \\
6.63 \\
7.59\end{array}$ & 650 & 0.13 & 0.16 & $\begin{array}{l}4.64 \\
4.15 \\
2.32\end{array}$ & 3.70 & \\
\hline & 298 & Inconel 718 & Udimet 630 & $\begin{array}{l}2.72 \\
2.18 \\
1.82\end{array}$ & $\begin{array}{r}9.3 \\
11.7 \\
14.1\end{array}$ & $\begin{array}{l}5.98 \\
7.48 \\
8.97\end{array}$ & 650 & 0.12 & 0.25 & $\begin{array}{l}17.9 \\
16.3 \\
13.6\end{array}$ & 15.9 & \\
\hline & 125 & Inconel 718 & Stellite 6B & $\begin{array}{l}2.68 \\
2.15 \\
1.79\end{array}$ & $\begin{array}{l}3.0 \\
3.8 \\
4.5\end{array}$ & $\begin{array}{l}1.89 \\
2.38 \\
2.85\end{array}$ & 650 & 0.37 & 0.62 & $\begin{array}{l}1430 . \\
1640 . \\
1298 .\end{array}$ & 1456. & \\
\hline & 278 & Inconel 718 & Stellite 6B & $\begin{array}{l}3.00 \\
2.40 \\
2.00\end{array}$ & $\begin{array}{r}9.3 \\
11.7 \\
14.1\end{array}$ & $\begin{array}{l}6.69 \\
8.25 \\
9.89\end{array}$ & 650 & 0.64 & 0.32 & $\begin{array}{l}11.9 \\
7.54 \\
3.82\end{array}$ & 7.75 & \\
\hline & 299 & Inconel 718 & Stellite 1016 & $\begin{array}{l}2.81 \\
2.25 \\
1.87\end{array}$ & $\begin{array}{r}9.3 \\
11.7 \\
14.1\end{array}$ & $\begin{array}{l}5.98 \\
7.48 \\
8.97\end{array}$ & 650 & 0.11 & 0.22 & $\begin{array}{l}14.9 \\
16.1 \\
21.4\end{array}$ & 17.3 & \\
\hline & 309 & Inconel 718 & Stellite 1016 & $\begin{array}{l}2.95 \\
2.36 \\
1.97\end{array}$ & $\begin{array}{r}9.3 \\
11.7 \\
14.1\end{array}$ & $\begin{array}{l}5.98 \\
7.48 \\
8.97\end{array}$ & 650 & 0.22 & 0.22 & $\begin{array}{l}12.4 \\
19.8 \\
27.1\end{array}$ & 19.7 & \\
\hline & 282 & Inconel 718 & K.95 & $\begin{array}{l}2.89 \\
2.31 \\
1.93\end{array}$ & $\begin{array}{r}9.3 \\
11.7 \\
14.1\end{array}$ & $\begin{array}{l}6.06 \\
7.58 \\
9.09\end{array}$ & 650 & 0.24 & 0.24 & $\begin{array}{l}3.24 \\
2.60 \\
2.50\end{array}$ & 2.78 & \\
\hline & 312 & Udimet 630 & Hastelloy C & $\begin{array}{l}2.77 \\
2.22 \\
1.85\end{array}$ & $\begin{array}{r}9.3 \\
11.7 \\
14.1\end{array}$ & $\begin{array}{l}7.84 \\
9.80 \\
11.7\end{array}$ & 650 & 0.13 & 0.22 & $\begin{array}{l}4.42 \\
2.38 \\
1.99\end{array}$ & 2.93 & \\
\hline & 277 & Udimet 630 & Inconel 718 & $\begin{array}{l}2.66 \\
2.13 \\
1.77\end{array}$ & $\begin{array}{r}9.3 \\
11.7 \\
14.1\end{array}$ & $\begin{array}{l}5.98 \\
7.48 \\
8.97\end{array}$ & 650 & 0.12 & 0.36 & $\begin{array}{l}19.7 \\
26.3 \\
43.2\end{array}$ & 29.7 & \\
\hline
\end{tabular}


TABLE 10

TEST DATA FROM SLIDING CONTACT TESTS IN SODIUM VAPOR

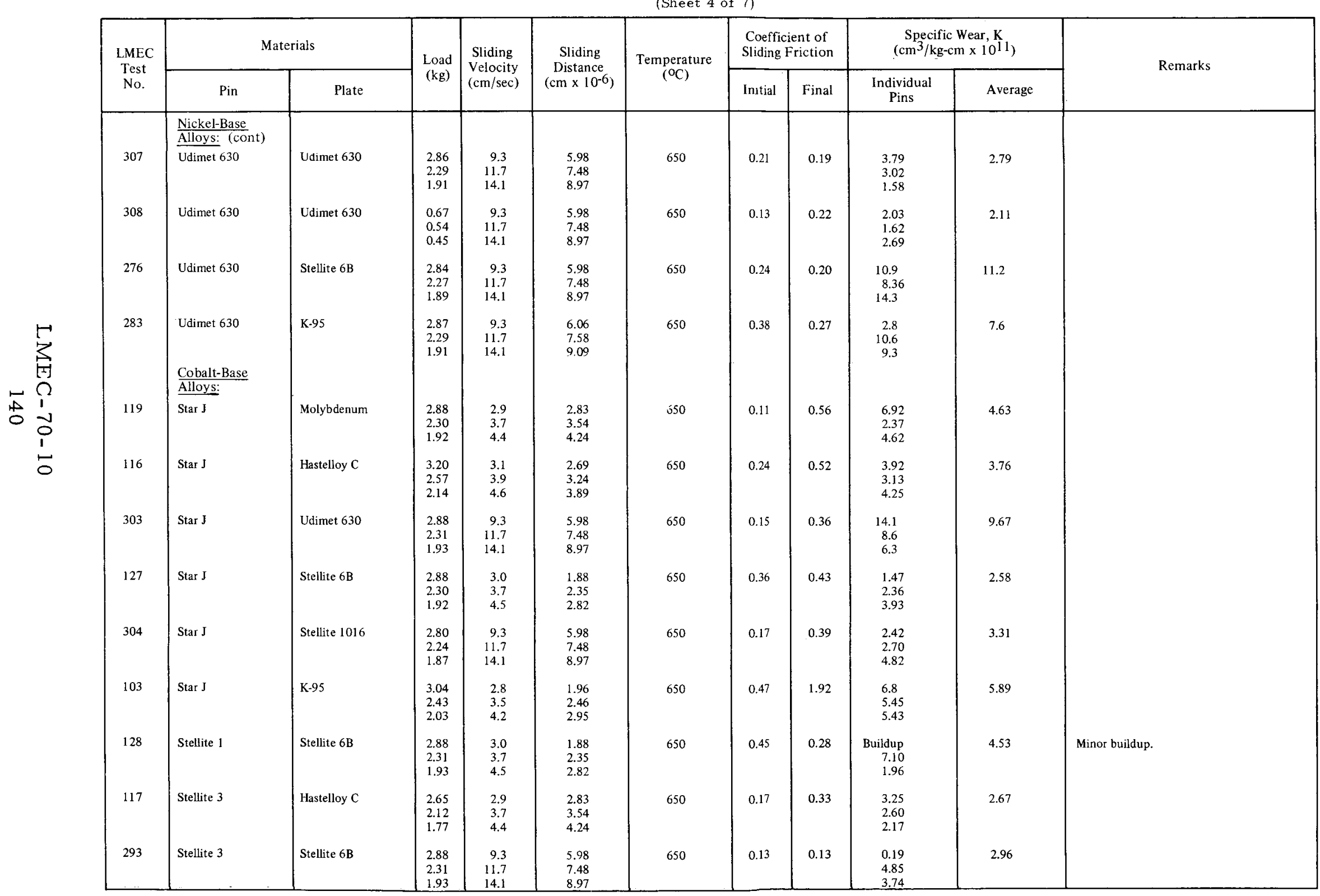


TABLE 10

TEST DATA FROM SLIDING CONTACT TESTS IN SODIUM VAPOR

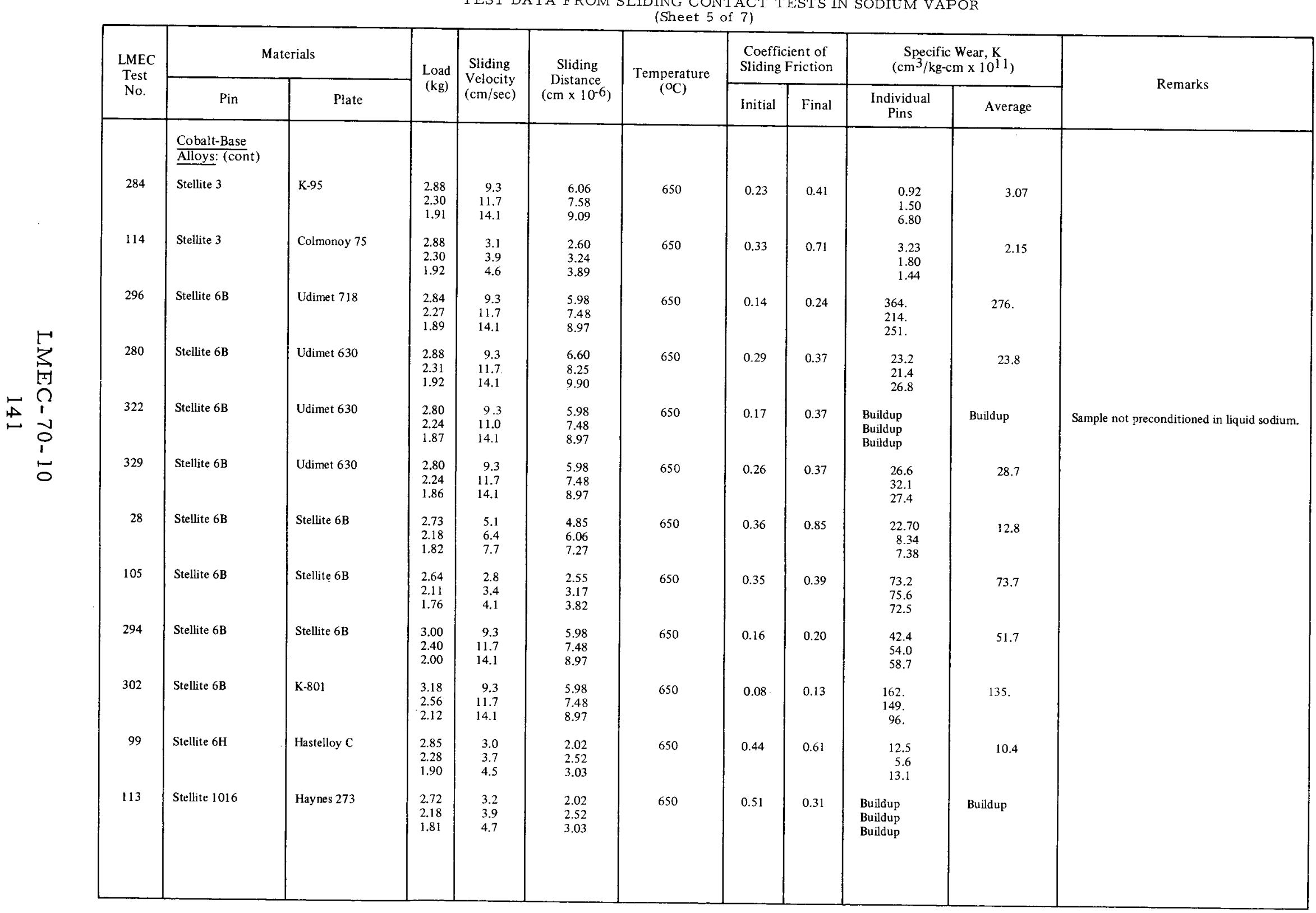


TABLE 10

TEST DATA FROM SLIDING CONTACT TESTS IN SODIUM VAPOR (Sheet 6 of 7)

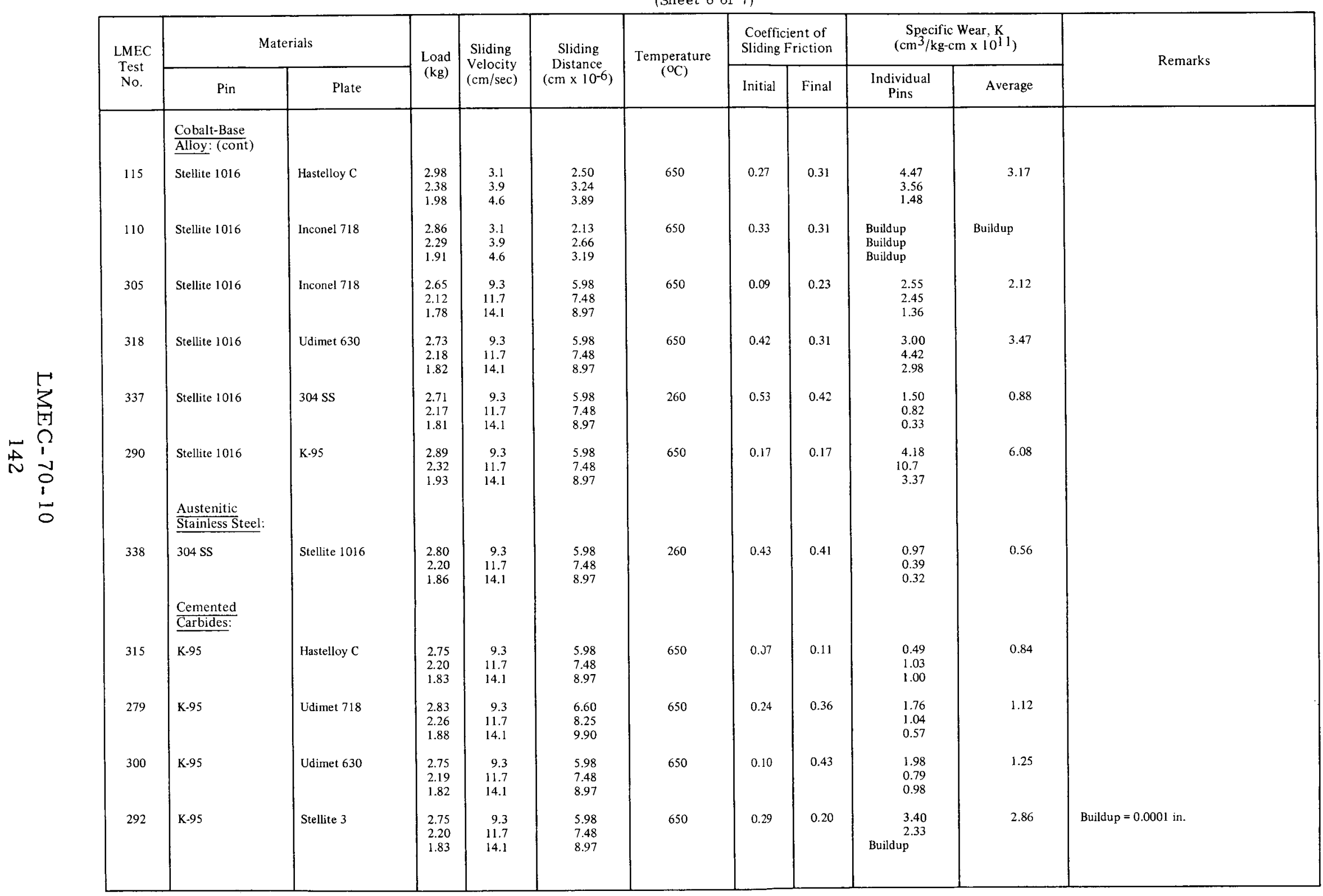


TABLE 10

TEST DATA FROM SLIDING CONTACT TESTS IN SODIUM VAPOR

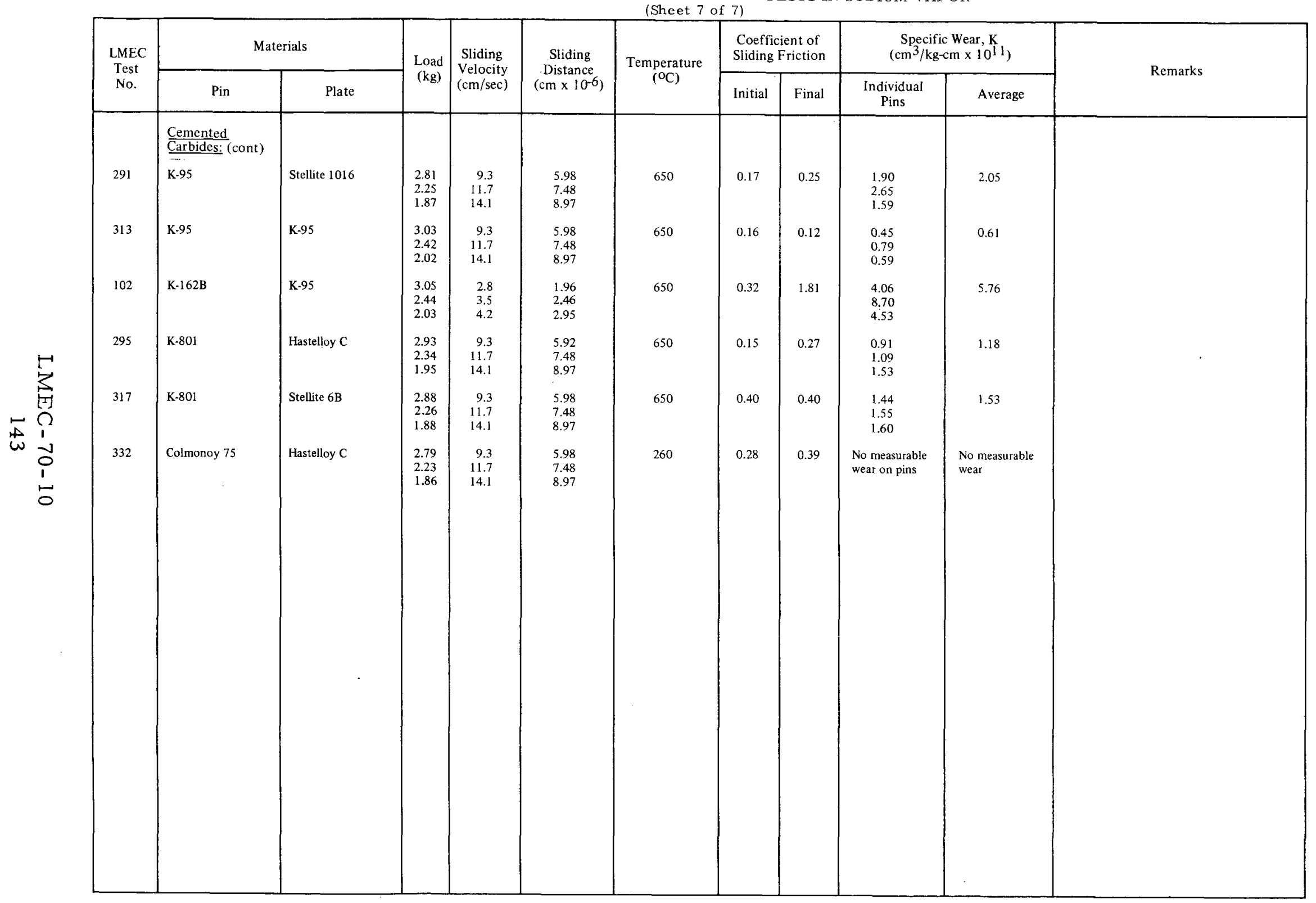




\section{DISCUSSION}

\section{A. STATIC CONTACT TEST RESULTS}

In examining the coefficients that represent the "breakaway" phenomena (Tables 8A and 8B) an apparent overwhelming amount of scatter is noted. Any model proposed to describe static "self-welding" in sodium must include potential reasons for this apparent scatter in the data. As described previously, the test included pushing the metal couple together under pressure, hemisphere against plane, in sodium at $1200^{\circ} \mathrm{F}$ for long periods of time. The breakaway friction coefficient is the force required to shear the joined asperities of the two surfaces divided by the applied load perpendicular to the contact surface.

Five major phenomena occur which affect the static friction coefficient after long-time exposure to hot sodium. The most important is that surface films have moved toward their equilibrium state in the total system under consideration; i. e., metastable films may have dissolved into the metal or polyoxides may have formed with metal atoms from a different part of the system. The second phenomenon is metallurgical change due to the high temperature; cold-worked metals can anneal, and certain alloys can age or overage. The third phenomenon involves changes in actual area of the friction junctions as a result of creep deformation (see Figure 18) or because of sintering action that builds up the necks of joined asperities and rounds off the intersections between asperities. The fourth phenomenon is the change in mechanical properties due to mass transfer of interstitial elements, particularly carbon. If wear debris, keyed into each of the two contact surfaces by the rubbing action, begins to carburize, the coefficient of static friction could increase drastically as such a particle would no longer shear but would have to penetrate through the surfaces. The fifth phenomenon is mass transfer of structural material through the sodium.

Of the mechanisms listed above, the second would lower friction while the third, fourth, and, in general, the fifth would raise the friction. The first mentioned and dominant phenomenon could either raise or lower the friction. Since this phenomenon is a function of all materials present in the entire system, any tests of an isolated couple in a vessel fabricated of one of the materials of the couple would not be representative of an actual system.

If surface film effects are dominant, then one type of behavior below a transition temperature and another behavior above could be expected. The 


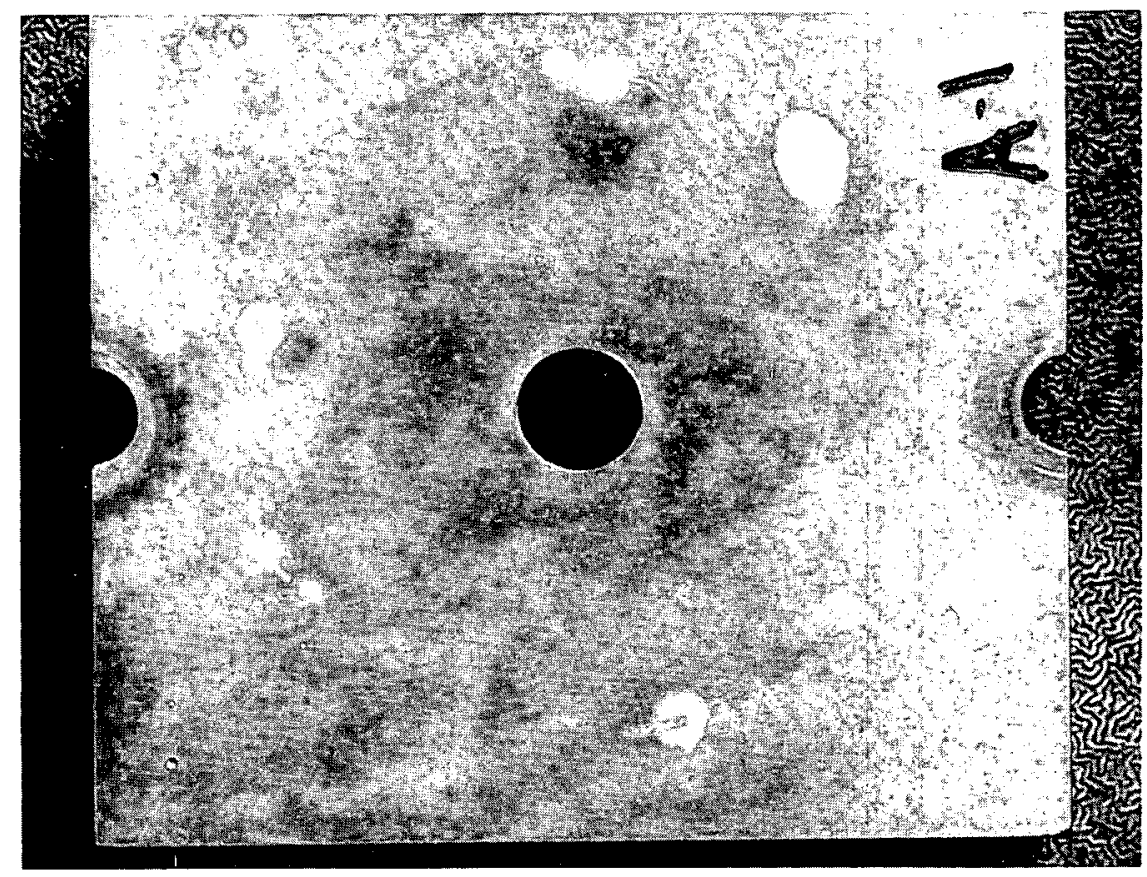

AISI T1 PLATE

7694-1028

Figure 18. Evidence of Creep Deformation in Static Tests

(Each mark represents a different time at temperature under load.)

effect of oxygen content would be to raise or lower that transition temperature. In general, the transition would be from a lower to a higher coefficient of friction as temperature is raised; and raising the oxygen content would most likely increase the temperature range of low friction coefficient. If chromium is the controlling metal atom, the transition temperature for low oxygen sodium is likely to be in the low $900^{\circ} \mathrm{F}$ range. Since these tests were performed at $1200^{\circ} \mathrm{F}$ in austenitic stainless-steel vessels, the results are probably applicable to high coefficient-of-friction behavior.

In sodium vapor, carburization of wear debris and mass transfer of structural material are not important mechanisms. Since these two mechanisms contribute to increased coefficients of friction, the vapor exposures might be expected to result in lower static friction coefficients. The fact that such a trend is not very noticeable merely reemphasizes the dominance of the surface film mechanism. The effect of other materials in the system on film formation should be much less in the vapor tests, however. 
A graph showing the distribution of static coefficient of friction values can serve as a diagnostic aid in the search for equilibrium film effects. Hopefully, certain elements will result in characteristic coefficients after sufficient times in sodium. Such a graph constructed from LMEC results is given in Figure 19. The peaks generally will represent equilibrium polyoxide effects, with the exception of the peak representing values greater than 3.3. These high values often represent the interstitial atom mass transfer phenomenon discussed above, where keyed-in debris particles and asperities carburize and harden. Other peaks could not be identified with alloy components or known phenomena, with the possible exceptions of the peak at 0.4 with silicate and/or borate films and the peak at 2.1 with vanadates and/or tungstates. These identifications are quite tentative. No distinct difference between liquid and vapor was noted.

\section{B. SIIDING CONTACT RESULTS}

\section{Correlation with Wear Theory}

The massed results of the sliding contact tests are best understood in terms of a model or equation for wear. There have been many attempts to do this in the past, ranging from Bowden and Tabor's classic work ${ }^{(20,21)}$, the thorough work of Archard and Rabinowicz, ${ }^{(22,23)}$ through the recent efforts of Sowa, et al. (24) It is believed that these models and equations explain inadequately LMEC's results on pin wear* and LMEC proposes a new way of expressing the wear equation for pin rubbing. This new expression of the wear equation is based, to a considerable degree, on the examination of scanning electron microscope photographs, the lack of linearity in plots of wear versus load, and the lack of a quantitative relationship between wear and coefficient of friction. The scanning electron microscope photographs clearly indicate that entirely separate types of wear can thoroughly dominate the wear process. This leads to the conclusion that individual wear terms must be additive. In the past, the following relationship has been assumed:

$$
\left(\frac{\mathrm{V}}{\mathrm{s}}\right) \alpha \mathrm{w}, \text { or }\left(\frac{\mathrm{V} / \mathrm{s}}{\mathrm{w}}\right)=\mathrm{K}
$$

\footnotetext{
* Wear on the plates is not amenable to analysis since the distance of sliding contract that a point on the plate experiences is too sensitive to the geometry of the experimental set-up to be of use.
} 


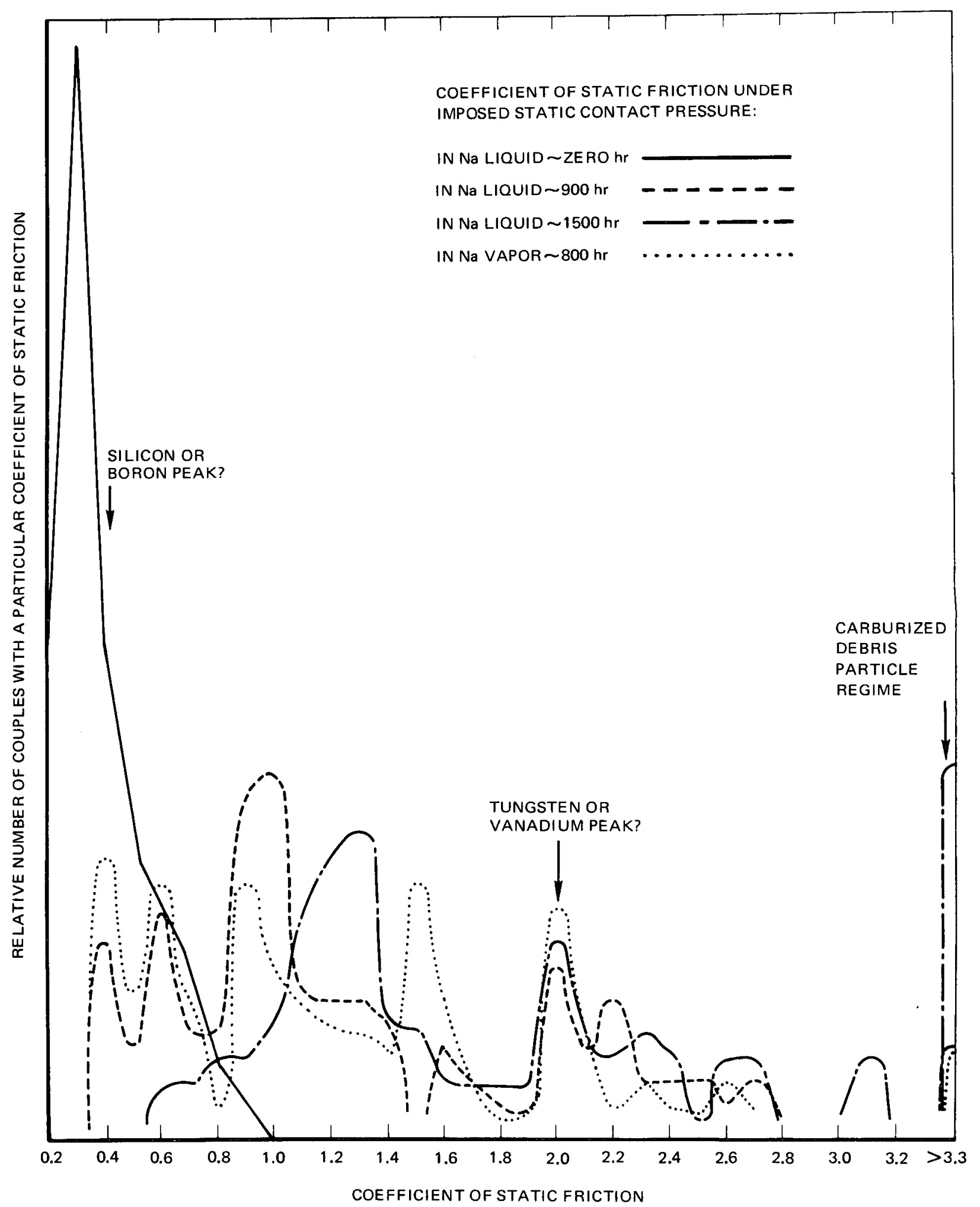

$7693-4734$

Figure 19. Distribution of Static Coefficient of Friction in a Sodium Environment 
where

$$
\begin{aligned}
& \mathrm{K}=\text { wear coefficient } \\
& \frac{\mathrm{V}}{\mathrm{s}}=\text { rate of wear in (volume lost)/(distance traveled) } \\
& \mathrm{w}=\text { applied load. }
\end{aligned}
$$

Since volume equals area, A, times depth of wear, $h$,

$$
\mathrm{K}=\left(\frac{\mathrm{Ah}}{\mathrm{s}}\right) / \mathrm{w} \equiv(\mathrm{h} / \mathrm{s}) / \mathrm{P}
$$

where

$$
\mathrm{P}=\text { the applied pressure. }
$$

This relationship assumes that $(\mathrm{V} / \mathrm{s})$ plotted against $\mathrm{w}$, or $(\mathrm{h} / \mathrm{s})$ plotted against $P$, would yield a straight line of slope $K$. As discussed previously, this may not be true at either low loads or very high loads.

A better parameter than $\mathrm{K}$, then, might be $(\mathrm{h} / \mathrm{s})_{\mathrm{P}, \mathrm{T}}$, the depth worn per distance traveled at a constant pressure and temperature.

$$
\begin{aligned}
\left(\frac{h}{s}\right)_{P, T}= & f_{1}(n)+f_{2}\left(\frac{\epsilon}{d}\right)+f_{3}\left(B_{1}\right)+f_{4}\left(B_{2}, N, \frac{d N}{d s}, \bar{r}, D, \frac{d \bar{r}}{d s}, r_{\max }, R\right) \\
& +f_{5}(v)+f_{6}(\mu),
\end{aligned}
$$

where

$$
\begin{aligned}
\mathrm{n}= & \text { work hardening exponent of pin material } \\
\mu= & \text { coefficient of friction } \\
\mathrm{v}= & \text { velocity of rubbing in fraction of sonic velocity in solid } \\
\mathrm{B}_{1}= & \text { ratio of hot hardness difference between plate and pin to hot hardness } \\
& \text { of pin } \\
\mathrm{B}_{2}= & \text { ratio of hot hardness difference between particles and pin to hot } \\
& \text { hardness of pin }
\end{aligned}
$$




$$
\begin{aligned}
\epsilon= & \text { surface finish } \\
\mathrm{d}= & \text { film thicknes } \\
\mathrm{N}= & \text { (number of particles generated - number of particles lost/width of } \\
& \text { wear path) (unit length of wear path) } \\
\mathrm{dN} / \mathrm{d} s= & \mathrm{d}(\mathrm{N} \text { generated }-\mathrm{N} \text { lost)/d(length of wear path) } \\
\overline{\mathrm{r}}= & \text { average radius of particles doing plowing } \\
\mathrm{r} \max = & \text { maximum particle radius } \\
\frac{\mathrm{d} \overline{\mathrm{r}}}{\mathrm{d} s}= & \text { change in } \overline{\mathrm{r}} \text { per unit length of wear path } \\
\mathrm{D}= & \text { width of wear track } \\
\mathrm{R}= & \text { number of repeats on some wear track. }
\end{aligned}
$$

Adhesive wear is included in the first and last term. The effect of surface films and surface roughness, though these also affect the friction term, are represented separately as the second term as it is felt that there are beneficial wear effects from thick films due to enhanced removal of wear particles. Such an effect would not show up in the coefficient of friction term. The third term, the two-body abrasion term, includes within it relative modulus data as a rough relationship exists between modulus and hardness. The third term also includes high cycle surface fatigue behavior, since this is a function of hardness. The fourth term attempts to evaluate the role of particles in machining away the pin and represents the three-body abrasion term. The fifth term, which is the velocity term, is only incidently a measure of the heat generated at the surfaces. The ability of a material to conduct heat away should also influence the first term. The velocity term here represents the change in ability to accept deformation without fracture as a function of impact velocity.

One important point that the above equation illustrates is the futility of trying to predict wear by the coefficient of friction or relative hot hardness values alone. Under certain conditions, certain terms in the above equation will dominate. Under conditions when the fourth term predominates, the perusal of known test conditions may lead to apparently unexplicable scatter in wear data, particularly when an unusually large wear debris particle may be active.

\section{LMEC-70- 10}


This equation differs considerably from the one developed by Sowa, et al. (24)

$$
C_{W}=K_{l}\left[\frac{\mathrm{B}_{3} \mathrm{~A}}{\mathrm{~F}}\right]^{\mathrm{n}}=\mathrm{K}_{1}\left[\frac{\mathrm{B}_{3}}{\mathrm{P}}\right]^{\mathrm{n}},
$$

where

$$
\begin{aligned}
K_{1} & =\text { a coefficient in units of } \mathrm{in.}^{3} /(\min )\left(\mathrm{in}^{2}\right)(\mathrm{lb}) \\
B_{3} & =\text { hot hardness of one surface, expressed as } 1 \mathrm{~b} / \mathrm{in.}^{2} \\
\mathrm{~A} & =\text { area } \\
\mathrm{F} & =\text { applied force } \\
\mathrm{n} & =\text { an exponent } \\
C_{\mathrm{w}} & =\text { coefficient of mechanical wear in units of } \mathrm{in}^{3} /(\min )\left(\mathrm{in}^{2}\right)(\mathrm{lb}) \cdot
\end{aligned}
$$

Sowa's equation originally included other terms before simplification:

$$
C_{w}=K_{2} \epsilon^{a} v^{e} p^{f} B_{3} g_{E}^{h}
$$

where a, e, f, $g$, and $h$ are exponents and $E=$ modulus of elasticity.

In this equation, a small value of any effect lowers the wear coefficient, $\mathrm{C}_{\mathrm{w}}$; whereas if the effects are summed, wear may still be high under certain conditions even if, for example, $\mu$ is low. Such conditions were active upon occasion in LMEC testing, for LMEC has data representing high wear on combinations with low $\mu$ values. In the majority of cases in LMEC testing, the fourth term did not predominate and the effects of the pin material could be estimated.

The equation LMEC has written for $\alpha$ is very general with the parameters entering in an undefined manner. These parameters are expressible in a dimensionless manner. One possibility is shown below as follows: 


$$
\begin{gathered}
(\mathrm{h} / \mathrm{s})_{\mathrm{P}, \mathrm{T}}=\mathrm{K}_{1} \mathrm{n}^{\mathrm{a}}+\mathrm{K}_{2}(\epsilon / \mathrm{d})^{\mathrm{b}}+\mathrm{K}_{3}\left(\frac{\mathrm{B}_{\text {plate }}}{\mathrm{B}_{\text {plate }}-\bar{B}_{\text {pin }}}\right)^{\mathrm{c}} \\
+\mathrm{K}_{4}\left(\frac{\mathrm{B}_{\text {particle }}}{\mathrm{B}_{\text {particle }}-\mathrm{B}_{\text {pin }}}\right)^{\mathrm{d}}\left(\mathrm{N}_{\mathrm{i}}+\frac{\mathrm{dN} \mathrm{N}_{\mathrm{i}} \mathrm{s}}{\mathrm{ds}}\right)^{\mathrm{e}}\left(\frac{\overline{\mathrm{r}}}{\mathrm{D}}+\frac{\mathrm{d} \overline{\mathrm{r}}}{\mathrm{ds}} \cdot \frac{\mathrm{s}}{\mathrm{D}}\right)^{\mathrm{f}}\left(\frac{\mathrm{r}_{\max }}{\mathrm{D}}\right)^{\mathrm{g}}(\mathrm{R})^{\mathrm{h}} \\
+\mathrm{K}_{5} \mathrm{v}^{\mathrm{i}}+\mathrm{K}_{6} \mu^{\mathrm{j}}
\end{gathered}
$$

Even in this reduced form, the equation implicitly states that wear results cannot be predicted from first principles even at one known pressure. There appears to be no advantage at this time in expressing each term as an accurate formula. The proposed formula, however, indicates now to the designer the main parameters which act as separate, additive terms influencing the total amount of wear.

The scanning electron photomicrographs clearly indicate examples where certain terms dominate in the wear process. When TZM pins rubbed against tungsten in run 40 , the hard tungsten particles abraded the molybdenum alloy. When Type 316 stainless steel rubbed against Type 304, stainless steel flowed plastically across the rubbing surfaces like cold butter being spread, indicating that the work-hardening and coefficient-of-friction terms dominated in this wear process.

In a very important paper on wear theory, Archard ${ }^{(21,22)}$ proposed that friction and wear are related in the following way. Friction is the shearing of all "friction-junctions" while wear is the creation and loss of wear fragments created from a certain fraction of the total number of friction junctions. This theory implicitly assumes that all wear fragments are the same size. Actually, the size of the wear fragment increases as the work-hardening exponent increases. Therefore, adhesive wear has been separated into two separate terms: $f_{6}(\mu)$ which indicates the actual number of friction junctions contributing to the creation of wear fragments, and $f_{1}(n)$, which describes the median size of these fragments. 


\section{Material Screening Results}

The results allow certain generalities to be made concerning the behavior of each material class. The material of the pin is used here to establish under which heading the wear behavior of the pin-plate combination is listed. The screening results are reported in terms of a wear coefficient, $\mathrm{cm}^{3} / \mathrm{cm} / \mathrm{kg}$, or "buildup" of the pin, or "galling" of the couple. An example of pin buildup is shown in Figure 20 and of a galled surface in Figure 21 . The wear coefficient involves total sliding distance and this distance is difficult to define for a point in the wear track of a plate. At each revolution, a point in the plate wear track is subjected to sliding for a fraction of the diameter of the pin or, for a point in the exact middle of the plate wear track width, the full pin diameter. Thus, a point near an edge of the wear track width experiences a far smaller sliding distance than a midwidth point would experience. Since a definition of the wear coefficient requires the total sliding distance, the wear coefficient concept cannot be used to describe plate wear. Even the total depth of wear on a plate is a strong function of the pin geometry, not just the pin area, load, and revolutions. The pin-plate combination is best described, then, by what happens to the pin when the combination is tested.

\section{a. Behavior in Liquid Sodium}

The tool steels without exception, showed inadequate wear behavior at $1200^{\circ} \mathrm{F}$ in liquid sodium. At 800 and $1000^{\circ} \mathrm{F}$, the wear characteristics are very near to each other and fair. One alloy of this class gave good results at $800^{\circ} \mathrm{F}$, the Whittaker NM100 alloy pin rubbing against Inconel 718. The wear behavior at $500^{\circ} \mathrm{F}$ appears to be good for all tool steels.

The copper-base alloys running against themselves or against Stellites, stainless steel, or chromium plate showed very poor wear characteristics; but this may very well have been due to the low pin pressures used in these particular tests. Copper alloys rubbing against the materials named above have shown good wear behavior in previous tests by Coffin, (9) but copper is, perhaps, too soluble in sodium to be a good candidate material even when the contact pressures are of the right magnitude to give wear values in the fairly low wear regime.

The molybdenum-base alloys tested were TZM and molybdenum. Tests were run at $1200^{\circ} \mathrm{F}$ and in no case was adequate wear behavior encountered in

\section{LMEC- $70-10$}




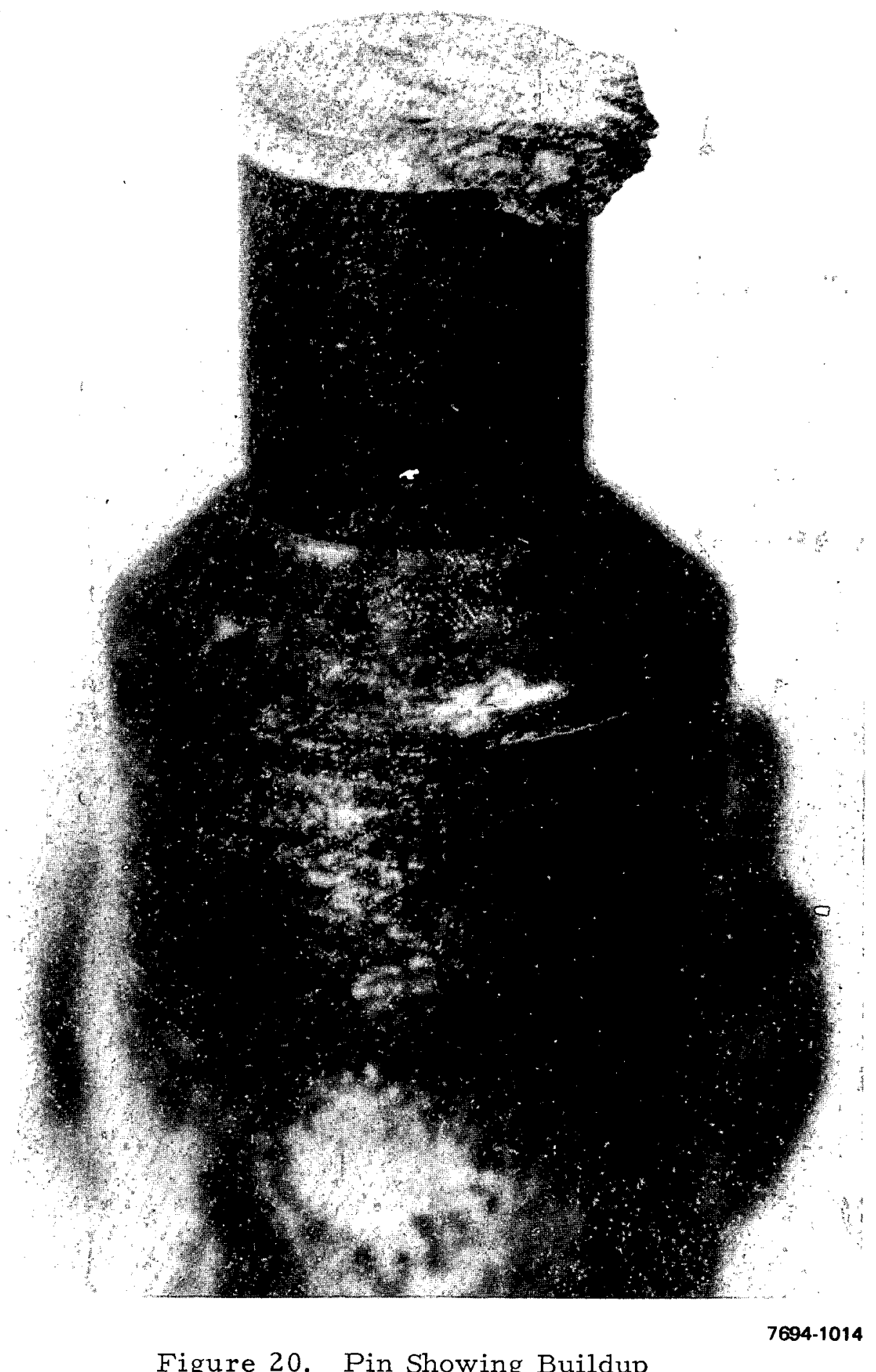

Figure 20. Pin Showing Buildup

LMEC-70- 10

154 


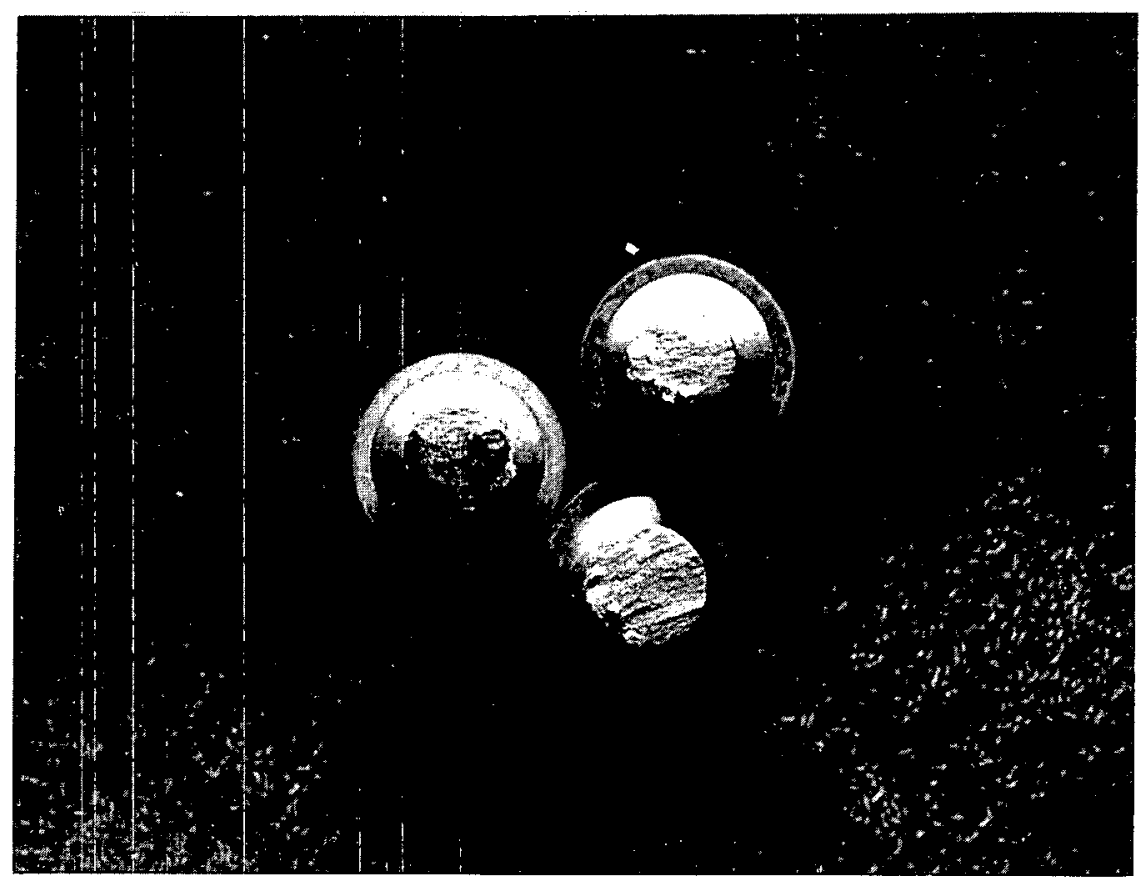

$7694-1022$

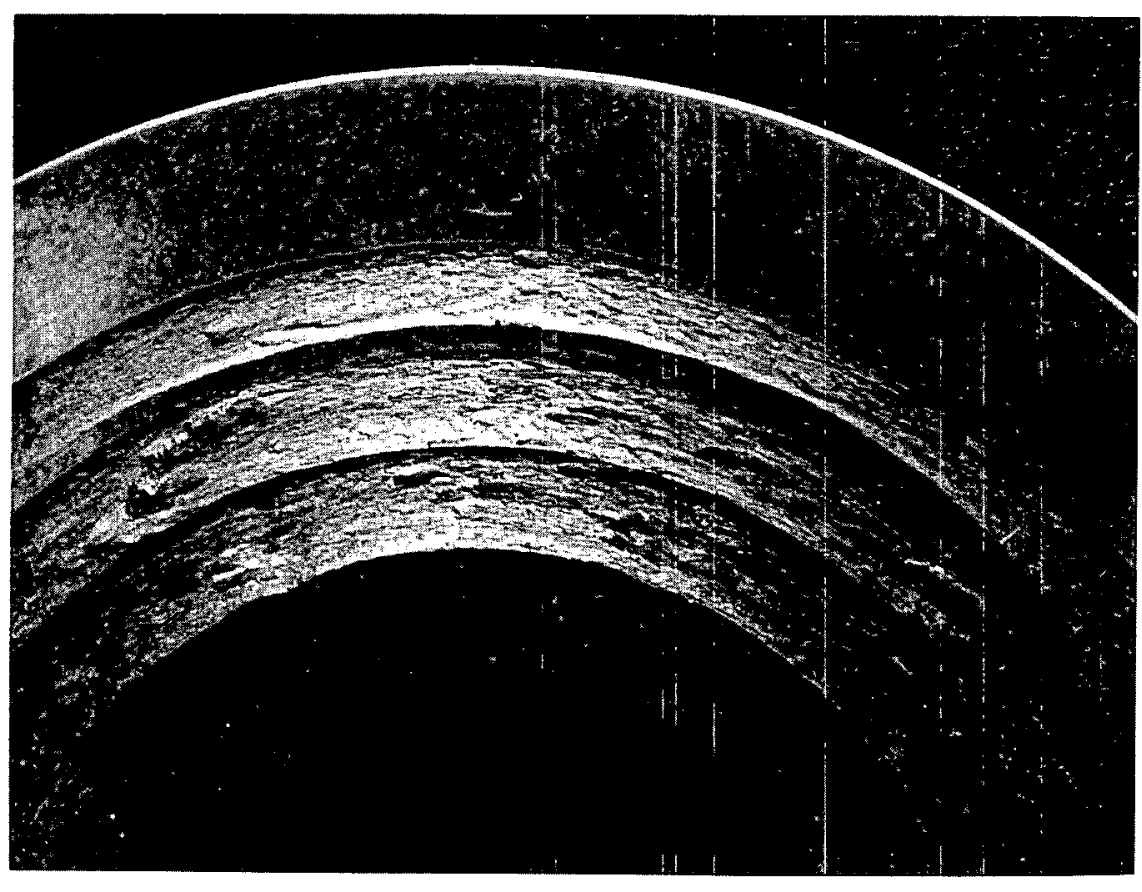

7694-1025

Figure 21. Galled Surfaces

\section{LMEC-70- 10}


liquid sodium, although good wear behavior was experienced in the cases of TZM pins running against Hastelloy C or K-95 plate materials in sodium vapor. Scanning electron photomicrographs of pin surfaces were taken after the run between molybdenum pins and tungsten plate at $128 \mathrm{psi}$. The photomicrographs show that body abrasion (wear by particle plowing) is the dominant wear process on the molybdenum alloy TZM pins that rubbed against a tungsten plate (see Figure 22).

Wear on tungsten pins is shown in Figure 23. This material is very brittle, and evidence of this brittleness is present in the photograph. This property probably eliminates tungsten as a candidate material.

The nickel-base alloys did not show particularly good wear behavior when rubbing against themselves at test temperatures above $500^{\circ} \mathrm{F}$. Scanning electron microscope photomicrographs showed that smearing often occurred during the rubbing (see Figure 24) and, in the case of Hastelloy C, a "smooth lowland, roughened raised furrow" pattern was noted (see Figure 25).

The cobalt alloys were just slightly better than the nickel alloys at $1200^{\circ} \mathrm{F}$ (see Figure 26) except that hard-facing-type alloys running against bonded carbides (e.g. : Stellite 1 against K-95) occasionally resulted in very low wear coefficients. In the single $500^{\circ} \mathrm{F}$ test involving cobalt-alloy pins, the wear of the cobalt alloy, Stellite 1016, against a stainless plate had a good, low value.

In general, the most consistently good wear results associated with a relatively available alloy in the $1200^{\circ} \mathrm{F}$ sodium runs were those for Star $\mathrm{J}$, the cast form of the hard-facing alloy, Stellite 1016.

The austenitic Type 300 series stainless-steel pins underwent relatively high wear at $1200^{\circ} \mathrm{F}$. Tests of Type 304 pins against Stellite 1016 pins gave the wear coefficients as a function of temperature shown in Figure 27.

The precipitation hardening stainless steels showed poor wear characteristics at $1200^{\circ} \mathrm{F}$. No tests in liquid sodium were performed at lower temperatures with these pins.

The cemented carbides and the difficult-to-obtain metal-ceramic composite, LT-2, showed the least wear in $1200^{\circ} \mathrm{F}$ sodium (this latter material contains $25 \%$ chromium, $60 \%$ tungsten, and $\left.15 \% \mathrm{Al}_{2} \mathrm{O}_{3}\right)$. This LT-2 from the Stellite Division of Cabot Corporation appears to be a promising material for sliding contact applications in sodium.

LMEC-70- 10

156 


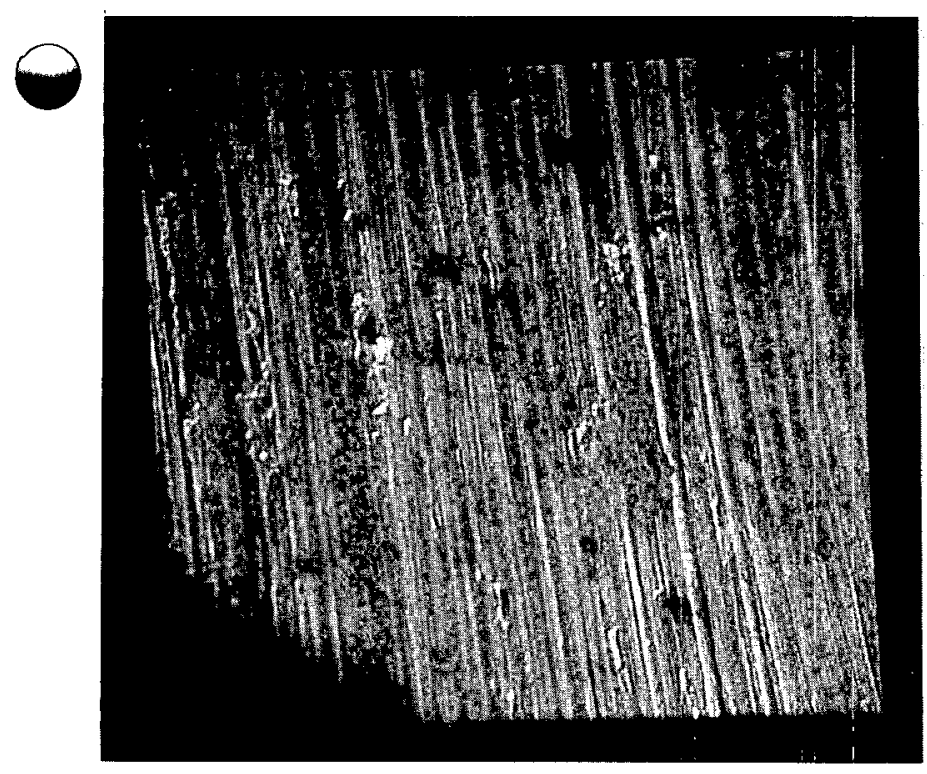

a. $75 x$

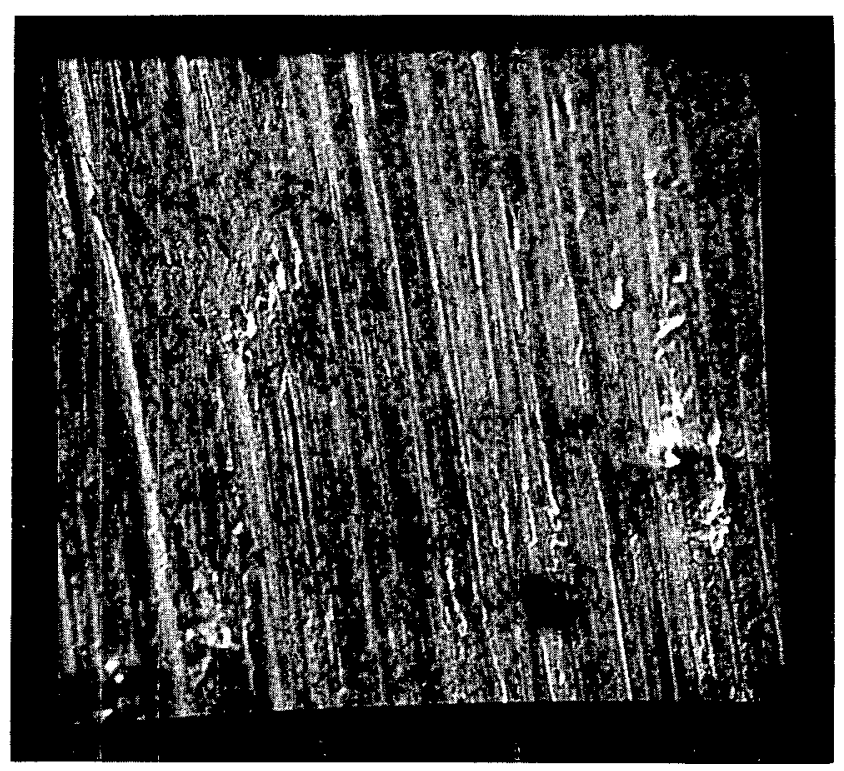

b. $150 x$

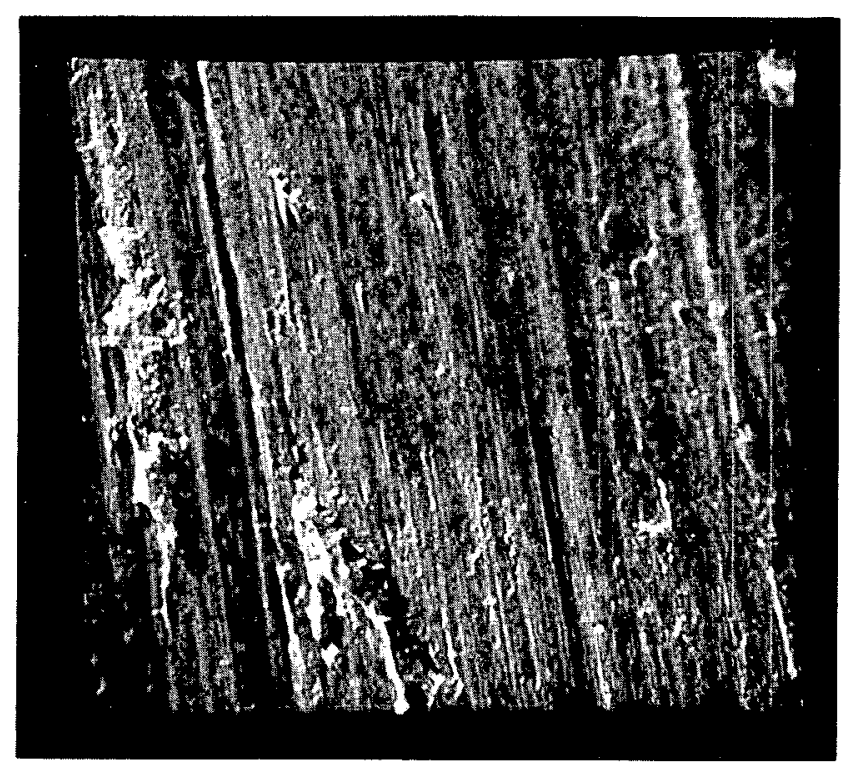

c. $750 \mathrm{X}$

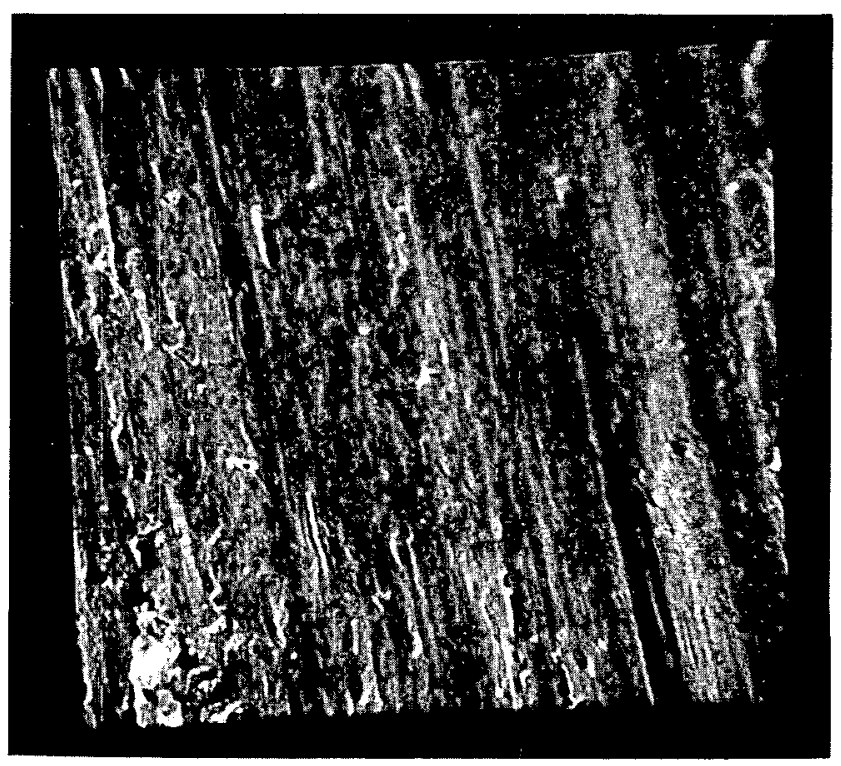

d. $1500 \mathrm{X}$

Figure 22. Scanning Electron Microscope Photographs TZM Molybdenum Alloy Pin after Sliding Contact Against Tungsten Plate at $130 \mathrm{psi}$ in $1200^{\circ} \mathrm{F}$ Liquid Sodium (Test 40) 


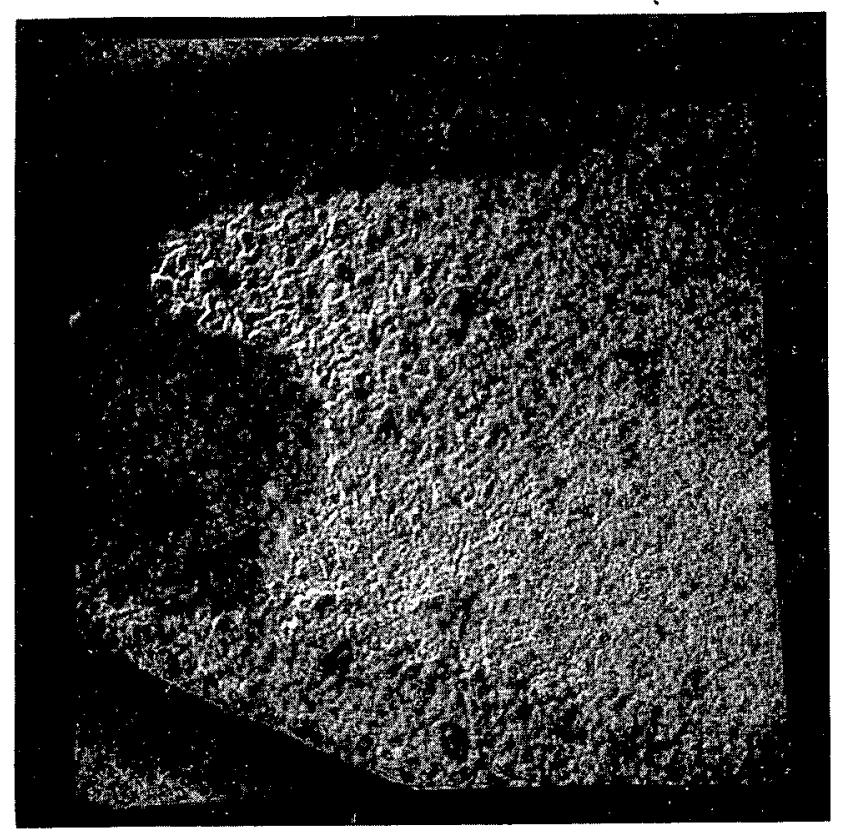

a. $150 x$

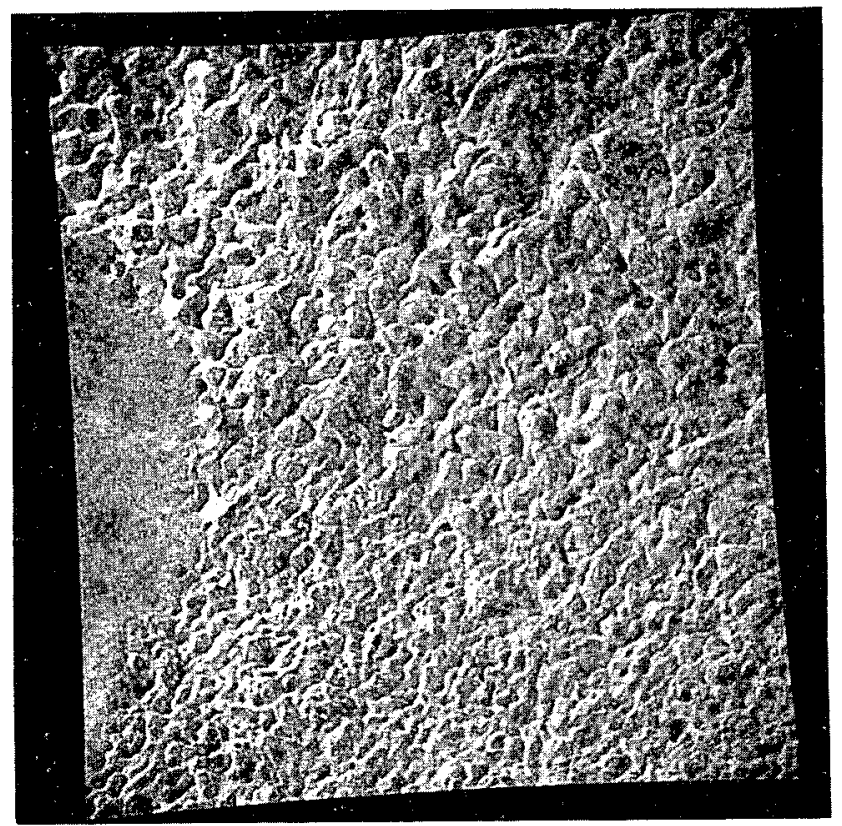

b. $375 x$

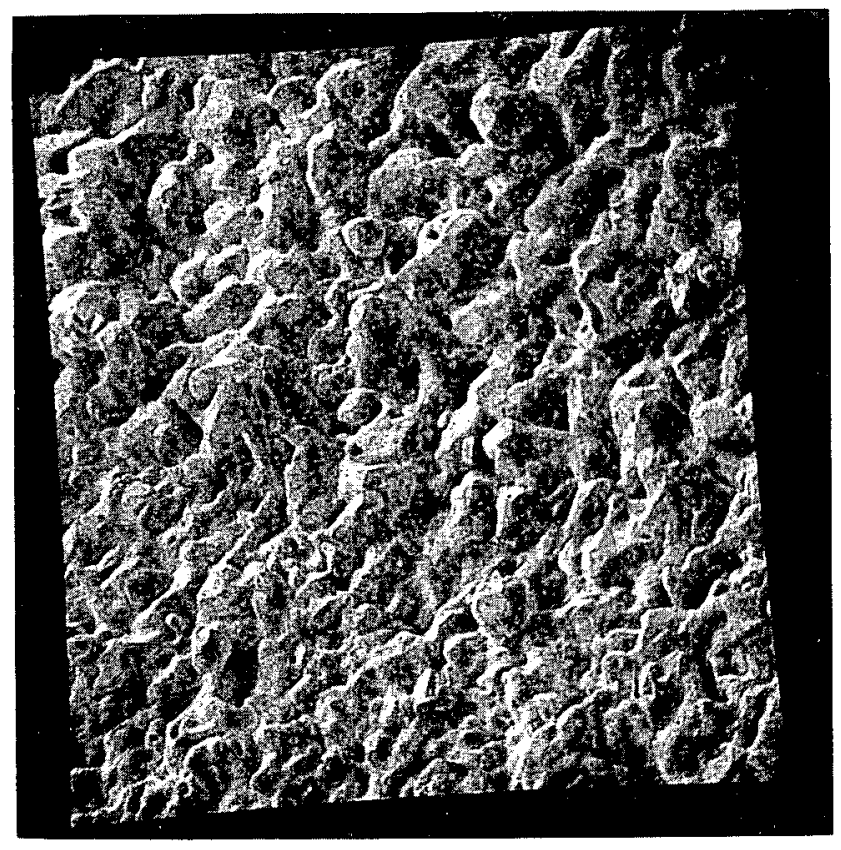

c. $750 \mathrm{X}$

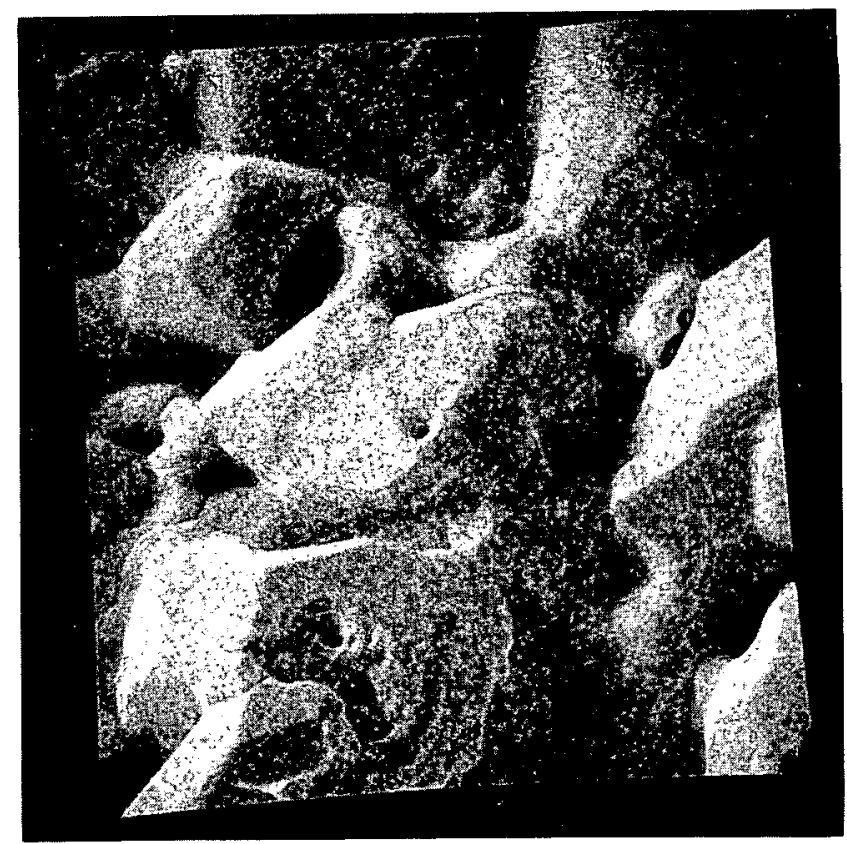

d. $3750 \mathrm{X}$

Figure 23. Scanning Electron Microscope Photographs Tungsten Pin after Sliding Contact Against Hastelloy C Plate at $119 \mathrm{psi}$ in $1200^{\circ} \mathrm{F}$ Sodium Vapor (Test 98) 


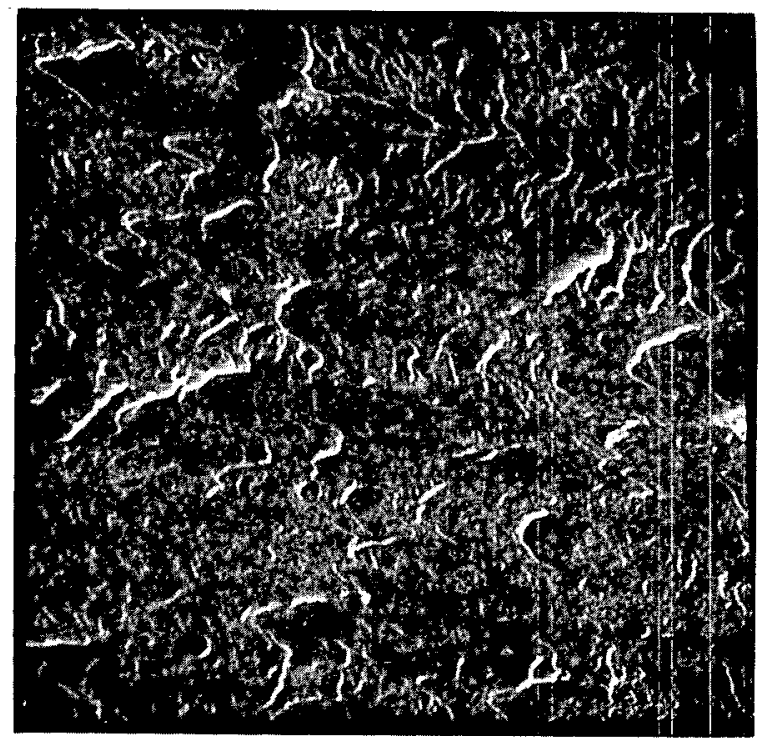

a. $750 \mathrm{x}$

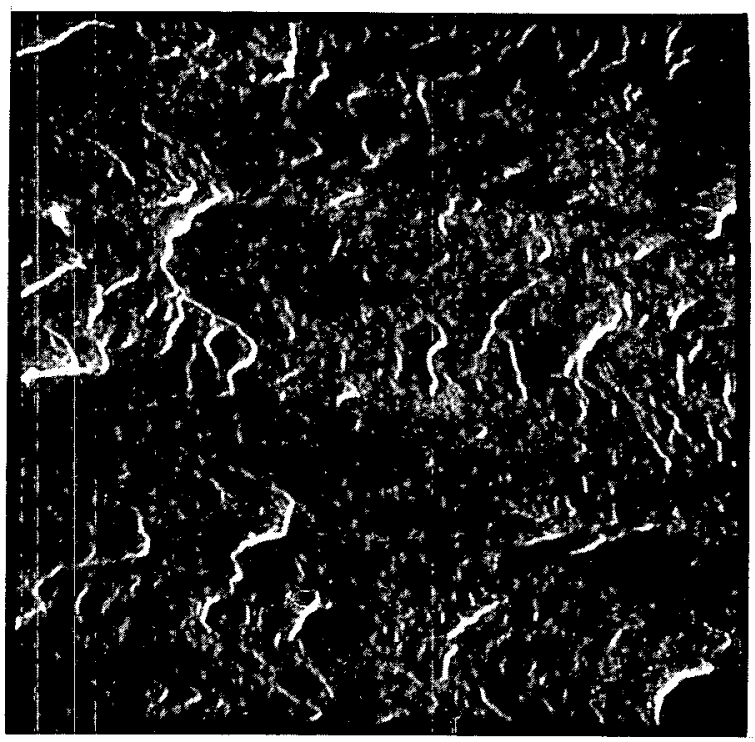

b. $1500 x$

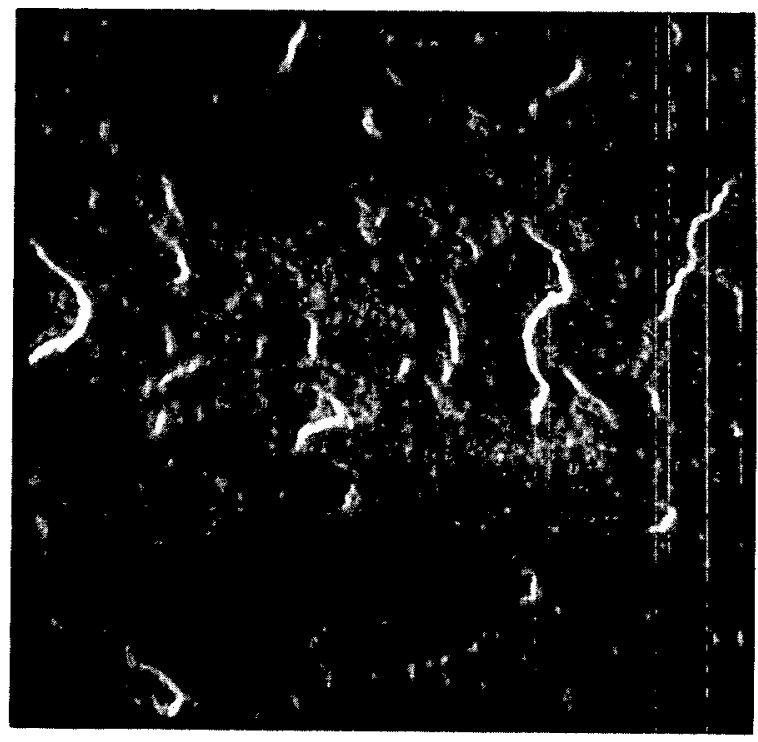

c. $3750 \mathrm{X}$

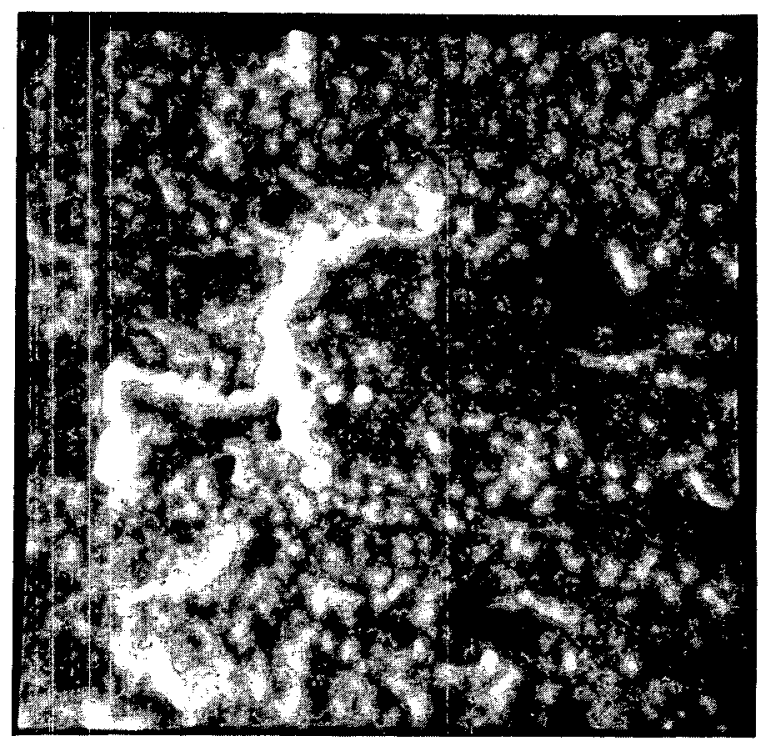

d. $7500 \mathrm{x}$

Figure 24. Scanning Electron Microscope Photographs Inconel 718 Pin after Sliding Contact Against

(Udimet 630 Plate at 83 psi in $1200^{\circ} \mathrm{F}$ Liquid Sodium (Test 368) 


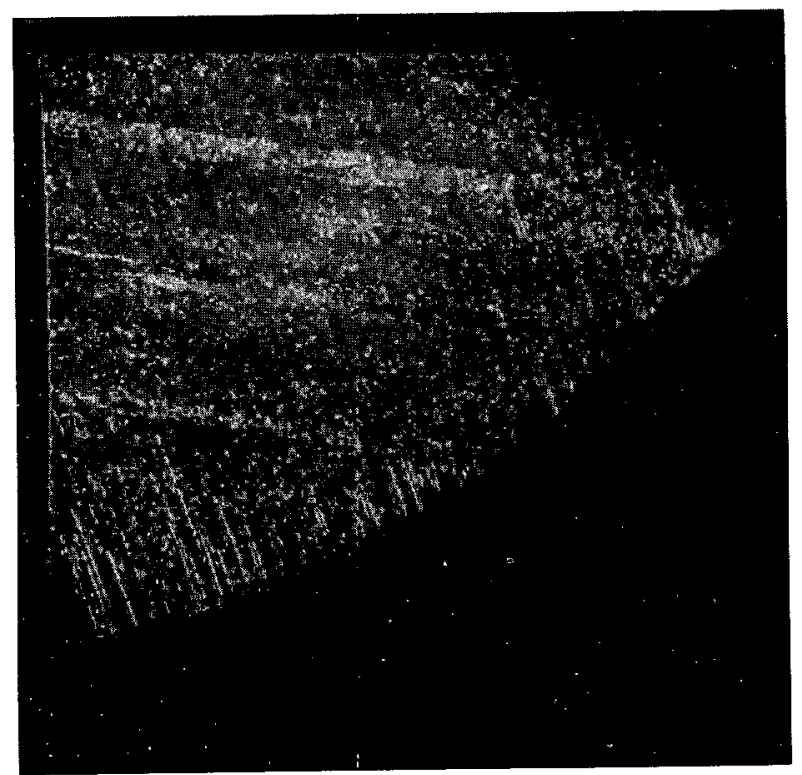

a. $75 x$

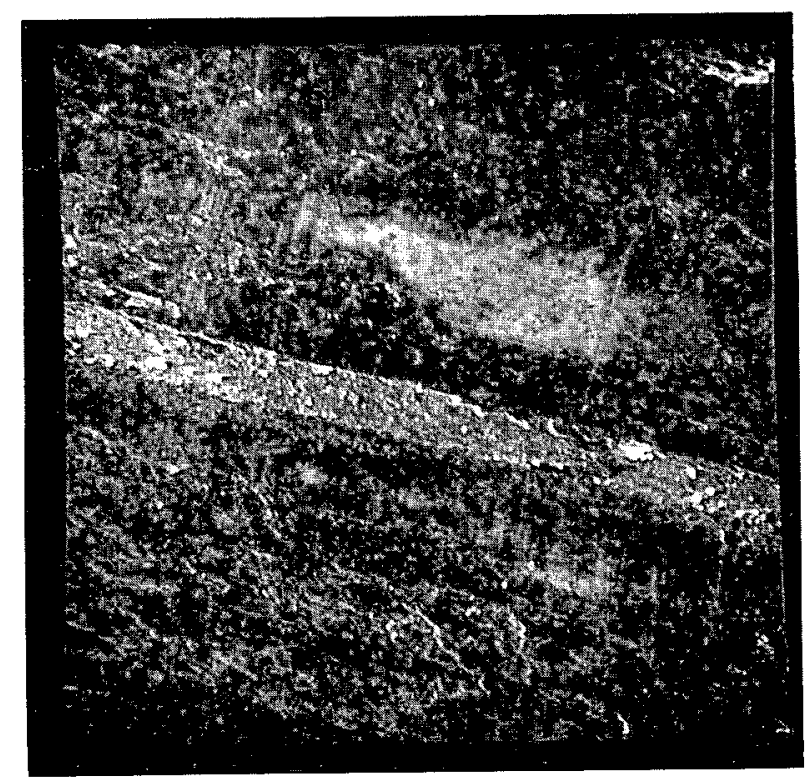

b. $375 x$

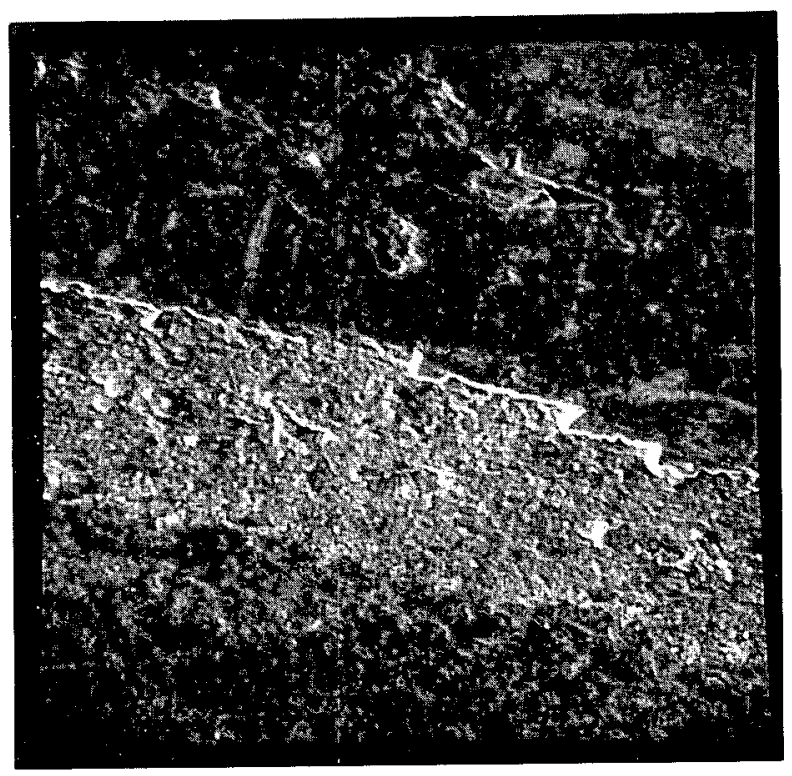

c. $1500 x$

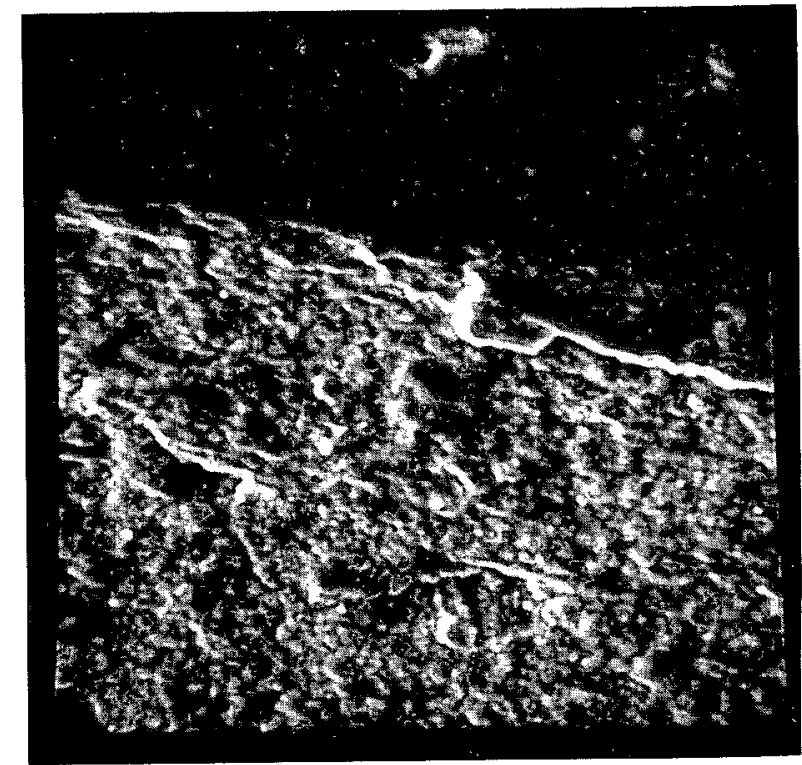

d. $3750 x$

Figure 25. Scanning Electron Microscope Photographs Hastelloy C Pin after Sliding Contact Against

Hastelloy C Plate at $101 \mathrm{psi}$ in $1050^{\circ} \mathrm{F}$

Liquid Sodium (Test 378)

LMEC- 70- 10

160 


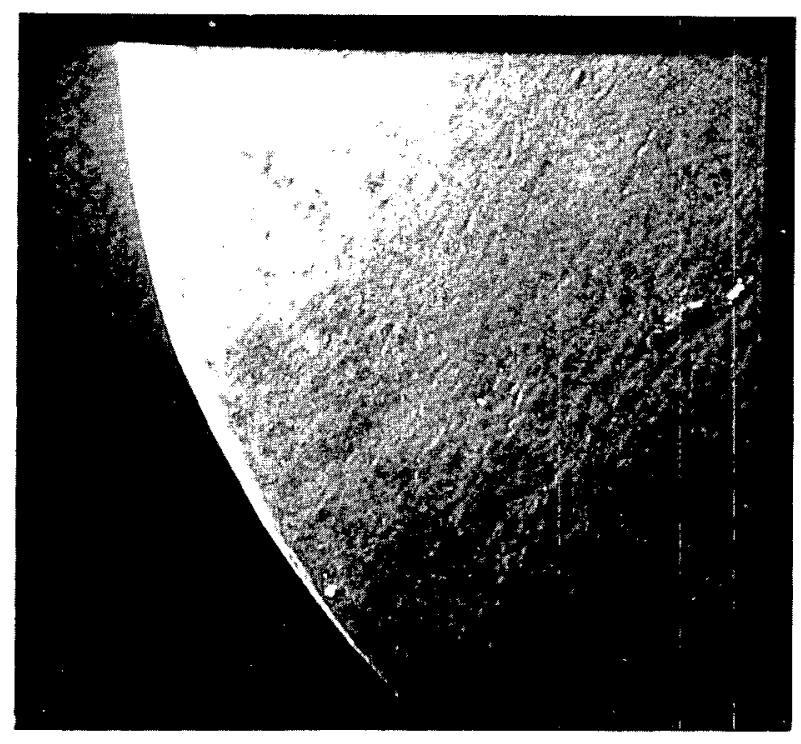

a. $75 x$

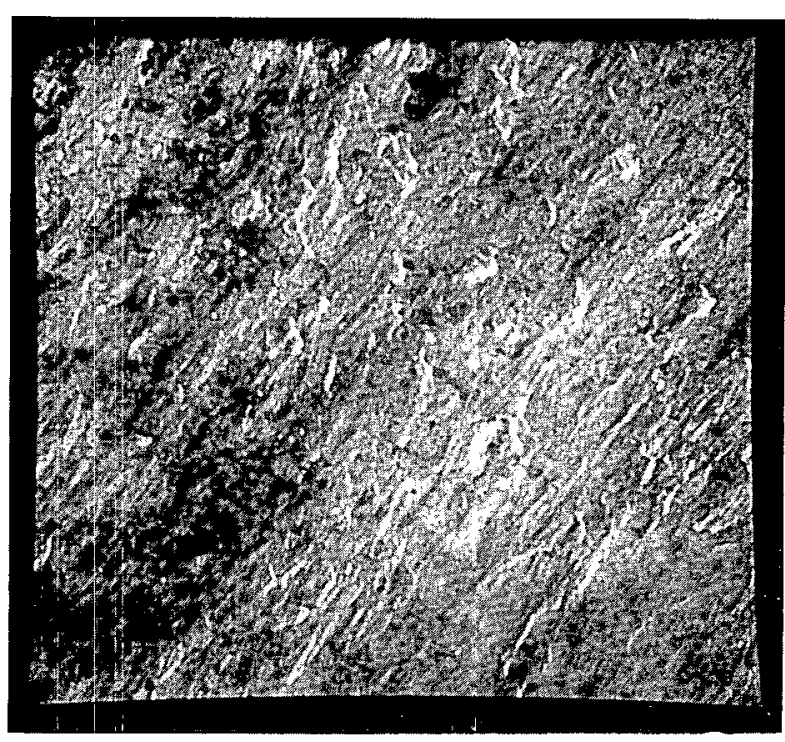

b. $375 X$

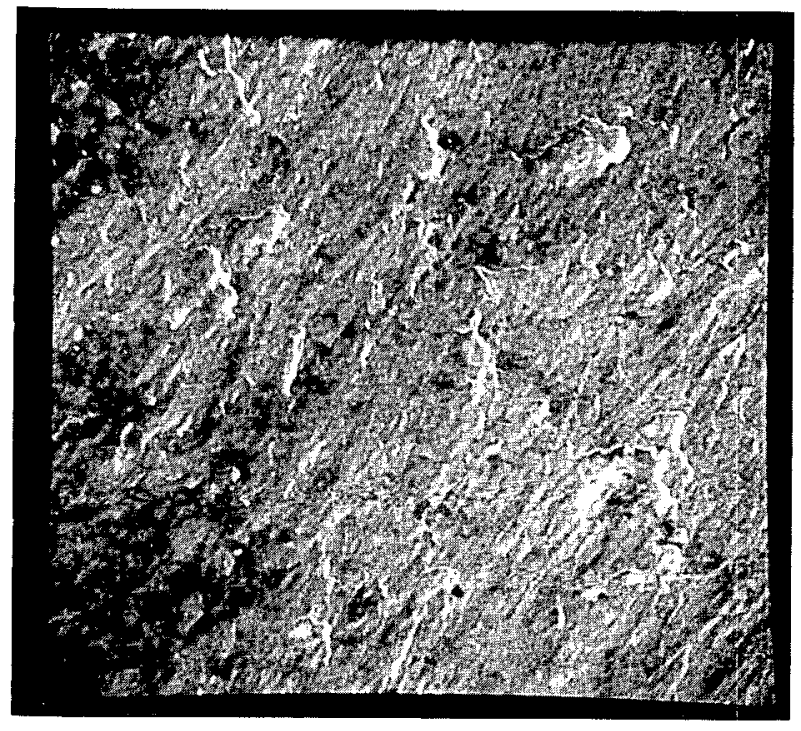

c. $750 \mathrm{X}$

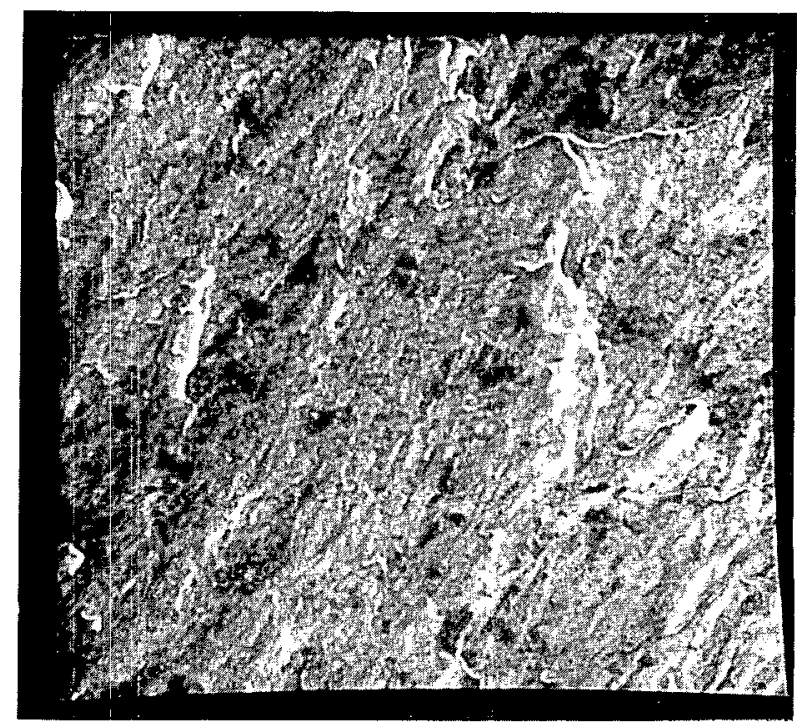

d. $1500 \mathrm{X}$

Figure 26. Scanning Electron Microscope Photographs -

Stellite 1 Pin after Sliding Contact Against

Stellite $6 \mathrm{~B}$ Plate at 130 psi in $1200^{\circ} \mathrm{F}$

Liquid Sodium (Test 62)

LMEC - 70- 10

161 


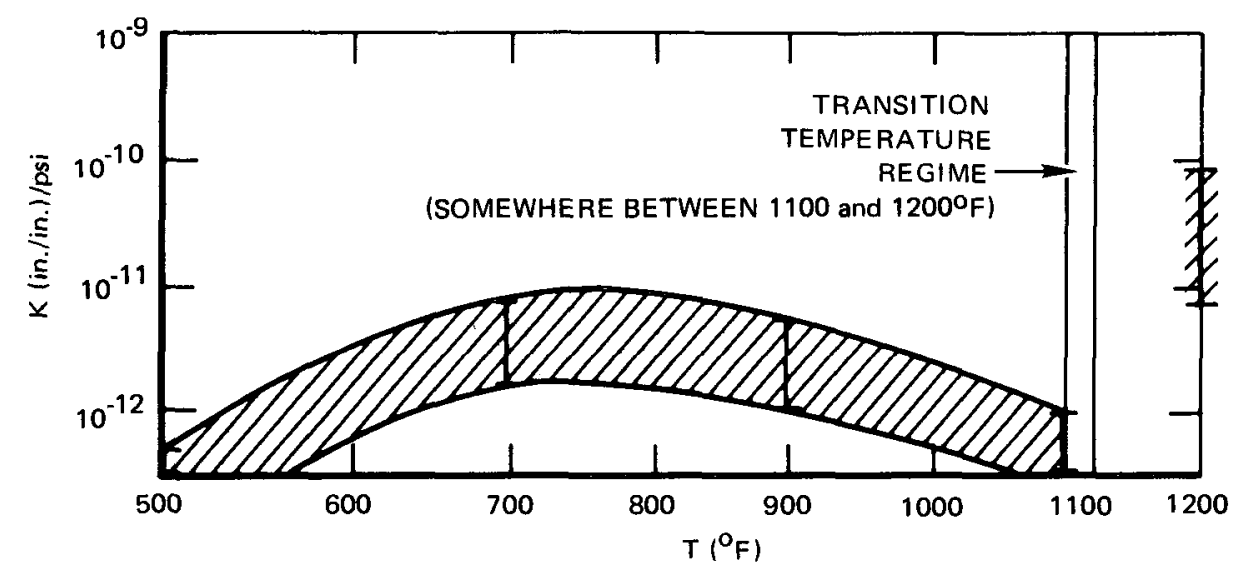

$7693-4740$

Figure 27. Wear Coefficient of Type 304 SS Rubbing on Stellite 1016 as a Function of Temperature

A somewhat similar material, LT-1, fell apart in sodium, though this may have been due to sintering problems. The relatively small amount of $\mathrm{Al}_{2} \mathrm{O}_{3}$ in the LT-2, 15\%, might have reacted with the sodium, but the specimens appeared to be in excellent shape after the runs.

The tool-steel pins were tested at 800 and $500^{\circ} \mathrm{F}$ in sodium vapor and did not suffer severe wear. The refractory metals were tested at $1200^{\circ} \mathrm{F}$ and gave erratic results with TZM showing up much better in sodium vapor than it did in the liquid. The nickel-base alloys were very good at $500^{\circ} \mathrm{F}$, but were occasionally fair and generally poor at $1200^{\circ} \mathrm{F}$. The "fair" results were Inconel 718 pins against molybdenum alloy plate or against $\mathrm{K}-95$ cemented carbide, and Udimet 630 pins against itself or against Hastelloy $\mathrm{C}$ plate. The cobalt-alloy pins were all run at $1200^{\circ} \mathrm{F}$ in the vapor tests except for one run at $500^{\circ} \mathrm{F}$ involving Stellite 1016 pins against Type 304 stainless-steel plate. These $500^{\circ} \mathrm{F}$ test pins had excellent wear behavior. In the $1200^{\circ} \mathrm{F}$ tests, cobalt alloys running against themselves usually exhibited unacceptable behavior. Stellite 3 showed fair behavior against each plate material it was rubbed against, and may be considered the best of the cobalt alloys tested in sodium vapor, although it was not the best in liquid sodium. Stellite 1016 exhibited wear behavior almost as good as that of Stellite 3 in the vapor tests. One run was made with austenitic stainlesssteel pins in sodium vapor; this was Type 304 stainless-steel pins against a Stellite 1016 plate at $500^{\circ} \mathrm{F}$, and these pins exhibited excellent wear characteristics. In general, the cemented carbide pins wore about the same as the better 
cobalt pins in vapor at $1200^{\circ} \mathrm{F}$, except that $\mathrm{K}-95$ against itself and against Hastelloy $C$ exhibited extremely good wear resistance. The tungsten-chromiumalumina ceramic, LT-2, that showed excellent wear resistance in liquid sodium, has not yet been tested in vapor.

3. Hardness Changes due to Exposures

The hardness of the test materials was occasionally affected by exposure to liquid sodium at $1200^{\circ} \mathrm{F}$. Table 11 gives examples for all the materials that were affected by the exposure. Such effects were very much reflected in the wear results of those alloys that dropped a significant number of hardness points.

TABLE 11

HARDNESS CHANGES AFTER EXPOSURE TO TEST ENVIRONMENT

\begin{tabular}{|c|c|c|c|c|}
\hline \multirow[b]{2}{*}{ Material } & \multicolumn{2}{|c|}{ Exposure } & \multirow[b]{2}{*}{$\begin{array}{l}\text { Pretest } \\
\text { Hardness }\end{array}$} & \multirow[b]{2}{*}{$\begin{array}{l}\text { Hardness } \\
\text { Change }\end{array}$} \\
\hline & $\begin{array}{l}\text { Time } \\
\text { (hours) }\end{array}$ & Temperature & & \\
\hline Ampco 18-13 & 200 & 482 & $\mathrm{R}_{A} 51-53$ & $+4 \mathrm{R}_{\mathrm{A}}$ \\
\hline AISI Ml & 2.8 & 650 & $R_{C} 47-49$ & $-14 R_{C}$ \\
\hline AISI M15 & 4.6 & 650 & $R_{C} 50-52$ & $-12 R_{C}$ \\
\hline AISI T 1 & 2.8 & 650 & $R_{C} 54-56$ & $-16 R_{C}$ \\
\hline AISI T 15 & 2.8 & 650 & $R_{C} 50-52$ & $-14{ }^{R} \mathrm{C}$ \\
\hline Colmonoy 6 & 200 & 650 & $R_{A} 58-60$ & $-26 \mathrm{R}_{\mathrm{A}}$ \\
\hline Hard Chrome Plate & 200 & 452 & $R_{C} 60-63$ & $-14 R_{C}$ \\
\hline Hastelloy C & 200 & 650 & $R_{A} 51-53$ & $+2 R_{A}$ \\
\hline $\operatorname{Rex} 49$ & 200 & 427 & $R_{C} 50-58$ & $+7 \mathrm{R}_{\mathrm{C}}$ \\
\hline SS $17-4 \mathrm{PH}$ & 200 & 650 & $R_{C} 42-43$ & $-16 R_{C}$ \\
\hline Stellite 273 & 200 & 650 & $\mathrm{R}_{\mathrm{A}} 56-58$ & $+8 \mathrm{R}_{\mathrm{A}}$ \\
\hline
\end{tabular}

*Hardness measurements at room temperature.

LMEC - 70- 10 


\section{Observed Pressure Effects}

The effects of pressure on the wear of stainless-steel pins were also studied. Tests currently being performed at LMEC gave wear results at high pressures while these tests were performed in the 120-psi range. Figure 28 gives the wear coefficient of austenitic steel pins running against themselves, in $1200^{\circ} \mathrm{F}$ liquid sodium, as a function of contact pressure. Scanning electron microphotographs of stainless-steel pins that have rubbed at 125, 1000, and 5000 psi are shown in Figure 29. The photographs show differences in the smearing behavior of the stainless steel.

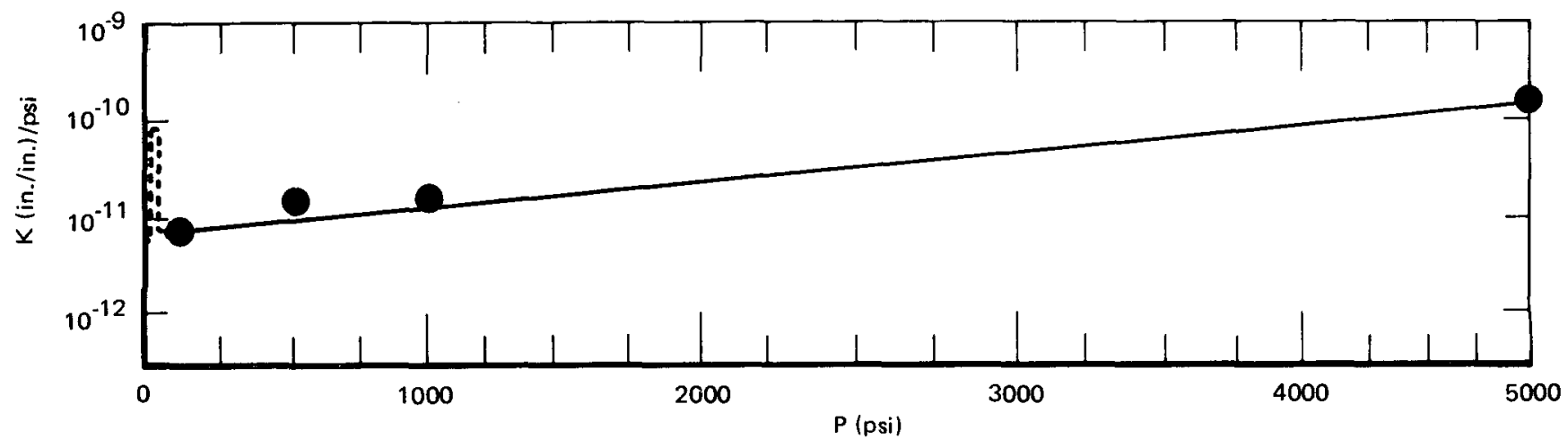

7693-4741

Figure 28. Wear Coefficient of Austenitic Stainless Steel Rubbing on Itself in $1200^{\circ} \mathrm{F}$ Sodium as a Function of Contact Pressure

In most of the runs performed in liquid sodium, contact pressures were about 125 psi. Certain tests were performed at 30 psi which could well correspond to the high wear regime noted at low pressures in other environments. $(19,20)$ The ratio of tests that exhibited buildup and galling to the total number of tests can be calculated from the presented data for the low-pressure runs (<50 psi) and normal pressure runs ( 125 psi). For the just-under 50 pins that were run at low pressures, $45 \%$ showed buildup or galling while, for the approximately 900 runs in the 125-psi range, $12 \%$ showed buildup or galling.

\section{Coefficient of Sliding Friction Effects}

The results of these tests show that the increases in the values of sliding coefficient of friction may prove to be more of a problem to the designer than the wear itself. A typical sliding friction curve generated in these tests is shown in Figure 30. 


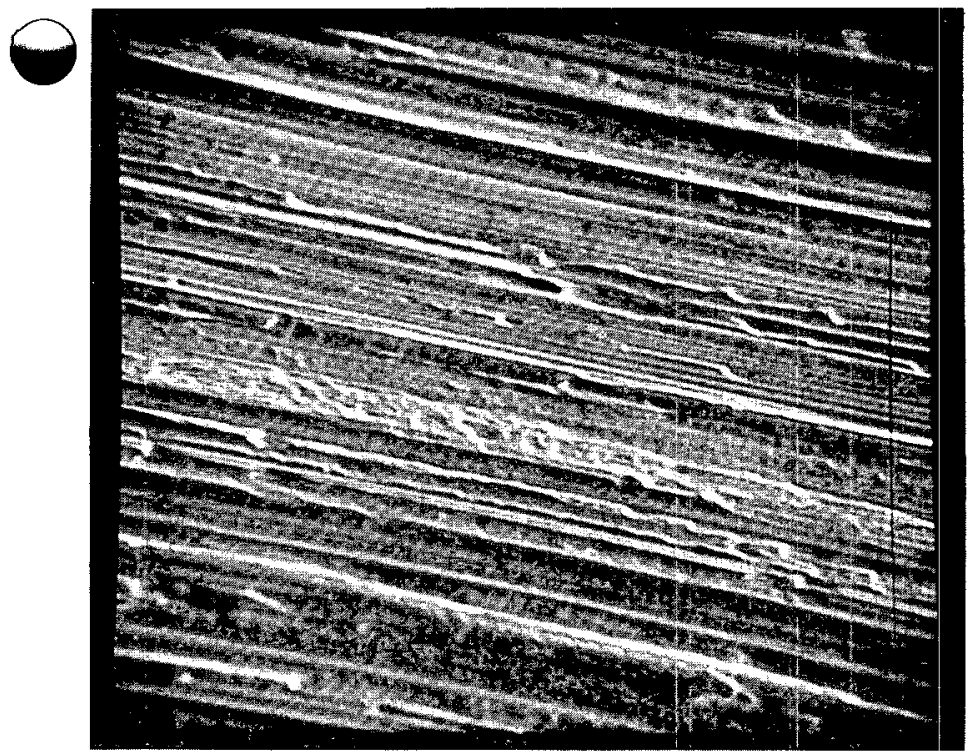

a. As-ground, pretest specimen,

Type 304 SS (20\% c.w.) pin, $1500 \mathrm{X}$

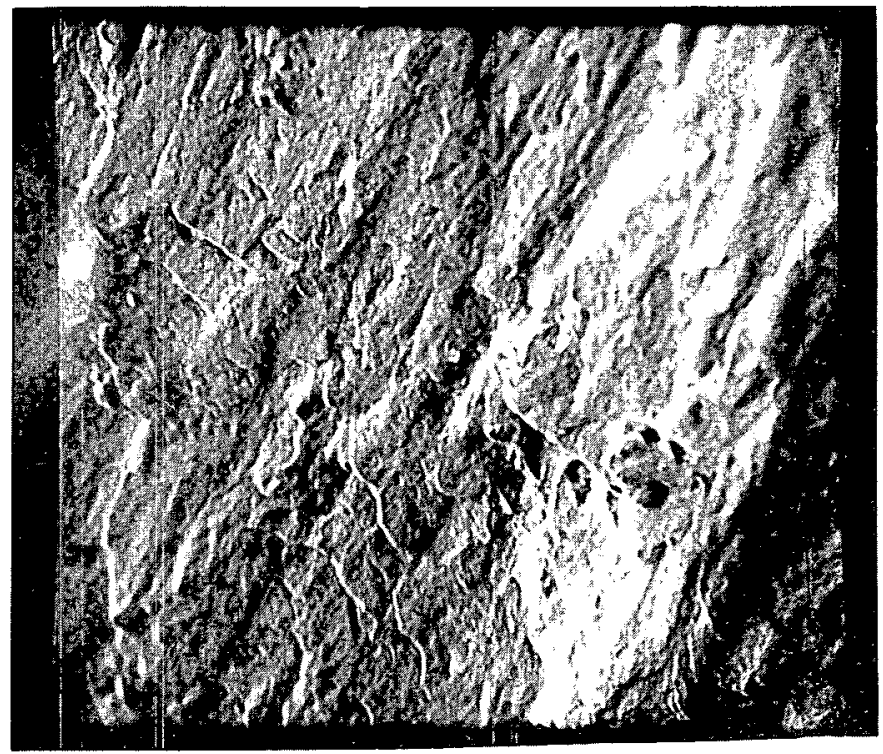

b. Type 316 SS $(20 \%$ c.w. $)$ pin, rubbed against Type 304, 375X

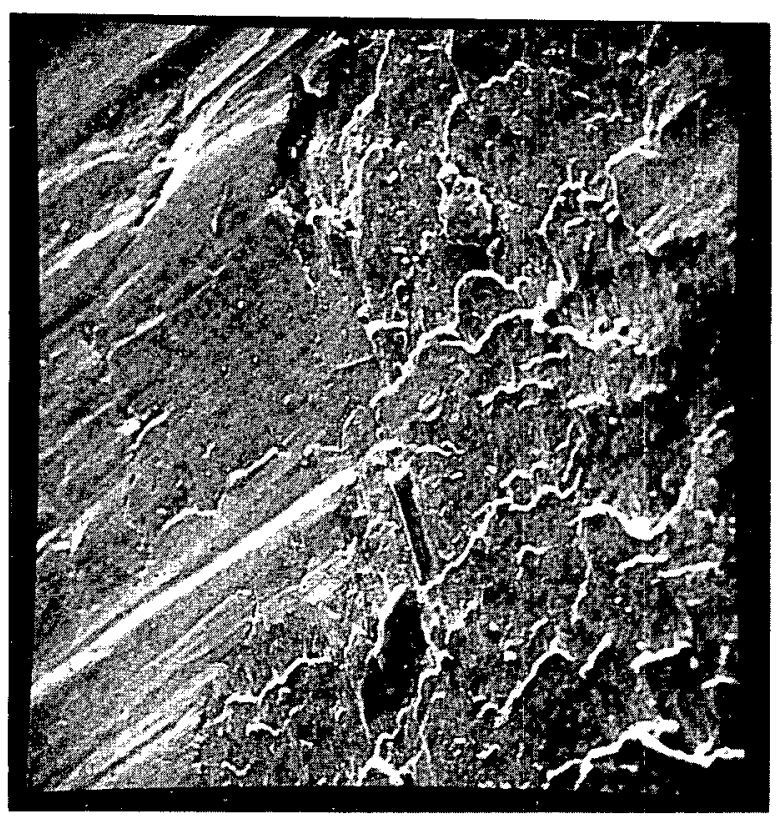

c. 1000-psi contact pressure, Type 316 SS (20\% c.w.) pin, rubbed against Type 304 , $375 X$

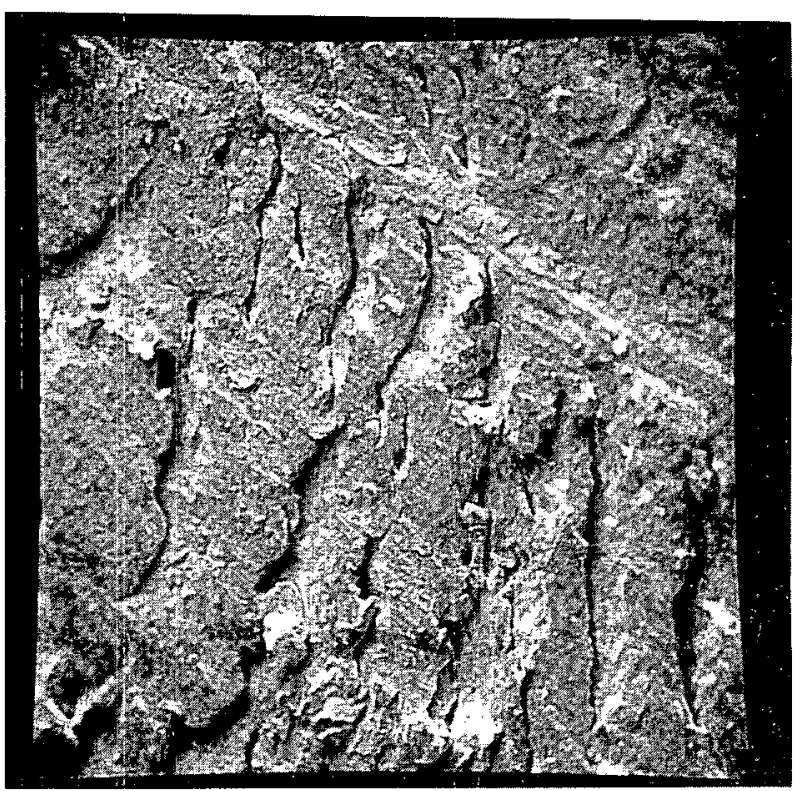

d. 5000-psi contact pressure, Type 316 SS (20\% c.w.) pin, rubbed against Type 304 , $375 X$

Figure 29. Scanning Electron Microscope Photographs of Type 300 Series Stainless-Steel Pins Showing Results of Sliding Contact in $1200^{\circ} \mathrm{F}$ Sodium as a Function of Contact Pressure 


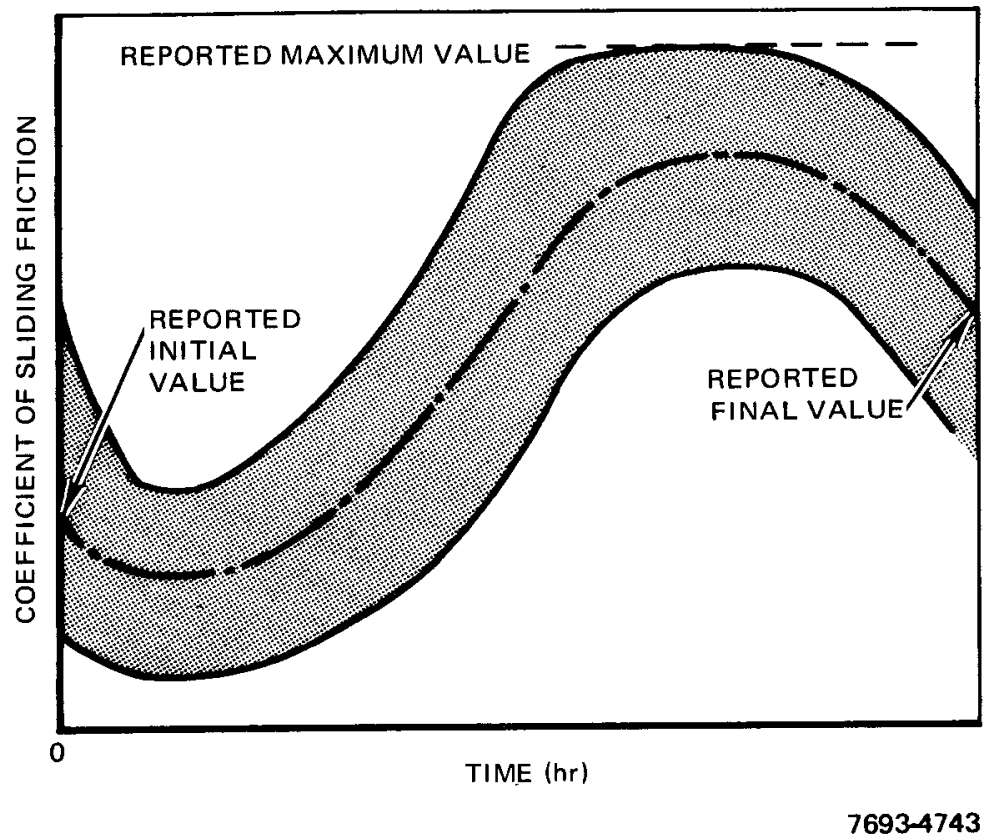

Figure 30. General Shape of Coefficient of Sliding Friction Data as a Function of Time

LMEC-70- 10 


\section{FUTURE WORK}

Material wear behavior tests in static and sliding contact in sodium liquid and vapor will be continued. First priority will be given to tests in direct support of the Fast Flux Test Facility (FFTF). These tests will simulate basic features of certain in-core components with (contacting) surfaces in static and sliding contact. Examples are control rod and fuel handling machine mechanisms, ducts, duct spacer pads, grid plates, nozzles, shafts, cladding, and wire wrap. Anticipated modes of motion will be duplicated, as applicable, including unidirectional and reversed sliding on flat surfaces, and reciprocating axial or reciprocating rotational motions on cyclindrical surfaces, and certain combinations thereof. Materials of principal interest involve Types 304 and 316 stainless steel and Inconel 718. Temperatures of interest range from 400 to $1200^{\circ} \mathrm{F}$.

Second priority will be given to obtaining additional basic wear data. Parameters such as contact pressure, temperature, sliding velocity, total distance traversed, and sodium environment will be varied to determine their effects on FFTF material combinations of interest. Particular emphasis will be placed on sudden changes in wear behavior. For example, transition-temperature-type behavior is noted in wear studies, and in the case of alloys that contain significant amounts of chromium this transition temperature appears to be between 900 and $1200^{\circ} \mathrm{F}$. Experiments to delineate the transition temperature as a function of oxygen content of sodium and the cover gas are required. Also, the effects of load on wear in air and several other environmental media indicate a transition behavior where loads below $2 \mathrm{lb}$, but above $0.2 \mathrm{lb}$, appear to give a very high volumetric wear per unit load. This effect needs to be studied in a sodium environment.

Other areas of future interest include:

1) The wear effects of pure sodium monoxide, supersaturated sodium liquid, and of sodium deposits with high oxide content.

2) Effects of twisting contact on adhesion.

3) Effects of deformed surfaces on adhesion. 
Effects of long-term exposure (in some cases, up to $30 \mathrm{yr}$ ) in a typical LMFBR environment must also be evaluated. Depending on the material and its position in the coolant system, with respect to temperature and concentration gradients, there may be depletion or deposition of constituents affecting frictional and wear behavior. Wear tests should be performed using contacting materials with surface compositions duplicating those expected after long-term exposure to sodium.

Basic wear data are needed involving rolling contact and fretting corrosion in sodium, and such tests should be started as soon as possible. 


\section{REFERENCES}

1. W. J. Freede, et al., "Static and Sliding Contact Behavior of Materials in Sodium Environments at Elevated Temperatures, "NAA-SR-12446 (September 1957)

2. J. K. Balkwill, "Mechanical Elements Operating in Sodium and Other Alkali Metals, Volume I, Literature Survey, "LMEC-68-5 (December 1968)

3. C. C. Addison and M. G. Barker, "Reactions of Liquia' Sodium with Transition Metal Oxides, II. Reduction of Chromium Trioxides to a Ternary Oxide, Chromium (IV), "J. Chem. Soc, London (October 1965)

4. C. C. Addison, M. G. Barker, and R. J. Pulham, "Reactions of Liquid Sodium with Transition-Metal Oxides, I. The Dioxides of Molybdenum, Tungsten, and Uranium," J. Chem. Soc, London, 4483 (1965)

5. H. Kessler, A. Hatterer, and A. Herold, "Action of Alkali Metal Vapours on the Trioxides of Molybdenum and Tungsten, "The Alkali Metals, The Chemical Society, London (1967)

6. M. J. Wallace, "Summary Report of Potential Liquid Metal Bearing Materials for SNAP-50/SPUR Pumps, "PWAC-468 (October 1965)

7. R. Kieffer, "Theoretical Aspects of Sintering of Carbides, "Physics of Powder Metallurgy (McGraw-Hill Book Co., N. Y., 1951)

8. W. P. Sykes, "Cemented Tungsten Carbide Alloys, "Trans. AIME, Vol 128, pp 76-89 (1938)

9. L. F. Coffin, Jr., "A Note on Cemented Tungsten Carbide as a Bearing Material, "KAPL-M-LFC-3 (July 1952)

10. J. W. Kissel, W. A. Glaeser, and C. M. Allen, "Frictional Behavior of Sodium-Lubricated Materials in a Controlled High Temperature Environment, "ASME Symposium (March 1961)

11. P. H. Stahlhuth and R. Trippet, "Liquid Metal Bearing Performance in Laminar and Turbulent Regions, "Trans. ASLE, Vol 5, p 427 (1962)

12. E. B. Arwas, "Topical Report on Turbulent Lubrication, "TID-21992 (November 1964)

13. E. B. Arwas, "Effect of Film Rupture on Journal Bearing Load Capacity and Attitude Angle," MTI-64-TR-68, Rev l (January 1965)

14. H. G. Elrod, Jr., et al., "A Theory for Turbulent Fluid Films and its Application to Bearings," NYO-3363-2 (March 1965) 
15. H. G. Allen, et al., "Sodium Pump Development and Pump Test Facility," WCAP-2347 (August 1963)

16. C. E. Anthony, et al., "Large Sodium Pump Design Study," WARD-3762-1 (November 1967)

17. T. E. Tallian, et al., "Lubricant Films in Rolling Contact of Rough Surfaces, "Trans. ASLE, Vol 7, p 109 (1964)

18. W. J. Greenert and M. R. Gross, "Basic Information on the Bearing Properties of Various Materials in Liquid Metals, "EES Report 090014A (February 1954)

19. E. F. Finkin, "What Happens When Parts Wear," Machine Design (March 19, 1970)

20. F. P. Bowden and D. Tabor, "The Nature of Metallic Wear," The Friction and Lubrication of Solids (Clarendon Press, Oxford, 1950) pp 291-293

21. D. Tabor, "Friction and Wear" Proceedings International Symposium on Lubrication and Wear, Edited by D. Muster and B. Sternlicht (McCutchan Publishing Corp., Berkely, Calif., 1965)

22. J, F. Archard., "Wear," Interdisciplinary Approach to Friction and Wear, Proc of NASA-sponsored symposium, November 28-30, 1967, San Antonio, Texas, NASA SP-181 (Office of Technology Utilization, NASA, Washington, D. C. , 1968)

23. E. Rabinowicz, Friction and Wear of Materials (John Wiley and Sons, Inc., N. Y., 1965)

24. E. S. Sowa, K. C. Tsao, C. Fiala, and C. J. Divona, "Some Observations on Phenomena Affecting Wear of Bearing Materials in Sliding Contact in Sodium and Argon at Temperatures up to $1200^{\circ} \mathrm{F}$, "ANL-758C (July 1969) 


\section{BIBLIOGRAPHY}

LMEC-68-5, "Mechanical Elements Operating in Sodium and other Alkali Metal, Volume 1, Literature Survey, "by J. K. Balkwill, provides a review of the literature prior to the summer of 1968 and the reader is referred to this report for a briefing on much of the work on friction and wear of materials in sodium. An abstract of the Balkwill report is given below. Reports issued subsequently, as well as several reports which were not discussed in the Balkwill report, may also be of interest and abstracts of these are also given.

1. J. K. Balkwill, "Mechanical Elements Operating in Sodium and Other Alkali Metals, Vol I, Literature Survey, "Liquid Metal Engineering Center, LMEC68-5 (December 31, 1968)

A serach was made of literature reporting information published since 1950 on mechanical devices with rubbing surfaces operating in alkali metals. Sodium environments a re emphasized, with data also included from potassium, NaK, and lithium experiments. The characteristics of potentially useful materials that are important in liquid metal applications are discussed. Material compatibility and friction/wear testing programs conducted since 1950 are described. Experimental and operating experience with full-size components is presented. This survey includes most of the reports written prior to 1969.

2. W. H. Roberts, "Friction and Wear Behavior of Sliding Bearing Materials in Sodium Environments at Temperatures Up to $600^{\circ} \mathrm{C}, "$ U. K. A. E. A. , Risley, TRG Report 1269(R), (1966)

Friction and wear data are presented for a selection of molybdenum, tungsten, and chromium alloys, over the temperature range of 200 to $600^{\circ} \mathrm{C}$, for two sodium environments: molten metal, containing 5 ppm of oxygen impurity, and pure argon containing sodium vapor. Some comparisons are made with gaseous environments of pure argon and carbon dioxide. An indication is given of the effect of increasing the oxygen content from about 5 to $80 \mathrm{ppm}$. Chemisorbed, double-oxide films, formed by reaction of the molybdenum, tungsten, chromium, and, possibly, iron constituents of the alloys with the sodium environment, play a significant role in providing boundary lubrication in high-temperature sodium. The effectiveness of the lubrication provided by such films is a function of the specific nature of the sodium environment, temperature, and time at temperature. Another source of boundary lubrication considered to have been operative were compounds of constituents of the alloys whose efficacy does not primarily depend on reaction with sodium. 
3. F. A. Smith, E. S. Sowa, E. I. Kimont, and C. R. Sutton, $1650^{\circ} \mathrm{C}$ Sodium Free-Surface, Stress and Wear Effects on Reactor-Component Metals," Argonne National Laboratory, IAEA Paper SM-85/22 (1966)*

A Falex wear tester was modified for $650^{\circ} \mathrm{C}$ sodium. Carbon steel-Type 304 SS and Stellite No. 19-Carboloy 78B were investigated. The axial hardness profile of a Type 304 SS rod partially immersed in sodium was measured. Photos of the rod microstructure are shown. The electrical resistivity of Type 304 SS and Type 347 SS tubing was measured at 900 to $1400^{\circ} \mathrm{F}$ in air, vacuum, liquid sodium, and sodium vapor, both before and after a modified Strauss test.

4. A. W. J. DeGee, C. P. L. Commissaris, E. G. Chirer, and A. J. Bogers, "Equipment for the Study of Wear Under Conditions of Oscillatory RelativMotion in Liquid Sodium, "Metal Research Institute, TNO, DELFT, The Netherlands, IAEA Paper SM-85/39 (1966)*

Equipment for the study of wear in liquid sodium under conditions of oscillatory relative motion of small amplitude/fretting/is described in detail. With this equipment experiments can be performed at temperatures up to $750^{\circ} \mathrm{C}$ in sodium with controlled oxygen content. The following vibration patterns may be applied: (1) torsional vibration in the plane of contact of two test specimens, (2) oscillatory motion normal to the plane of contact, and (3) any combination of (1) and (2). With this equipment preliminary experiments have been performed with austenitic stainless steel X8CrNiMoVNb 16/13, at different levels of temperature and oxygen content. Adhesion and subsequent metal transfer were found to occur irrespective of sodium temperature and oxygen content. However, only at a high oxide content of the sodium does this lead to appreciable volume wear. If the oxide content is low, surface deterioration does not lead to the formation of wear debris. There is some indication that the temperature of the sodium hardly influences the wear process.

5. E. Wild, K. Mack, and H. Hoffman, "The Wear Behavior of Steels and Alloys in Liquid Sodium, "Karlsruhe Nuclear Research Center, United States - Euratom Fast Reactor Exchange Program, EURFNR-696 (April 1969)

Knowledge of the wear behavior of pairs of materials is necessary in the selection of materials for bearings and bushings for the components of sodium-cooled reactors. This was examined in the present work for 36 different combinations of materials under the same operating conditions. The model geometry used consisted of three cylindrical samples which performed oscillating movements on a disk. The investigations were carried out in a test rig with a continuous sodium flow. The more favorable combinations of materials are to be tested in more detailed parameter studies, with special attention to the influence of temperature, stress, sliding velocity, and the oxide content of the sodium.

LMEC - 70- 10

172 
6. F. S. Sowa, K. C. Tsao, C. Fiala, and C. J. Divona, "Some Observations on Phenomena Affecting Wear of Bearing Materials in Sliding Contact in Sodium and Argon at Temperatures up to $1200^{\circ} \mathrm{F}$, "Argonne National Laboratory, Wisconsin University, ANL-7580 (July 1969)

V-blocks of Type 304 SS, Clarite T-1 tool steel, Stellite 19B and molybdenum were tested in a modified Falex machine against a rotating Carboloy $78 \mathrm{~B}$ shaft in static sodium and in argon at 300 , $500,700,900$, and $1200^{\circ} \mathrm{F}$. Tests lasted 2 hours at each temperature for a total of 10 hours per test. Volumetric wear of the $\mathrm{V}$-blocks was calculated from LVDT measurements of V-block movement during the test, and results are given as volumetric wear vs time. Recordings of drive-motor current input show a correlation between time variation in friction coefficient in regions of abnormal wear, but the absolute magnitude of the friction coefficient had no relationship to wear. The tool steel and Stellite showed negligible wear in sodium, the stainless wear rate was high above $700^{\circ} \mathrm{F}$, and the molybdenum wear rate was low at $700^{\circ} \mathrm{F}$ and above. In argon, the tool steel galled seriously at $1200^{\circ} \mathrm{F}$, Stellite showed high rates at $700^{\circ} \mathrm{F}$ and below but low rates at 900 and $1200^{\circ} \mathrm{F}$, and molybdenum high rates at 300 and $500^{\circ} \mathrm{F}$, low rates at 700 and $900^{\circ} \mathrm{F}$ as double oxide formed, high rates at $1200^{\circ} \mathrm{F}$ as oxide wore off.

7. D. J. Kniley, W. J. Carlson, E. Ferguson, and O. G. Jenkins, "Mechanical Elements Operating in Sodium and Other Alkali Metals, Vol II, Experience Survey, "Liquid Metal Engineering Center, LMEC-68-5 (June 1, 1970)

The operating history of sodium service mechanisms used in the following sodium-cooled reactors is presented: the Sodium Reactor Experiment, the Experimental Breeder Reactor II, the Enrico Fermi Atomic Power Plant, and the Hallam Nuclear Power Facility. Included are mechanism component design characteristics, operating conditions, their operability and maintainability, and the history of component malfunctions with the subsequent repairs or modifications required.

*These IACA papers have been published in the book Alkali Metal Coolants, International Atomic Energy Agency, Vienna, 1967. 